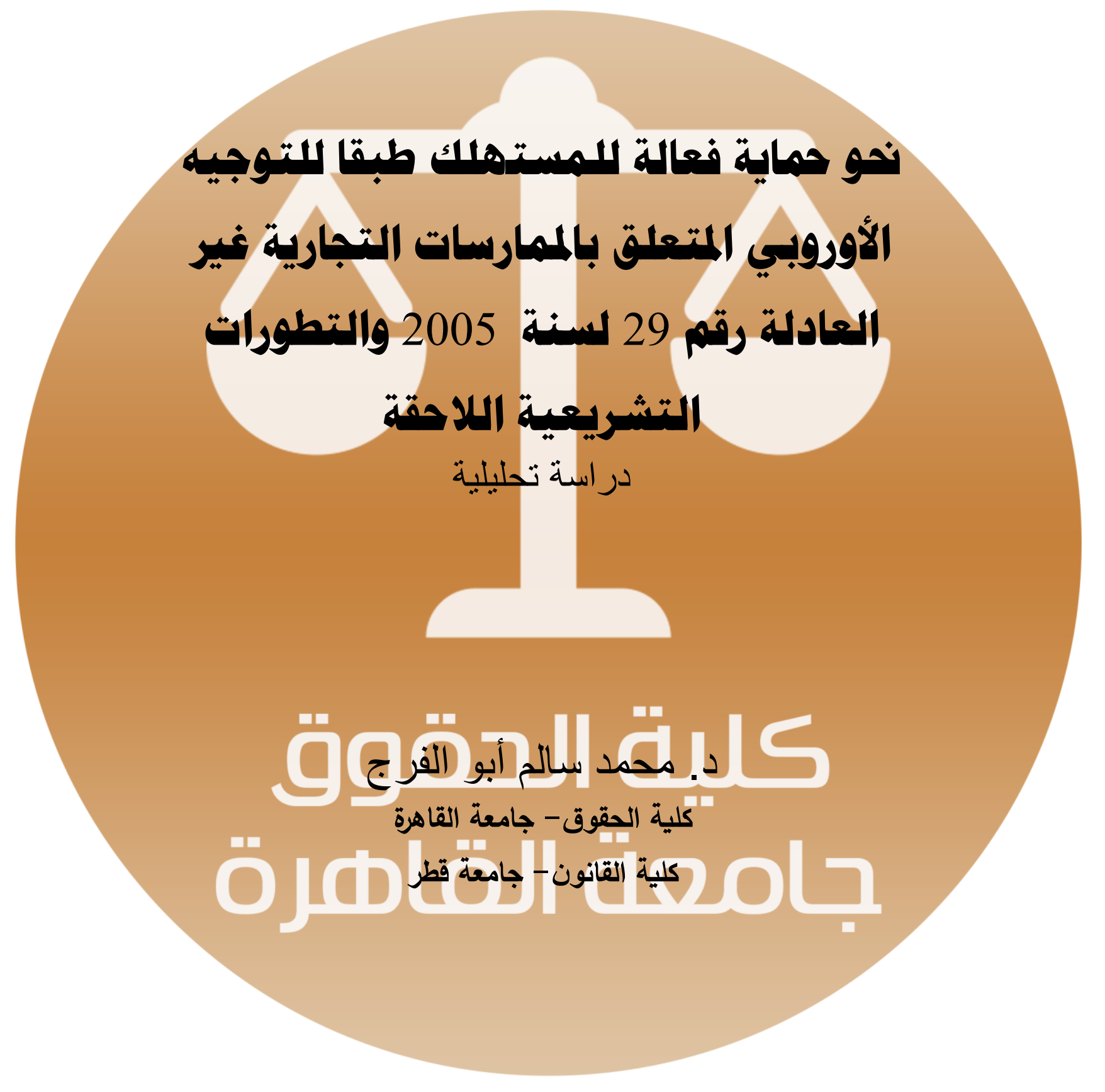


416 مجلة القانون والاقتصاد - ملحق خاص بمناسبة مرور مائة وخمسين عام

على إنثاء كلية الحقوق - جامعة القاهرة - العدد (الثانى والتسعون)

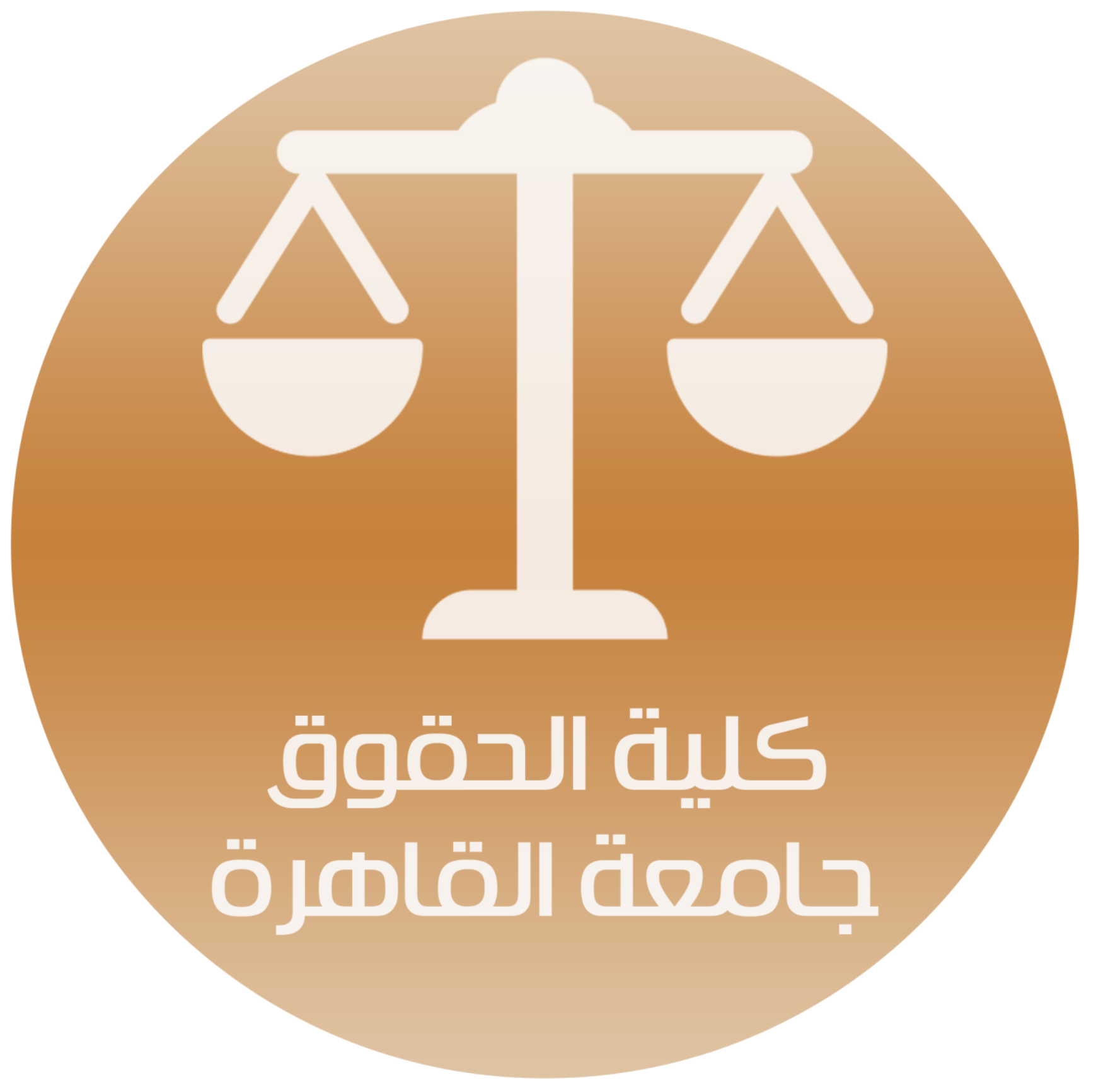




\section{مفص الدراسة}

صدر التوجيه الأوروبـي المتعلق بالممارسـات التجاربـة غير العادلـة (توجيه

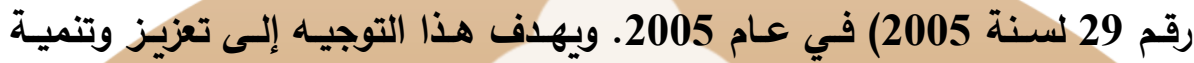

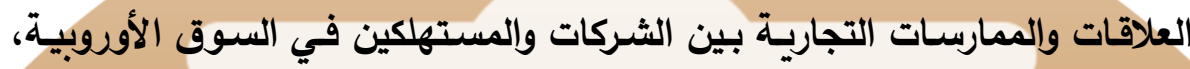

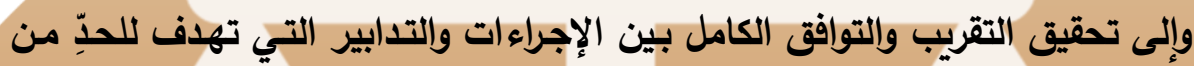

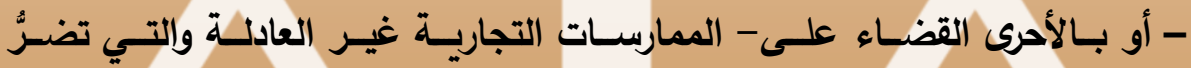

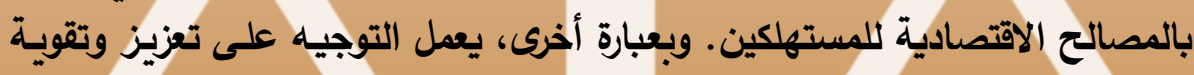

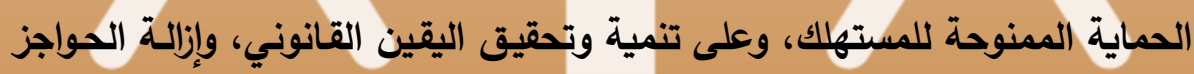

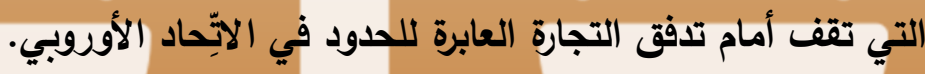
إن الهـدف الـرئيس لهـذه الدراسـة هـو تحليـل نصـوص التوجيـه الأوروبـي

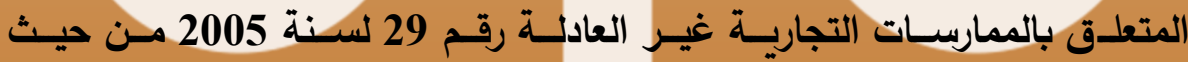

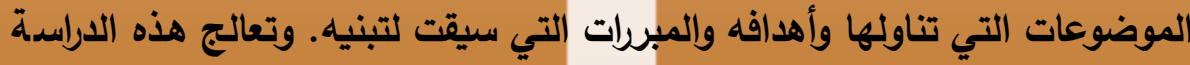

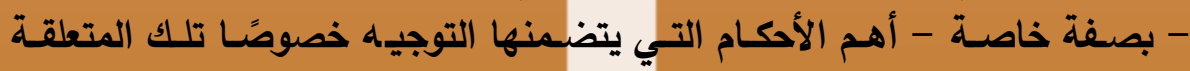

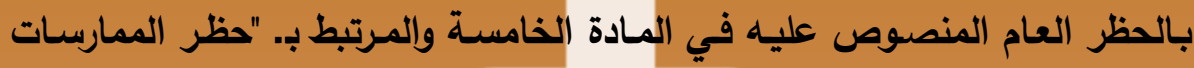

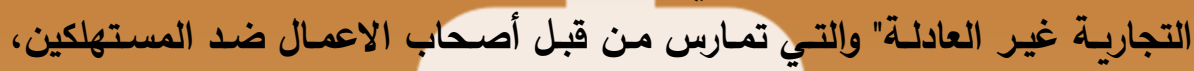

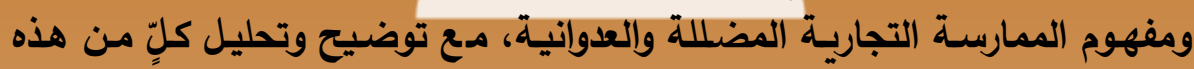

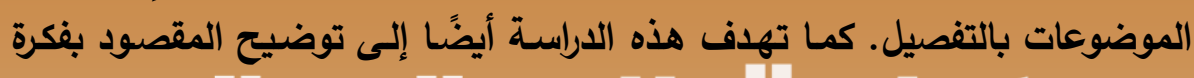

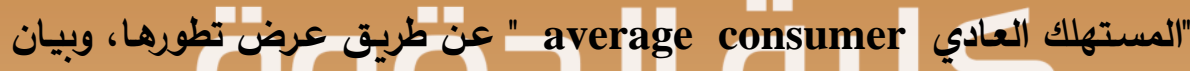

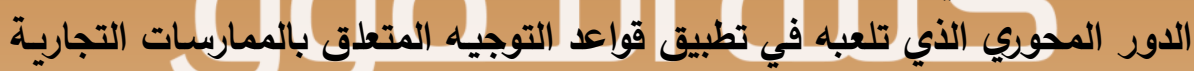

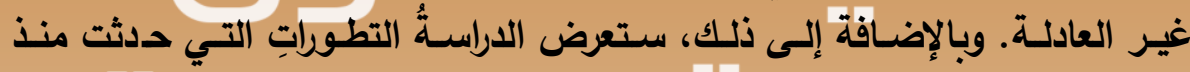

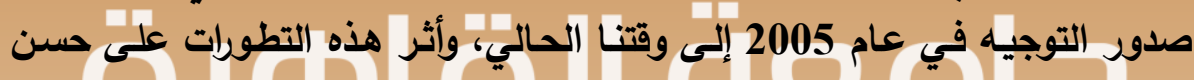

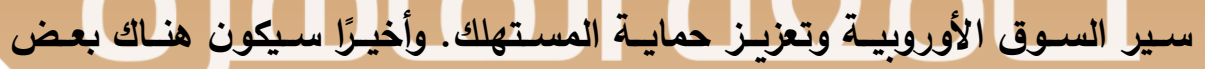

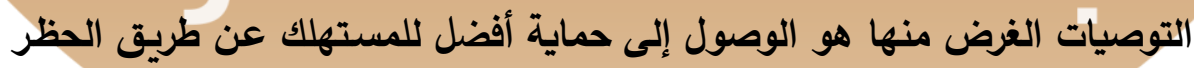

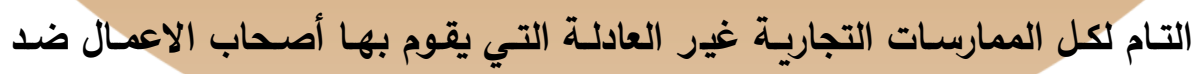

وبنـاءً على ذلك سـتكون خطـة هذه الدراســة في فصلين تسـبقهما مقدمـة 
مجلة القانون والاقتصاد - ملحق خاص بمناسبة مرور مائة وخمسين عام

على إنثاء كلية الحقوق - جامعة القاهرة - العدد (الثانى والتسعون)

ومطلب تمهيدي، وتعقبهمـا خاتمـة. يتــاول الفصـل الأول من هذه الدراسـة نطاق

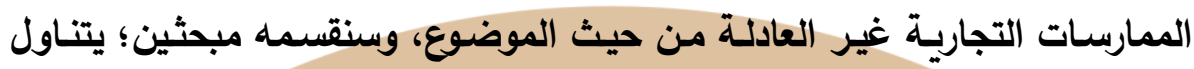

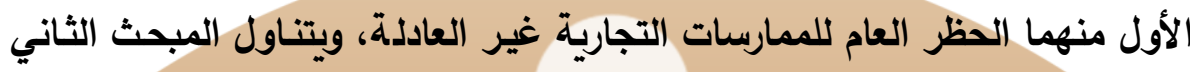

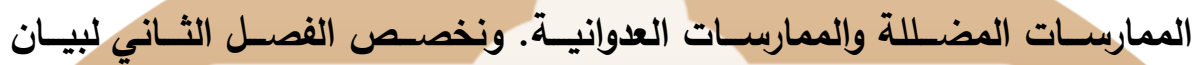

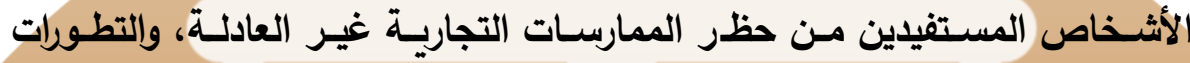

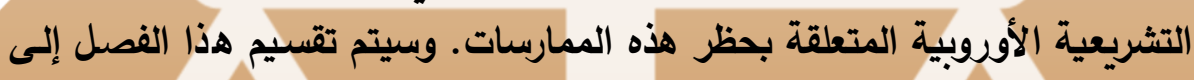

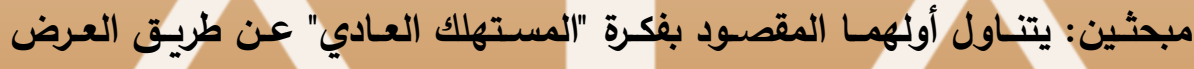

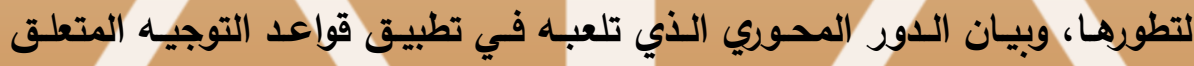

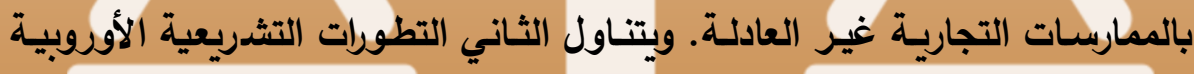

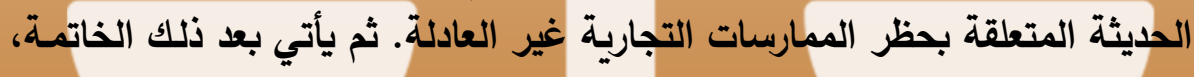

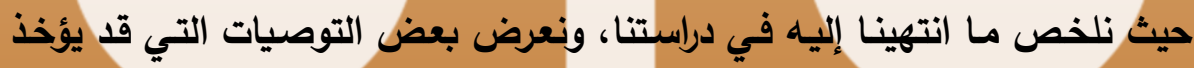

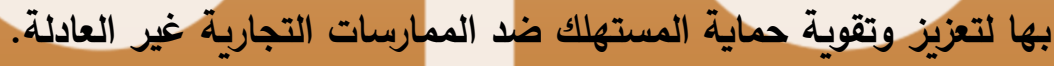
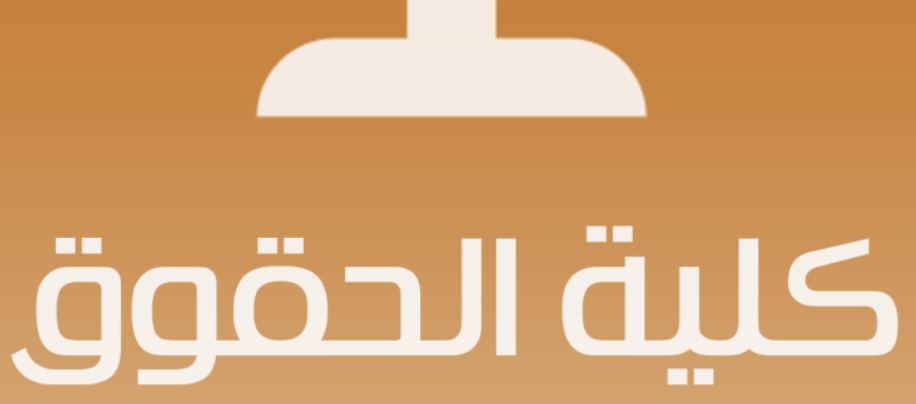
حامهة القالقمرة 


\section{هقدمة}

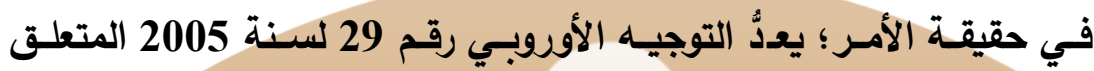

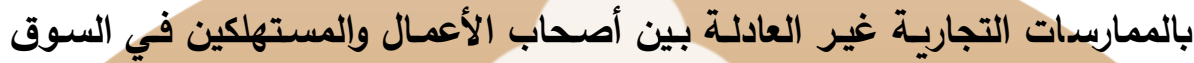

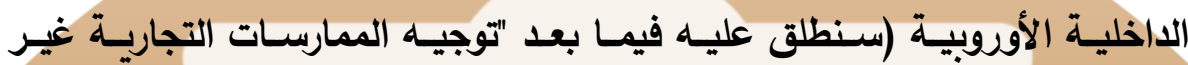
Directive 2005/29/EC of the European Parliament 1 and of the Council of 11 May 2005 concerning unfair business-to-consumer commercial practices in the internal

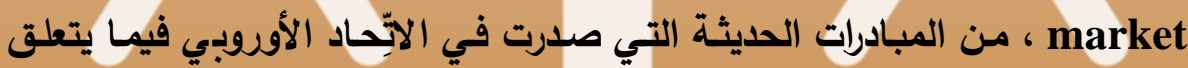

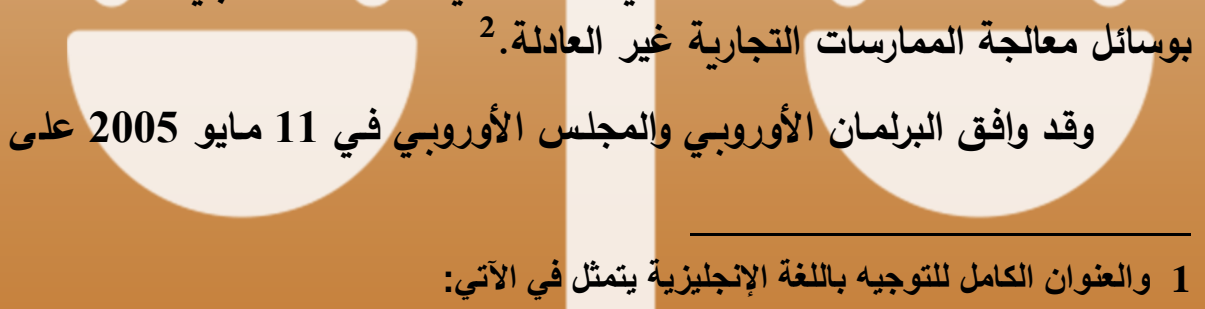

"Directive 2005/29/EC of the European Parliament and of the Council of 11 May 2005 concerning unfair business-to-consumer commercial practices in the internal market and amending Council Directive 84/450/EEC, Directives 97/7/EC, 98/27/EC and 2002/65/EC of the European Parliament and of the Council and Regulation (EC) No 2006/2004 of the European Parliament and of the Council ('Unfair Commercial Practices Directive')"

http://eur-

ويمكن الاطِّلاع على نسخة التوجيهه على موقع الآتِّداد الأوروبي على شبكة الإنترنت: lex.europa.eu/LexUriServ/LexUriServ.do?uri=OJ:L:2005:149:0022:0 039:en:PDF

Nathan Reilly, 'The Role of Traders in the Enforcement of the Unfair Commercial Practices Directive: A New Unfair Competition Law for Ireland' (2009) 31 Dublin University Law Journal, pp. 100-126, at 112.

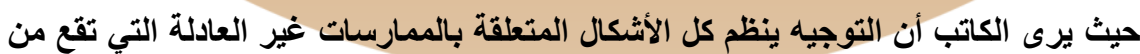

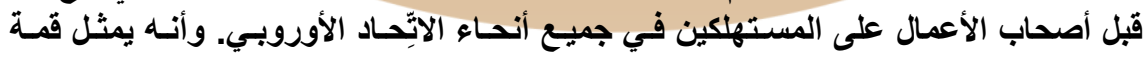
مجهودات الاتِّحاد الأوروبي في مجال تشريعات حماية المستهيتك. 
مجلة القانون والاقتصاد - ملحق خاص بمناسبة مرور مائة وخمسين عام

على إنثاء كلية الحقوق - جامعة القاهرة - العدد (الثانى والتسعون)

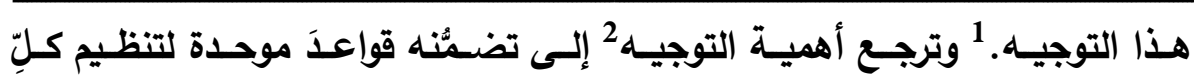

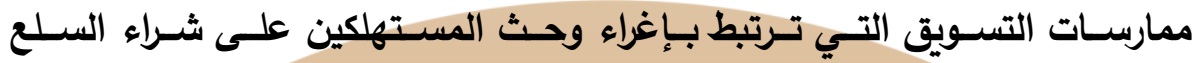

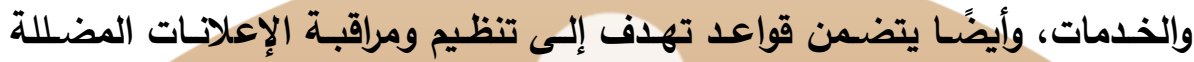

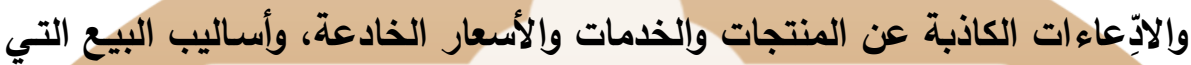
تتمُّ تحت ضغطٍ عالٍٍ على المستهلك. 3

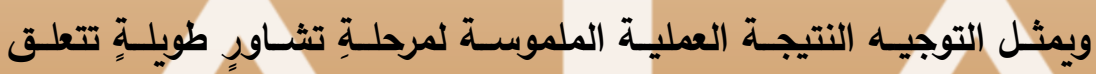

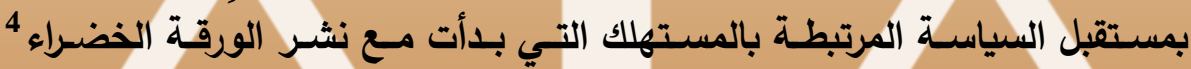

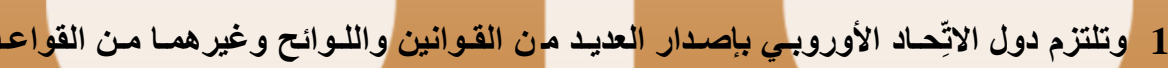

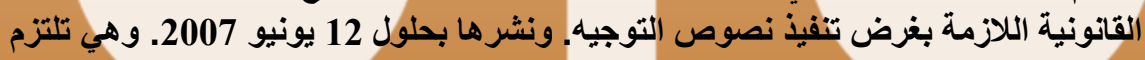

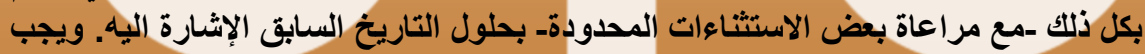

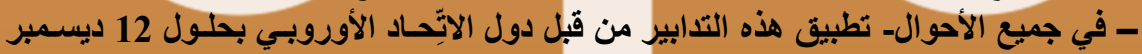

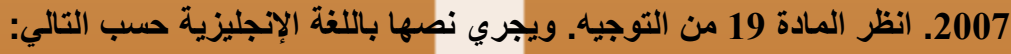

"Member States shall adopt and publish the laws, regulations and administrative provisions necessary to comply with this Directive by 12 June 2007.... They shall apply those measures by 12 December 2007...."

2 للمزيد من التفصيل عن الخلفية التاريخية لمشروع التوجيه، أنظر:

Matthias Leistner, 'Unfair Competition or Consumer Protection? The Commission's Unfair Commercial Practices Proposal 2003' (2003-2004) 6 Cambridge Y.B. Eur. Legal Stud. p. 141.

Hugh Collins, 'Harmonisation by Example: European Law against Unfair Commercial Practices' (2010) 73 Modern Law Review, pp. 89118.

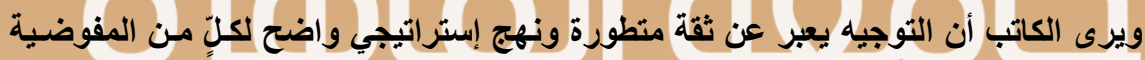

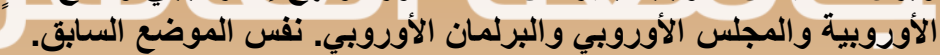

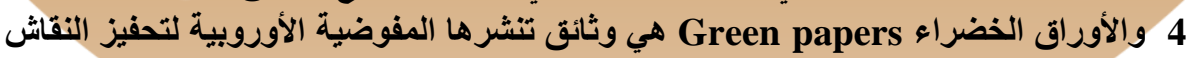

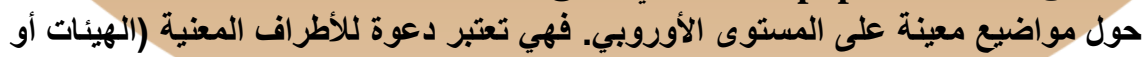

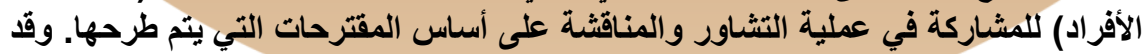

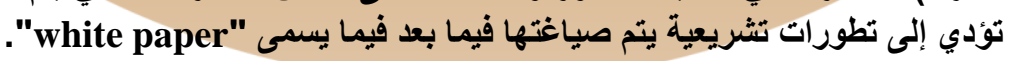

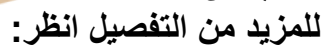

http://ec.europa.eu/green-papers/index_en.htm 
green paper

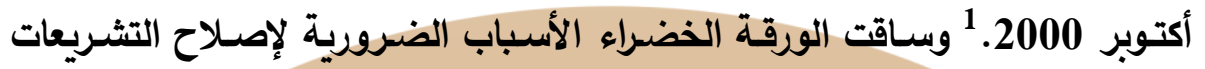

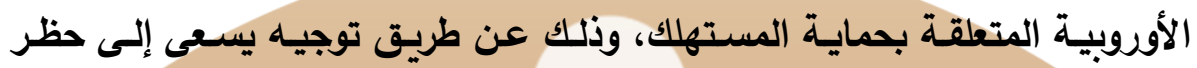

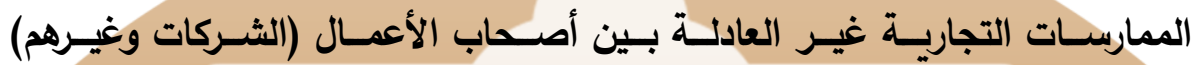

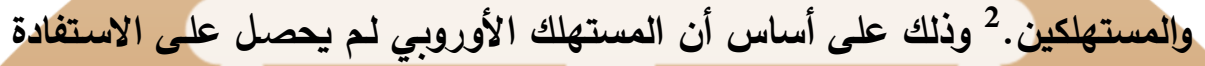

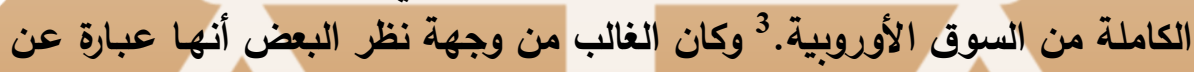

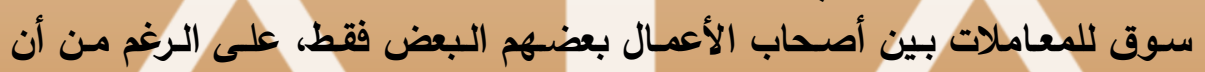

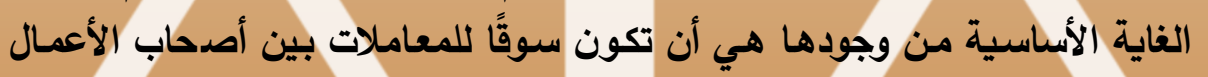

تم الاطّّلاع على الموقع بتاريخ 31 مسايو 2016. والأوراق البيضـاء (white papers) هي

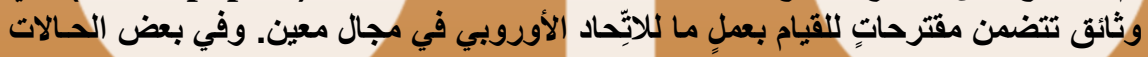

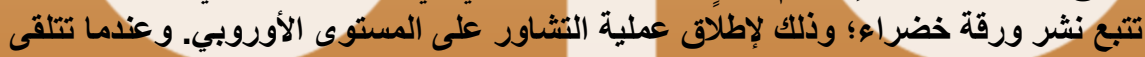

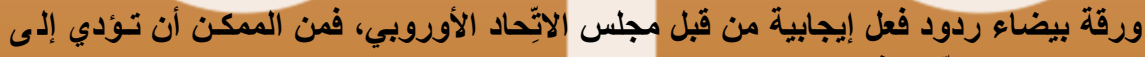

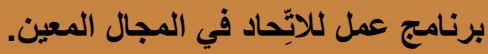

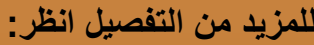

http://ec.europa.eu/white-papers/index en.htm

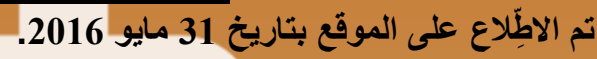

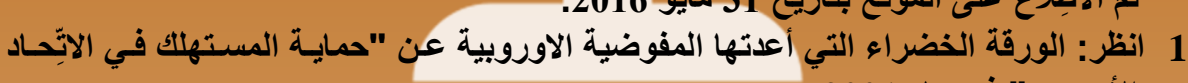

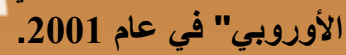

Commission Green Paper on European Union Consumer Protection, COM (200 I) 531 final (Brussels, October 2, 2001). Available at: http://eur-lex.europa.eu/legalcontent/EN/TXT/PDF/?uri=CELEX:52001DC0531\&from=EN

\section{تم الاطِّلاع بتَاريخ 31 مايو 2016. و انظّر أيضًا:}

Giuseppe B. Abbamonte, 'The Unfair Commercial Practices Directive: An Example of the New European Consumer Protection Approach'(2006) 12 Columbia Journal of European Law, pp.695-712, at 696; Matthias Leistner, op. cit., p.142 et seq.; and Thomas Wilhelmsson, 'Harmonizing Unfair Commercial Practices Law: The Cultural and Social Dimensions' (2006) 44 (3) Osgoode Hall Law Journal, pp. 461-500, at pp.474 et seq.

Abbamonte, op. cit., p. 696.

$$
2 \text { انظر: الورقة الخضراء، المرجع السابق، ص 7. وانظر أيضًا: }
$$


مجلة القانون والاقتصاد - ملحق خاص بمناسبة مرور مائة وخمسين عام

على إنثاء كلية الحقوق - جامعة القاهرة - العدد (الثانى والتسعون)

والمستهلكين. 1 وقد أشير إلى أن هذه الغاية قد أصبحت بعيدةً عن التحقق. ويمكن

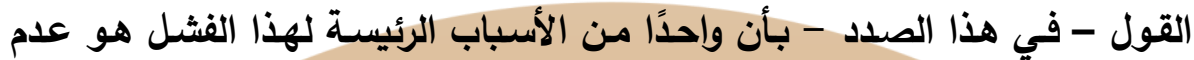

توافر ثقة للمستهاك في المعاملات العابرة للحدود.2 وقد أشـارت المفوضية - في هذه الورقة الخضراء - إلى الاختلاف الواسـع

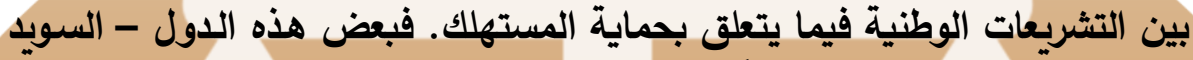

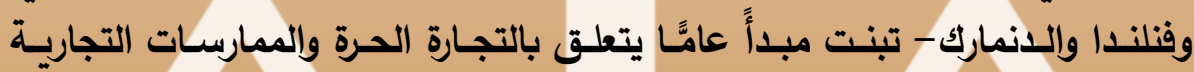

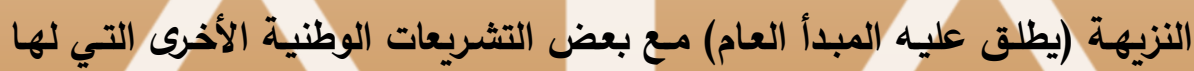

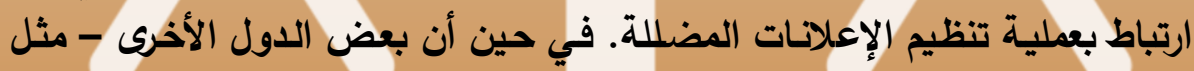

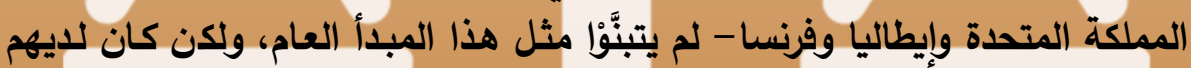
تشربعاتُ خاصةٌ تنظم هذه وإنطاليا وفرنسا الموضوعات. 3

وبناءً على ذلك، وسعيًا إلى تحقيق التقارب الكامل بين الإجراءات والتـدابير

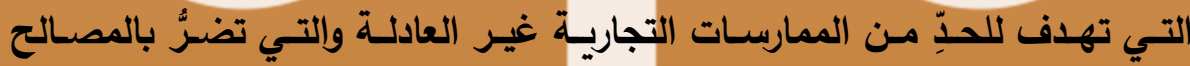

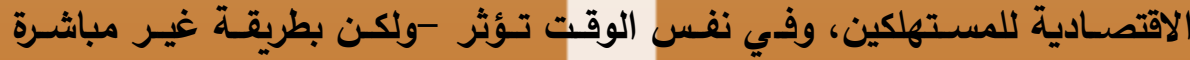

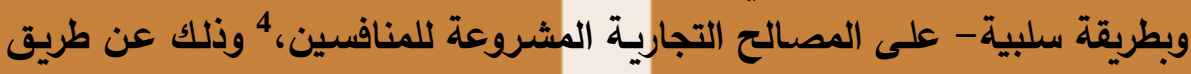

1 للمزيد من التفصيل عن التجارة العادلة وحماية المستهلك من الممارسات التجارية غير العادلة Bert Keirsbilck, The New European Law of Unfair Commercial Practices and Competition Law (Oxford: Hart Publishing, 2011), p. 25 et seq.

Abbamonte, op. cit., p. 696.

3 انظر: الورقة الخضراء، المرجع السابق، ص 9.

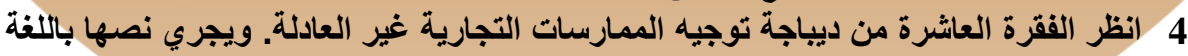

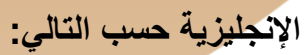

"This Directive therefore approximates the laws of the Member States on unfair commercial practices, including unfair advertising, which directly harm consumers' economic interests and thereby indirectly harm the economic interests of legitimate competitors...." 
إزالة العوائق التي تقف في سبيل تحقيق هذا التقارب،1 فقد ارتأى الآِّحاد الأوروبي

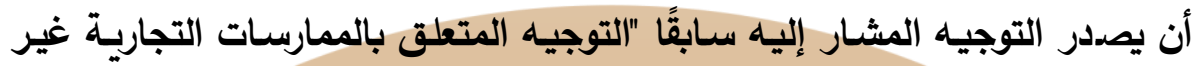

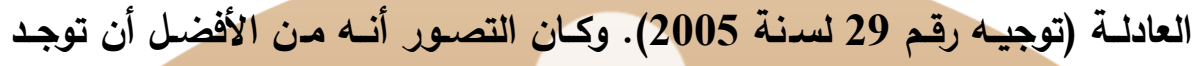

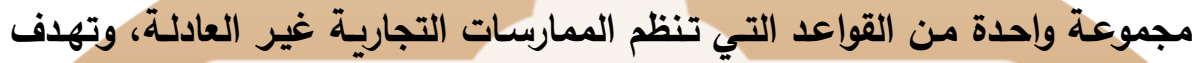

1 انظر المادة الأولى مـن توجيه الممارسـات التجاريـة غير العادلـة التـي يجري نصهـا باللغـة الإنجليزية على النحو التالي:

"The purpose of this Directive is to contribute to the proper functioning of the internal market and achieve a high level of consumer protection by approximating the laws, regulations and administrative provisions of the Member States on unfair commercial practices harming consumers' economic interests."

و انظر أيضًا الفقرة السادسة من ديباجـة توجيـه الممارســات التجاريـة غير العادلـة. ويجري نصها باللغة الإنجليزية حسب التخالية من دياجة

"This Directive therefore approximates the laws of the Member States on unfair commercial practices, including unfair advertising, which directly harm consumers' economic interests...."

و انظر أيضًا الفقرة الخامسـة مـن التوجيـه التـي يجري نصـها باللغـة الإجليزيـة على النـو

"... such obstacles should be eliminated. These obstacles can only be eliminated by establishing uniform rules at Community level which establish a high level of consumer protection and by clarifying certain legal concepts at Community level to the extent necessary for the proper functioning of the internal market and to meet the requirement of legal certainty."

وانظر أيضًا الفقرة الثانية عشرة من التوجيه التي يجري نصها باللغة الإنجليزية على النحو التالي: - (2)

"Harmonisation will considerably increase legal certainty for both consumers and business. Both consumers and business will be able to rely on a single regulatory framework based on clearly defined legal concepts regulating all aspects of unfair commercial practices across the EU. The effect will be to eliminate the barriers stemming from the fragmentation of the rules on unfair commercial practices harming consumer economic interests and to enable the internal market to be achieved in this area." 
مجلة القانون والاقتصاد - ملحق خاص بمناسبة مرور مائة وخمسين عام

على إنثاء كلية الحقوق - جامعة القاهرة - العدد (الثانى والتسعون)

أساسًا إلى تنمية حقيقية في العلاقات والممارسات التجارية بين الثركات وأصحاب

الأعمال بصفة عامة والمستهلكين في السوق الأوروبية. 1

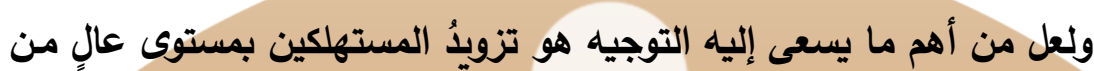

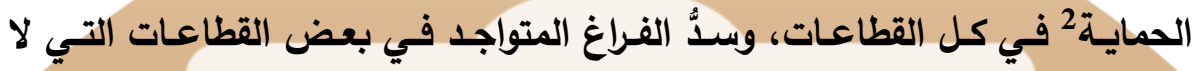

تتناولها بعض قوانين الآتِّاد الأوروبي الخاصـة.

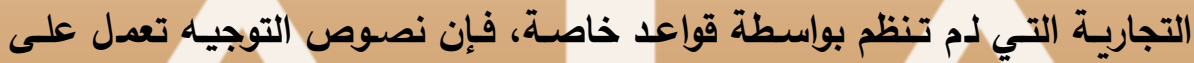

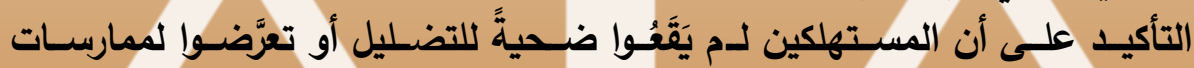

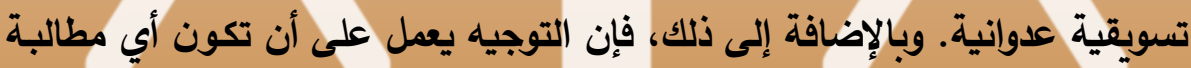

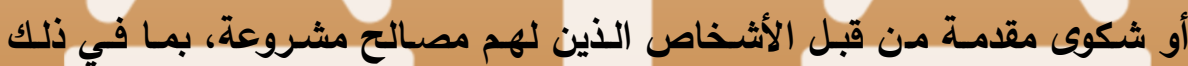

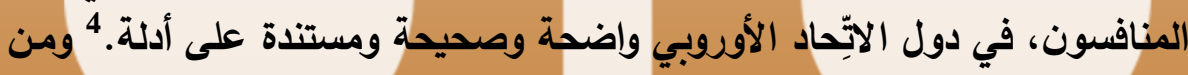

Abbamonte, op. cit., pp. 698-9.

2 وتجدر الإشارة هنا إلى أن التوجيه لم يوضح لنا مـا يعدُ "مستوى عاليًا من الحماية للمستهلك"

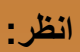

B. B. Duivenvoorde, The Consumer Benchmarks in the Unfair Commercial Practices Directive (Switzerland, Springer International Publishing, 2015) p. 16; and C.M.D.S. Pavillon, 'The Interplay Between The Unfair Commercial Practices Directive and Codes of Conduct' (2012) 5 (4) Erasmus Law Review, pp. 267-288, at 267.

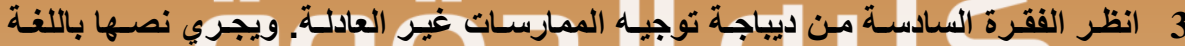

“...This Directive accordingly applies only in so far as there are no specific Community law provisions regulating specific aspects of unfair commercial practices, such as information requirements and rules on the way the information is presented to the consumer. It provides protection for consumers where there is no specific sectoral legislation at Community level and prohibits traders from creating a false impression of the nature of products...."

4 انظر الفقرة الواحدة والعشرين من ديباجة توجيه الممارسات غير العادلة. ويجري نصها باللغة

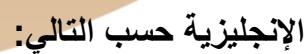

"Persons or organisations regarded under national law as having a legitimate interest in the matter must have legal remedies for 
ثم يحرص التوجيه على أن تكون قراراتُ المستهلكين قائمسةً على علم تام وأنهم كانوا يتمتعون بخيارات حقيقية. 1

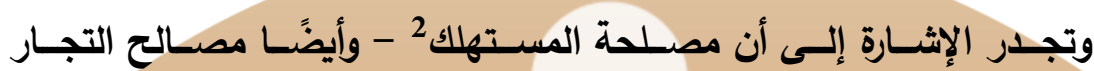

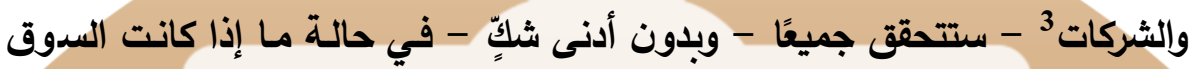

initiating proceedings against unfair commercial practices, either before a court or before an administrative authority which is competent to decide upon complaints or to initiate appropriate legal proceedings. While it is for national law to determine the burden of proof, it is appropriate to enable courts and administrative authorities to require traders to produce evidence as to the accuracy of factual claims they have made."

وانظر أيضًا المـادة الحاديـة عشرة من التوجيهه التي سبيتم تناولهـا بالتفصيل في المطلب 1 التمهيدي. 1 انظر الجملة الأخيرة من الفقرة السادسة من ديباجة التوجيه. ويجري نصها باللفـة الإنجليزيـة على النحو التالي:

“...this Directive does not affect accepted advertising and marketing practices, such as legitimate product placement, brand differentiation or the offering of incentives which may legitimately affect consumers' perceptions of products and influence their behaviour without impairing the consumer's ability to make an informed decision."

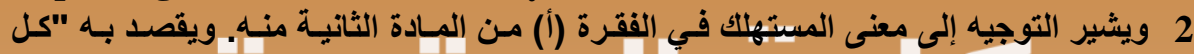

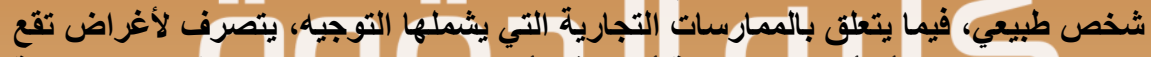

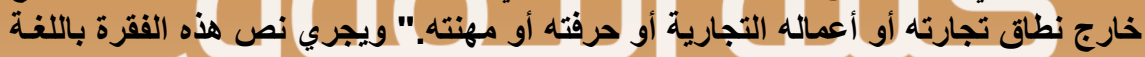

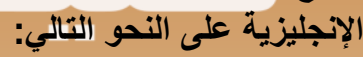

"consumer' means any natural person who, in commercial practices covered by this Directive, is acting for purposes which are outside his trade, business, craft or profession."

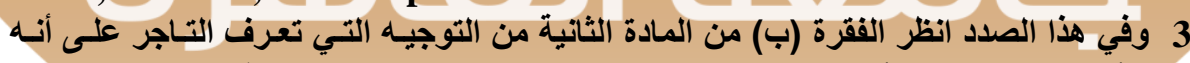

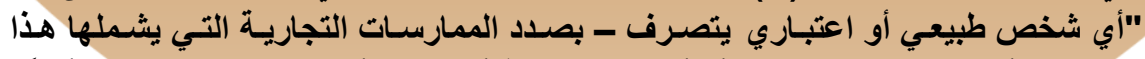

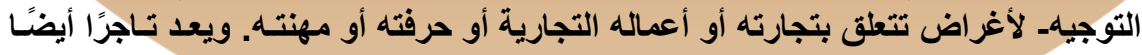

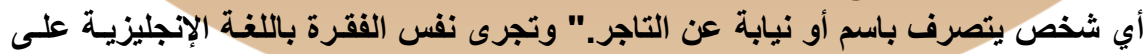

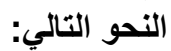

"'trader' means any natural or legal person who, in commercial practices covered by this Directive, is acting for purposes relating to 
مجلة القانون والاقتصاد - ملحق خاص بمناسبة مرور مائة وخمسين عام

على إنثاء كلية الحقوق - جامعة القاهرة - العدد (الثانى والتسعون)

الأوبية تعمل وتُدَار بطريقة صحيحة. ويتطلب التسيير الصحيح والإدارة المـلانمـة

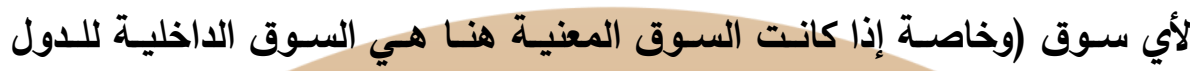

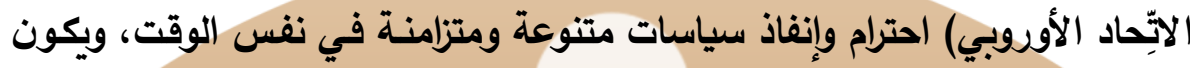

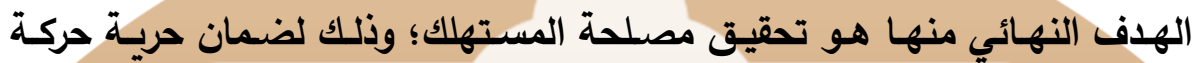

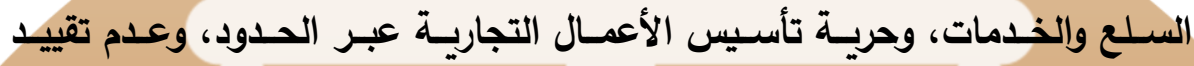

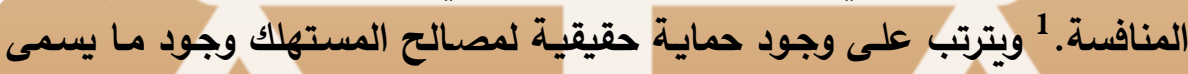

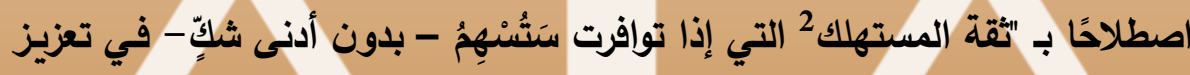
السوق الأوروبية وتحسين عملياتها. 3

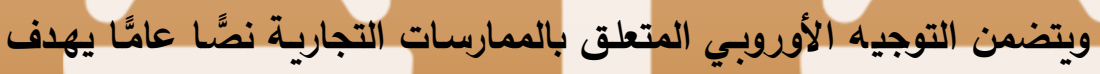

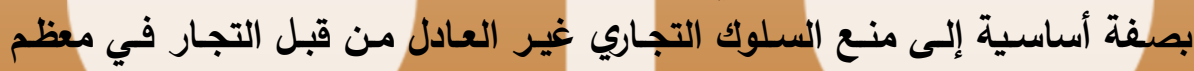

his trade, business, craft or profession and anyone acting in the name of or on behalf of a trader."

1 انظر على سبيل المثال الفقرة الثانية من ديباجة توجيه الممارسات غير العادلة. ويجري نصها باللغة الإنجليزية حسب التثال الفرة

"In accordance with Article 14(2) of the Treaty, the internal market comprises an area without internal frontiers in which the free movement of goods and services and freedom of establishment are ensured. The development of fair commercial practices within the area without internal frontiers is vital for the promotion of the development of cross border activities."

\section{وانظر أيضًا المادة الحادية عشرة من التوجيه.}

\section{2}

T Wilhelmsson, 'The Abuse of the 'Confident Consumer' as a Justification for EC Consumer Law' (2004) 27 (3) Journal of Consumer Policy, pp. 317-337, at 319 et seq.

3 انظر الفقرة الرابعة من ديباجة توجيه الممارسات غير العادلة. ويجري نصها باللغة الإنجليزية

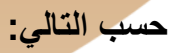

"...Such barriers also make consumers uncertain of their rights and undermine their confidence in the internal market...."

و وانظر أيضا المادة الحادية عشرة من التوجيـه. وسنتناول هذه المـادة بالثـرح في المطلب 
الظروف. 1 وتجدر الإشارة إلى أن قواعد التوجيه الموضوعية - التي تحدد ماهية

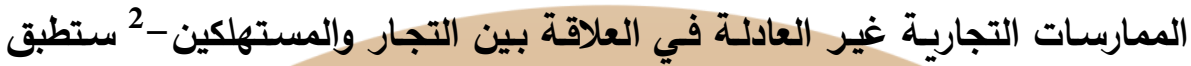

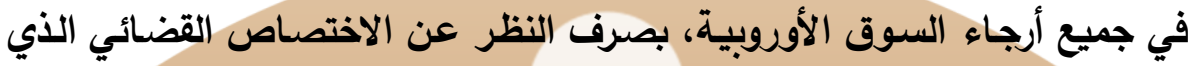

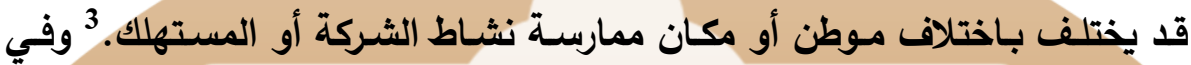

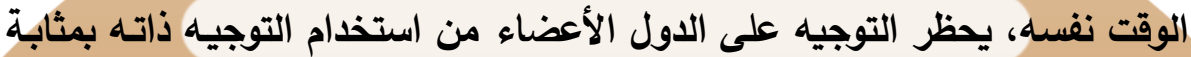
عقبة أمام حربـة حركة البضائع والخدمات. 4 وتجدر الإثارة إلى أن توجيه الممارسات التجارية غير العادلة قد منح الدول

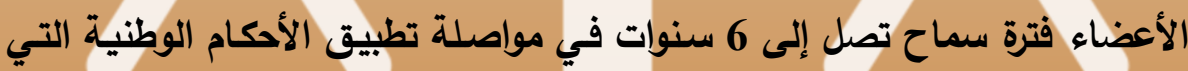

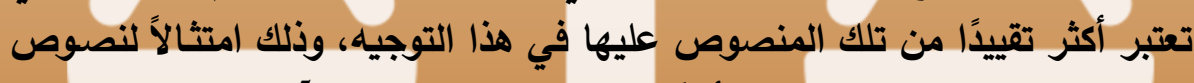

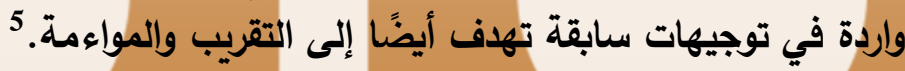

1 انظر المادة الخامسة من التوجيه. وسنتناول شرح هذه المادة بالتفصيل في الفصل الأول مـن هذه الدراسة.

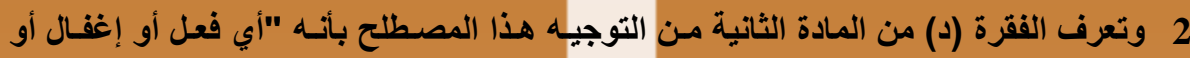

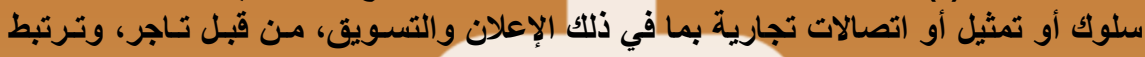

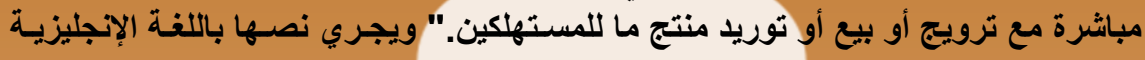

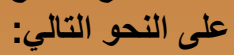

"'business-to-consumer commercial practices' (hereinafter also referred to as commercial practices) means any act, omission, course of conduct or representation, commercial communication including advertising and marketing, by a trader, directly connected with the promotion, sale or supply of a product to consumers."

3 انظر المادة العاشرة من التوجيه. ويجري نص هذه المادة باللفة الإنجليزية على النحو التالي:

"These facilities shall be available regardless of whether the consumers affected are in the territory of the Member State where the trader is located or in another Member State."

4 انظر المادة الرابعة من التوجيه. ويجري نص هذه المادة باللغة الإنجليزية على النحو التالي:

"Member States shall neither restrict the freedom to provide services nor restrict the free movement of goods for reasons falling within the field approximated by this Directive."

5 وقد يمتد الوقت المتاح لهذه الدول إلى أكثر من ذلك، انظر الفقرة الخامسـة مـن المـادة الثالثة.

$$
\text { ويجري نصها على النحو التالي : }
$$


مجلة القانون والاقتصاد - ملحق خاص بمناسبة مرور مائة وخمسين عام

على إنثاء كلية الحقوق - جامعة القاهرة - العدد (الثانى والتسعون)

ونظرًا لأهميـة هذه الدراسـة، فإنها سـتقوم بعرض المشكلة ومحاولـة إيجـاد

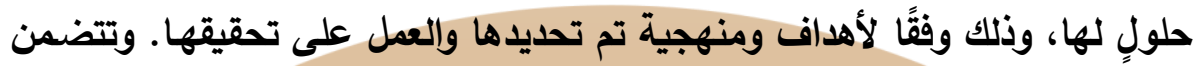

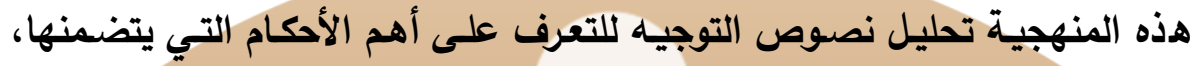

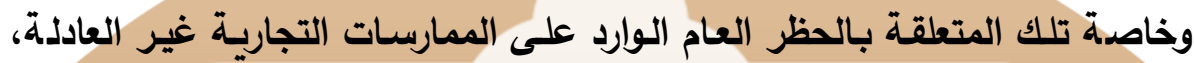

وتلك المتعلقة بأحكام الممارسات المضللة والعدائية.

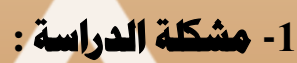

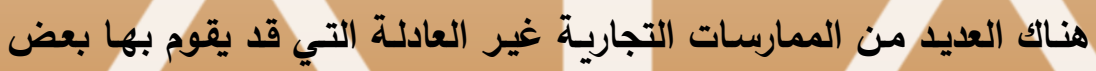

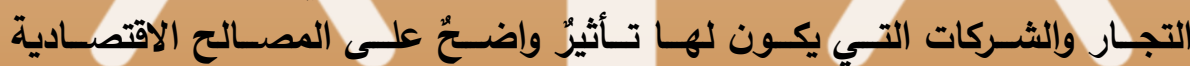

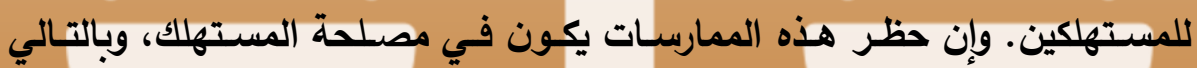

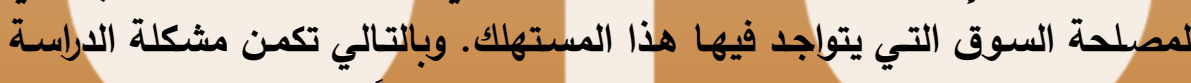

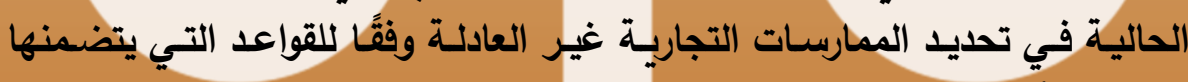

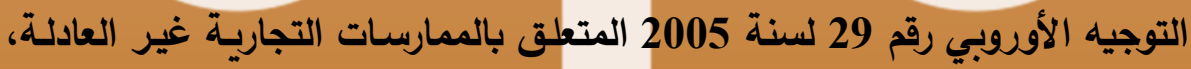

"For a period of six years from 12 June 2007, Member States shall be able to continue to apply national provisions within the field approximated by this Directive which are more restrictive or prescriptive than this Directive and which implement directives containing minimum harmonization clauses... The review referred to in Article 18 may, if considered appropriate, include a proposal to prolong this derogation for a further limited period.."

وانظر ايضًا المادة الثامنة عشرة من التوجيه التي يجري نصها باللغة الإنجليزية على النحو

"By 12 June 2011 the Commission shall submit to the European Parliament and the Council a comprehensive report on the application of this Directive, in particular of Articles 3(9) and 4 and Annex I, on the scope for further harmonisation and simplification of Community law relating to consumer protection, and, having regard to Article 3(5), on any measures that need to be taken at Community level to ensure that appropriate levels of consumer protection are maintained. The report shall be accompanied, if necessary, by a proposal to revise this Directive or other relevant parts of Community law." 
ومحاولة توضيح أثر حظر هذه الممارسات على تحقيق مصلحة المستهلك، وزيـادة

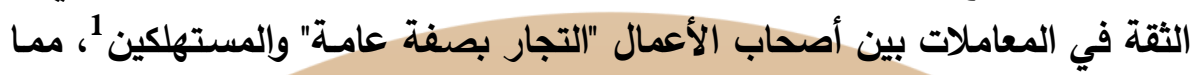

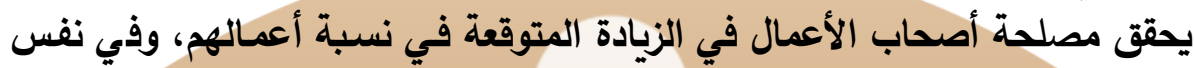

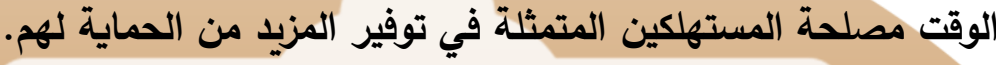

2- أهداف الدوراسة: تهاف هذه الدراسة إلى تحقيق ما يلي: دراسة المبررات التي أدت إلى إصدار هذا التوجيه. الكشـف عن نطـاق تطبيق هذا التوجيـه والمصـطاحات المسـخدمة فيـه وإنفاذه.

بيان نطاق الممارسـات التجاريـة غير العادلة. وبعبارة أخرى، يمكن القول

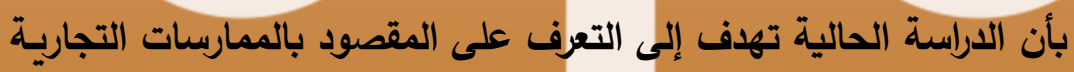
غير العادلة. - - عليل الحظر العام المفروض على الممارسات التجارية غير العادلة. - - تحليل المقصود بالممارسات التجارية المضللة. - - تحليل المقصود بالممارسات التجاريـة العدوانية. - - دراستة المقصود بالمستهاك في نطاق التوجيه المعذي. وبعبارة أخرى: هل يكتفى بفكرة "المستهلك العادي" فقط في هذا الشأن؟ وما الدور الذي يمكن أن يسهم باه هذا التحديد؟ بكره

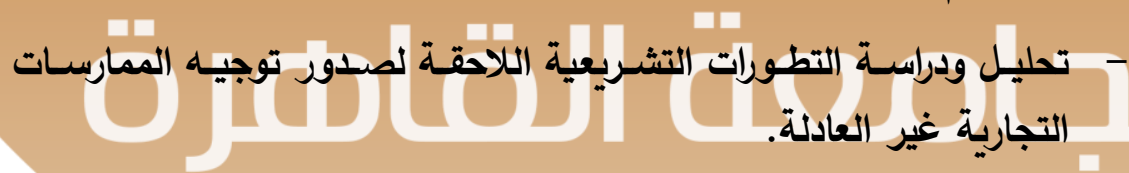
: 1

Duivenvoorde, op. cit., p. 17. 
مجلة القانون والاقتصاد - ملحق خاص بمناسبة مرور مائة وخمسين عام

على إنشاء كلية الحقوق - جامعة القاهرة - العدد (الثانى والتسعون)

3- أهمية الدراسة:

تستمد هذه الدراسـة أهميتها من الدور الذي يلعبه تعزيز حماية المستهلك

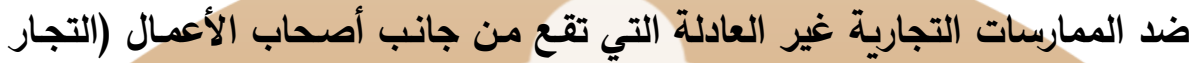

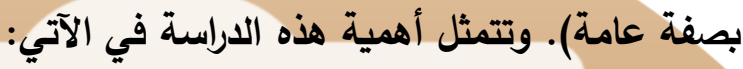

- - محاولــة العـد والقضـاء على الممارسـات التجاريـة غيـر العادلـة؛ لتحقيتق

المصالح الاقتصادية للمستهلكين.

المحافظة على المصالح المشروعة للمنافسين في السوق المعنية.

التعرف على الممارسات التجاربية المضللة.

- - التعرف على الممارسات التجارية العدوانية.

تعزيز مفهوم المستهاك الذي ينبفي أن تتوافر لله الحماية القانونية.

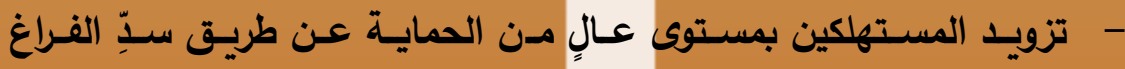

المتواجد في التشريعات المختلفة.

- تزويد مَنْ له شكوى أو مطالبة بأسـانيد وأدلـة قانونية يعتمدون عليها في

هذا الثأن.

- - زيادة الثقة في المعاملات بين الثركات والمستهاكين.

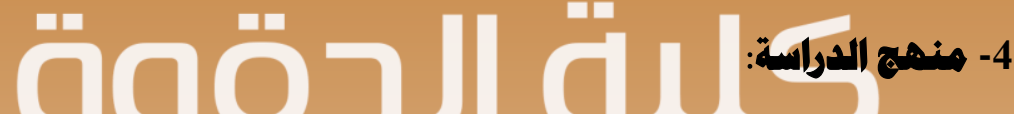

نظرًا لطبيعـة الموضسوع، فقد تمَّ اعتمـاد منـاهج متنوعـة؛ وصـيّة وتحليليّة،

المنهج الوصفي: سوف يُستخدم في بيان الممارسيات التجاريـة غير العادلة

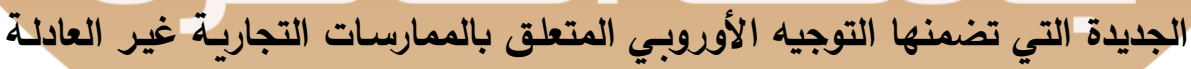

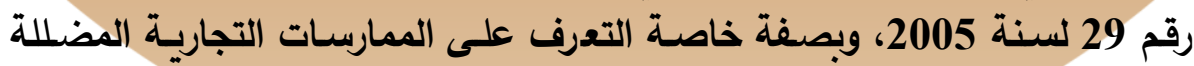
والعدوانية، وتحديد مفهوم المستهلك المستفيد من حظر هذه الممارسات. و ويستخدم

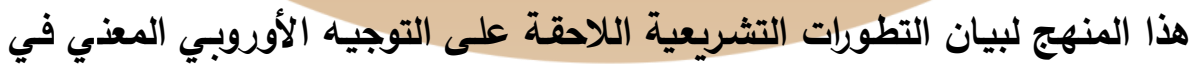
هذا الثأن. 


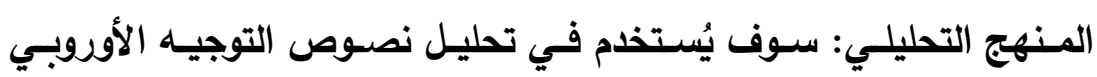

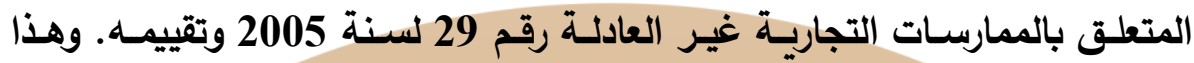

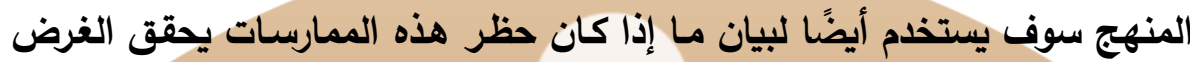

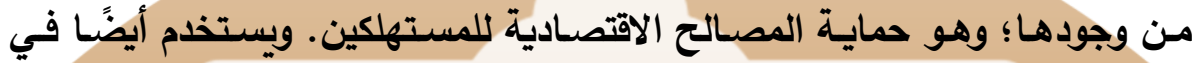
تحليل التطورات التشريعية اللاحقة للتوجيه المعنيّ في هذا الثيأن.

5- تصديد نطاق الدراسة:

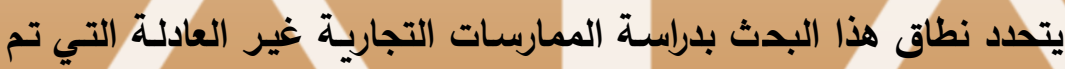

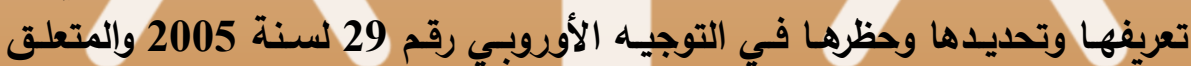
بالممارسات التجارية غير العادئة.

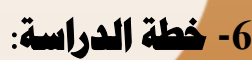

تهتم هذه الدراسة بالممارسات التجارية غير العادلة وفقًا للمتطلبات الجديدة

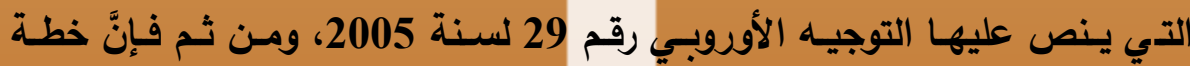

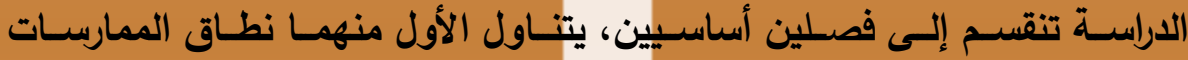

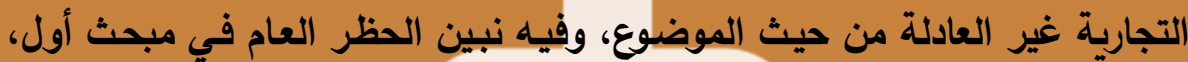

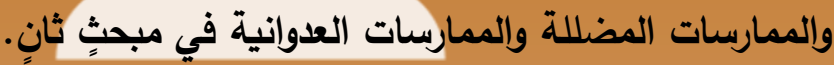

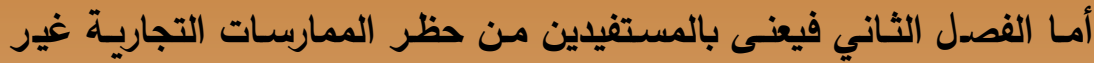

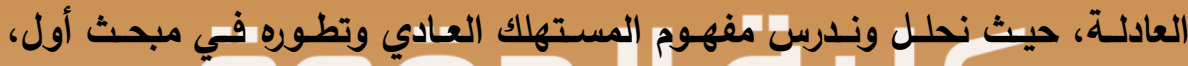

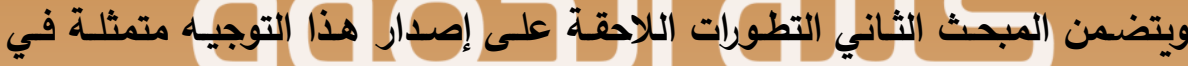

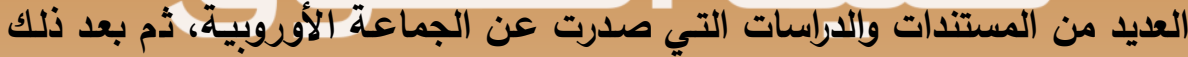

\section{تأتي الخاتمة. (1) وبناءً على ذلك، تكون خطة الدراسة كما يأتي:} مطلب تمهيدي: التعريـف بالتوجيـه الأوروبي رقم 29 لسنة 2005 ونطاق تطبيقه وإنفاذه. الفصل الأول: نطاق الممارسـات التجاريـة غير العادلة من حيث الموضوع،

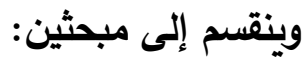


مجلة القانون والاقتصاد - ملحق خاص بمناسبة مرور مائة وخمسين عام

على إنثاء كلية الحقوق - جامعة القاهرة - العدد (الثانى والتسعون)

المبحث الأول: الحظر العام للممارسات غير العادلة.

المبحث الثاني: الممارسات المضللة والممارسات العدوانية.

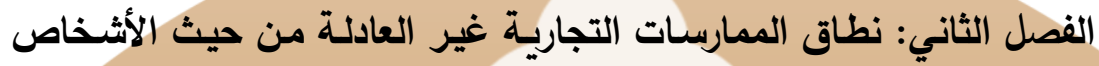
والتطورات الأوروبية الحديثة المتعلقة بحظر هذه الممارسات، وينقسم إلى مبحثين: المبـث الأول: المسـفيدون مـن حظـر الممارسـات غيـر العادلـة (مفهـوم

\section{المستهلك (لعادي).}

المبحث الثاني: التطورات الحديثة.

الخاتمة.

\section{كلية الحقوق}

حامعة القالقارة 


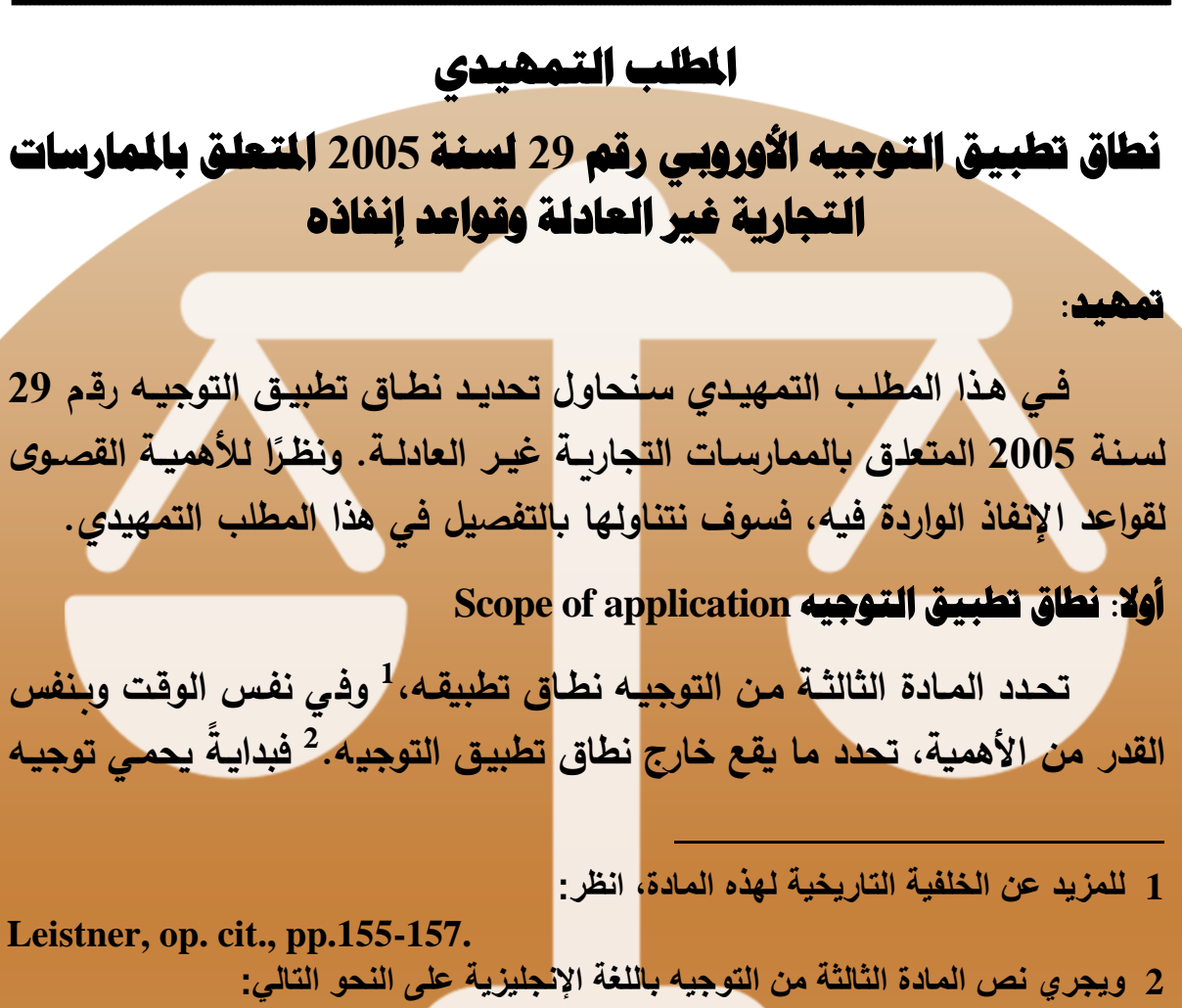

"1. This Directive shall apply to unfair business-to-consumer commercial practices, as laid down in Article 5, before, during and after a commercial transaction in relation to a product.

2. This Directive is without prejudice to contract law and, in particular, to the rules on the validity, formation or effect of a contract.

3. This Directive is without prejudice to Community or national rules relating to the health and safety aspects of products.

4. In the case of conflict between the provisions of this Directive and other Community rules regulating specific aspects of unfair commercial practices, the latter shall prevail and apply to those specific aspects.

5. For a period of six years from 12 June 2007, Member States shall be able to continue to apply national provisions within the field approximated by this Directive which are more restrictive or prescriptive than this Directive and which implement directives containing minimum harmonisation clauses. These measures 
مجلة القانون والاقتصاد - ملحق خاص بمناسبة مرور مائة وخمسين عام

على إنثاء كلية الحقوق - جامعة القاهرة - العدد (الثانى والتسعون)

الممارسات التجارية غير العادلة المصالح الاقتصادية للمستهلكين الذين يكون في

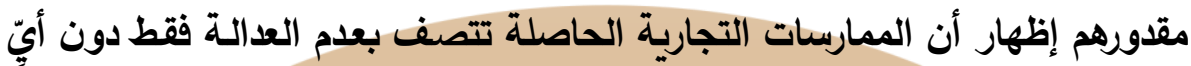

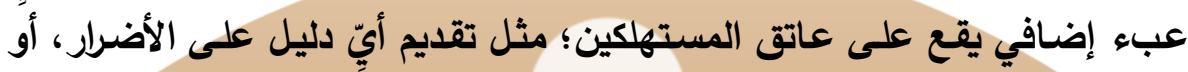

الإهمال أو سوء النية من جانب التاجر. 1

must be essential to ensure that consumers are adequately protected against unfair commercial practices and must be proportionate to the attainment of this objective. The review referred to in Article 18 may, if considered appropriate, include a proposal to prolong this derogation for a further limited period.

6. Member States shall notify the Commission without delay of any national provisions applied on the basis of paragraph 5 .

7. This Directive is without prejudice to the rules determining the jurisdiction of the courts.

8. This Directive is without prejudice to any conditions of establishment or of authorisation regimes, or to the deontological codes of conduct or other specific rules governing regulated professions in order to uphold high standards of integrity on the part of the professional, which Member States may, in conformity with Community law, impose on professionals.

9. In relation to 'financial services', as defined in Directive 2002/65/EC, and immovable property, Member States may impose requirements which are more restrictive or prescriptive than this Directive in the field which it approximates.

10. This Directive shall not apply to the application of the laws, regulations and administrative provisions of Member States relating to the certification and indication of the standard of fineness of articles of precious metal."

1 انظر الفقرة الثانية من المـادة الحاديـة عشرة. ويجري نصـها باللغـة الإنجليزيـة على النـو

" 2 . Under the legal provisions referred to in paragraph 1, Member States shall confer upon the courts or administrative authorities powers enabling them, in cases where they deem such measures to be necessary taking into account all the interests involved and in particular the public interest: 


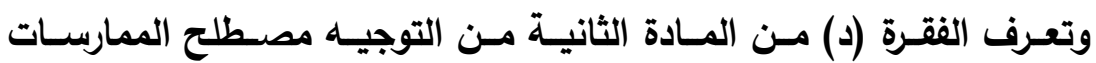

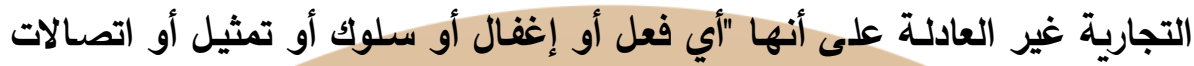

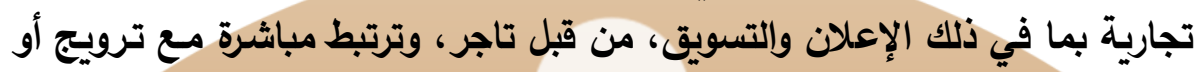

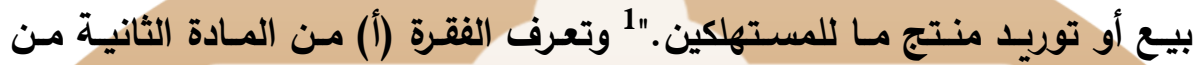

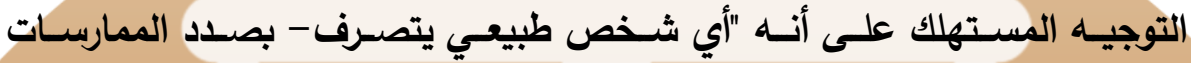

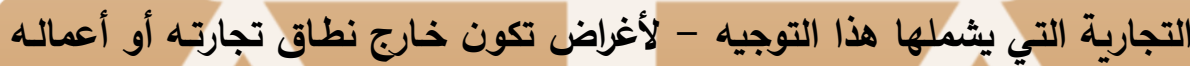

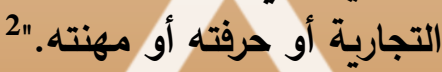

وقد اقتصر التعربف على الثخص الطبيعي، ولا يمتد مفهوم المستهلك -

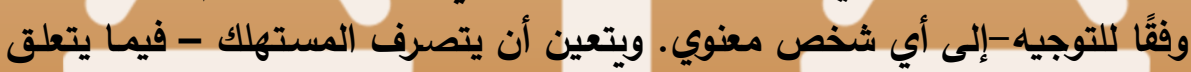

(a) to order the cessation of, or to institute appropriate legal proceedings for an order for the cessation of, unfair commercial practices; or

(b) if the unfair commercial practice has not yet been carried out but is imminent, to order the prohibition of the practice, or to institute appropriate legal proceedings for an order for the prohibition of the practice,

even without proof of actual loss or damage or of intention or negligence on the part of the trader."

Cristina Poncibo and Rossella Incardona, 'The Unfair Commercial Practices Directive: A Faltering First Step' (2005) 1(2) London Law Review, pp. 317-337, at 319.

$$
1 \text { ويجري نص هذه الفقرة باللغة الإنجليزية على النحو التالي: }
$$

"'business-to-consumer commercial practices" (hereinafter also referred to as commercial practices) means any act, omission, course of conduct or representation, commercial communication including advertising and marketing, by a trader, directly connected with the promotion, sale or supply of a product to consumers."

$$
2 \text { ويجري نصها باللغة الإنجليزية على النحو التالي: }
$$

“'consumer' means any natural person who, in commercial practices covered by this Directive, is acting for purposes which are outside his trade, business, craft or profession." 
مجلة القانون والاقتصاد - ملحق خاص بمناسبة مرور مائة وخمسين عام

على إنشاء كلية الحقوق - جامعة القاهرة - العدد (الثانى والتسعون)

بالممارسـات التجاربـة غير العادلـة التـي يثـلها التوجيه- لأغراض لا تكون لها

صلة بنطاق تجارته أو أعماله التجارية أو حرفته أو مهنته. 1

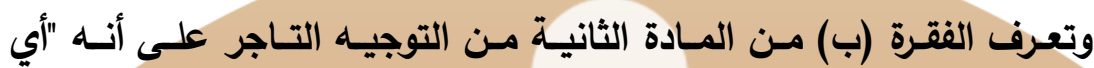

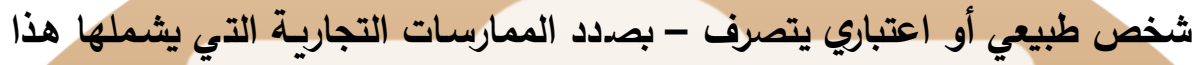

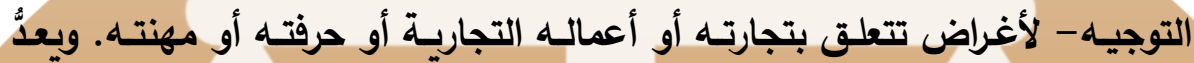

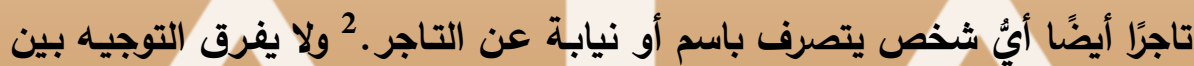

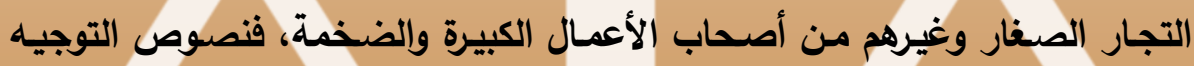

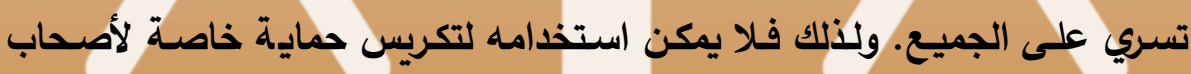

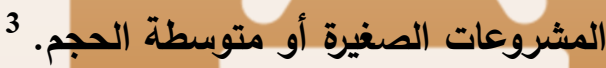

وتطبق نصـوص توجيـه الممارسـات التجاربـة غير العادلـة على الممارسـات

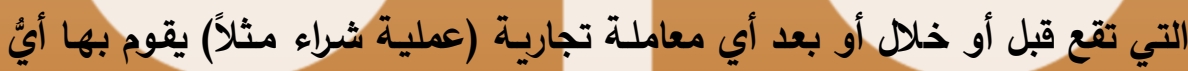

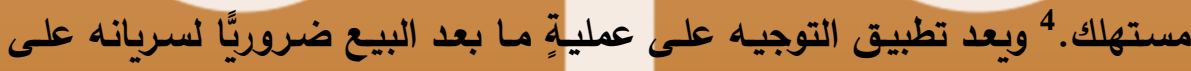

: 1

Reilly, op. cit., p. 113; and Keirsbilck, op. cit., p. 228.

2 ويجري نصها باللغة الإنجليزية على النحو التالي:

"'trader' means any natural or legal person who, in commercial practices covered by this Directive, is acting for purposes relating to his trade, business, craft or profession and anyone acting in the name of or on behalf of a trader."

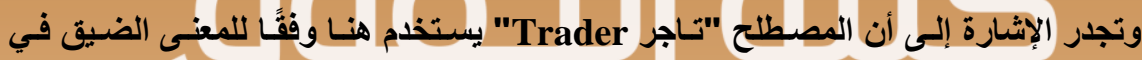

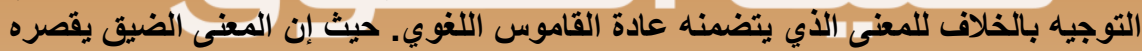

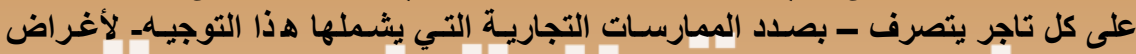
تتعلق بتجارته أو أعماله التجارية أو حرفته أو مهنته.

H.W. Micklitz, 'Unfair Commercial Practices and Misleading Advertising' in Hans-W. Micklitz, Norbert Reich and Peter Rott, Understanding EU Consumer Law (Oxford: Intersentia, 2009), p. 74. 4 انظر الفقرة الأولى من المادة الثالثة التي يجري نصها باللغة الإنجليزية على النحو التالي:

"1. This Directive shall apply to unfair business-to-consumer commercial practices, as laid down in Article 5, before, during and after a commercial transaction in relation to a product." 
الحالات التي يكون فيها لدى المستهلك علاقة مستمرة مـع التاجر، كما هو الحال

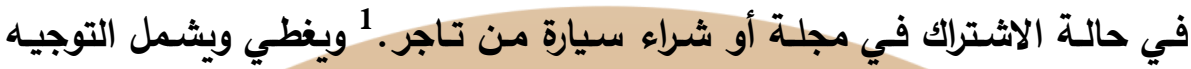
جوانب العلاقة التي لا يحكمها العقد الأساسي.

وفى حالة عدم الالتزام بالوعود التي قطعت للمستهلكين في مرحلة مـا قبل

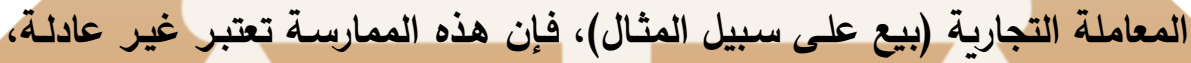

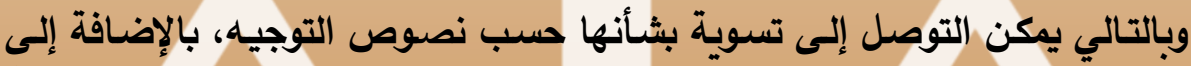
أيّ تعويضـات تعاقديـة أخرى متاحـة للمستهلك.

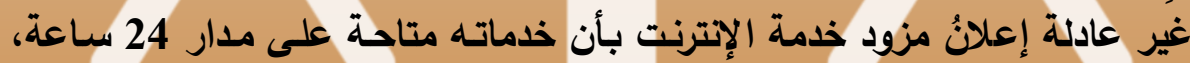

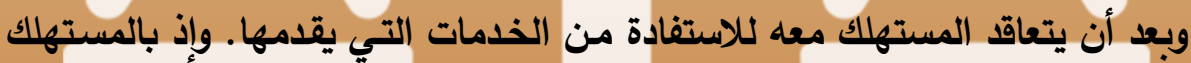

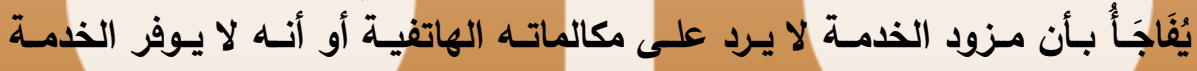

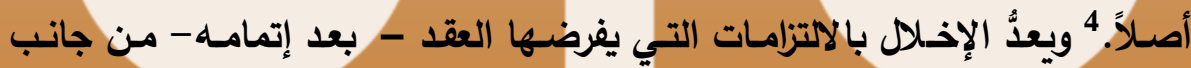

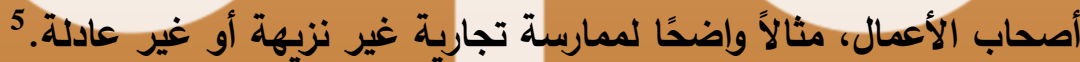
وكما سبق أن ذكرنا يحمي التوجيه المصالح الاقتصادية للمستهلكين. وبناءً

Abbamonte, op. cit., p. 699.

Nathan Reilly, op. cit., p. 116; and B. B. Duivenvoorde, The Consumer Benchmarks in the Unfair Commercial Practices Directive (Switzerland, Springer International Publishing, 2015) p. 14.

2 انظر الفقرة الثالثة عشرة من ديباجة التوجيه، ويجري نص هذه الفقرة باللتفة الإنجليزية على الفى

" ... In order to support consumer confidence the general prohibition should apply equally to unfair commercial practices which occur outside any contractual relationship between a trader and a consumer or following the conclusion of a contract and during its execution...."

Abbamonte, op. cit., p. 699. 
مجلة القانون والاقتصاد - ملحق خاص بمناسبة مرور مائة وخمسين عام

على إنثاء كلية الحقوق - جامعة القاهرة - العدد (الثانى والتسعون)

على ذلك فإنـه ينسـق ويقرب بين الجوانب الاقتصـادية للمعاملات التي تـم بين

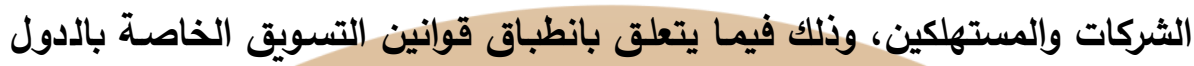
الأعضاء في الآِّحاد الأوروبي. 1

وتعتبر القضايا المتعلقة بالطعم وآداب السلوك taste and decency من

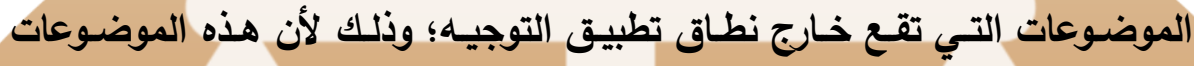

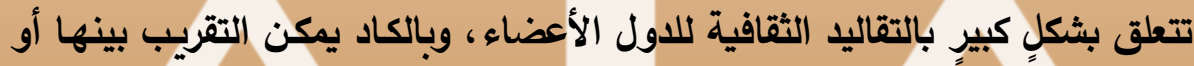

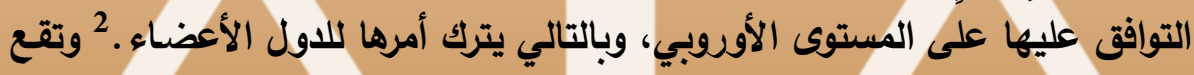

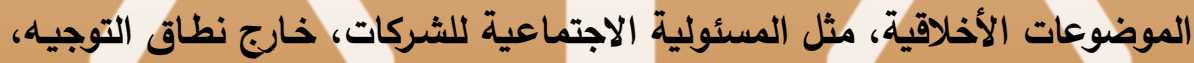

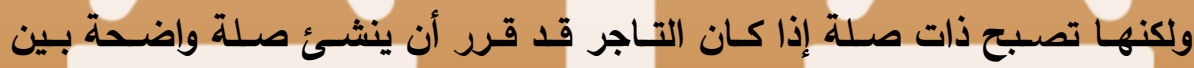

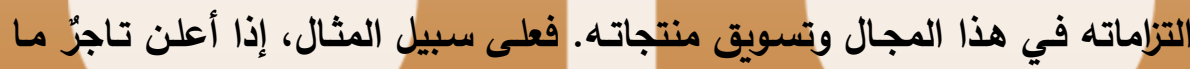

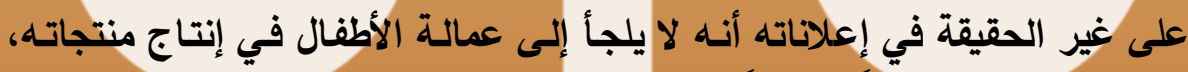

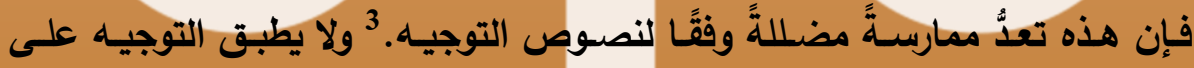

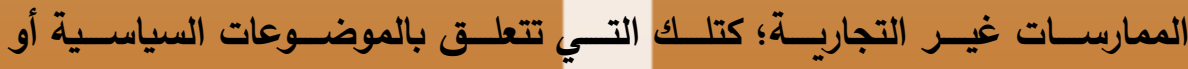

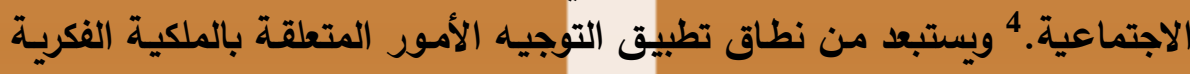
والممتلكات غير المنقولة. 5 وتعـدُّ جوانـب السـلامة في المنتجـات والخـدمات والمتعلقـة بصــة وأمــان

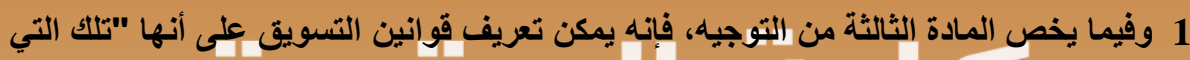

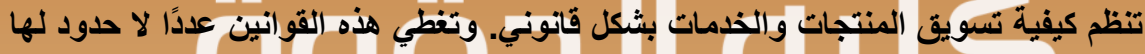

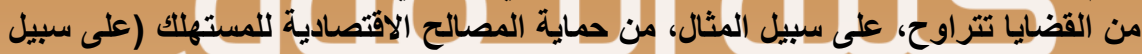

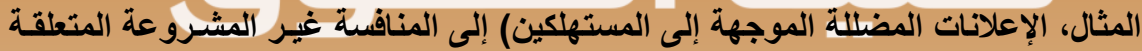

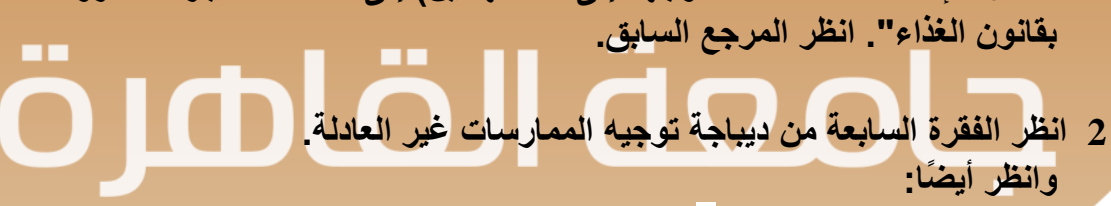

Abbamonte, op. cit., p. 699 ; and Duivenvoorde, op. cit., p. 15. : 3

Abbamonte, op. cit., p. 699. 4

Duivenvoorde, op. cit., p.14. 
المستهلك خـارج نطاق التوجيه،، 1 ولكنها تصبح ذات صلـة عند تقديم المعلومـات ذات الصلة إلى المستهلك بطريقة غير نزيهة أو عادلة بموجب نصوص التوسيه التوجيه.

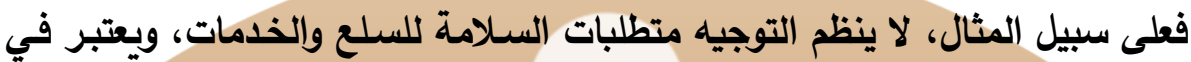

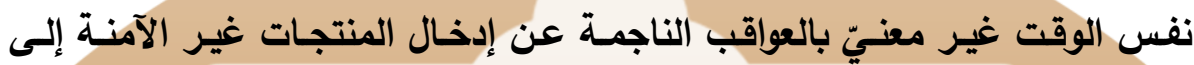

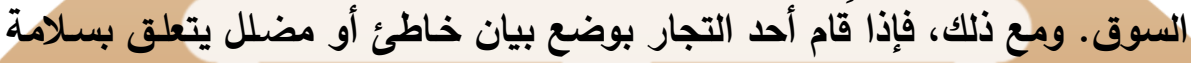

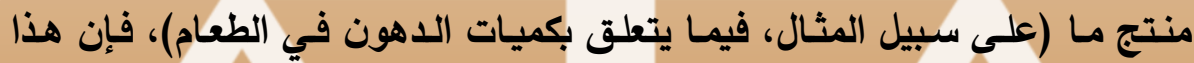

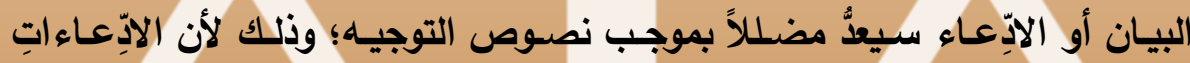

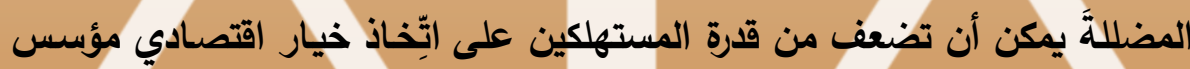
على علم تام، وبالتالي قان يضرٌ بمصالحه الاقتصادية. 2

ولا يتعامل التوجيه مع قانون العقود، وليس لله أي تأثير على شروط تثكيل

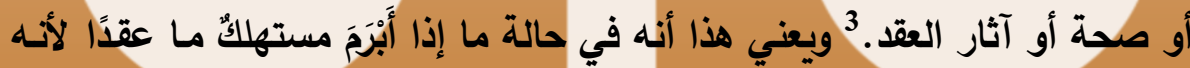

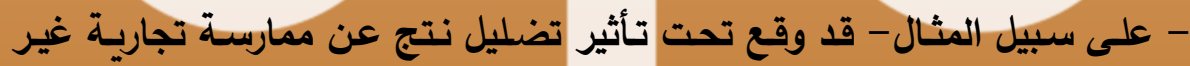

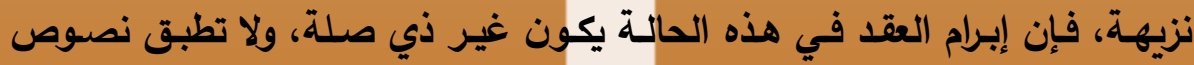

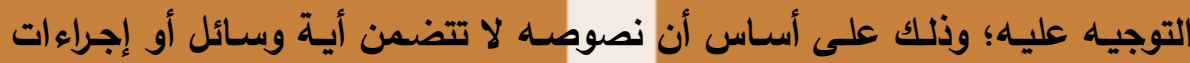

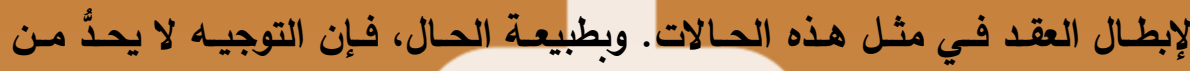

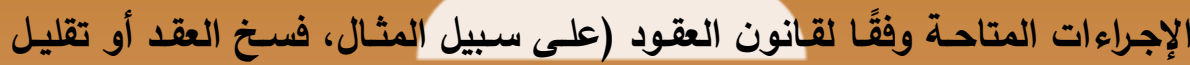
مناسب للسعر) المتاحة للمستهلك الذي أبرم عقدًا تعت تأثير التضليل. 1 انظر الفقرة الثالثة من المادة الثالثة من التوجيه. ويجري نصها باللغة الإنجليزية على النحو "3. This Directive is without prejudice to Community or national rules relating to the health and safety aspects of products."

Abbamonte, op. cit., pp. 699-700.

3 انظر الفقرة الثانية من المادة الثالثة من التوجيه. ويجري نص هذه الفقرة باللفـة الإنجليزيـة

$$
\text { على النحو التالي: }
$$

"2. This Directive is without prejudice to contract law and, in particular, to the rules on the validity, formation or effect of a contract."

Abbamonte, op. cit., p. 700. 
مجلة القانون والاقتصاد - ملحق خاص بمناسبة مرور مائة وخمسين عام

على إنثاء كلية الحقوق - جامعة القاهرة - العدد (الثانى والتسعون)

الحالة، فإن المستهلك له أن يقيم دعوى أمام المحكمة المدنية، وبمـا أن إبرام العقد فئدا

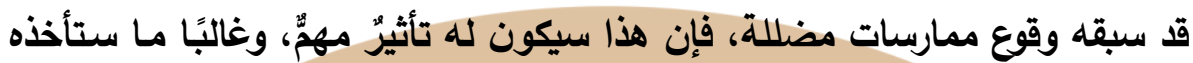

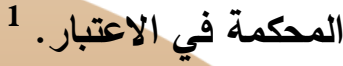
ولمــاكـان الهـدف المباشــر للتوجيـهـ هـو حمايــة المصـالح الاقتصــادية

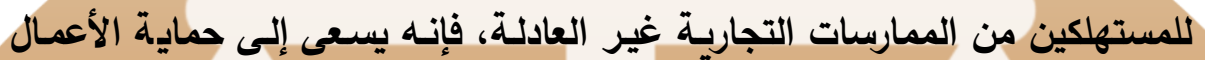

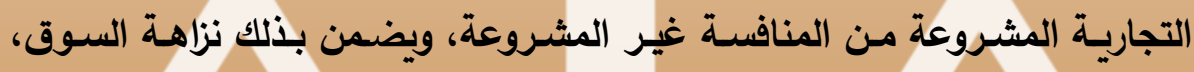

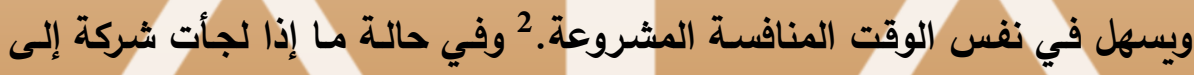

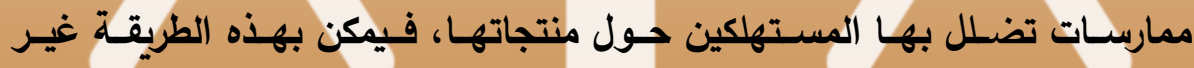

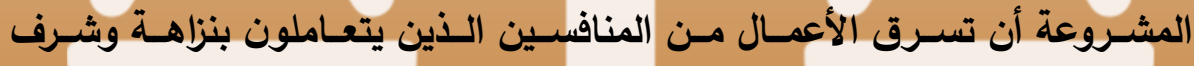

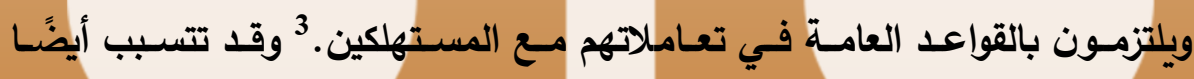

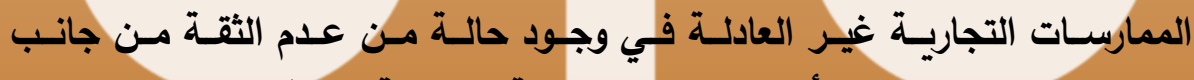

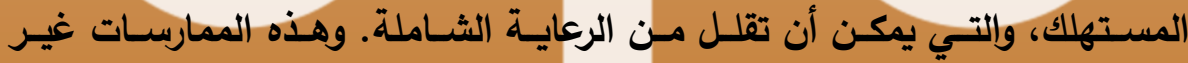

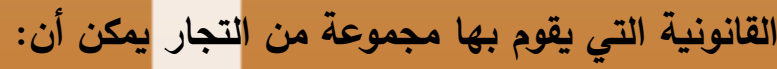

"تؤدي بالمستهاكين إلى الثك في نزاهة هذه الصناعة بأكملها أو لعدم توافر

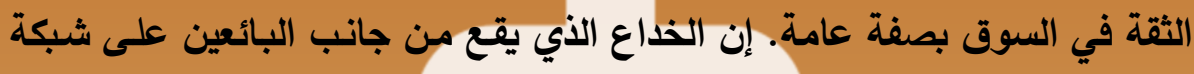

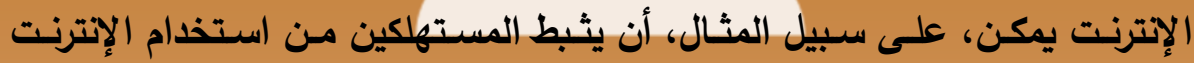

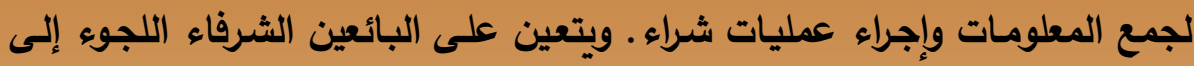

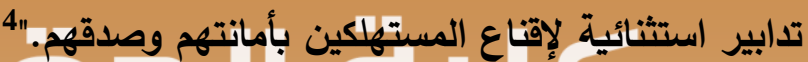
وعلى عكس ما كان يجري به العمل في ظل توجيه سابق متعلق بالإعلاذات

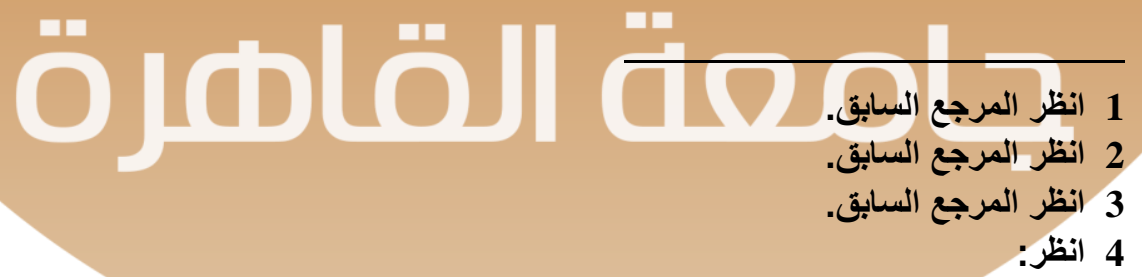

Timothy J. Muris, The Interface of Competition and Consumer Protection 5 (Prepared Remarks at the Fordham Corporate Law Institute's 29th Annual Conference on International Antitrust Law and Policy, New York City, Oct. 31, 2002). 
المضللة وإلمقارنة، ${ }^{1}{ }^{1}$

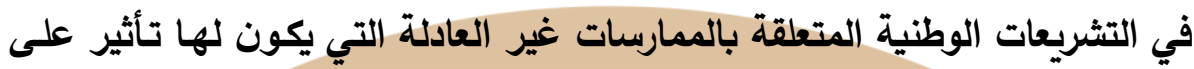

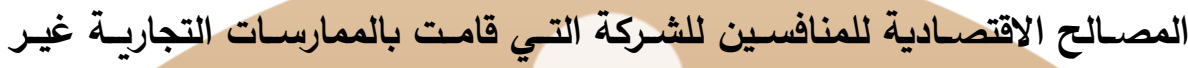

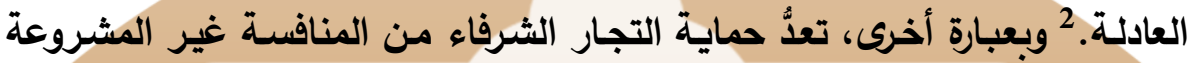

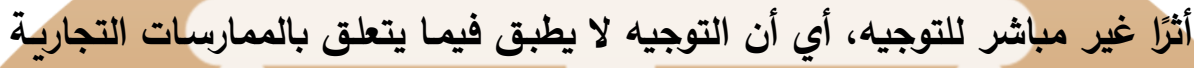

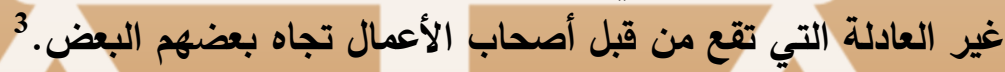
وقد سبق أن ذكرنـا أن الشرط الـلازم والمسبق لتطبيق التوجيه هو حصول

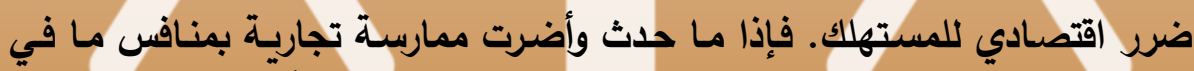

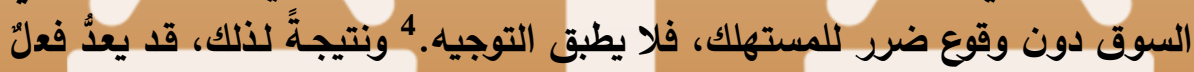

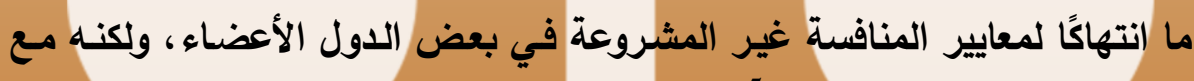

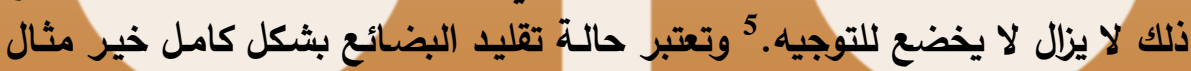

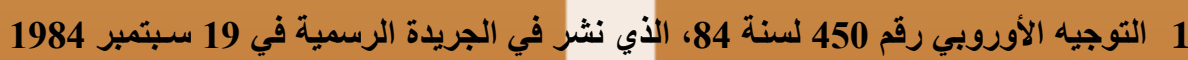

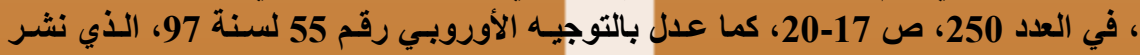

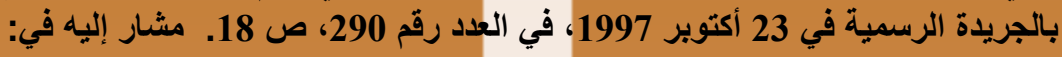

Poncibo and Incardona, op. cit., p. 319.

2

"It neither covers nor affects the national laws on unfair commercial practices which harm only competitors' economic interests or which relate to a transaction between traders...."

Poncibo and Incardona, op. cit., p. 319.

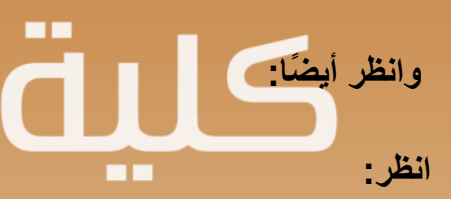

Thomas Wilhelmsson, op. cit., p. 475; and H.W. Micklitz, 'Unfair Commercial Practices and Misleading Advertising' in Hans-W. Micklitz, Norbert Reich and Peter Rott, Understanding EU Consumer Law (Oxford: Intersentia, 2009), p. 73.

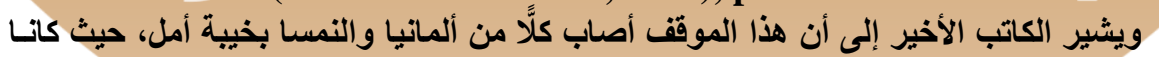

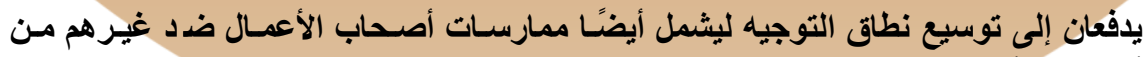

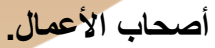
4

Abbamonte, op. cit., p. 700. : 5 
مجلة القانون والاقتصاد - ملحق خاص بمناسبة مرور مائة وخمسين عام

على إنشاء كلية الحقوق - جامعة القاهرة - العدد (الثانى والتسعون)

على هذا. 1 ويعدُّ هذا الفعل من الأفعال المحظورة في بعض الدول، على أسـاس أنه

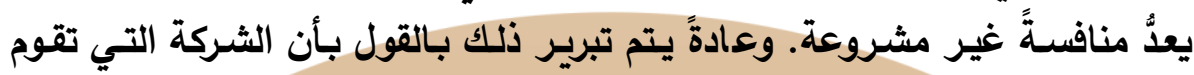

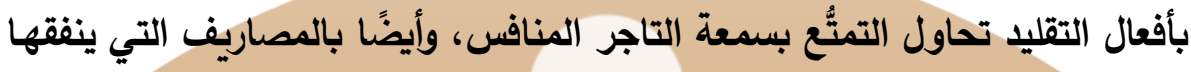

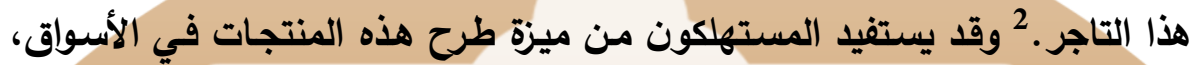

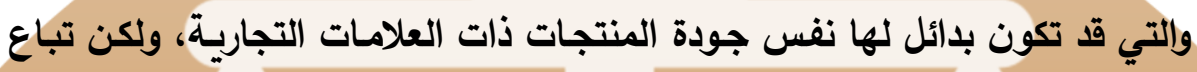

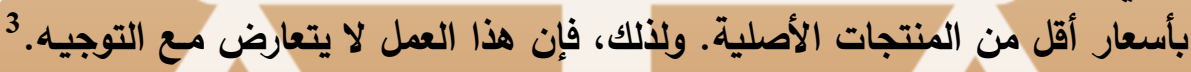

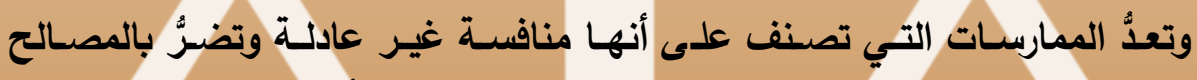

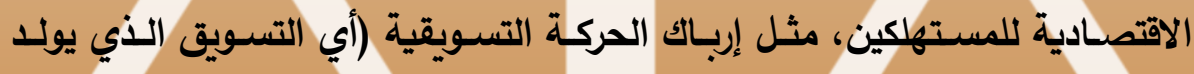

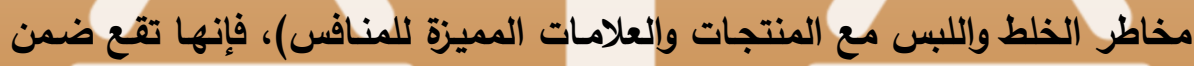

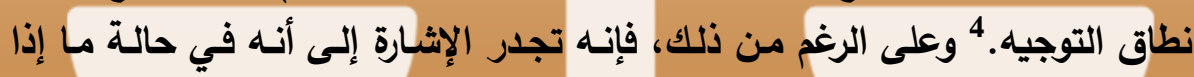

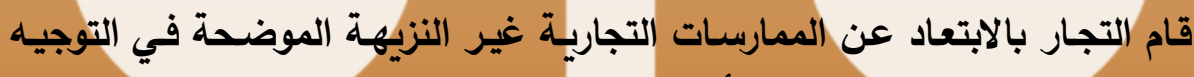

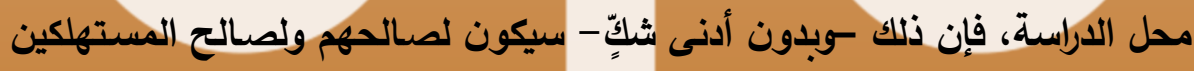
أيضًا، ومن ثم ستتمثل النتيجة الدتمية في رقابة فانة أكثر فعالية على الثي التطبيق الفعال

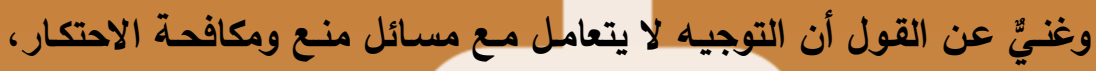

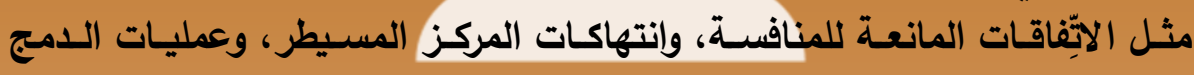

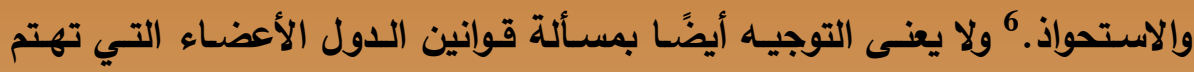

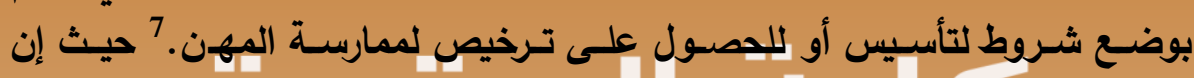

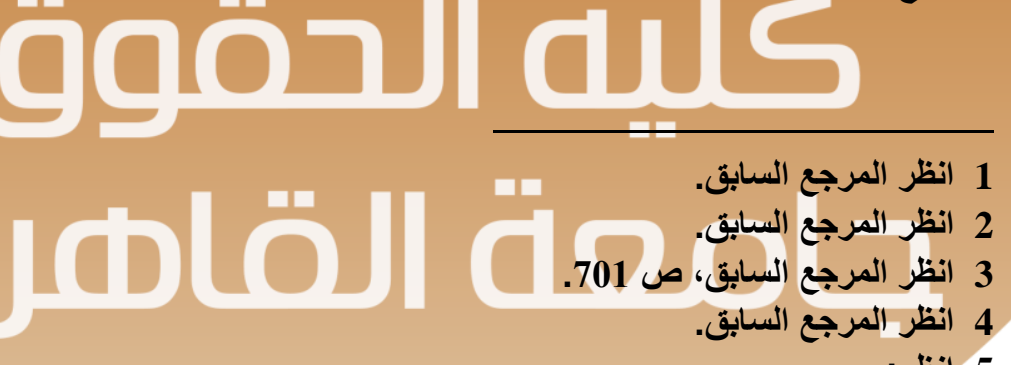

: 5

Poncibo and Incardona, op. cit., p. 319.

Abbamonte, op. cit., p. 701.

(نظر:

7 انظر الفقرة الثامنة مـن المـادة الثالثة التـي يجري نصـها ـ باللغـة الإنجليزيـة ـ على النحو 
التوجيه لا يؤثر على مدونات قواعد السلوك ولا القواعد الأخرى التي تحكم المهن التي يجوز للدول الأعضاء أن تفرضها على على المهنيين.

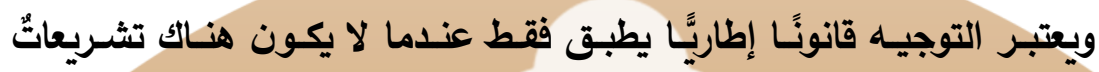

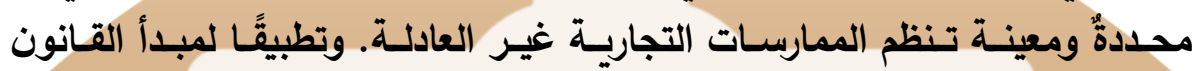

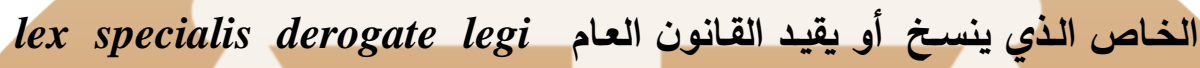
generali principle

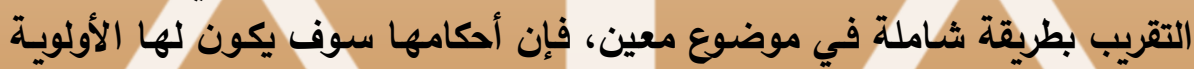

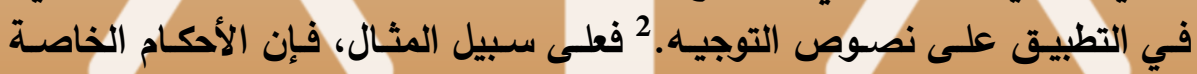

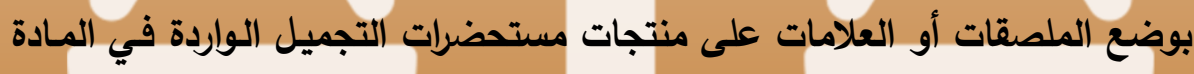

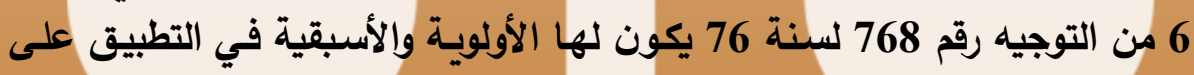

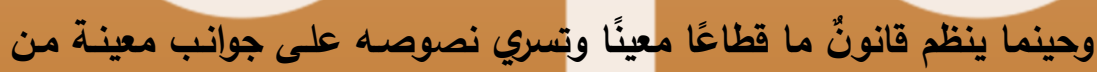

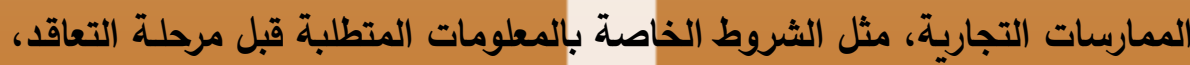

“ 8. This Directive is without prejudice to any conditions of establishment or of authorisation regimes, or to the deontological codes of conduct or other specific rules governing regulated professions in order to uphold high standards of integrity on the part of the professional, which Member States may, in conformity with Community law, impose on professionals."

Abbamonte, op. cit., p. 701.

2 انظر الفقرة الرابعة من المـادة الثالثة التي يجري نصـها ـ باللغـة الإنجليزيـة ـــلـى النـو التالي:

"4. In the case of conflict between the provisions of this Directive and other Community rules regulating specific aspects of unfair commercial practices, the latter shall prevail and apply to those specific aspects."

Abbamonte, op. cit., p. 701. 
مجلة القانون والاقتصاد - ملحق خاص بمناسبة مرور مائة وخمسين عام

على إنثاء كلية الحقوق - جامعة القاهرة - العدد (الثانى والتسعون)

فـإن التوجيـه يكـون قـابلاً للتطبيـق على العناصـر الأخـرى. ${ }^{1}$ ومثال آخـر، يسـري

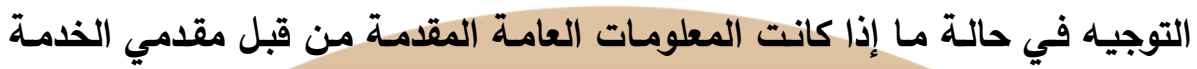

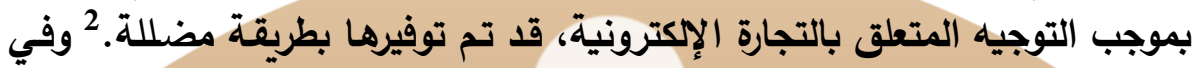

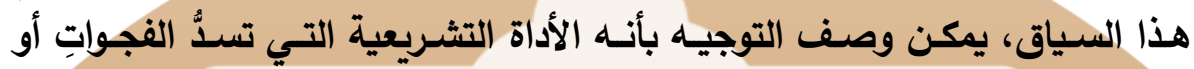

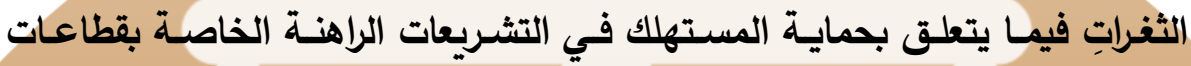

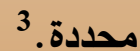

Enforcement Rules ثانيا: القواعد المتماقة بإنفاذ التوفيه

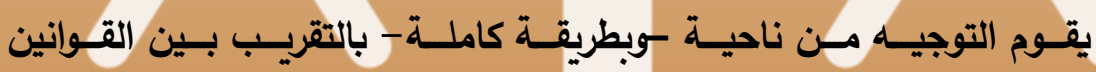

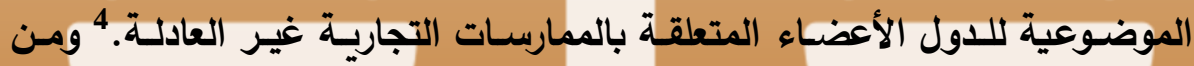

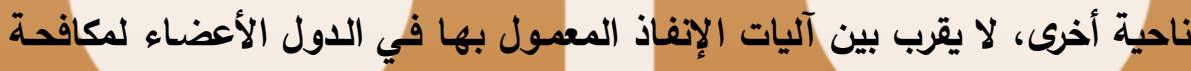

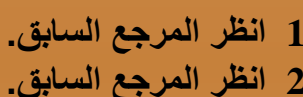

3 بالممارسات التجارية غير النزيهة. ويجري نصها باللغة الإنجليزية على النحو التالي:

"Member States shall neither restrict the freedom to provide services nor restrict the free movement of goods for reasons falling within the field approximated by this Directive."

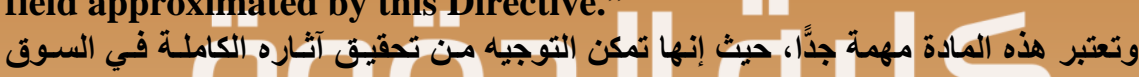

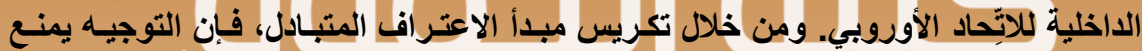

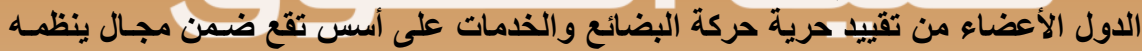

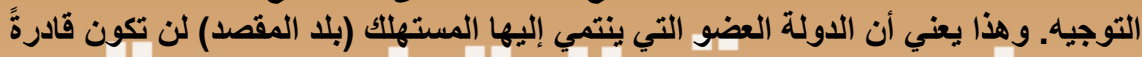

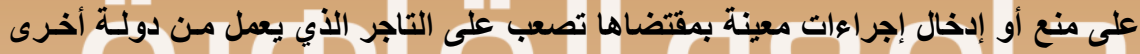

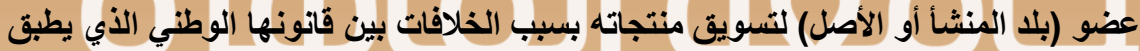

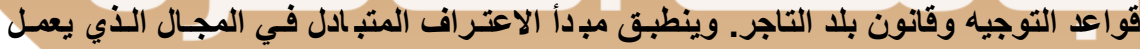

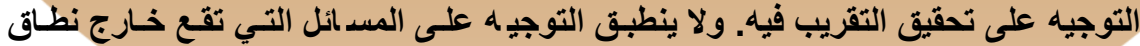

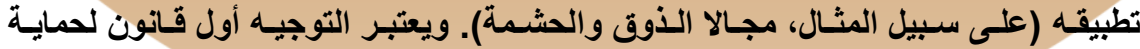
المستهلك الأوروبي يتضمن مبذأ الاعتر افت المتبادل.

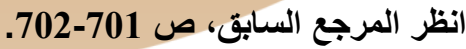

4 للمزيد عن إنفاذ توجيه الممارسات التجارية غير العادلة في إيرلندا والمملكة المتحدة انظر: Reilly, op. cit., p. 119 et seq. 
هذه الممارسـات غير العادلـة. ${ }^{1}$ فوفقًا للفقرة الأولى من المـادة الحاديـة عثرة من

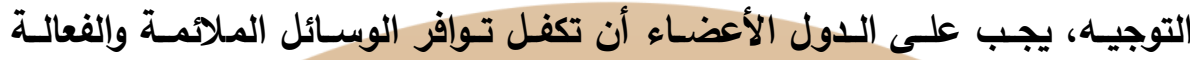

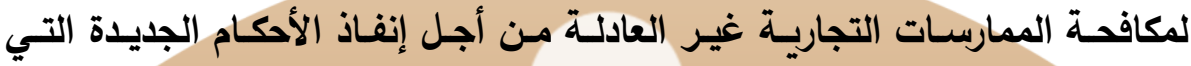

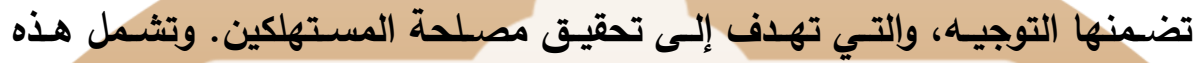
الوسائل النصوص القانونية التي تمنح بموجبها الأثخاص أو المنظمـات ممن لهم الهم

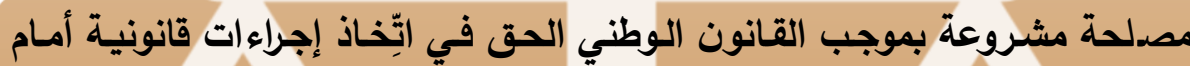

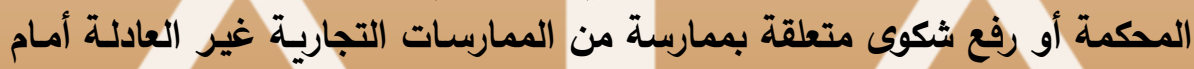

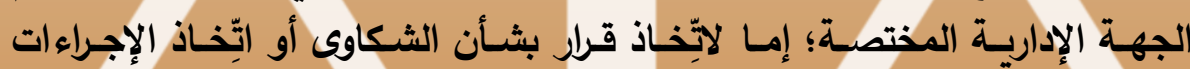

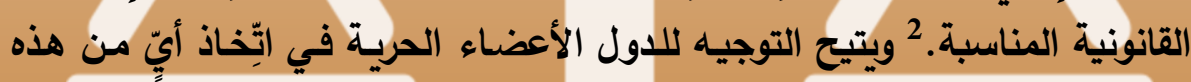

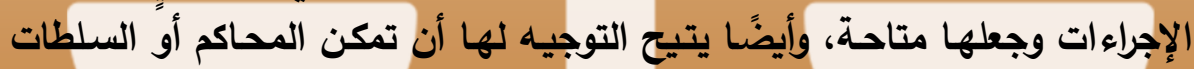
الإداريـة أن تتطلب أيَّ إجراء سـابق للتعامـل مـع الثكاوى.

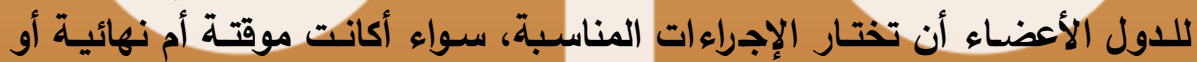

Duivenvoorde, op. cit., p. 15 and Abbamonte, op. cit., p. 711.

$$
\text { : } 1
$$

2 ويجري نص هذه الفقرة باللغة الإنجليزية على النحو التالي:

"Member States shall ensure that adequate and effective means exist to combat unfair commercial practices in order to enforce compliance with the provisions of this Directive in the interest of consumers. Such means shall include legal provisions under which persons or organisations regarded under national law as having a legitimate interest in combating unfair commercial practices, including competitors, may:

(a) take legal action against such unfair commercial practices; and/or (b) bring such unfair commercial practices before an administrative authority competent either to decide on complaints or to initiate appropriate legal proceedings."

3 ويجري نص هذه الفقرة (الأولى من المادة الحادية عشرة) باللغة الإنجليزية على النحو التالي:

"It shall be for each Member State to decide which of these facilities shall be available and whether to enable the courts or administrative authorities to require prior recourse to other established means of dealing with complaints...." 
مجلة القانون والاقتصاد - ملحق خاص بمناسبة مرور مائة وخمسين عام

على إنشاء كلية الحقوق - جامعة القاهرة - العدد (الثانى والتسعون)

حظر هذه الممارسة ونثر القرار أو البيان التصحيحي.

والخلاصة أن التوجيه - في مادتـه الحادية عشرة - لا يفرض التزامًا محددًا

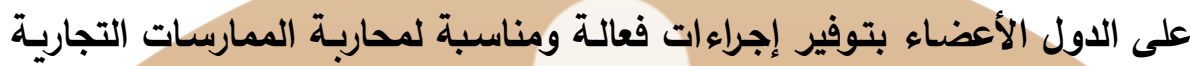

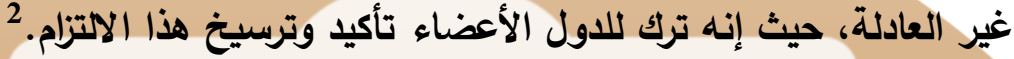

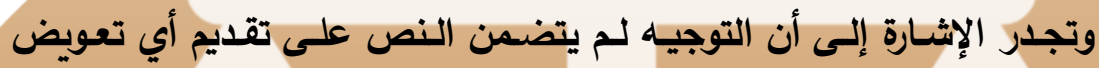

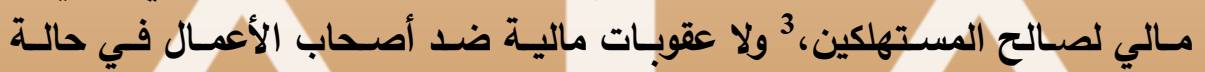

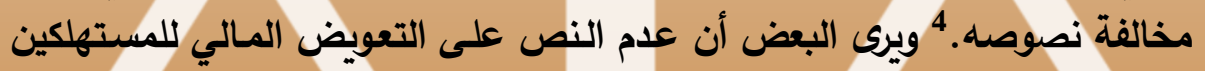

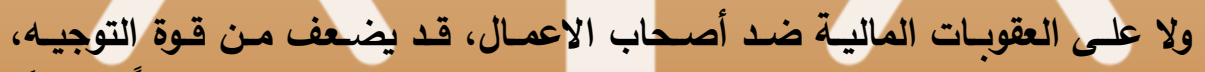

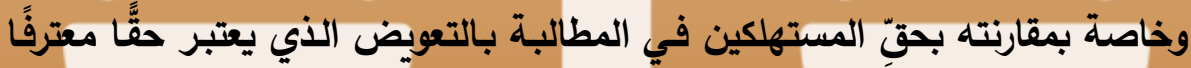

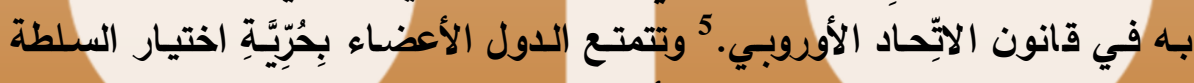

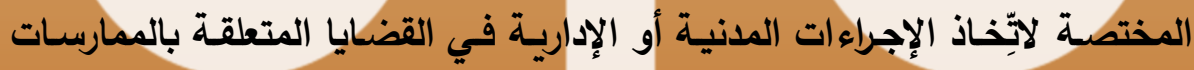

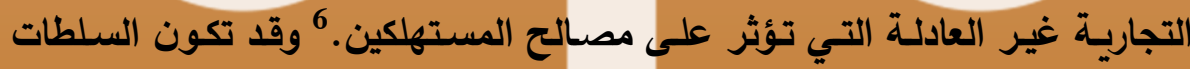

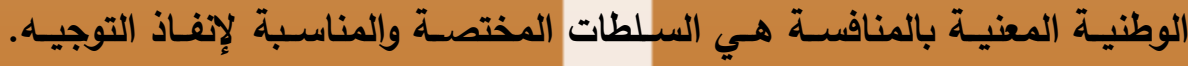

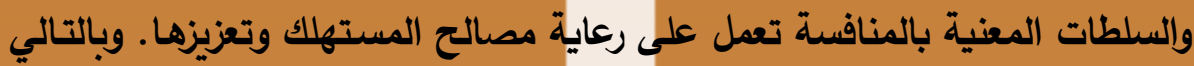

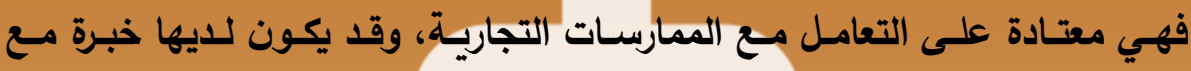

الإعلانات المقارنة والمضلادة علية التعامل 7

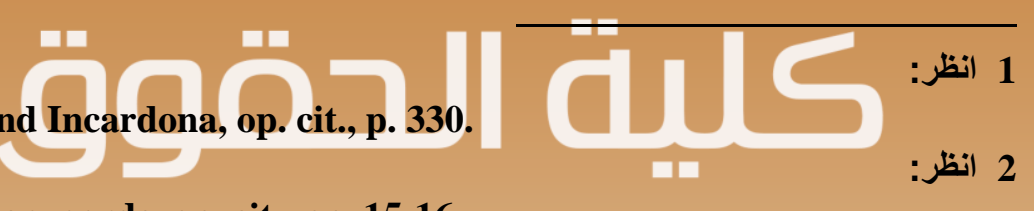

B. B. Duivenvoorde, op. cit., pp. 15-16.

Hugh Collins, op. cit., p. 91.

Duivenvoorde, op. cit., p.16.

Poncibo and Incardona, op. cit., p. 330.

5 5

6 انظر المادة 11 من التوجيه المتعلقة بالإنفاذ.

Poncibo and Incardona, op. cit., p. 330.

7 
ويعدُّ الإنفـاذ الفعـال أمـرًا بـالغ الأهميـة لتحقيق الإمكانـات الكاملـة للتوجيـه،

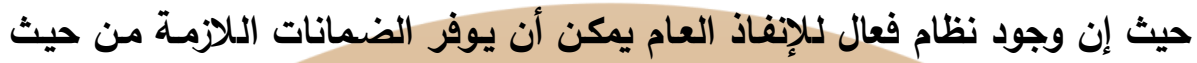

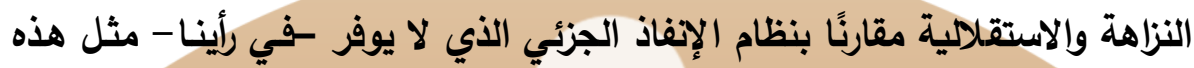

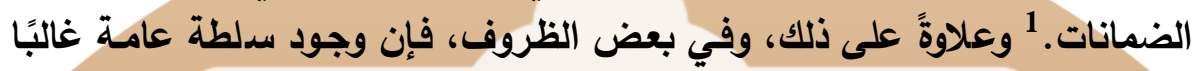

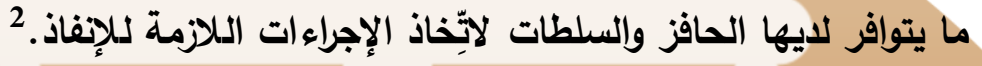

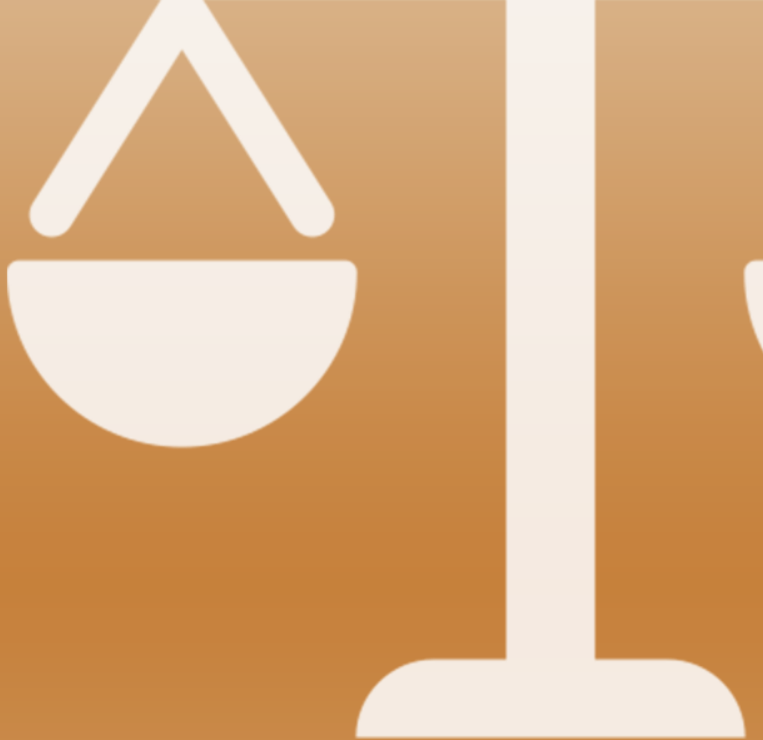

\section{كلية الحقوق}

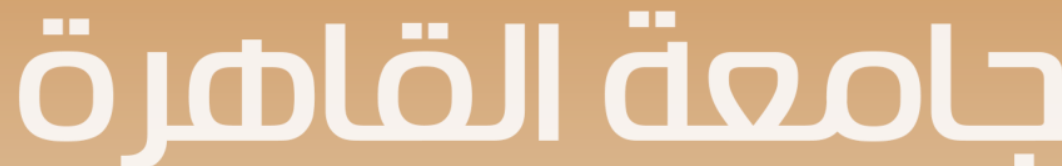

Abbamonte, op. cit., p. 711.

1 
مجلة القانون والاقتصاد - ملحق خاص بمناسبة مرور مائة وخمسين عام

على إنثاء كلية الحقوق - جامعة القاهرة - العدد (الثانى والتسعون)

\section{الفصل الأول \\ نطاق المطارسات التجارية غير العادالة هن هيث الموضمع}

تمهميد وتقشسيم:

يتضمن توجيه الممارسـات التجاربـة غير العادلة رقم 29 لسنة 2005 حظرًا

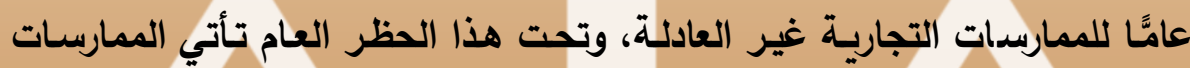

المضللة التي قد تكون عن طريق أفعال أو عن طريق الامتناع عن القيام بعملٍ مـا.

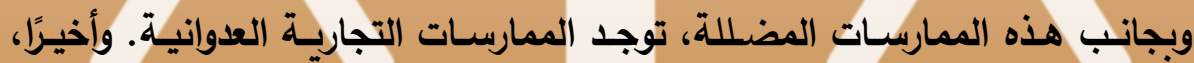

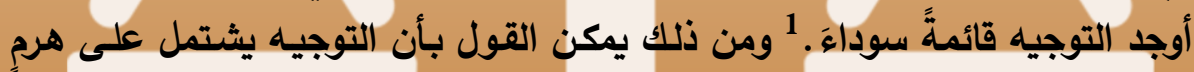

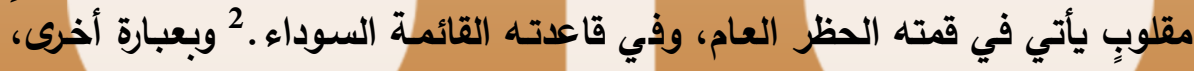

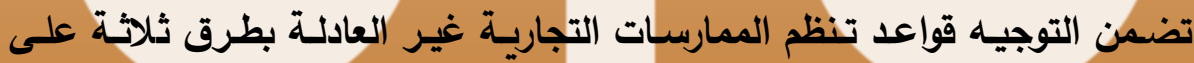

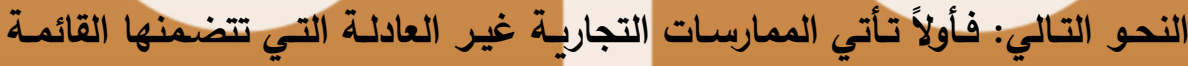

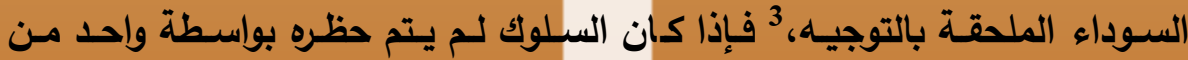

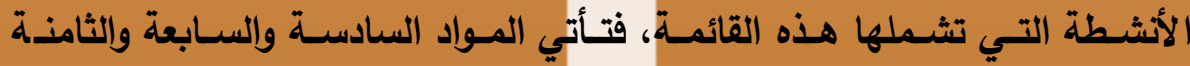

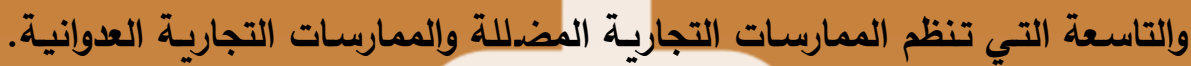

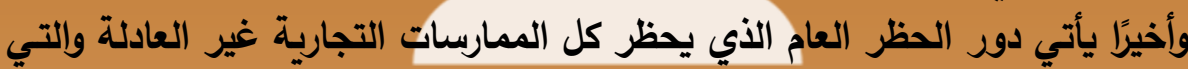
لم تقع تحت طائلة المواد السابق ذئ ذكرها.

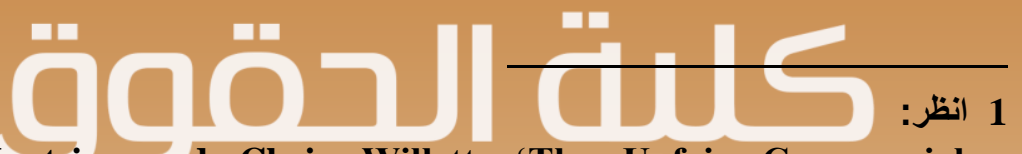

Marios Koutsias and Chris Willett, 'The Unfair Commercial Practices Directive in the UK' (2012) 5 (4) Erasmus Law Review, pp.237-251, at 238.

ويتناول الكاتبان كيفية تطبيق توجيه الممارسات التجاريـة غير العادلـة في المملكة المتحدة

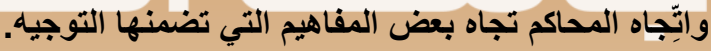

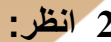

Abbamonte, op. cit., p. 704.

3 تتضمن هذه القائمة عدد 31 ممارسة تعتبر في جميع الأحوال غير عادلة. انظر:

Koutsias and Willett, op. cit., 238.

Reilly, op. cit., p. 114. 

التجارية غير العادلة رقم 29 لسنة 2005 والتطورات التشريعية اللاحقة

ويوضـــح الرســـم التـالي هيكـل الممارســات المحظــورة وفقَّــا للتوجيــه.

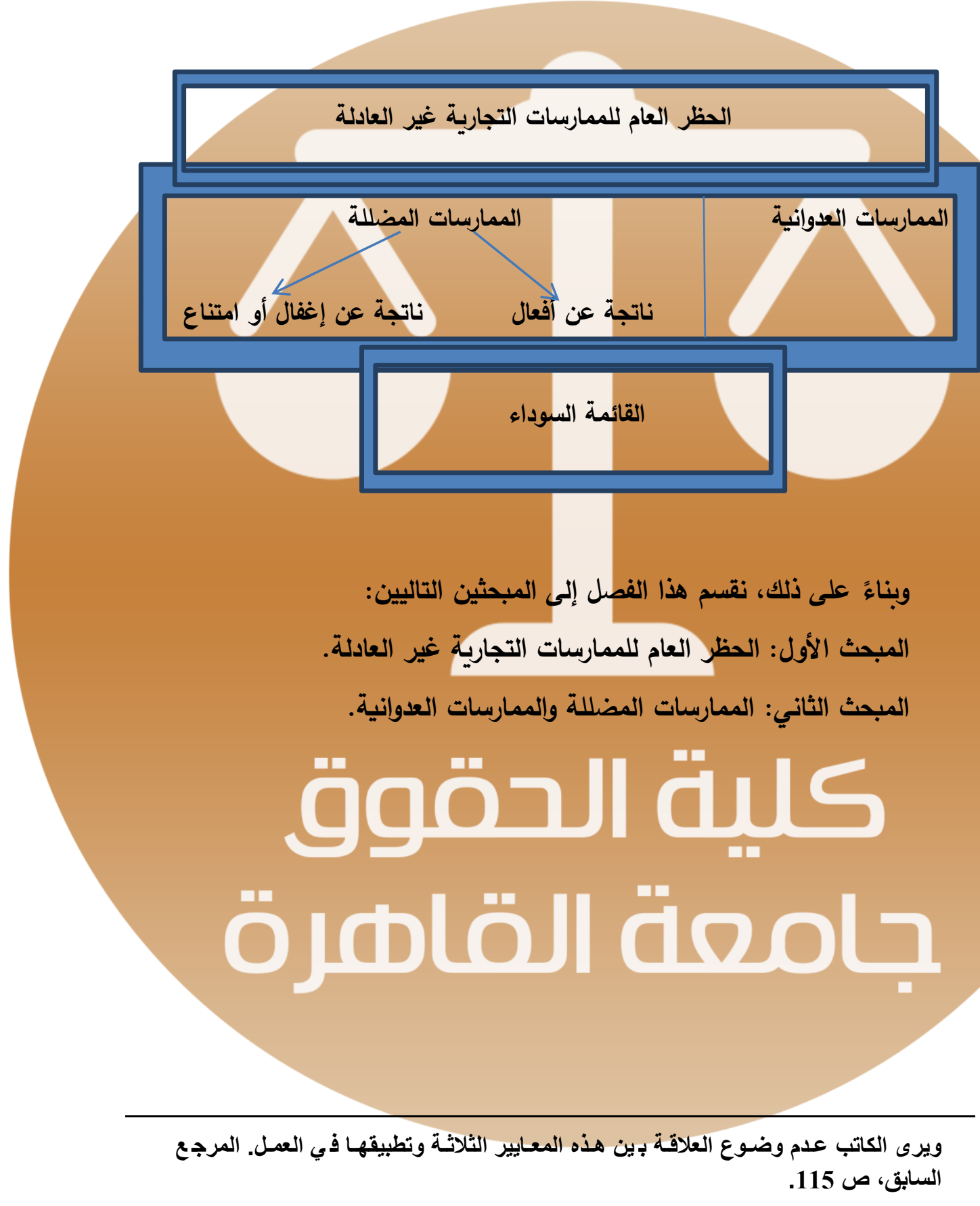


مجلة القانون والاقتصاد - ملحق خاص بمناسبة مرور مائة وخمسين عام

على إنثاء كلية الحقوق - جامعة القاهرة - العدد (الثانى والتسعون)

\section{المبحث الأول}

الهنt العام للمشمارسات التجارية فير العادلة

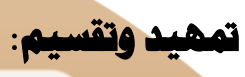

يتضمن التوجيـه الأوروبـي حظرًا عامَّا للممارسـات التجاريـة غيـر العادلـة. 1

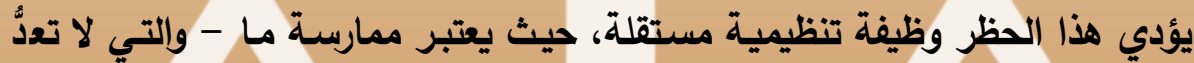

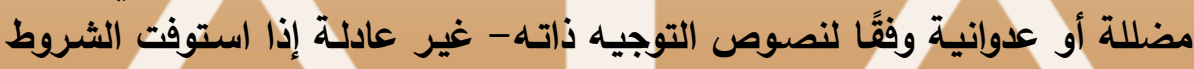

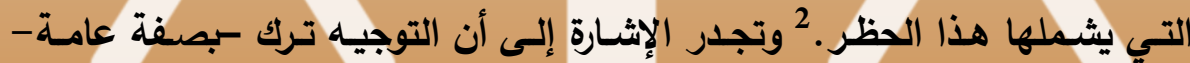

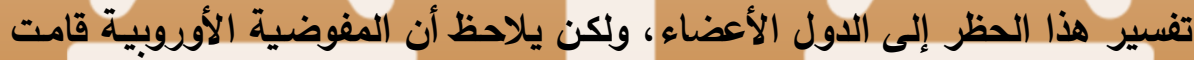
بصياغة إرشادات عامة للتوجيه؛ وذلك لضمان وتدعيم التفسير الموحد لنصوصه. 3 وفي حالـة وصف ممارسـةٍ مـا بأنها غير عادلـة، فإنها تعتبر محظورة وفقًا

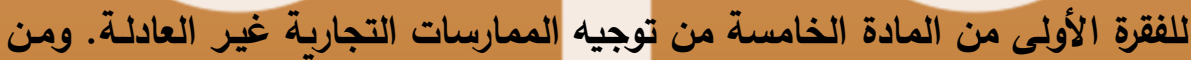

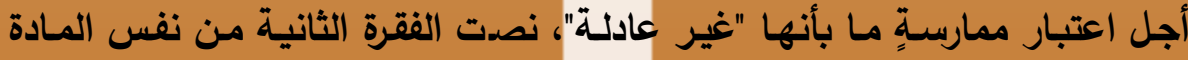

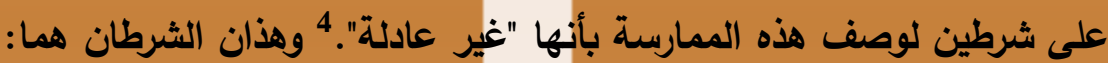

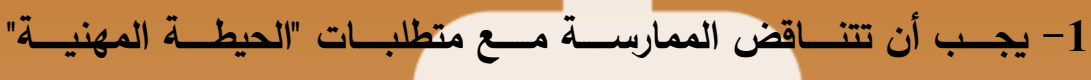
professional diligence

2- يجب أن تشوه distort- أو من المحتمل أن تشوه - الممارسة بطريقة

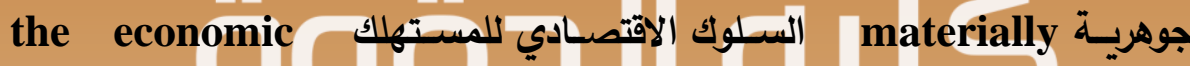
behavior of consumer الذي تصل إليه هذه الممارسة أو الموجهة إليه هذه لإنه

1 فيما يتعلق بالتطور و الخلفية التاريخية لهذا الحظر العام، انظر: Leistner, op. cit., pp.158-159.

Abbamonte, op. cit., p. 704; Collins, op. cit., p. 97; and Reilly, op. cit., pp. 114- 115.

: 3

Duivenvoorde, op. cit., p. 16.

: 4

Collins, op. cit., p. 98. 
الممارســة، أو للعضـو العـادي في مجموعـة مـن الحسالات التـي يـتم فيهـا توجيـه الممارسة التجارية إلى مجموعة معينة من المستهلكين. وبناءً على ذلك، نقسم هذا المبحث إلى مطلبين:

المطلب الأول: ماهية الحظر العام للممارسات التجارية غير العادلة.

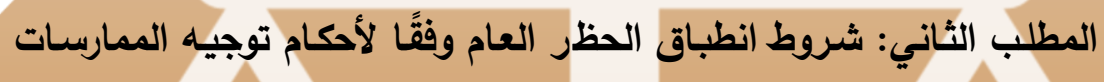

"1. Unfair commercial practices shall be prohibited.

2. A commercial practice shall be unfair if:

(a) it is contrary to the requirements of professional diligence, and

(b) it materially distorts or is likely to materially distort the economic behaviour with regard to the product of the average consumer whom it reaches or to whom it is addressed, or of the average member of the group when a commercial practice is directed to a particular group of consumers.

3. Commercial practices which are likely to materially distort the economic behaviour only of a clearly identifiable group of consumers who are particularly vulnerable to the practice or the underlying product because of their mental or physical infirmity, age or credulity in a way which the trader could reasonably be expected to foresee, shall be assessed from the perspective of the average member of that group. This is without prejudice to the common and legitimate advertising practice of making exaggerated statements or statements which are not meant to be taken literally. 11.6.2005 EN Official Journal of the European Union L 149/27 
مجلة القانون والاقتصاد - ملحق خاص بمناسبة مرور مائة وخمسين عام

على إنشاء كلية الحقوق - جامعة القاهرة - العدد (الثانى والتسعون)

ويتضمن الحظر العام للممارسـات التجاريـة غير العادلـة وظيفة تنظيميـة مستقلة،

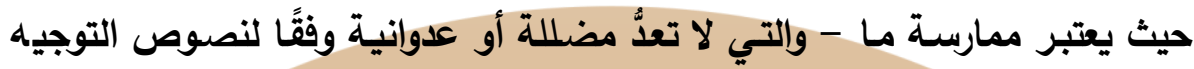

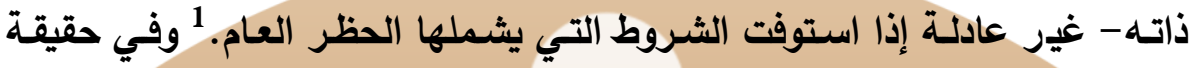

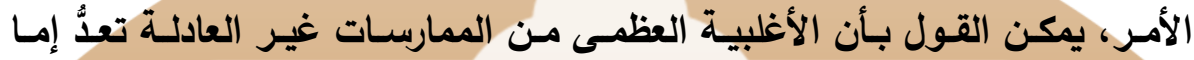

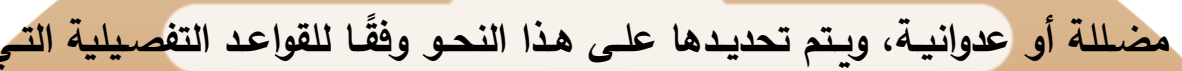

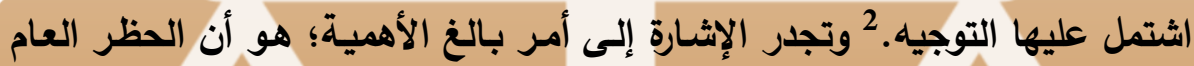

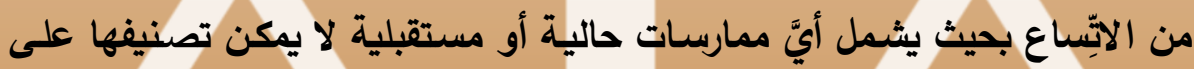

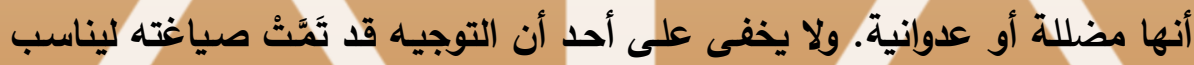

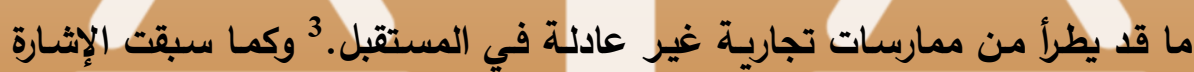

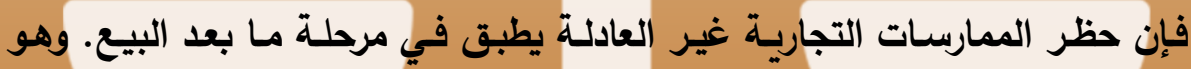
يسري أيضًا على الممارسات التي قد تقع خلاتل المرحلة الترويجية.

4. In particular, commercial practices shall be unfair which: (a) are misleading as set out in Articles 6 and 7, or (b) are aggressive as set out in Articles 8 and 9. 5. Annex I contains the list of those commercial practices which shall in all circumstances be regarded as unfair. The same single list shall apply in all Member States and may only be modified by revision of this Directive."

Abbamonte, op. cit., p. 704; Collins, op. cit., p. 97; and Reilly, op. cit., pp. 114- 115.

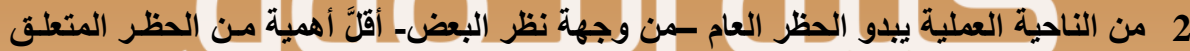

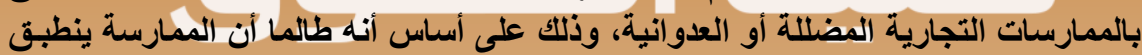

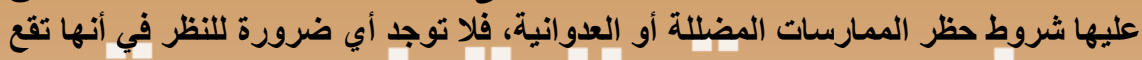

Willem H. Van Boom, Amandine Garde and Orkun Akseli, 'Introduction' in Willem H. Van Boom, Amandine Garde and Orkun Akseli, The European Unfair Commercial Practices Directive: Impact, Enforcement Strategies and National Legal Systems (The UK: Routledge Publishing, 2016), pp. 2-3.

Abbamonte, op. cit., p. 704. 3 
وتؤكد الفقرة الأولى من المادة الخامسة من التوجيه على حظر "الممارسـات

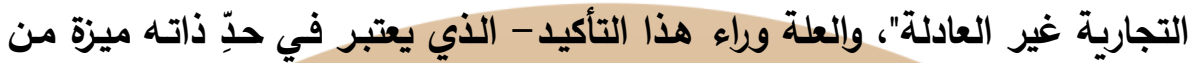

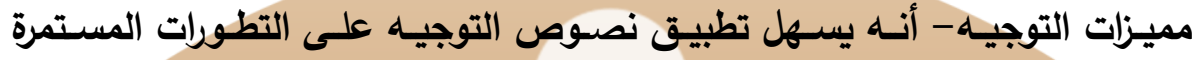

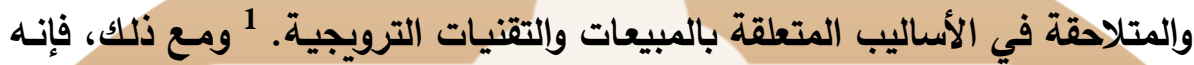

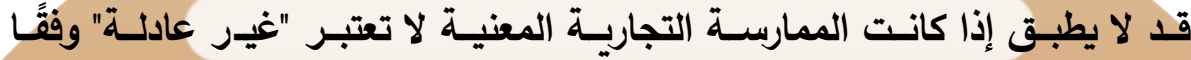

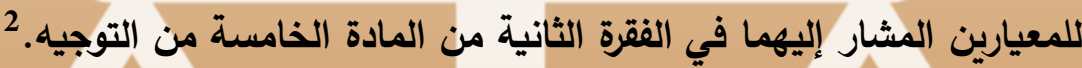
وبالنظر إلى ظهور ممارسـات تجاريـة جديدة كل يوم، فإن هذا يمثل تحديًا

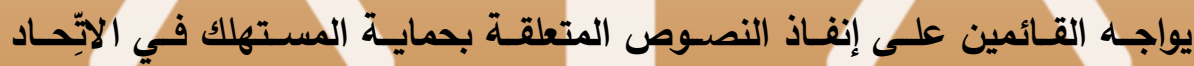

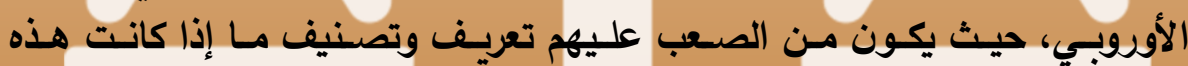

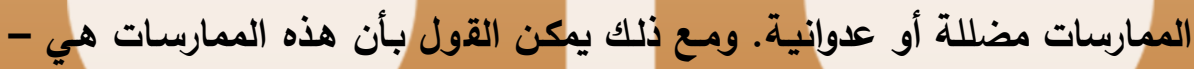

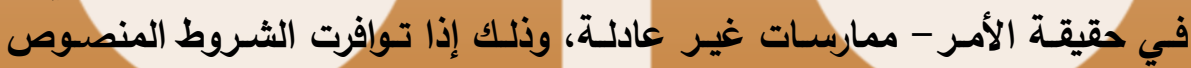
عليها في التوجيه. وأخيرًا، فإن التوجيه يحتوي على قائمـة سوداء شاملة للممارسـات التي من

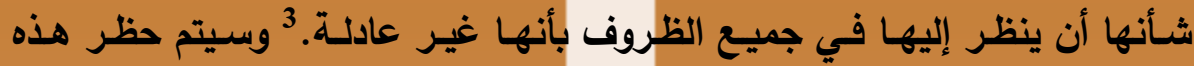

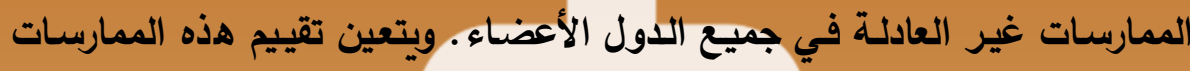

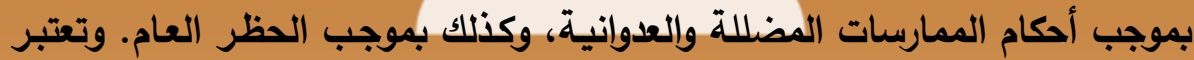

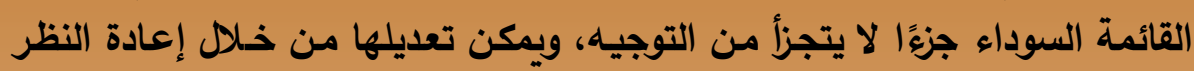

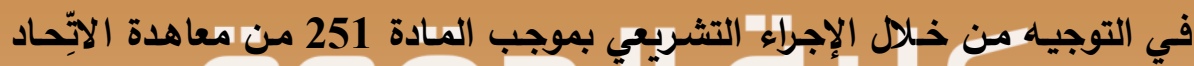

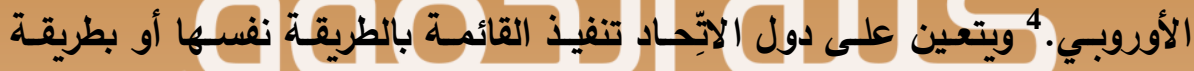

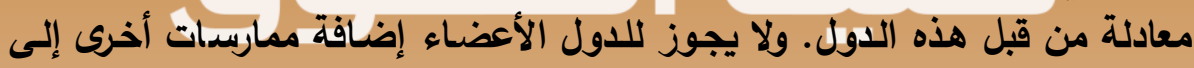

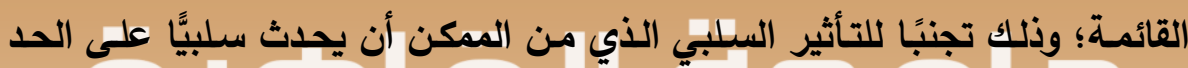

Poncibo and Incardona, op. cit., p. 320.

1 انظر المرجع السابق. 2 انظر المرجع السابق. 3 انظر الملحق رقم 1 للتوجيه.

Abbamonte, op. cit., p. 704. 
مجلة القانون والاقتصاد - ملحق خاص بمناسبة مرور مائة وخمسين عام

على إنثاء كلية الحقوق - جامعة القاهرة - العدد (الثانى والتسعون)

الأقصى للمواءمـة والتقريب الذي أدخله التوجيه، وأيضًا تجنبًا لعدم تحقيق هدف

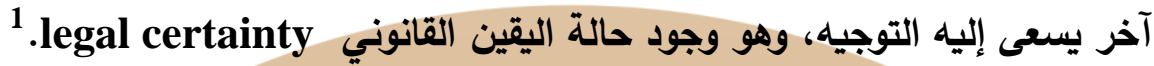

$$
\text { الألب الثاني }
$$

شورط انطباق المظر العام ونقا لأمكام توجيه الممارسات التجارية فير العادلة

وفقًا للفقرة الأولى من المـادة الخامسـة من توجيه الممارستات التجاربـة غير

العادلة، فإن كل ممارسـة تتصف بهذه الصففة تعتبر محظورة.

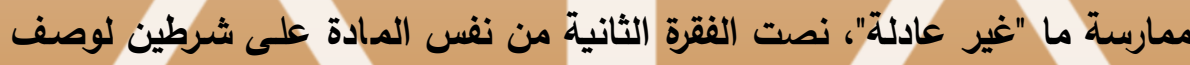

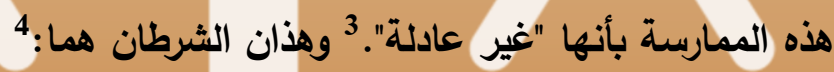

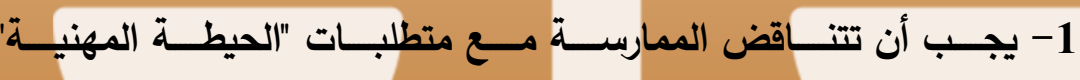

- professional diligence

2- يجب أن تشوه distort- أو من المحتمل أن تشوه - الممارسة بطريقة

1

2 ويجري نص هذه الفقرة باللغة الإنجليزية على النحو التالي:

"1. Unfair commercial practices shall be prohibited."

"2. A commercial practice shall be unfair if:

3 ويجري نص هذه الفقرة باللغة الإنجليزية على النحو التالي:

(a) it is contrary to the requirements of professional diligence, and

(b) it materially distorts or is likely to materially distort the economic behaviour with regard to the product of the average consumer whom it reaches or to whom it is addressed, or of the average member of the group when a commercial practice is directed to a particular group of consumers."

Anna

G. 4

Unfair Commercial Practices Directive and the UK Consumer

Protection from Unfair Trading Regulations: A Possible Conceptual Convergence of General, Flexible European Standards and English Law Concepts Relevant to Fairness in the EU Context of Consumer Protection.' Available at:

http://papers.ssrn.com/sol3/papers.cfm?abstract id=1099309. تم الاطِّلاع على الموقع بتّاريخ 31 مايو 2016. 
the economic السـلوك الاقتصـادي للمسـتهلك materially behavior of consumer

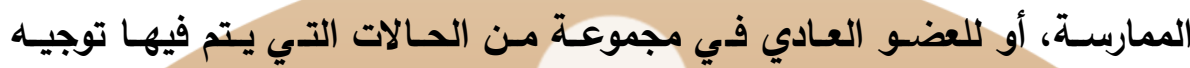
الممارسة التجارية إلى مجموعة معينة من المستهاكين. وبنتناول هذين الثرطين في الفرعين التاليين: الفرع الأول: تناقض الممارسة مع معيار الصيطة المهنية. الفرع الثاني: التشويـه الجوهري للسلوك الاقتصادي للمستهلك.

\section{الغرع الأهمل}

\section{تناتض المهارسة همع معيار المسطة أو اليقظة المهنية}

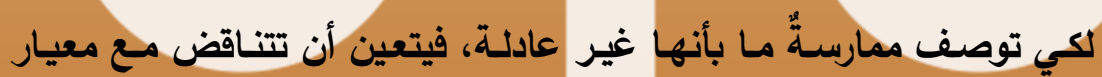

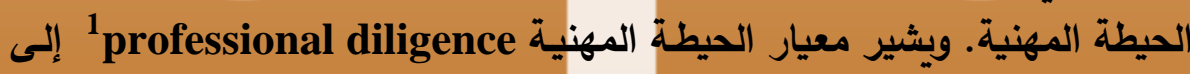

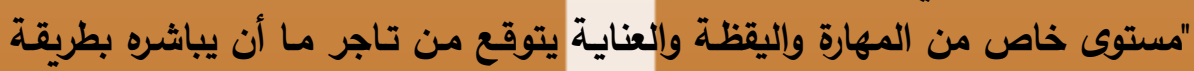

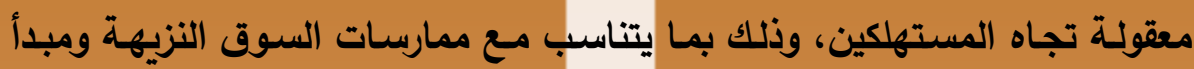

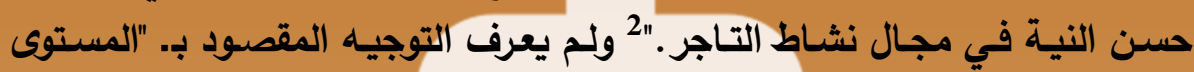

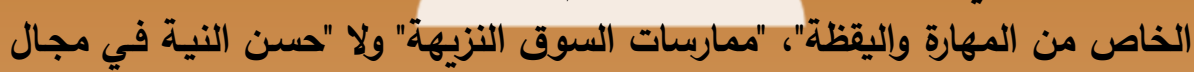
نشاط التاجر."3 وهذا يعتبر انتقادًا للتوجيه في حدِ ذاتـه. 4 1 ويعتبر مصطلح "professionals" ترجمـة ضعيفة للمفهوم الفرنسي الذي يشير إلى كل Collins, op. cit., p. 98.

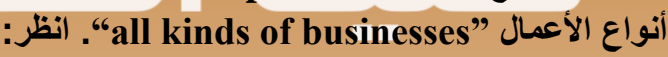
2 الفقرة (ح) من المادة الثانية. ويجري نصها باللغة الإنجليزية على النحو التالي: 98. "'professional diligence' means the standard of special skill and care which a trader may reasonably be expected to exercise towards consumers, commensurate with honest market practice and/or the general principle of good faith in the trader's field of activityy."

Collins, op. cit., p. 98; and Reilly, op. cit., p. 115.

Reilly, op. cit., p. 115. 
مجلة القانون والاقتصاد - ملحق خاص بمناسبة مرور مائة وخمسين عام

على إنشاء كلية الحقوق - جامعة القاهرة - العدد (الثانى والتسعون)

وبصفةٍ عامةٍ يمكن القول بأن معيار الحيطة المهنية يعكس مفهوم السلوك

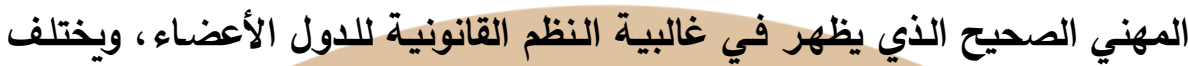
وفقًا لنوعية التجار المعنيين (فيختلف من مهنيين إلى شركةٍ مـا أو شركات صغيرة أو متوسطة الحجم أو حرفيين أو فنانين)، والسوق التي يعملون فيها والمستهلكين

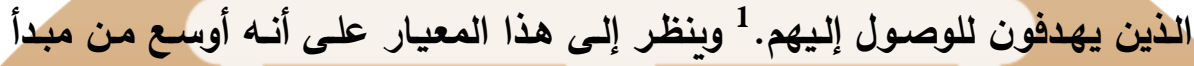

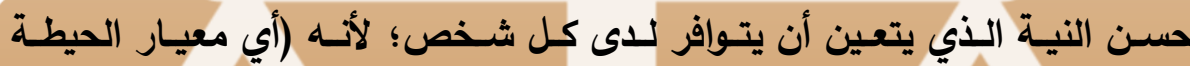

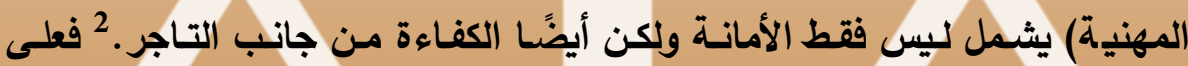

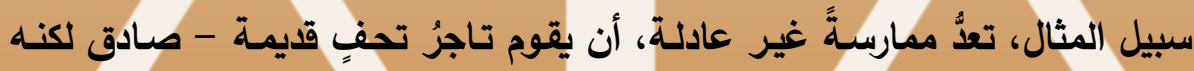

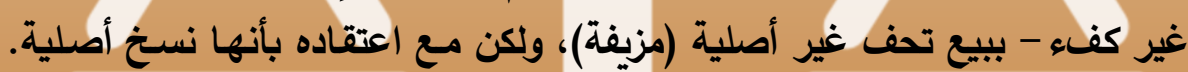
فهذا السلوك من جانب هذا التاجر لا يتفق مع متطلبات الحيطة المهنية.

ويعتبر مجال نشاط التاجر هو المعيار المرجعي لممارسـات السوق العادلة.

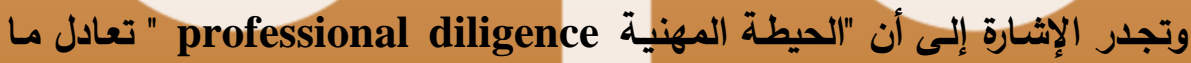

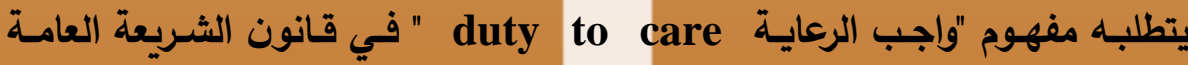
هو common law

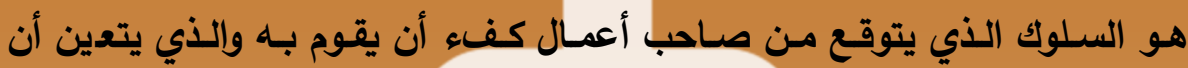

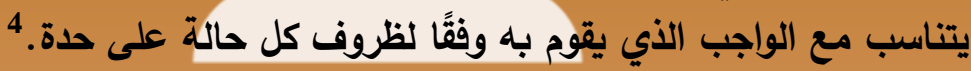

ويفترض أن يلتزم المهنيون بمعايير السلوك والممارسـات المـلأمــة المعتمدة

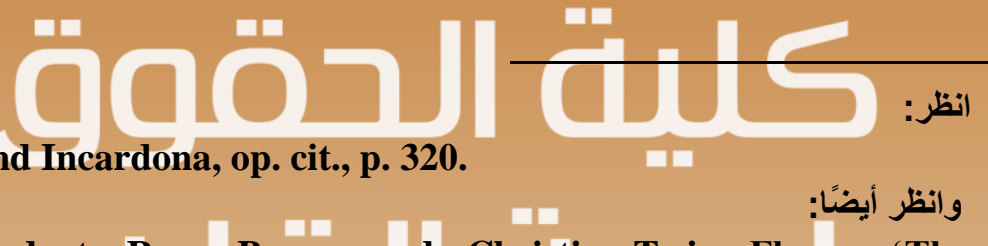

Robert Bradgate, Roger Brownword, Christian Twigg-Flesner, 'The Impact of Adopting a Duta to Trade Fairly', July 2003. Available at: http://webarchive.nationalarchives.gov.uk/20090609003228/http://ww w.berr.gov.uk/files/file32101.pdf

$$
\text { تم الاطِّلاع على الموقع بتاريخ } 31 \text { مايو } 2016 .
$$

2

Abbamonte, op. cit., p. 705.

3 انظر المرجع السابق.

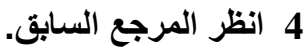


للديهر. حيـ يعتبر ذلكك مقياسًا للعنايـة والعيطـة الواجب مباشـتهـ. ومـن ناحيـة

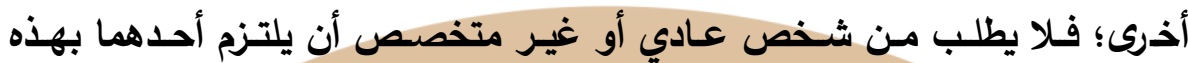

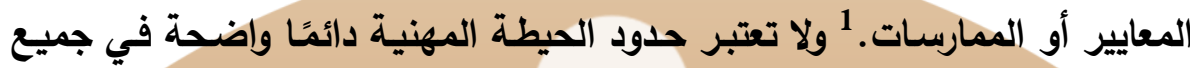

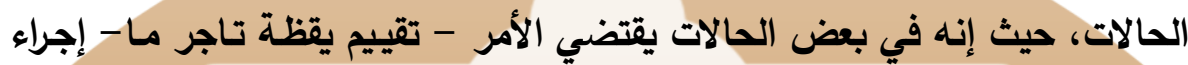

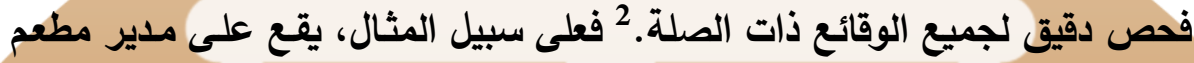

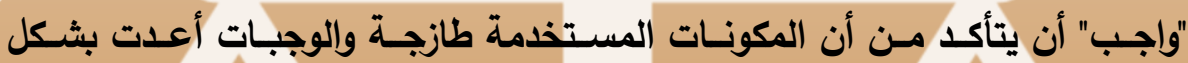

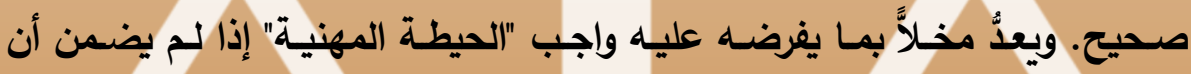

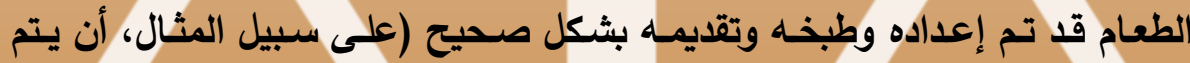

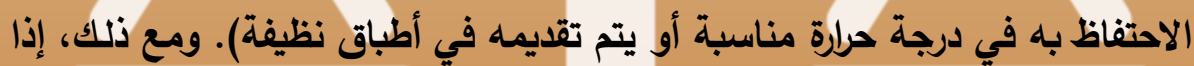

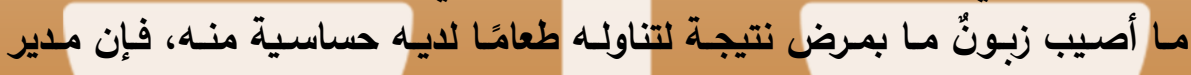

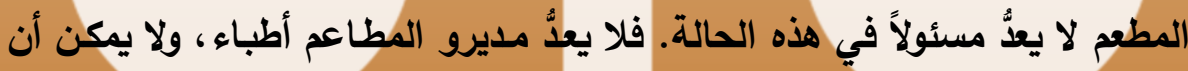
يكونوا مسئولين عن كل حادث يحدث لزبائن المطعم.

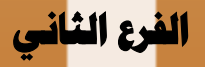

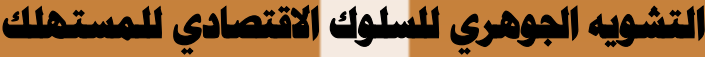

وفةًا لنصـوص توجيـه الممارسـات التجاريـة غيـر العادلـة، يشـترط أن تشـوه

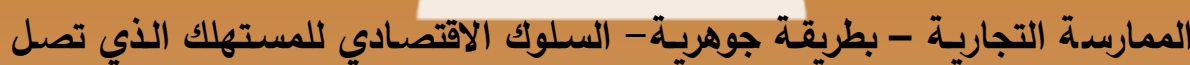

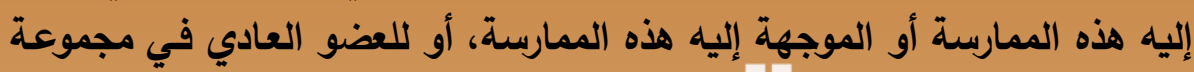

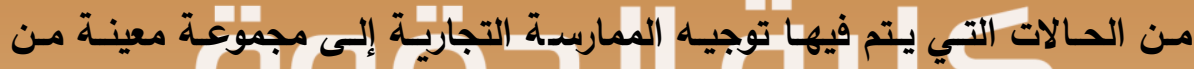
المسته|كين.

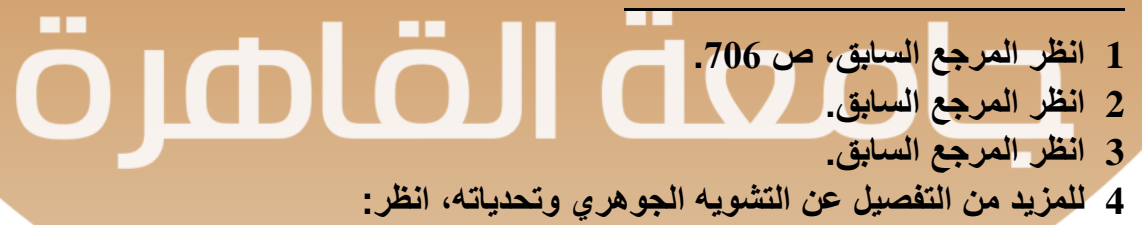

Avishalom Tor, 'Some Challenges Facing A Behaviorally Informed Approach To the Directive on Unfair Commercial Practices' in Tihamer Toth, Unfair Commercial Practices: The Long Road to Harmonized Law Enforcement (Budapest: Pazmany Press, 2013), p. 15. 
مجلة القانون والاقتصاد - ملحق خاص بمناسبة مرور مائة وخمسين عام

على إنثاء كلية الحقوق - جامعة القاهرة - العدد (الثانى والتسعون)

ويعرف التوجيه المقصود بـ "التشويه الجوهري للسلولك الاقتصادي للمستهلك"

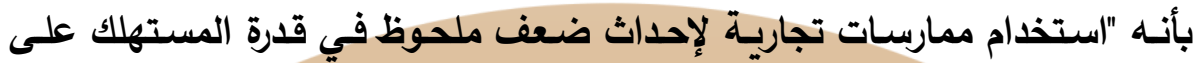

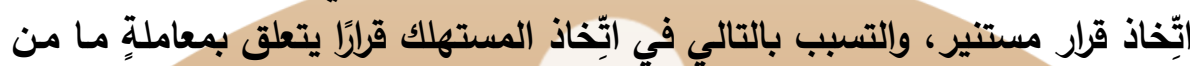

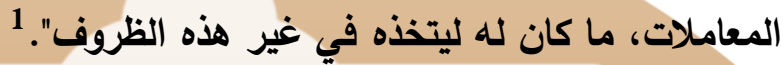

transactional وبعرف التوجيه أيضًا المقصود بـ "قرارًا يتعلق بمعاملـة

decision

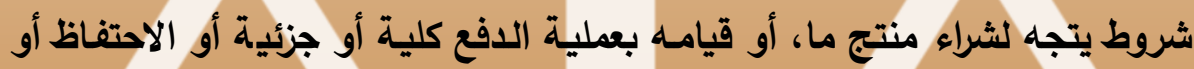

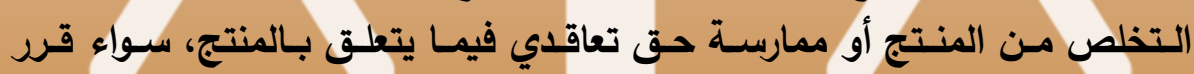

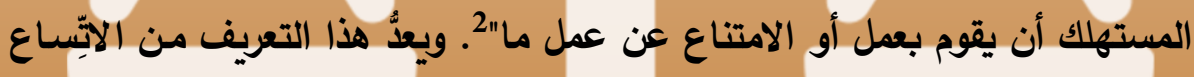

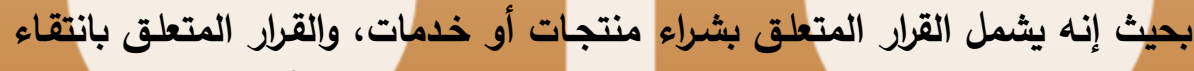

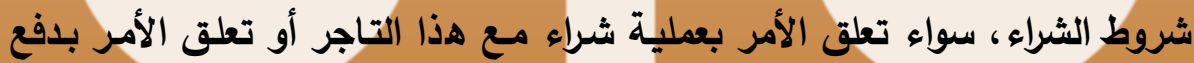

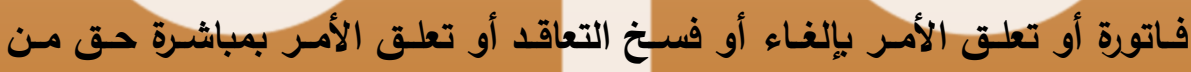

الحقوق التعاقدية.

وبناءً على ذلك، يتوافر التشويـه الجوهري لسلوك المستهلك، عندما يستخدم

1 الفقرة (0) من المادة الثانية من التوجيه. ويجري نصها باللغة الإنجليزية على النحو التالي:

(e) 'to materially distort the economic behaviour of consumers' means using a commercial practice to appreciably impair the consumer's ability to make an informed decision, thereby causing the consumer to take a transactional decision that he would not have taken otherwise.'

Avishalom Tor, op. cit., p. 15.

2 الفقرة (ك) من المادة الثانية من التوجيه. ويجري نصها باللغة الإنجليزية على النحو التالي:

'transactional decision' means any decision taken by a consumer concerning whether, how and on what terms to purchase, make payment in whole or in part for, retain or dispose of a product or to exercise a contractual right in relation to the product, whether the consumer decides to act or to refrain from acting;

Collins, op. cit., p. 101. 


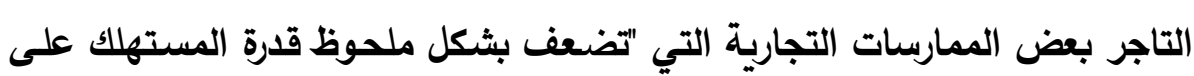

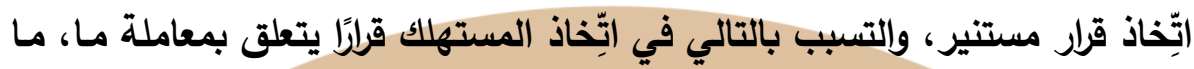

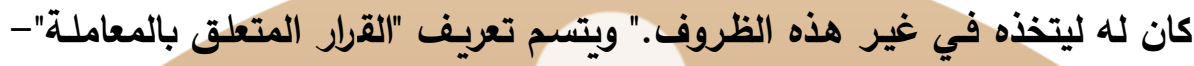

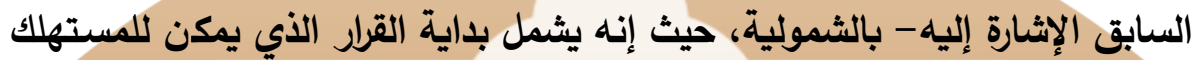

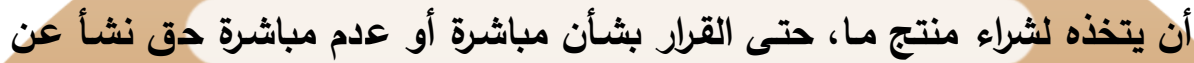

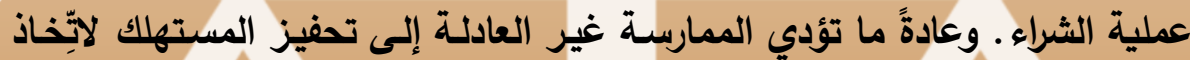
قرارٍ يتأسف عليه فيما بعد. 1

ويهدف "اختبار التثويـه الجوهري" إلى التحقق عما إذا كانت الممارسـة لديها

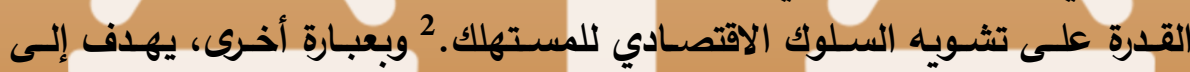

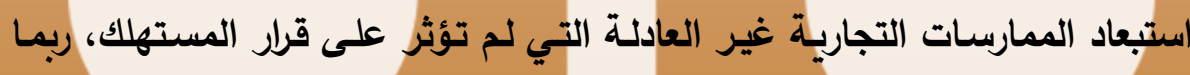

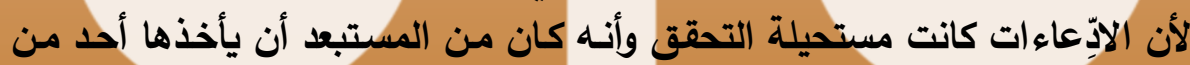

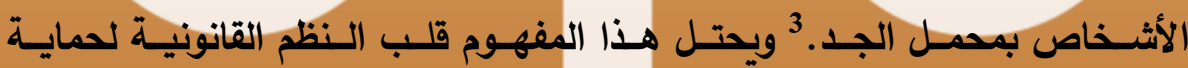

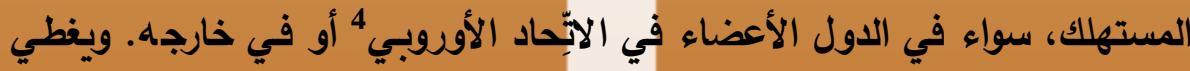

Poncibo and Incardona, op. cit., p. 321.

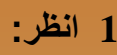

Abbamonte, op. cit., p. 706.

Collins, op. cit., p. 101.

4 وقد ذكر هذا المفهوم في التوجيه الأوروبي المتعلق بالإعلانات المقارنة في الفقرة الثانية مـن

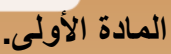

"Article 1(2) of the Misleading Advertising Directive defines misleading advertising as "any advertising which in any way, including its presentation, deceives or is likely to deceive the persons to whom it is addressed or whom it reaches and which, by reason of its deceptive nature, is likely to affect their economic behavior and for these reasons injures or is likely to injure competitors ...." Council Directive 84/450, art. 1(2), 1984 O.J. (L 250) 17 (EEC), as amended by Council Directive 97/55, 1997 O.J. (L 290) 18 (EC).

Abbamonte, op. cit., p. 706. انظر: 
مجلة القانون والاقتصاد - ملحق خاص بمناسبة مرور مائة وخمسين عام

على إنشاء كلية الحقوق - جامعة القاهرة - العدد (الثانى والتسعون)

البيان الفيدرالي الأمريكي المتعلق بالفش والخداع أيضًا الممارسـات التجاريـة غير

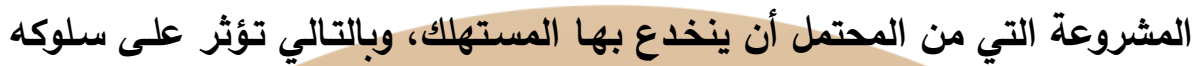
الاقتصادي.

والعلـة مدن وراء اعتبـار هذه الممارسداتِ ممارسـاتٍ غيـز عادلـة في معظم

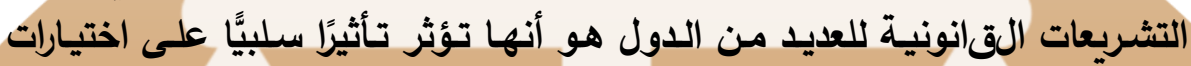

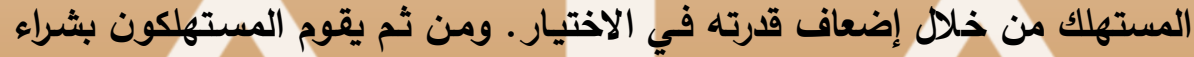

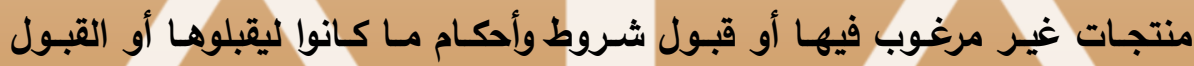

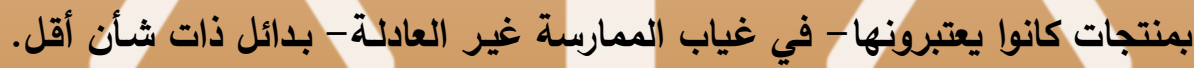

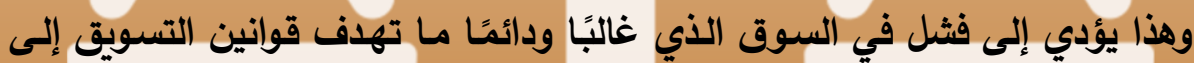
معالجته.

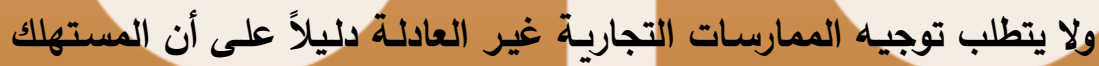

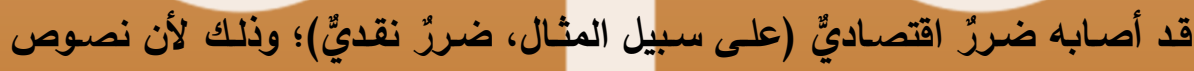
التوجيه تتطلب فقط احتمالية تشويـه السلوك الاقتصادي للمستهالك.

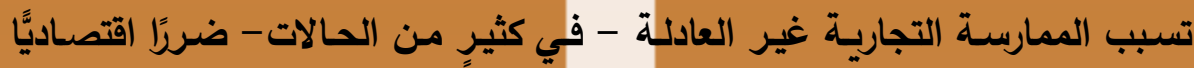

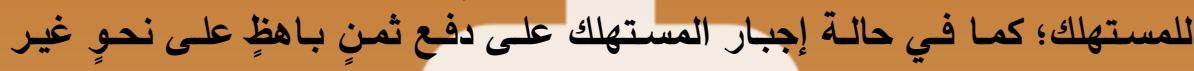

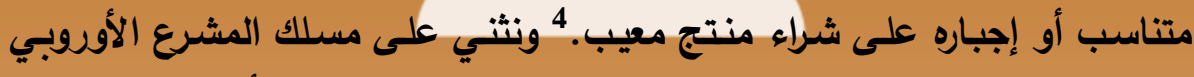

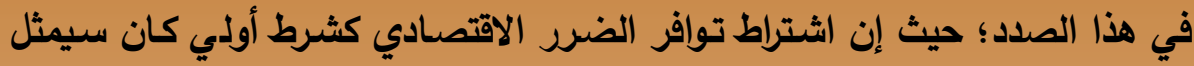

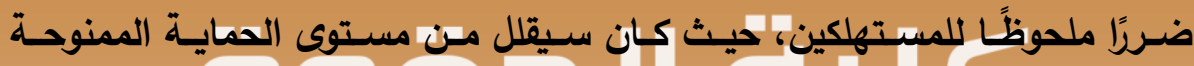

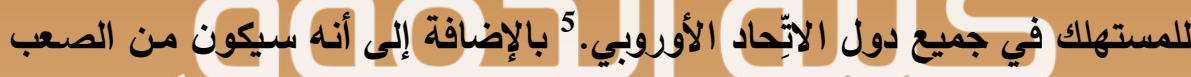
اللغاية - في معظم الحالات- - إثبات وتحديد الخسائر المالية.

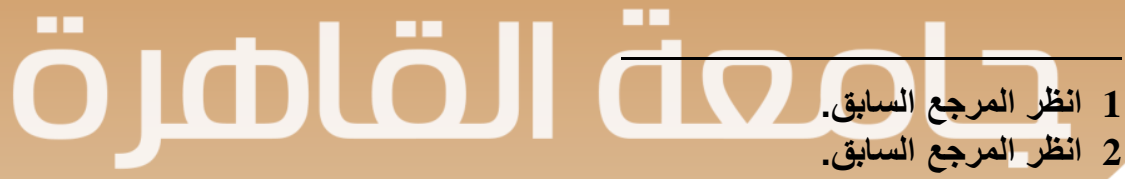
: 3

Collins, op. cit., p. 101.

Abbamonte, op. cit., p. 706.

4 انظر أيضًا: 5 6 
الخلاصة أنه في جميع الأحوال، يمكن اعتبار ممارسةٍ ما بأنها ممارسـة غير

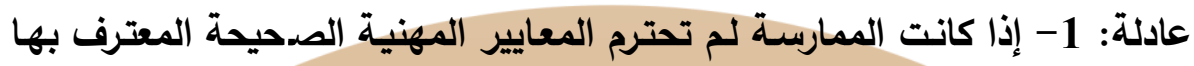

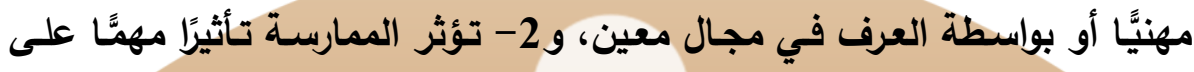

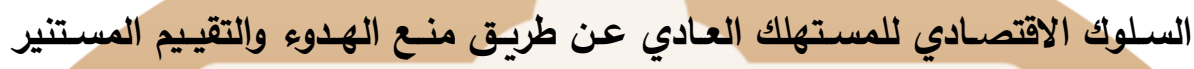
بثأن قرار أو معاملة تجارية. 1 ويجب التـكير بـأن هـنين المعيـارين "واجب الميطـة المهنيـة" و "التشـويـه

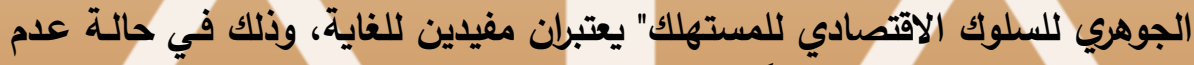

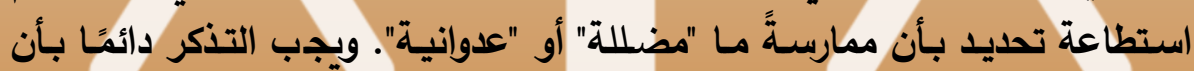

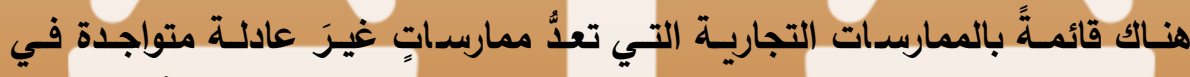

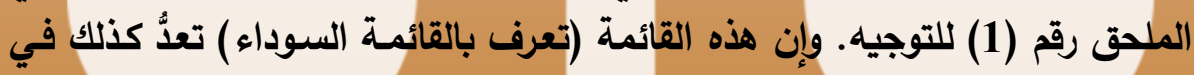
حِّ ذاتها، أي بصرف النظر عن البحث عن توافر أيّ معايير أو أدلة. 2

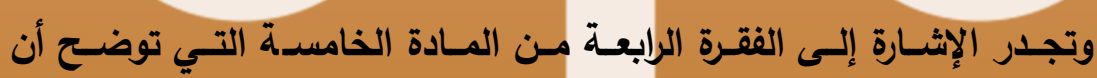

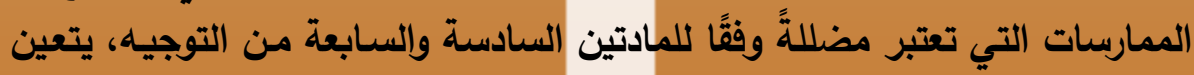

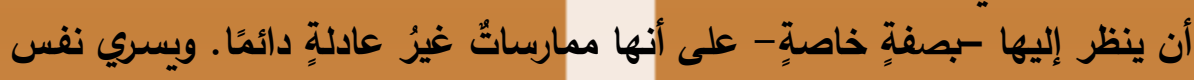

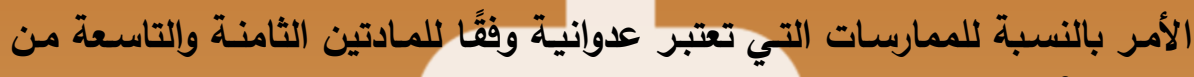

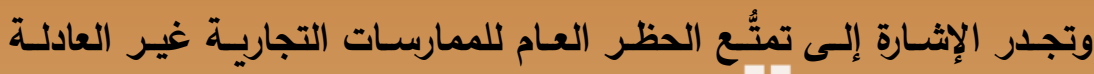

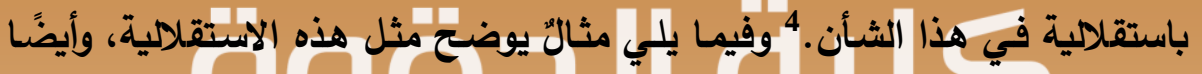

Abbamonte, op. cit., p. 706; and Collins, op. cit., p. 102.

Poncibo and Incardona, op. cit., p. 321. 2 انظر الفقرة الخامسة من المادة الخامسة من التوجيه. وانظر أيضًا:

Poncibo and Incardona, op. cit., p. 321. 3 ويجري نص هذه الفقرة باللغة الإنجليزية على النحو التالي:

“4. In particular, commercial practices shall be unfair which: (a) are misleading as set out in Articles 6 and 7, or (b) are aggressive as set out in Articles 8 and 9." 
مجلة القانون والاقتصاد - ملحق خاص بمناسبة مرور مائة وخمسين عام

على إنشاء كلية الحقوق - جامعة القاهرة - العدد (الثانى والتسعون)

الكيفية التي يمكن أن يعمل من خلالهها الحظر العام في الواقع. من المتفق عليه

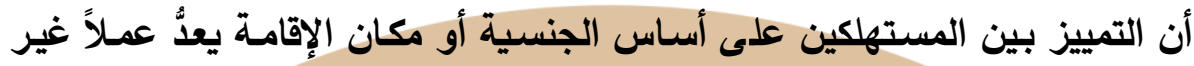

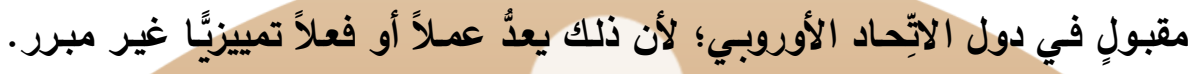

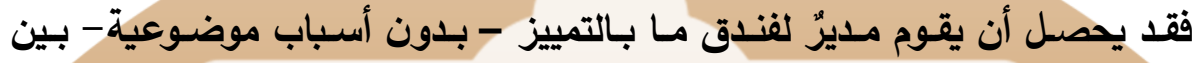

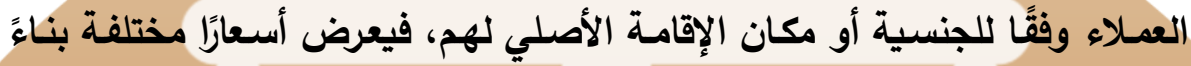

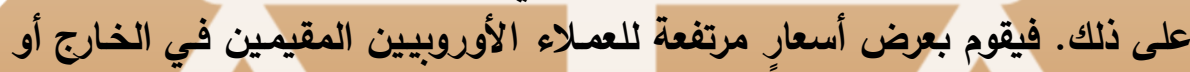

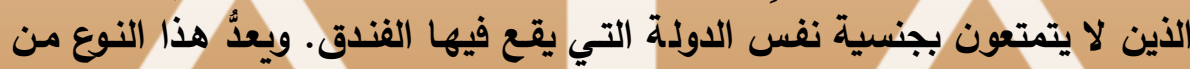
السلوك مخالفًا للمعايير التي يتضمنها الحظر العام للأسباب التالية:

أ) لا يمكن اعتبار الرفض غير المبرر لبيع أو التمييز بين العملاء بناءٌ على مئى

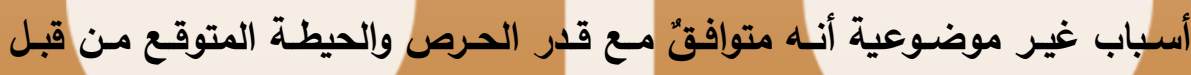

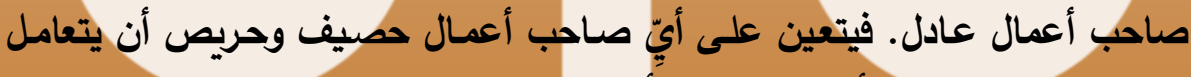

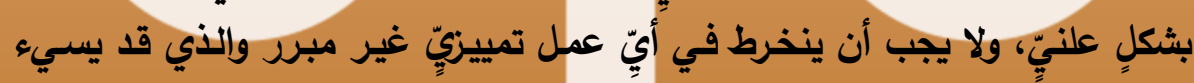

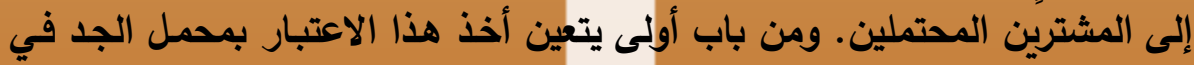

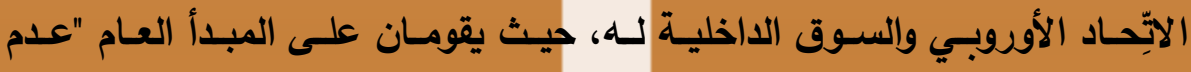

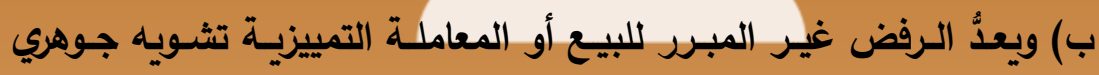

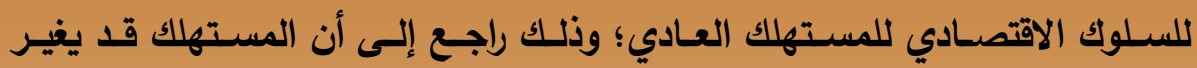

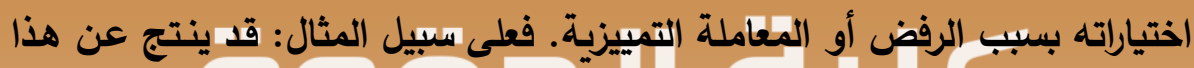

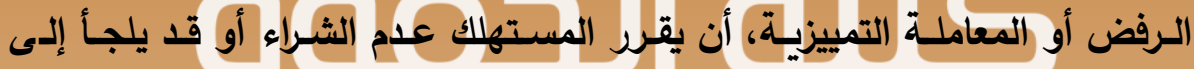

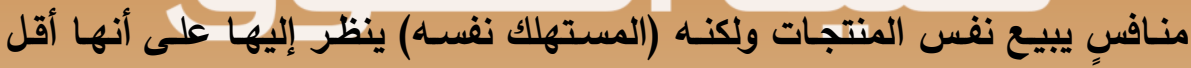

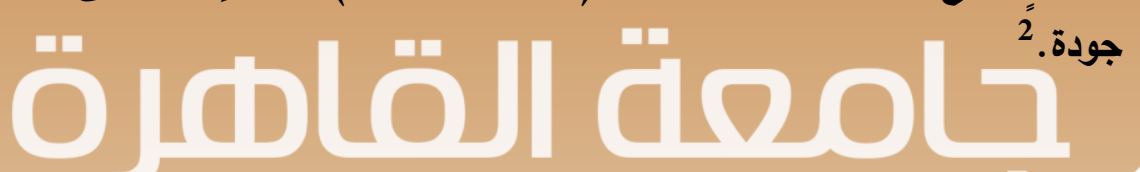

Abbamonte, op. cit., p. 709.

1 انظر المادة 12 من اتفاقية الاتِّاد الأوروبي. وبالنسبة للعديد من القضايا المتعلقة بمبدأ عدم

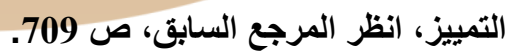


البمث الثناني

\section{المارسات التمارية الآلالة والعدوانية}

\section{تمهميد وتقشسيم:}

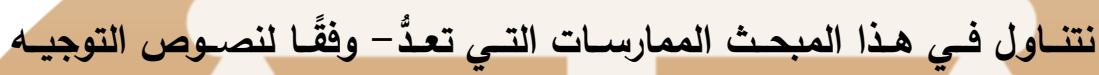

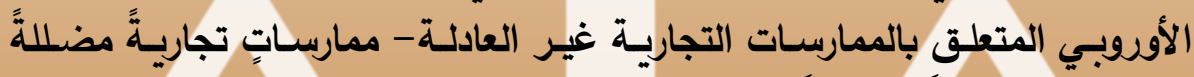

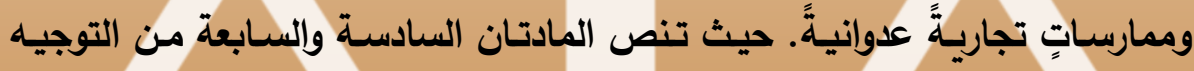

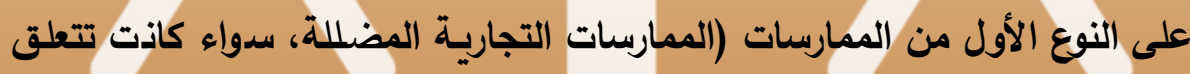

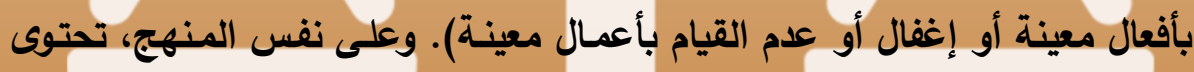

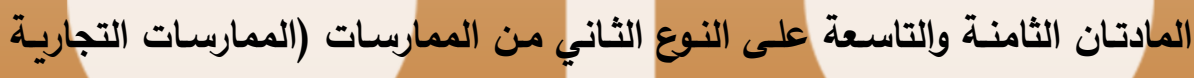

وبناءً على ذلك، نقسم هذا المبحث إلى المطلبين التاليين:

المطلب الأول: الممارسات التجارية المضللة.

المطاب الثاني: الممارسات التجاريـة العدوانية.

$$
\text { |لإلب الأول }
$$

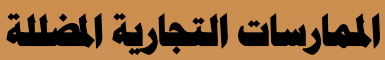

\section{Misleading Commercial Practices}

تضمن التوجيـه - فيمـا يتعلق بالممارسـات التجاريـة المضلالة - نوعين من

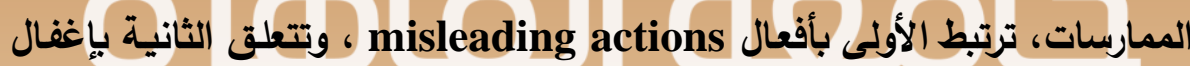

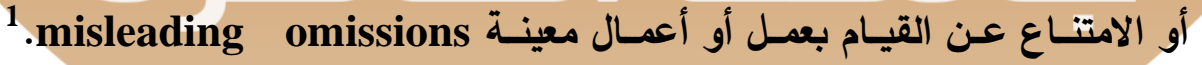

1 فيما يتعلق بالخلفية التاريخية لحظر الممارسات التجارية المضلاة في التوجيه، انظر: Matthias Leistner, op. cit., pp.159- 163.

وفيما يتعلق بالممارسات التجارية غير المشروعة والإعلانات المضلاة، انظر بصفة خاصة: 
مجلة القانون والاقتصاد - ملحق خاص بمناسبة مرور مائة وخمسين عام

على إنثاء كلية الحقوق - جامعة القاهرة - العدد (الثانى والتسعون)

وبعبارة أخرى، يمكن تصسور وقوع الممارسـات التجاريـة المضللة بواسطة فعل أو عمأو

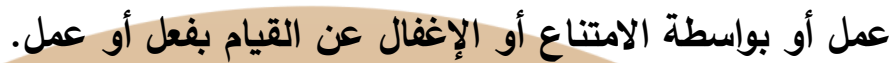

وسوف نتـاول هذين النوعين من الممارسـات التجاريـة المضللة في فرعين

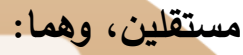

الفرع الأول: الممارسات التجارية المضللة التي تتعلق بأفعال معينة.

الفرع الثاني: الممارسـات التجاريـة المضـللة التي تتعلق بياغفـال أو عدم

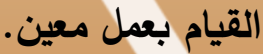

الفرع الأول

الممارسات التبارية الاذلالة التي قتعثق بأفعال معينة

تشير الفقرة الأولى من المادة السادسة من التوجيه إلى الممارسـات التجاريـة

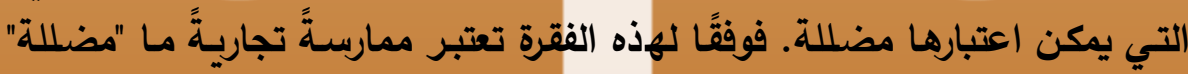

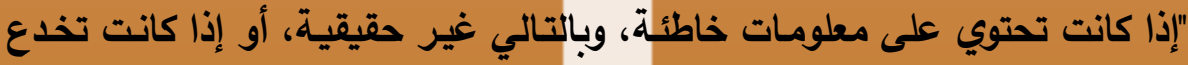

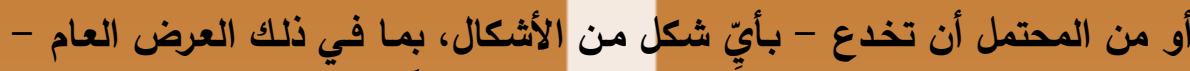

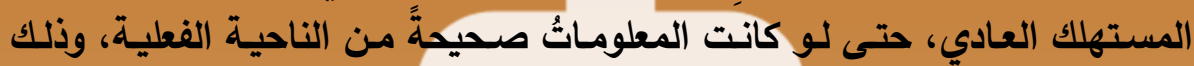

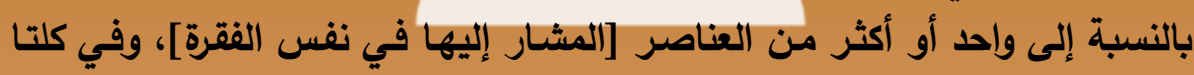

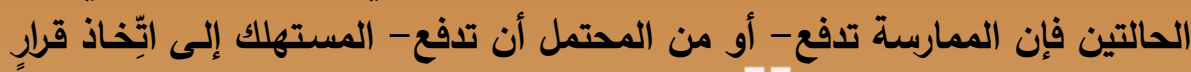

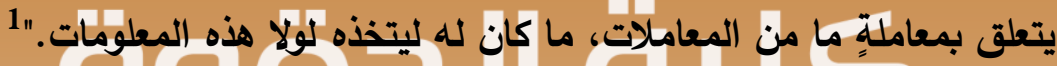

H.W. Micklitz, 'Unfair Commercial Practices and Misleading Advertising' in Hans-W. Micklitz, Norbert Reich and Peter Rott, Understanding EU Consumer Law (Oxford: Intersentia, 2009).

1 ويجري نص الفقرة الأولى من المادة السادسة من التوجيه باللغة الإنجليزية على النحو التالي:

"A commercial practice shall be regarded as misleading if it contains

false information and is therefore untruthful or in any way, including overall presentation, deceives or is likely to deceive the average consumer, even if the information is factually correct, in relation to one or more of the following elements, and in either case causes or is likely to cause him to take a transactional decision that he would not have taken otherwise..." 
وبنـاءً على ذلك، فبإن الممارسـات التجاريـة المضللة التي تتعلق بأفعال هي

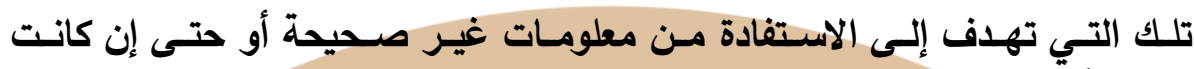

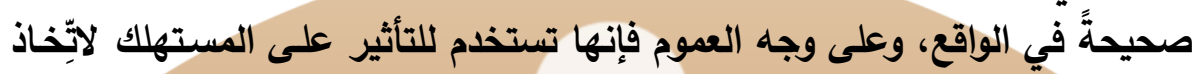

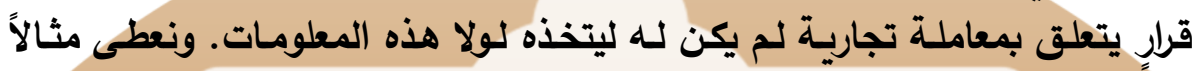

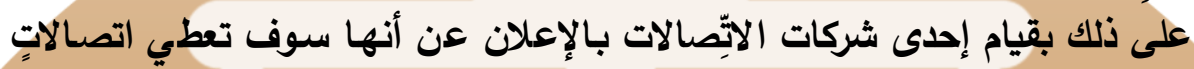

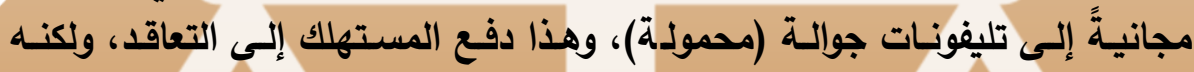

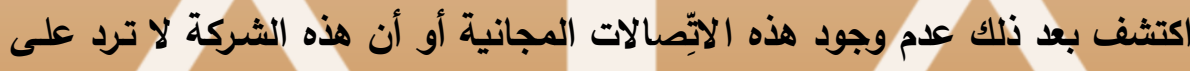

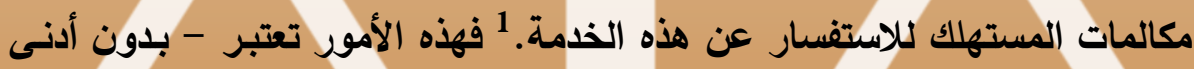

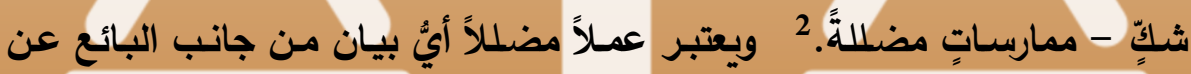
حقوق المستهلك فيما يتعلق بشكوى معينة، وذلك بعد إتمام عملية البيع. 3 وتجـدر الإثـارة إلى أن التعريـف الـوارد في التوجيـه للممارسـات التجاريـة

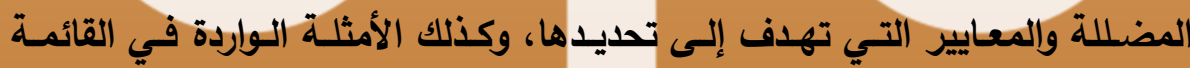

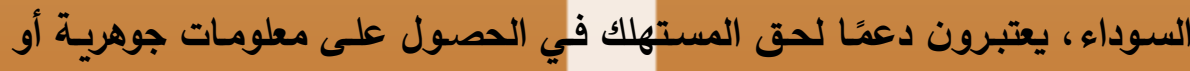

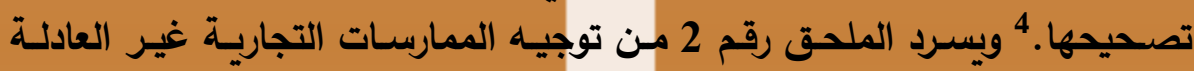

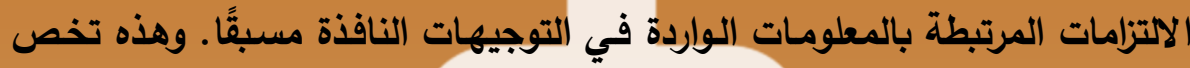
المعلومات المتعلقة بالإعلانات والآِّصالات التجارية.

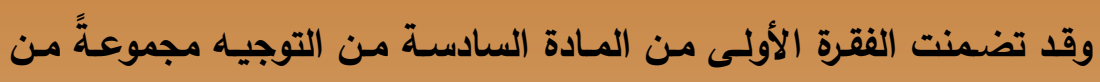
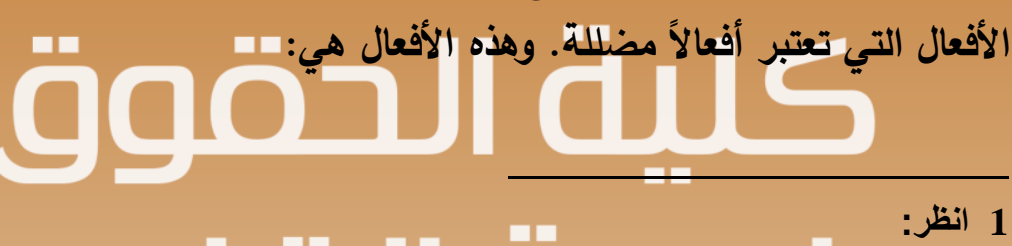

Reilly, op. cit., p. 116.

Collins, op. cit., p. 103.

4

S Haupt, 'An Economic Analysis of Consumer Protection Law', (2003) 11 German Law Journal.

Poncibo and Incardona, op. cit., p. 321. 
مجلة القانون والاقتصاد - ملحق خاص بمناسبة مرور مائة وخمسين عام

على إنثاء كلية الحقوق - جامعة القاهرة - العدد (الثانى والتسعون)

$$
\begin{aligned}
& \text { أ) وجود أو طبيعة المنتج. } \\
& \text { ب) خصائص المنتج.2 }
\end{aligned}
$$

ج) مـدى التزامـات التـاجر، أو دوافـع الممارســة التجاريـة، أو طبيعة عمليـة

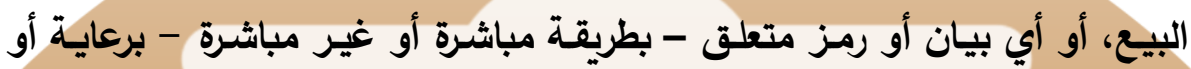
بموافقة من التاجر أو المنتج.

د) السعر أو حساب السعر أو وجود مزايا محددة ومتعلقة بالسعر.4 4 هـ) الحاجـة إلـى صـيانة أو قطـع غيـار أو اسـتبدال أو إصــلاح بشــأن

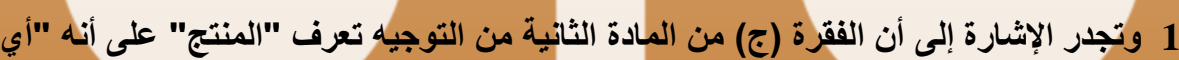

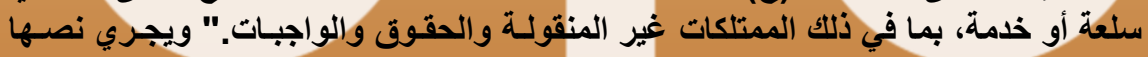
باللغة الإنجليزية على النحو التالي: بلى فليكات

“(c)'product' means any goods or service including immovable property, rights and obligations."

2 انظر الفقرة "ب" من الفقرة الأولى مـن المـادة السادسـة. ويجري نص هذه الفقرة باللفـة الإنجليزية على النحو التالي:

"The main characteristics of the product, such as its availability, benefits, risks, execution, composition, accessories, after sale customer assistance and complaint handling, method and date of manufacture or provision, delivery, fitness for purpose, usage, quantity, specification, geographical or commercial origin or the results to be expected from its use, or the results and material features of tests or checks carried out on the product."

3 انظر الفقرة (ج) من الفقرة الأولى من المادة السادسة من التوجيه. ويجري نص هذه الفقرة

"(c) the extent of the trader's commitments, the motives for the commercial practice and the nature of the sales process, any statement or symbol in relation to direct or indirect sponsorship or approval of the trader or the product."

4 انظر الفقرة (د) من الفقرة الأولى من المادة السادسة مـن التوجيه التـي يجري نصـها باللفـة

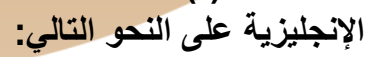

" (d) the price or the manner in which the price is calculated, or the existence of a specific price advantage." 
و) المعلومــات ذات الصـلة بالتـاجر أو وكيلـه، وتثــــل علـى سـبيل المثــال

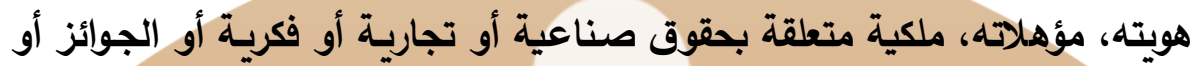

ز) حقوق المستهلكين والمخاطر التي قد يتكبدها. 3

ويعتبر - وفققًا لتوجيـه الممارسـات التجاربـة غير العادلـة- ممارسـةً تجاربـةً

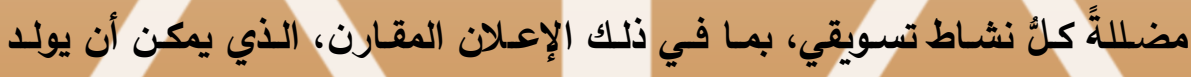

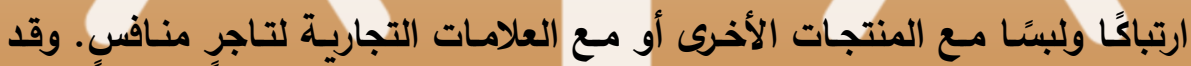

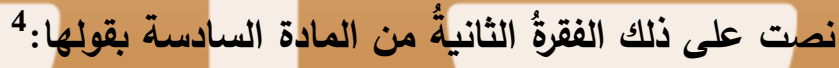

1 انظر الفقرة (ه) من الفقرة الأولى من المادة السادسـة مـن التوجيهـ التـي يجري نصـها باللفـة

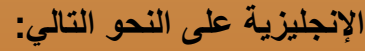

" (e) the need for a service, part, replacement or repair."

2 انظر الفقرة (و) من الفقرة الأولى من المادة السادسة مـن التوجيـه التي يجري نصـها باللغـة

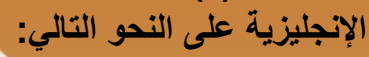

" (f) the nature, attributes and rights of the trader or his agent, such as his identity and assets, his qualifications, status, approval, affiliation or connection and ownership of industrial, commercial or intellectual property rights or his awards and distinctions."

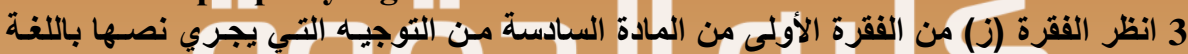
الإنجليزية على النحو التالي:

"(g) the consumer's rights, including the right to replacement or reimbursement under Directive 1999/44/EC of the European Parliament and of the Council of 25 May 1999 on certain aspects of the sale of consumer goods and associated guarantees (1), or the risks he may face."

$$
4 \text { ويجري نصها باللغة الإنجليزية على النحو التالي: }
$$

"2- A commercial practice shall also be regarded as misleading if, in its factual context, taking account of all its features and circumstances, it causes or is likely to cause the average consumer to take a transactional decision that he would not have taken otherwise, and it involves: 
مجلة القانون والاقتصاد - ملحق خاص بمناسبة مرور مائة وخمسين عام

على إنثاء كلية الحقوق - جامعة القاهرة - العدد (الثانى والتسعون)

"ويجب أيضًا اعتبـار ممارسـة تجاريـة مـا "مضـللة" إذا كانـت - في إطارهـا

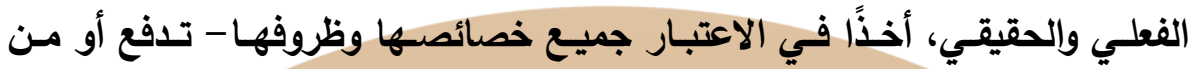

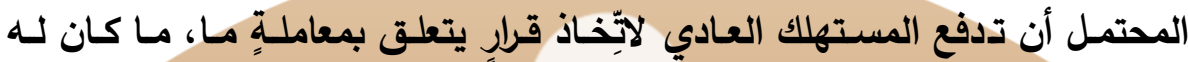

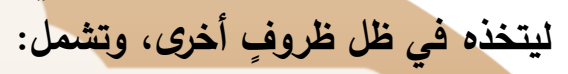

(أ) أي تسويق للمنتج، بمـا في ذلك الإعـلان المقارن، الذي يخلق التباسًا

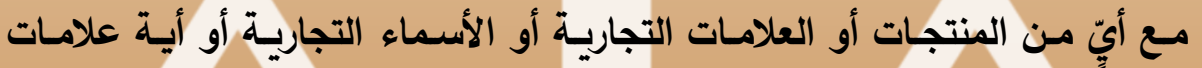

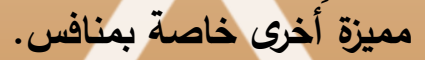

(ب) عدم الامتثال من قبل التاجر مع الاتزامـات الواردة في مدونات قواعد

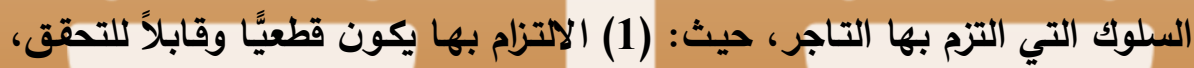

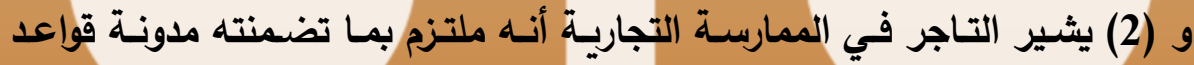

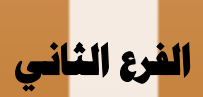

السلوك.

المارسات التجارية الاضلالة التي تمدث بإخفال أو عدم القيام بعمل معين

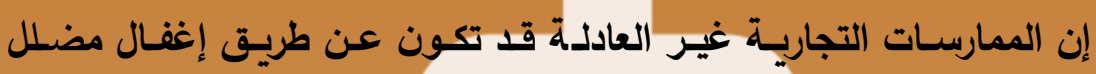

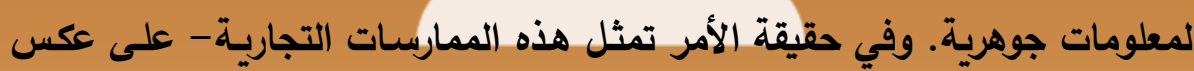

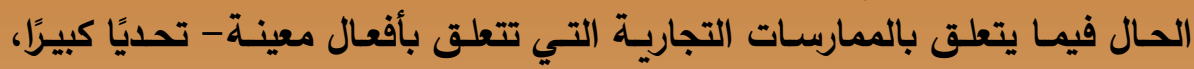

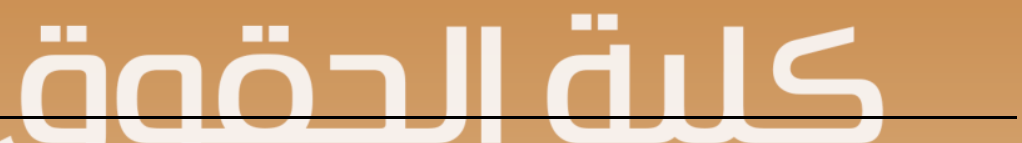

(a) any marketing of a product, including comparative advertising, which creates confusion with any products, trade marks, trade names or other distinguishing marks of a competitor;

(b) non-compliance by the trader with commitments contained in codes of conduct by which the trader has undertaken to be bound, where:

(i) the commitment is not aspirational but is firm and is capable of being verified,

and

(ii) the trader indicates in a commercial practice that he is bound by the code." 
حيث يصعب تحديدها تحديًا دقيقًا. 1وقد نصت على هذه الحالة المادة السـابعة من توجيه الممارسات التجارية غير العادلة.

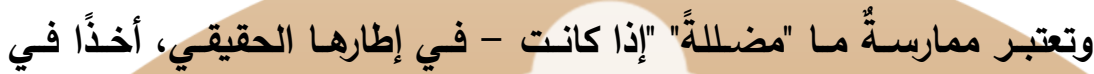

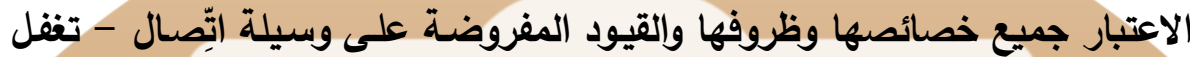

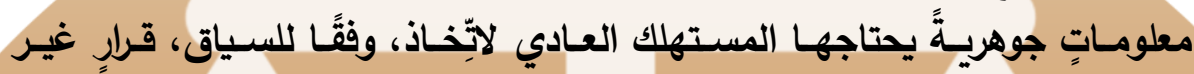

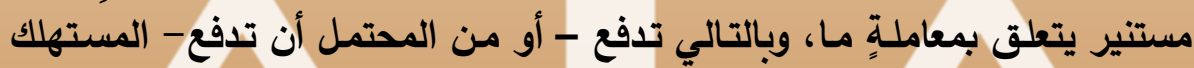

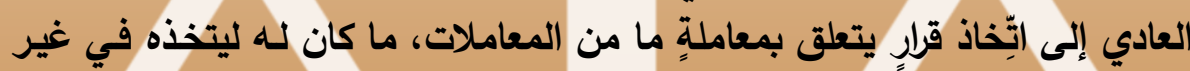
هذه الظروف. وقد تقع الممارسات التجاريـة "المضللة" عن طريق إخفاء معلومـات جوهربـة

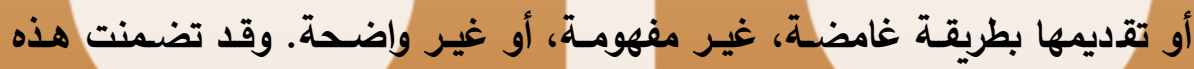

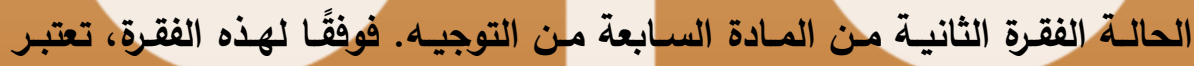

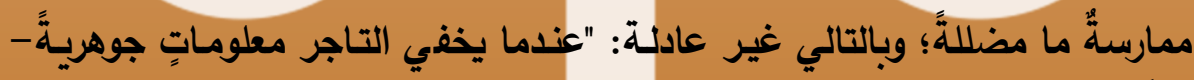

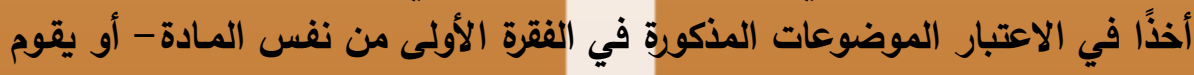

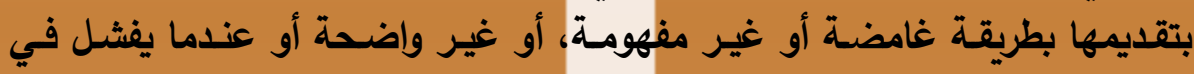

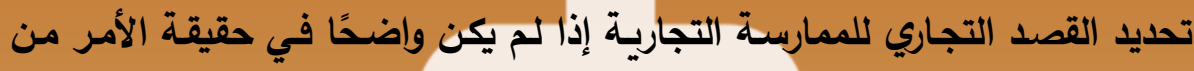

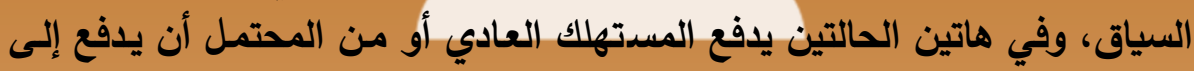

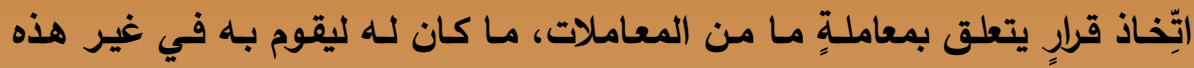

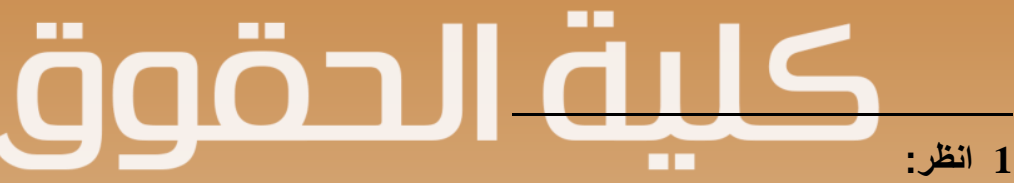

Collins, op. cit., p. 104.

2 انظر الفقرة الأولى من المادة السابعة من التوجيه. ويجزي نصها باللغة الإنجليزية على النحو . التالي:

"1. A commercial practice shall be regarded as misleading if, in its factual context, taking account of all its features and circumstances and the limitations of the communication medium, it omits material information that the average consumer needs, according to the context, to take an informed transactional decision and thereby causes or is likely to cause the average consumer to take a transactional decision that he would not have taken otherwise." 
مجلة القانون والاقتصاد - ملحق خاص بمناسبة مرور مائة وخمسين عام

على إنثاء كلية الحقوق - جامعة القاهرة - العدد (الثانى والتسعون)

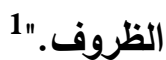

وفيما يتعلق بالدعوة إلى الشراء Invitation to purchase ، فقد أفرد

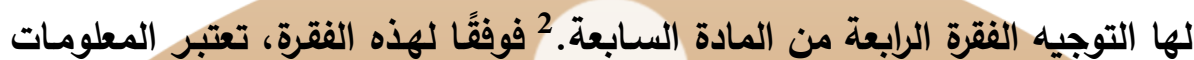

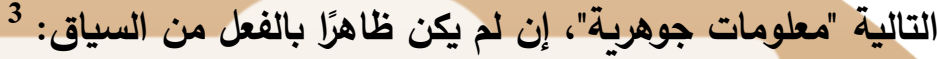

1 انظر الفقرة الثانية من المادة السابعة من التوجيه. ويجري نصها باللغة الإنجليزية على النحو

التالي:

"2. It shall also be regarded as a misleading omission when, taking account of the matters described in paragraph 1 , a trader hides or provides in an unclear, unintelligible, ambiguous or untimely manner such material information as referred to in that paragraph or fails to identify the commercial intent of the commercial practice if not already apparent from the context, and where, in either case, this causes or is likely to cause the average consumer to take a transactional decision that he would not have taken otherwise."

2

Willem H. Van Boom, Amandine Garde and Orkun Akseli, op. cit., p. 4. 3 انظر الفقرة الرابعة من المادة السابعة من التوجيه. ويجري نصها باللغة الإنجليزية على النحو

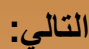

"4- In the case of an invitation to purchase, the following information shall be regarded as material, if not already apparent from the context:

(a) the main characteristics of the product, to an extent appropriate to the medium and the product;

(b) the geographical address and the identity of the trader, such as his trading name and, where applicable, the geographical address and the identity of the trader on whose behalf he is acting;

(c) the price inclusive of taxes, or where the nature of the product means that the price cannot reasonably be calculated in advance, the manner in which the price is calculated, as well as, where appropriate, all additional freight, delivery or postal charges or, where these charges cannot reasonably be calculated in advance, the fact that such additional charges may be payable; 
(ب) العنوان الجغرافي وهويـة التاجر، مثل: اسمه التجاري، وعند الاقتضـاء: العنوان الجغرافي وهوية التاجر الذي يمثله.

(ج) السـعر الذي يثدمل الضـرائب، وطربقـة حسـابه في حالـة مـا إذا كانـت

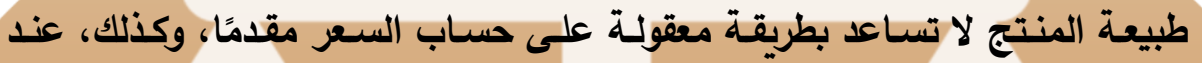

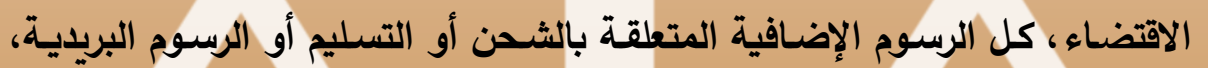

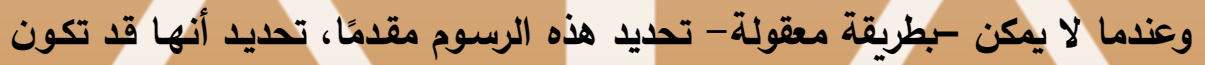
مستحقة الدفع.

(د) ترتيبات الدفع والتسليم والأداء وسياسـة التعامل مـع الثكوى، في حالـة الآتِفاق على عدم الالتزام بمتطلبات الحيطة المهنية.

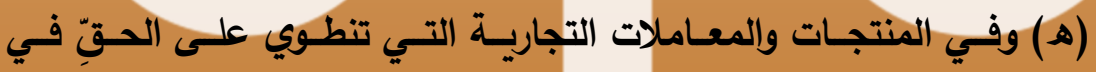

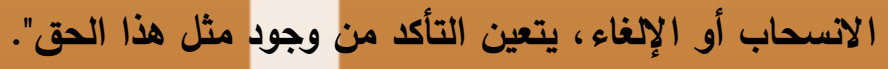

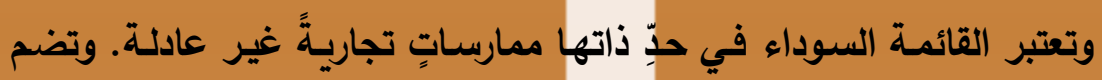

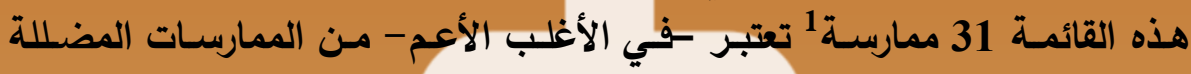

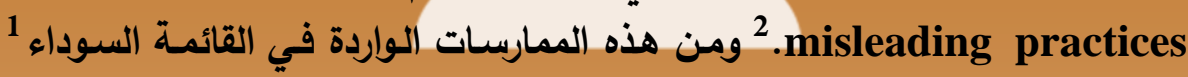

(d) the arrangements for payment, delivery, performance and the complaint handling policy, if they depart from the requirements of professional diligence;

(e) for products and transactions involving a right of withdrawal or cancellation, the existence of such a right."

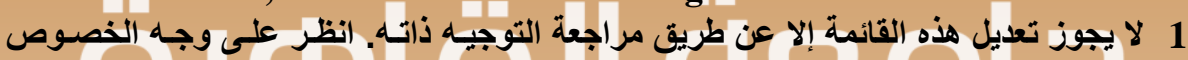
الفقرة السابعة عشرة من ديباجة التوجيه.

2 والممارسات التجارية غير العادلة والواردة في القائمة السوداء المرفقة (ملحق 1) بالتوجيـه

"Misleading commercial practices

1.Claiming to be a signatory to a code of conduct when the trader is not.

2. Displaying a trust mark, quality mark or equivalent without having obtained the necessary authorisation. 
مجلة القانون والاقتصاد - ملحق خاص بمناسبة مرور مائة وخمسين عام

على إنثاء كلية الحقوق - جامعة القاهرة - العدد (الثانى والتسعون)

3. Claiming that a code of conduct has an endorsement from a public or other body which it does not have.

4. Claiming that a trader (including his commercial practices) or a product has been approved, endorsed or authorised by a public or private body when he/it has not or making such a claim without complying with the terms of the approval, endorsement or authorisation.

5. Making an invitation to purchase products at a specified price without disclosing the existence of any reasonable grounds the trader may have for believing that he will not be able to offer for supply or to procure another trader to supply, those products or equivalent products at that price for a period that is, and in quantities that are, reasonable having regard to the product, the scale of advertising of the product and the price offered (bait advertising).

6. Making an invitation to purchase products at a specified price and then: (a) refusing to show the advertised item to consumers; or (b) refusing to take orders for it or deliver it within a reasonable time; or (c) demonstrating a defective sample of it, with the intention of promoting a different product (bait and switch).

7. Falsely stating that a product will only be available for a very limited time, or that it will only be available on particular terms for a very limited time, in order to elicit an immediate decision and deprive consumers of sufficient opportunity or time to make an informed choice.

8. Undertaking to provide after-sales service to consumers with whom the trader has communicated prior to a transaction in a language which is not an official language of the Member State where the trader is located and then making such service available only in another language without clearly disclosing this to the consumer before the consumer is committed to the transaction.

9. Stating or otherwise creating the impression that a product can legally be sold when it cannot.

10. Presenting rights given to consumers in law as a distinctive feature of the trader's offer. 11. Using editorial content in the media to promote a product where a trader has paid for the 
promotion without making that clear in the content or by images or sounds clearly identifiable by the consumer (advertorial). This is without prejudice to Council Directive 89/552/EEC (1). 12. Making a materially inaccurate claim concerning the nature and extent of the risk to the personal security of the consumer or his family if the consumer does not purchase the product. 13. Promoting a product similar to a product made by a particular manufacturer in such a manner as deliberately to mislead the consumer into believing that the product is made by that same manufacturer when it is not.

14. Establishing, operating or promoting a pyramid promotional scheme where a consumer gives consideration for the opportunity to receive compensation that is derived primarily from the introduction of other consumers into the scheme rather than from the sale or consumption of products.

15. Claiming that the trader is about to cease trading or move premises when he is not.

16. Claiming that products are able to facilitate winning in games of chance.

17. Falsely claiming that a product is able to cure illnesses, dysfunction or malformations.

18. Passing on materially inaccurate information on market conditions or on the possibility of finding the product with the intention of inducing the consumer to acquire the product at conditions less favourable than normal market conditions.

19. Claiming in a commercial practice to offer a competition or prize promotion without awarding the prizes described or a reasonable equivalent.

20. Describing a product as 'gratis', 'free', 'without charge' or similar if the consumer has to pay anything other than the unavoidable cost of responding to the commercial practice and collecting or paying for delivery of the item.

21. Including in marketing material an invoice or similar document seeking payment which gives the consumer the impression that he has already ordered the marketed product when he has not. 
مجلة القانون والاقتصاد - ملحق خاص بمناسبة مرور مائة وخمسين عام

على إنشاء كلية الحقوق - جامعة القاهرة - العدد (الثانى والتسعون)

22. Falsely claiming or creating the impression that the trader is not acting for purposes relating to his trade, business, craft or profession, or falsely representing oneself as a consumer.

23. Creating the false impression that after-sales service in relation to a product is available in a Member State other than the one in which the product is sold.

Aggressive commercial practices

24. Creating the impression that the consumer cannot leave the premises until a contract is formed.

25. Conducting personal visits to the consumer's home ignoring the consumer's request to leave or not to return except in circumstances and to the extent justified, under national law, to enforce a contractual obligation.

26. Making persistent and unwanted solicitations by telephone, fax, email or other remote media except in circumstances and to the extent justified under national law to enforce a contractual obligation. This is without prejudice to Article 10 of Directive 97/7/EC and Directives 95/46/EC (1) and 2002/58/EC.

27. Requiring a consumer who wishes to claim on an insurance policy to produce documents which could not reasonably be considered relevant as to whether the claim was valid, or failing systematically to respond to pertinent correspondence, in order to dissuade a consumer from exercising his contractual rights.

28. Including in an advertisement a direct exhortation to children to buy advertised products or persuade their parents or other adults to buy advertised products for them. This provision is without prejudice to Article 16 of Directive 89/552/EEC on television broadcasting.

29. Demanding immediate or deferred payment for or the return or safekeeping of products supplied by the trader, but not solicited by the consumer except where the product is a substitute supplied in conformity with Article 7(3) of Directive 97/7/EC (inertia selling).

30. Explicitly informing a consumer that if he does not buy the product or service, the trader's job or livelihood will be in jeopardy. 
الالِّعـاء -على خـلاف الحقيقـة- مـن قِبَل التـاجر بأنـه من المـوقعين على مدونـة

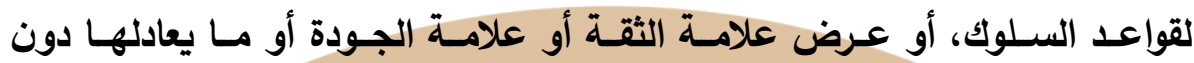

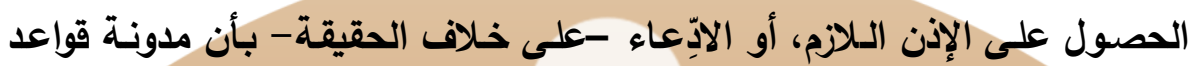

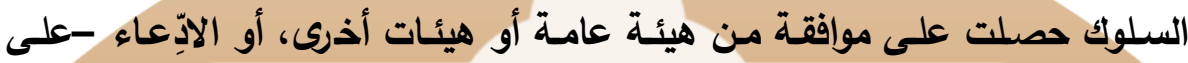

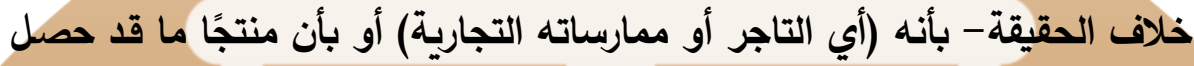
على موافقة أو اعتماد أو إذن من قبل هلئ هيئة عامة أو خاصة. وينهي البنـا الخـامس من القائمسة عبارات الإغراء وإعلانـات المبالغة، مثل عبارات "قميص بعشرة جنيهات" عندما يكون التاجر، في خله اله الحملة الإعلانية،

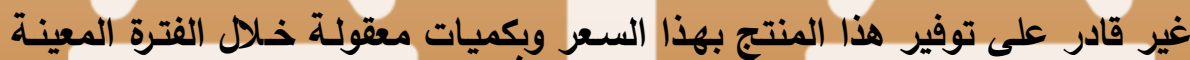

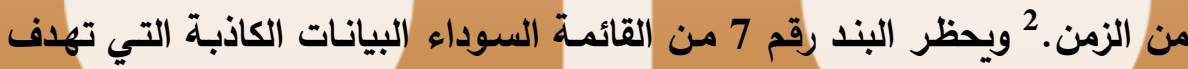

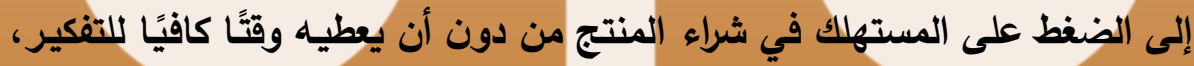

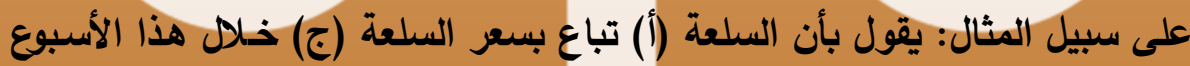

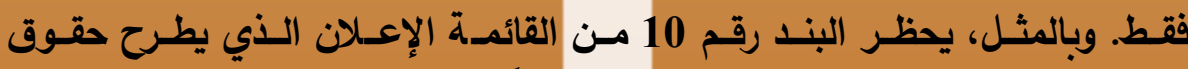

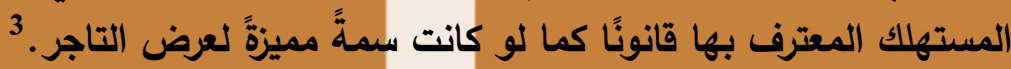

وينهي البند 15 الإعلانات الكاذبة التي يقوم بها بعض التجار معانين أنهم

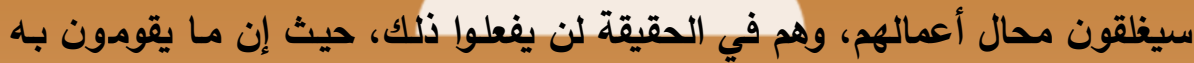

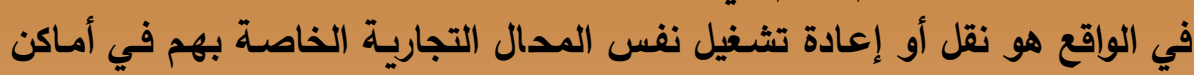

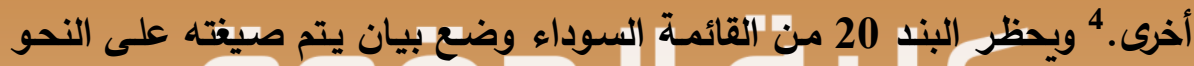

31. Creating the false impression that the consumer has already won, will win, or will on doing a particular act win, a prize or other equivalent benefit, when in fact either: - there is no prize or other equivalent benefit, or - taking any action in relation to claiming the prize or other equivalent benefit is subject to the consumer paying money or incurring a cost." 1 البنود من 1-1 من القائمة.

Poncibo and Incardona, op. cit., p. 322. 2 3 انظر أيضًا المرجع السابق.

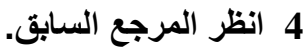


مجلة القانون والاقتصاد - ملحق خاص بمناسبة مرور مائة وخمسين عام

على إنشاء كلية الحقوق - جامعة القاهرة - العدد (الثانى والتسعون)

التالي: "خذ المنتج مجانًا" إذا كـان المستهلك سيدفع تكـاليف التسليم أو تكـاليف

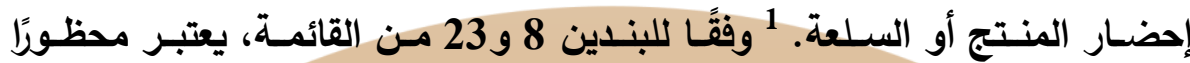

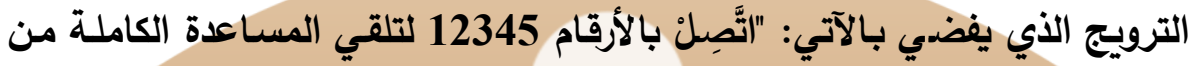

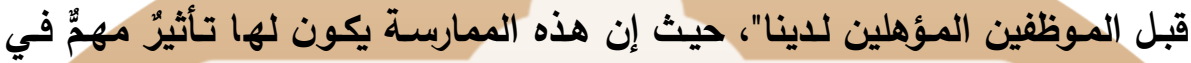

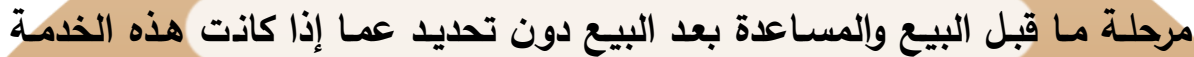
سوف تكون في الواقع بلغة أخرى أو في بلد آخر.

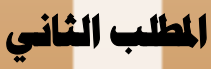

\section{المعارسات التجارية العدوانية}

\section{Aggressive Commercial Practices}

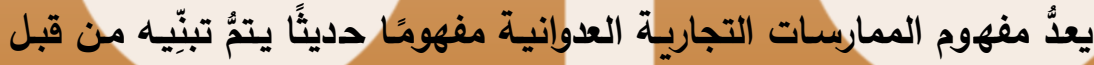

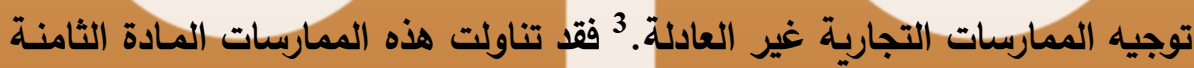

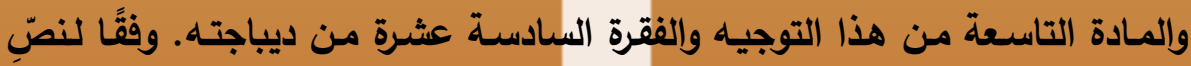

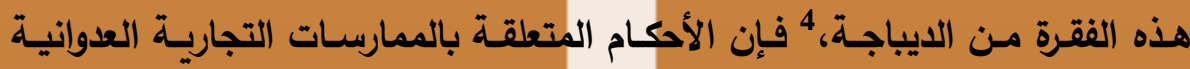

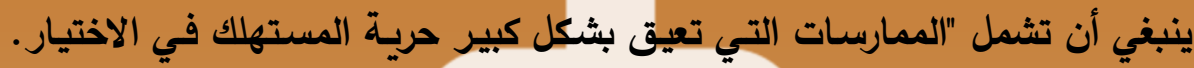

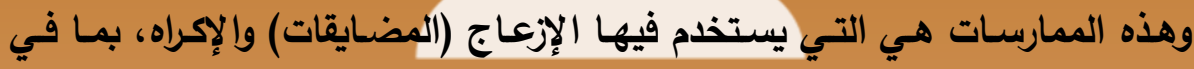

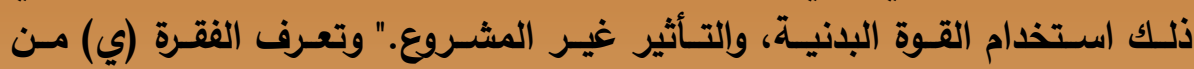

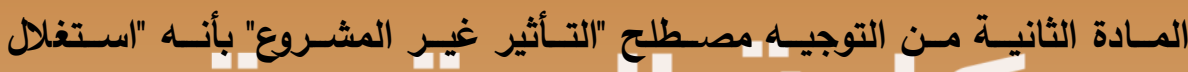

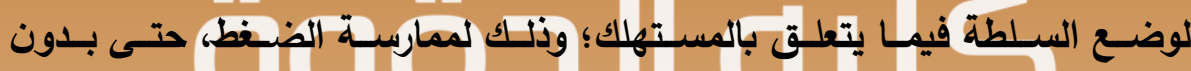

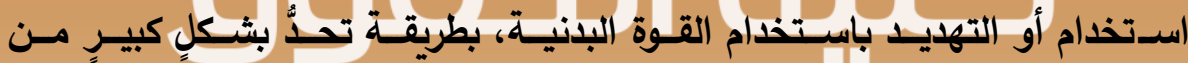

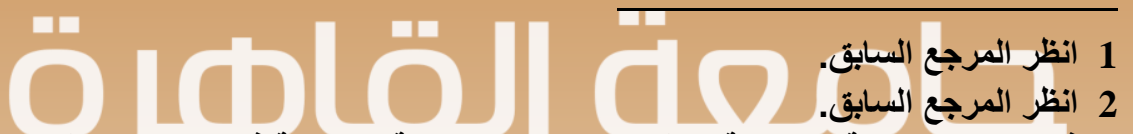

3 فيما يتعلق بالخلفية التاريخية لحظر الممارسات التجارية العدوانية في التوجيه، انظر:

Leistner, op. cit., pp. 163-166.

4 ويجري نص الفقرة السادسة عشرة من الديباجة ـ باللغة الإنليزية ـ على النحو التالي:

"The provisions on aggressive commercial practices should cover those practices which significantly impair the consumer's freedom of choice. Those are practices using harassment, coercion, including the use of physical force, and undue influence." 


\section{قدرة المستهلك على اتِّخاذ قرار مستنير". 1}

وتعتبر ممارسة ما كونها "عدوانية"، عندما - ناظرًا إلى إطارها الفعلي وأخذًا

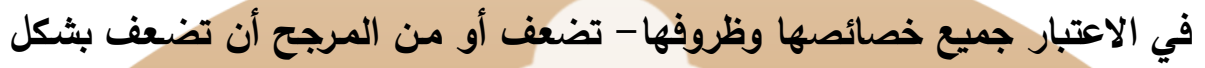

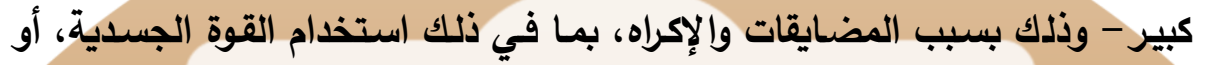

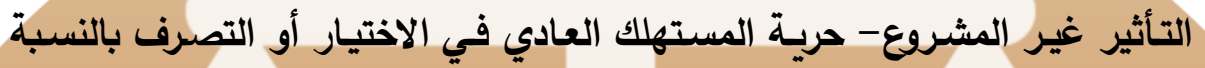

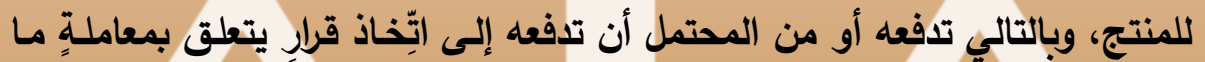

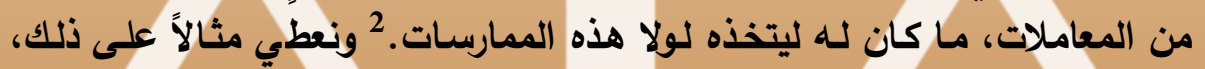

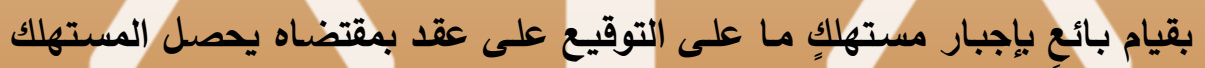

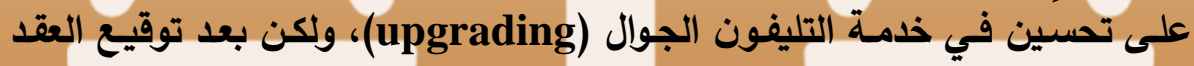

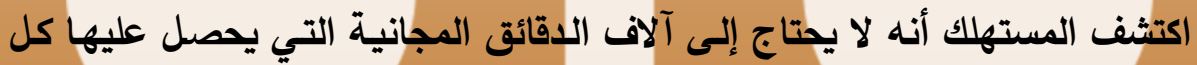

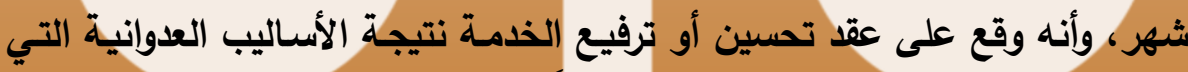

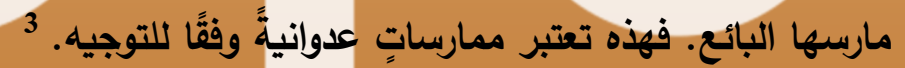

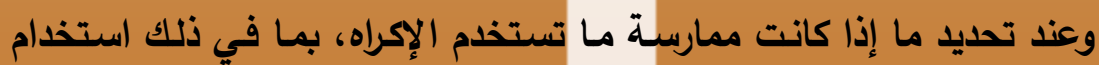

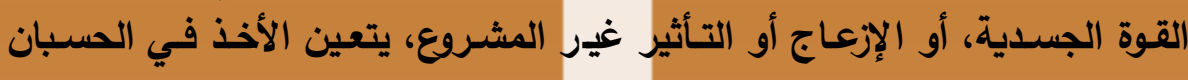

1 والتالي هو نص هذه الفقرة باللغة الإنجليزية:

" (J) 'undue influence' means exploiting a position of power in relation to the consumer so as to apply pressure, even without using or threatening to use physical force, in a way which significantly limits the consumer's ability to make an informed decision;

2 انظر المادة الثامنة من التوجيه. ويجري نصها باللغة الإنجليزية على النحو التالي:

"A commercial practice shall be regarded as aggressive if, in its factual context, taking account of all its features and circumstances, by harassment, coercion, including the use of physical force, or undue influence, it significantly impairs or is likely to significantly impair the average consumer's freedom of choice or conduct with regard to the product and thereby causes him or is likely to cause him to take a transactional decision that he would not have taken otherwise."

Reilly, op. cit., p. 116. 
مجلة القانون والاقتصاد - ملحق خاص بمناسبة مرور مائة وخمسين عام

على إنثاء كلية الحقوق - جامعة القاهرة - العدد (الثانى والتسعون)

العوامل التالية التي تضمنتها المادة التاسعة من التوجيه:1

(أ) توقيت وموقع وطبيعة واستمرارية الممارسة التجاربة.

(ب) استخدام اللغة أو السلوك التهايدي أو المسيء.

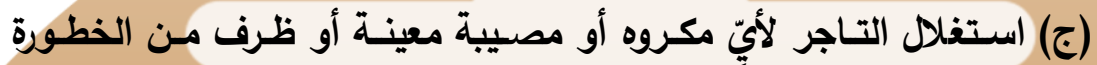

بحيث تقيد أو تضعف قدرة المستهلك على الحكم، مـع علم التاجر بذآلك، للتأثير على قرار المستهلك فيما يتعلق المنتج.

(د) أية عوائق غير تعاقدية تتصف بأنها مرهقة أو غير متناسبة مفروضـة

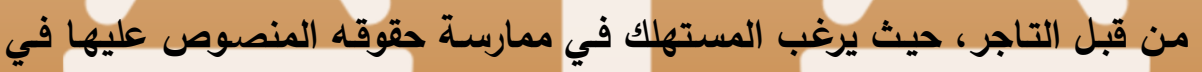
العقد، بما في ذلك الحق في إنهاء العقد أو التحول إلى منتج آخر أو تاجر آخر.

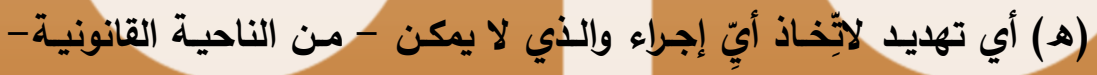

إن الهذف الأساسي لحظر مثل هذه الممارسـات هو حمايـة المستهلك منها،

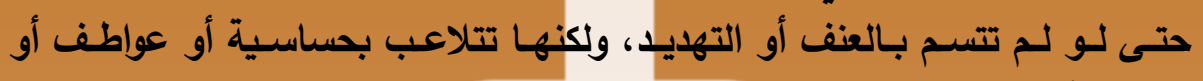

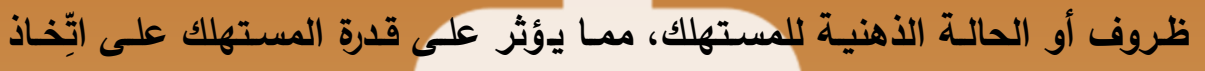

1 ويجري نصها باللغة الإنجليزية على النحو التالي:

"In determining whether a commercial practice uses harassment, coercion, including the use of physical force, or undue influence, account shall be taken of:

(a) its timing, location, nature or persistence;

(b) the use of threatening or abusive language or behaviour;

(c) the exploitation by the trader of any specific misfortune or circumstance of such gravity as to impair the consumer's judgement, of which the trader is aware, to influence the consumer's decision with regard to the product;

(d) any onerous or disproportionate non-contractual barriers imposed by the trader where a consumer wishes to exercise rights under the contract, including rights to terminate a contract or to switch to another product or another trader;

(e) any threat to take any action that cannot legally be taken." 


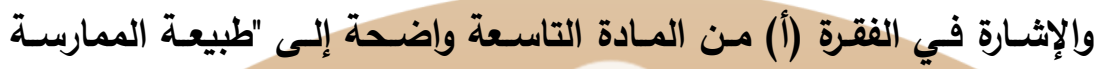

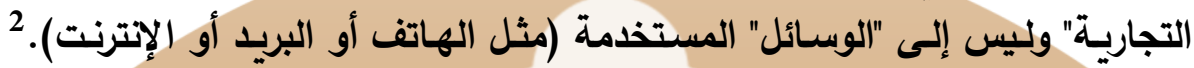

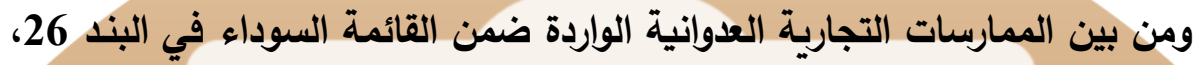

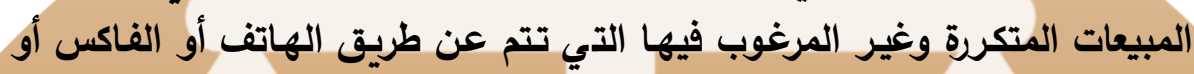

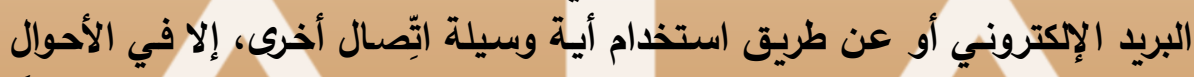

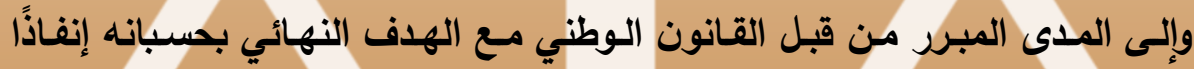

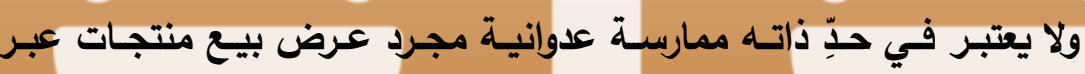

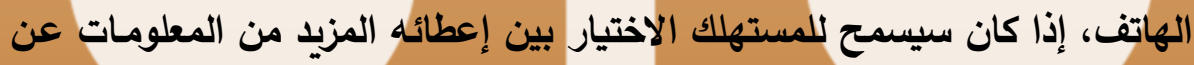

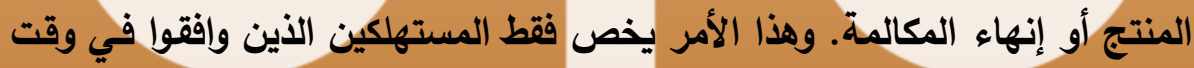

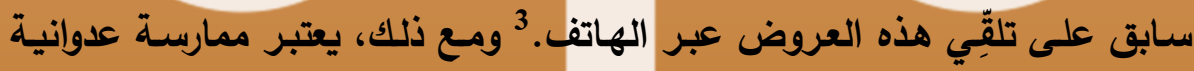

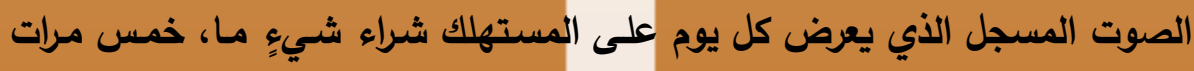

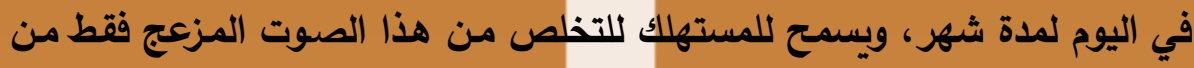

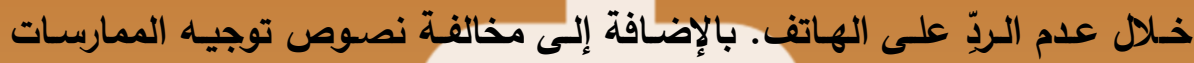

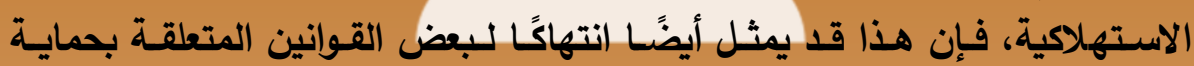

الخصوصية.

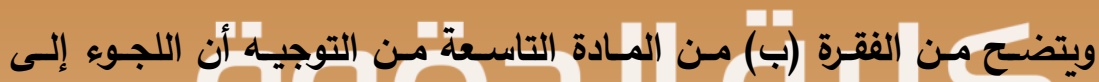

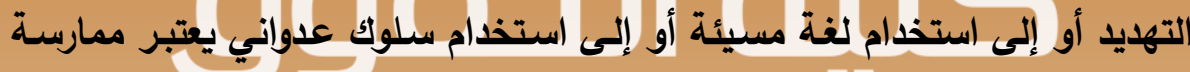

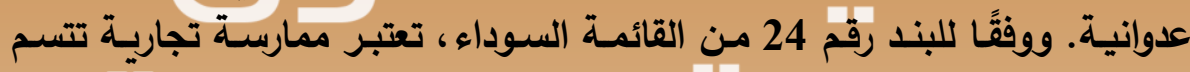

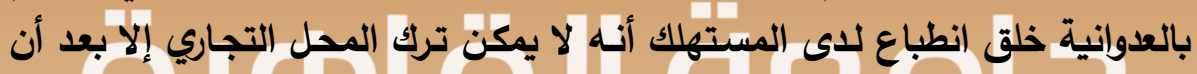

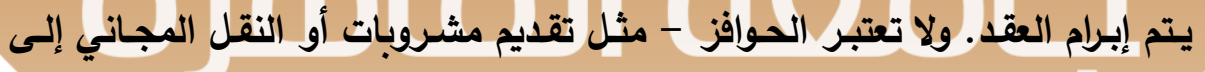

Poncibo and Incardona, op. cit., p. 323. 1

2 3 انظر المرجع السابق.

4 انظر المرجع السابق. 
مجلة القانون والاقتصاد - ملحق خاص بمناسبة مرور مائة وخمسين عام

على إنشاء كلية الحقوق - جامعة القاهرة - العدد (الثانى والتسعون)

المحال التجارية للتاجر، مع ذلك - ضمن الممارسات التجارية غير العادلة. 1

وتجدر الإثـارة إلى البند رقم 30 مـن القائمـة السوداء التي تعتبر ممارسدة

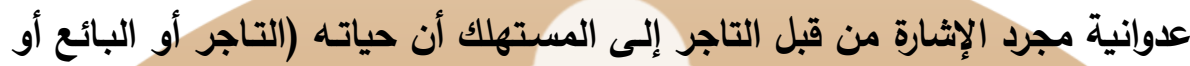

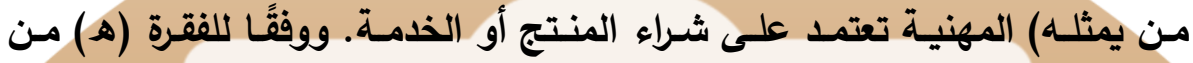

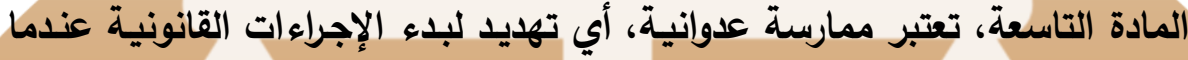

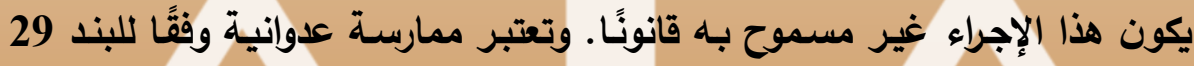

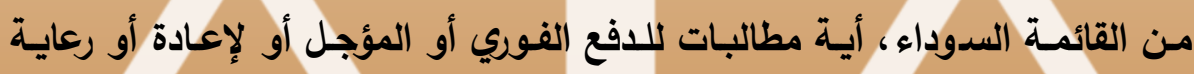
المنتجات التي يوردها التاجر دون طلب من قبل المستهلك.

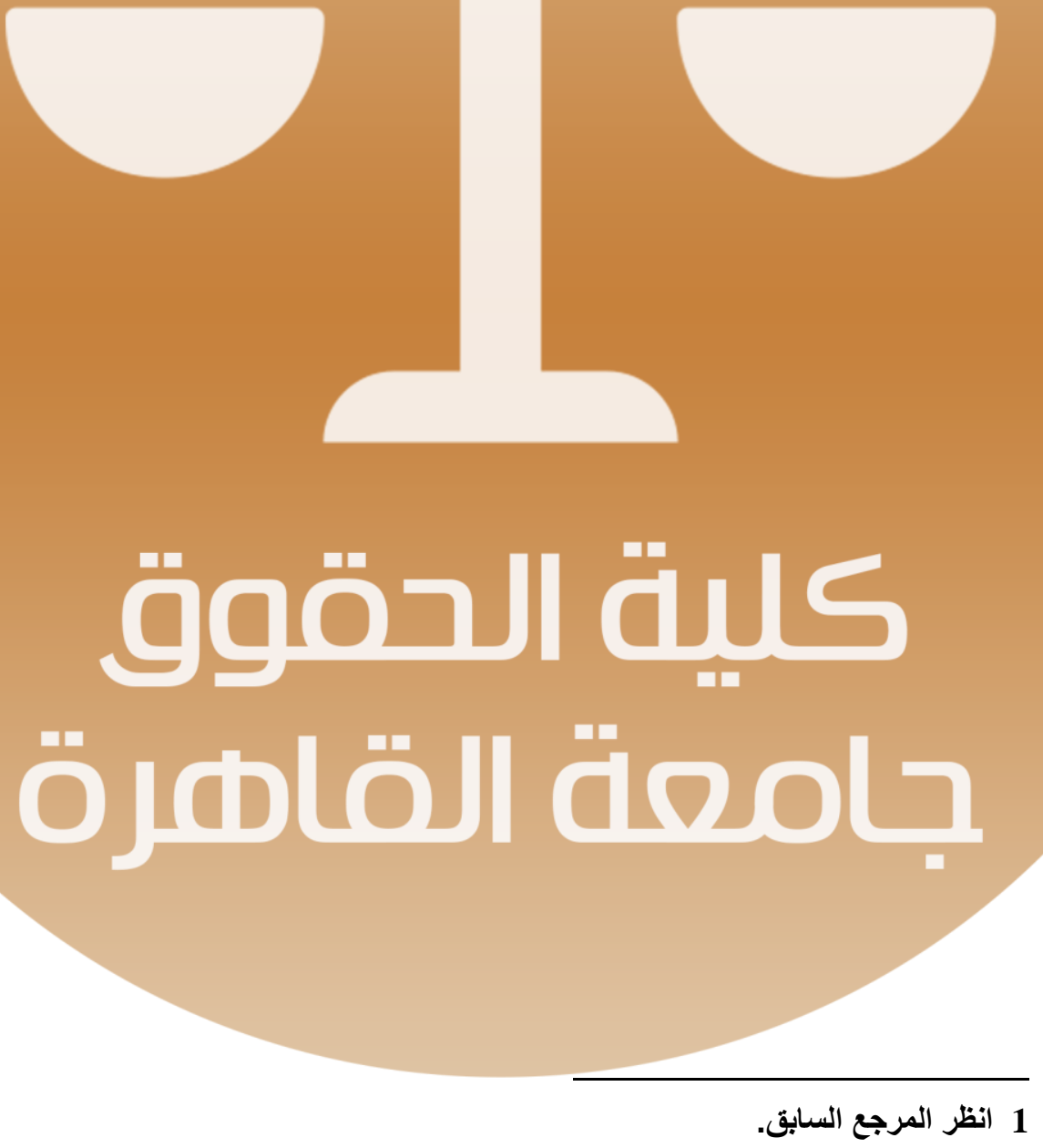




\section{|الفصل الثاني \\ نطاق الممارسات التجارية فير العادلة \\ من هيث الأشخاص والتطورات المديثة}

لا يحمي توجيه الممارسـات التجاريـة غير العادلة أي مستهلك، حيث يوفر

الحماية للمستهاك الذي تتوافر فيه بعض الصفات والخصائص. فعلى سبيل المثال

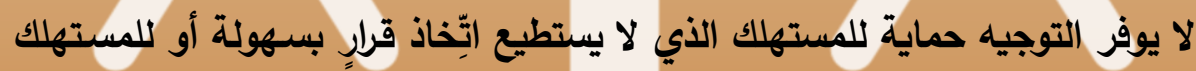

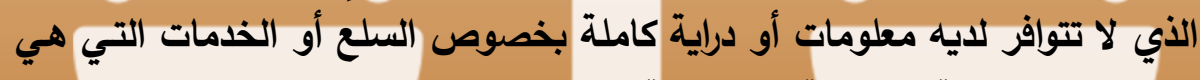

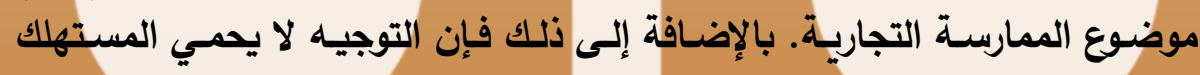

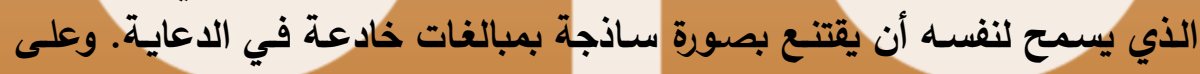
الجانب الآخر، يحمي التوجيه فقط "المستهلك العادي average consumer".

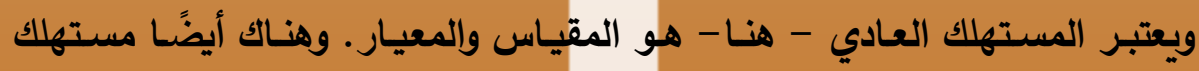

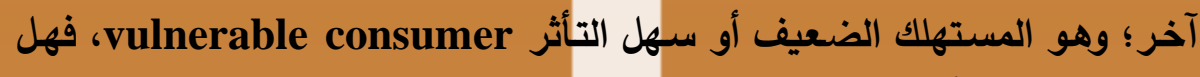

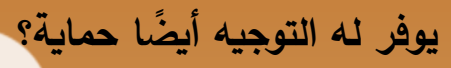

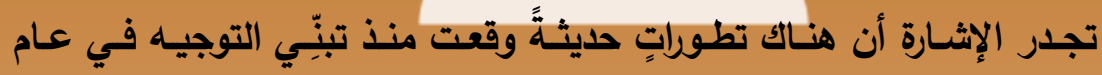

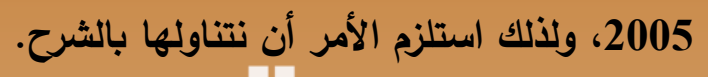
وبناءً على هذا نقسم هذا الفصل إلى المبحثين التاليين: المبحث الأول: المسـتفيدون مـن حظر الممارسـات التجارِــة غيـر العادلـة المبحث الثاني: التطورات الحديثة منذ تبنّي التوجيه في عام 2005 وإلى (المستهالك العادي). (الإن الآن. 
مجلة القانون والاقتصاد - ملحق خاص بمناسبة مرور مائة وخمسين عام

على إنثاء كلية الحقوق - جامعة القاهرة - العدد (الثانى والتسعون)

\section{المبمث الأول}

المستفيدون من مثر المالمارسات التجارية فيز العادلة

|الستمداك العادي

\section{The Average Consumer}

لا يحمـي التوجيـه أيَّ مسـتهلك، ولكنـه يحمـي فقـط المسـتهلك العـادي

average consumer

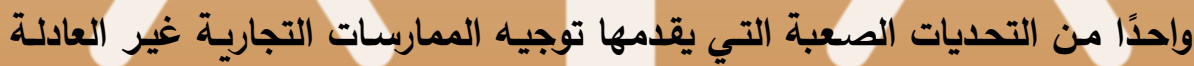

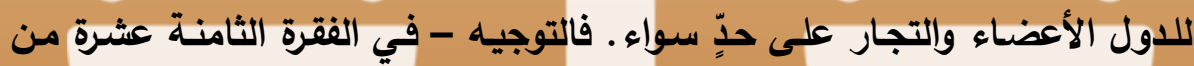

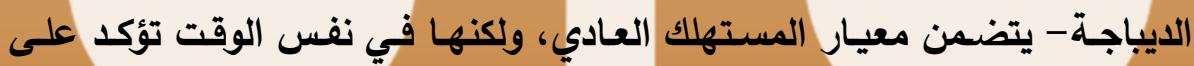

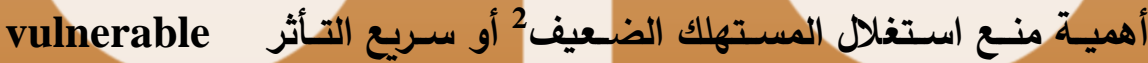
consumer

$$
1 \text { للمزيد من التفصيل في تصديد مفهوم المستهلك العادي، انظر: }
$$

Rossella Incardona and Cristina Poncibo, 'The Average Consumer, the Unfair Commercial Practices Directive, and the Cognitive Revolution' (2007) 30 (1) Journal of Consumer Policy, pp. 21-38; and Vanessa Mak, 'Standards of Protection: In Search of the 'Average Consumer' of EU Law in the Proposal for a Consumer Rights Directive.' A working paper available at: http://papers.ssrn.com/sol3/papers.cfm?abstract_id=1626115. تم الاطِّلاع على الموقع بتَاريخ 31 مايو 2016. 2 و للمزيد عن فكرة المستهلك العادي وفكرة المستهلك الضعيف وفكرة المجموعة المستهدفة،

Duivenvoorde, op. cit., pp.20-26.

Avishalom Tor, op. cit., pp. 16-18; and Anna Ciancio, op. cit., p. 9 et. seq.

$$
3 \text { ويجري نصها باللغة الإنجليزية على النحو التالي: }
$$

"It is appropriate to protect all consumers from unfair commercial practices; however the Court of Justice has found it necessary in adjudicating on advertising cases since the enactment of Directive 
الأوروبية - هو "الثخص المستنير الذي لايه قدر معقول من اليقظة والحرص، مع الأخذ في الاعتبار العوامل الاجتماعية والثقافية واللغوية.

" an average consumer who is reasonably well-informed and reasonably observant and circumspect, taking into account social, cultural and linguistic factors...."1

ونعرض الآن دور محكمة العدل الأوروبية الرئيس في خلق وتطور مفهوم

"المستهلك العادي"، وذلك من خـلال تصديها لقضايا حرية التجارة باعتباره معيارًا

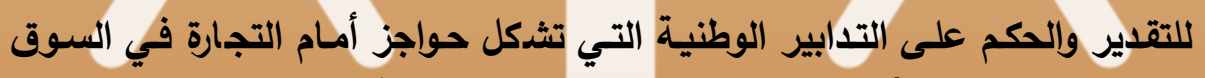

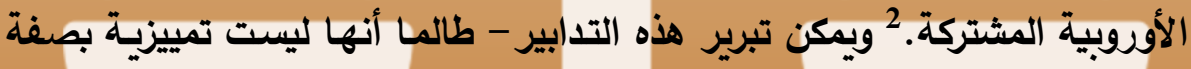

84/450/EEC to examine the effect on a notional, typical consumer. In line with the principle of proportionality, and to permit the effective application of the protections contained in it, this Directive takes as a benchmark the average consumer, who is reasonably well informed and reasonably observant and circumspect, taking into account social, cultural and linguistic factors, as interpreted by the Court of Justice, but also contains provisions aimed at preventing the exploitation of consumers whose characteristics make them particularly vulnerable to unfair commercial practices. Where a commercial practice is specifically aimed at a particular group of consumers, such as children, it is desirable that the impact of the commercial practice be assessed from the perspective of the average member of that group. It is therefore appropriate

to include in the list of practices which are in all circumstances unfair a provision which, without imposing an outright ban on advertising directed at children, protects them from direct exhortations to purchase. The average consumer test is not a statistical test. National courts and authorities will have to exercise their own faculty of judgement, having regard to the case-law of the Court of Justice, to determine the typical reaction of the average consumer in a given case." 
مجلة القانون والاقتصاد - ملحق خاص بمناسبة مرور مائة وخمسين عام

على إنشاء كلية الحقوق - جامعة القاهرة - العدد (الثانى والتسعون)

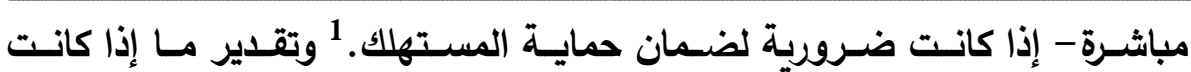
ضرورية لضمان حماية المستهلك يكون من خـلا النظر إلى مفهوم "المستهلك فيكانه

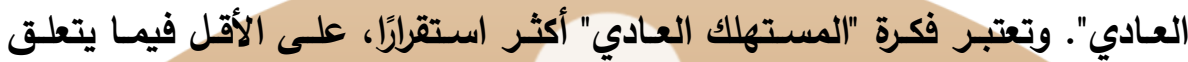

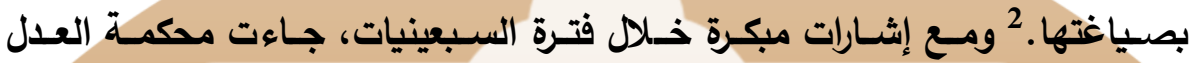

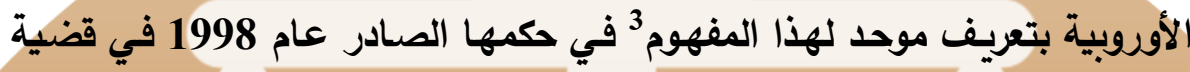

${ }^{4}$.Gut Springenheide

وعرفت المحكمة المستهلك العادي في هذه القضية بأنـه "الثـضص المستتير

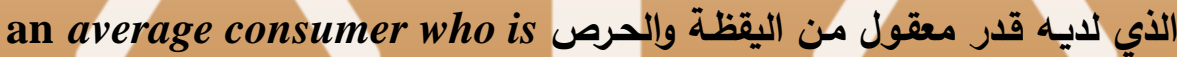
reasonably well-informed and reasonably observant and

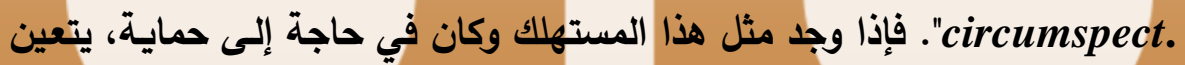

Vanessa Mak, 'Standards of Protection: In Search of the "Average Consumer" of EU Law in the Proposal for a Consumer Rights Directive.' A working paper, June 2010, p. 4. Available at: http://papers.ssrn.com/sol3/papers.efm?abstract_id=1626115

تم الاطِّلاع على الموقع بتاريخ 31 مايو 2016. 1 2

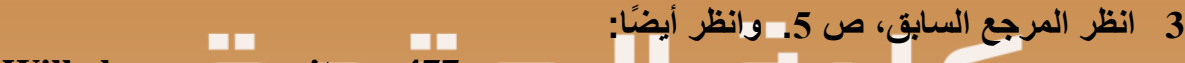
Wilhelmsson, op. cit., p. 477 . 4 Judgment of the European Court of Justice in Case C-210/96 Gut Springenheide GmbH and Others v Oberkreisdirektor des Kreises Steinfurt Ä Amt für Lebensmittelüberwachung, July 16, 1998. Available at: content/EN/TXT/?uri=CELEX\%3A61996CJ0210 تم الاطّّلاع على الموقع بتاريخ 31 مايو 2016. وللمزيد عن هذه القضية وأهميتها في تحديد

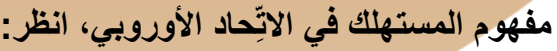

Incardona and Poncibo, op. cit., p. 22 et seq. 5 5

Vanessa Mak, op. cit., p.4. 
Wilhelmsson, op. cit., p. 478.

$$
1 \text { ويثوافر ملخص هذه القضية على الموقع التالي على شبكة الإنترنت }
$$

http://curia.europa.eu/en/actu/communiques/cp98/cp9848en.htm تم الاطِّلاع على الموقع بتاريخ 31 مايو 2016. والملخص باللغة الإنجليزية على النحو التالي: "Gut Springenheide markets eggs ready-packed under the description "6-Korn - 10 frische Eier" (six-grain - 10 fresh eggs). According to the company, the six varieties of cereals in question account for $60 \%$ of the feed mix used to feed the hens producing the eggs it markets. A slip of paper enclosed in each pack of eggs extols the beneficial effect which this feed has on the quality of the eggs. Having repeatedly informed Gut Springenheide that it had reservations with regard to the description and the pack insert, on 24 July 1989, the Oberkreisdirektor des Kreises Steinfurt - Amt für Lebensmittelüberwachung (Chief Administrative Officer of the Rural District of Steinfurt - Office for Supervision of Foodstuffs) directed the company to remove them. In addition, a fine was imposed on its director on 5 September 1990.

By judgment of 11 November 1992, the Verwaltungsgericht (Administrative Court), Münster, dismissed the declaratory action brought by Gut Springenheide and its director on the ground that the description and the pack insert infringed Paragraph 17(1) of the Lebensmittel- und Bedarfsgegenständegesetz (Foodstuffs and Consumer Goods Law) under which misleading descriptions are prohibited.

Gut Springenheide and its director appealed unsuccessfully against that judgment. The German appeal court considered that the description and the pack insert in question infringed Community legislation on the common organization of the market in eggs. That legislation includes a 1990 regulation on marketing standards for eggs which allows egg packaging to carry descriptions or statements designed to promote sales provided that they are not liable to mislead the purchaser. According to the German appeal court, the description "six-grain - 10 fresh eggs", which is also a trade mark, and the pack insert are liable to mislead a significant proportion of consumers in 
مجلة القانون والاقتصاد - ملحق خاص بمناسبة مرور مائة وخمسين عام

على إنشاء كلية الحقوق - جامعة القاهرة - العدد (الثانى والتسعون)

كانت تقوم Springenheide بتسـويق بيض معبأ وجاهز تحت وصف "

6- حبوب -10 بيض طازج '6-grain-10 fresh eggs' " كإشـارة إلى مزئج

that they imply falsely that the feed given to the hens is made up exclusively of the six cereals indicated and that their eggs have particular qualities.

Gut Springenheide and its director then brought an appeal on a point of law before the Bundesverwaltungsgericht (Federal Administrative Court) which took the view that the Community legislation on the promotion of sales could be interpreted in two ways. Either the misleading nature of the descriptions in question is to be assessed with reference to the actual expectations of consumers, in which case those expectations ought, if necessary, to be ascertained by means of a survey of a representative sample of consumers or on the basis of an expert's report, or the provision in question is based on an objective notion of a purchaser, which is open to legal interpretation only, irrespective of the actual expectations of consumers. In other words, which is the reference consumer to be used as a standard for determining whether a statement designed to promote sales of eggs is likely to mislead the purchaser, in breach of the 1990 regulation? That is the background against which the Bundesverwaltungsgericht ordered that proceedings be stayed and the questions, on which the Court ruled today, be referred to the Court of Justice.

Referring to the Community legislation and case-law on the protection of consumers from misleading information, the Court has held that, in order to determine whether a statement or description designed to promote sales of eggs is liable to mislead the purchaser, in breach of Article 10(2)(e) of Regulation No 1907/90, the national court must take into account the presumed expectations which it evokes in an average consumer who is reasonably well-informed and reasonably observant and circumspect. However, Community law does not preclude the possibility that, where the national court has particular difficulty in assessing the misleading nature of the statement or description in question, it may have recourse, under the conditions laid down by its own national law, to a consumer research poll or an expert's report as guidance for its judgment." 
الأعلاف المستخدم في تغذية الاجاج المحتوية على 60٪ من مجموعة متكونـة من

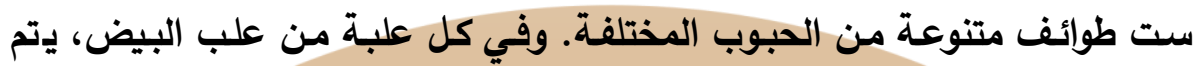

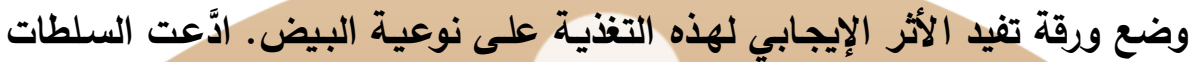

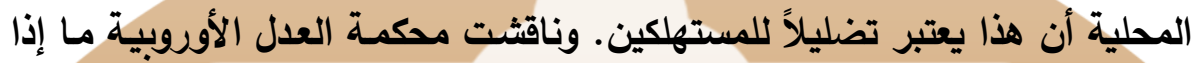

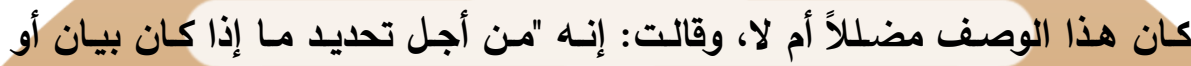

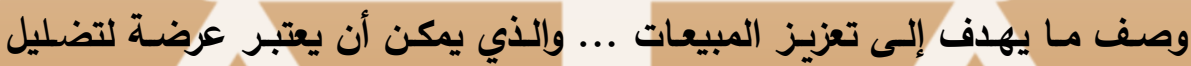

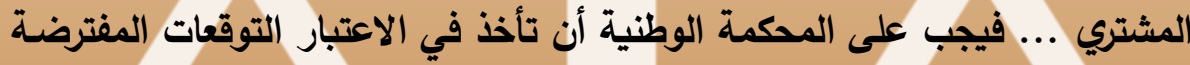
التي تستدعي المستهلك العادي، وهو "الثخص المستنيز الذي لايهـ قدر معقول من اليقظة والحرصي".

ويوضح حكم محكمة العدل الأوروبية أيضًا أن قانون الجماعة الأوروبية لا

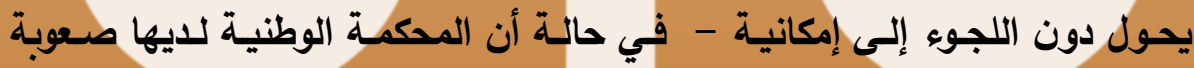

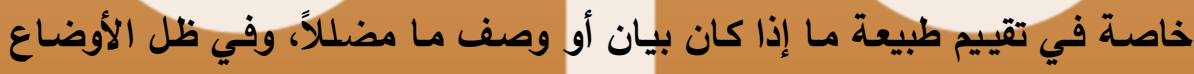

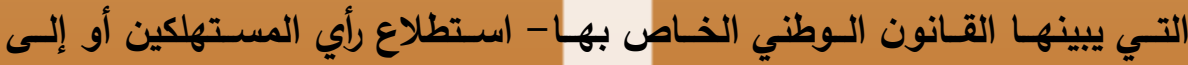

$$
\text { الحصول على تقرير خبير . }
$$

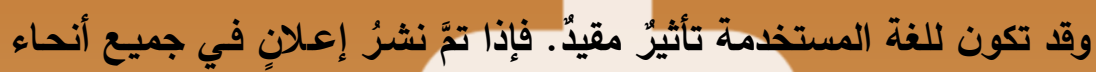

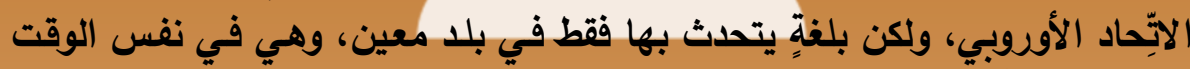

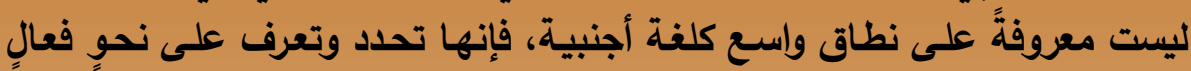

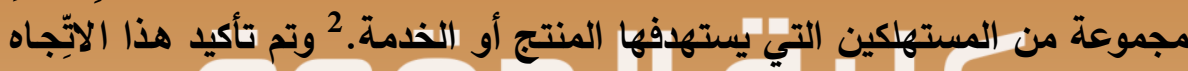

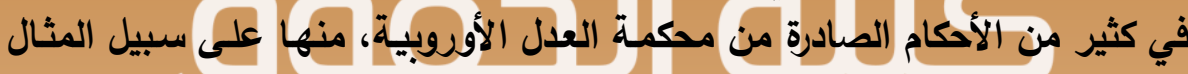
قضية:

CeWe Color AG\&Co OHG v Office for Harmonization in the Internal Market ${ }^{3}$

Incardona and Poncibo, op. cit., p. 22.

1

2 
مجلة القانون والاقتصاد - ملحق خاص بمناسبة مرور مائة وخمسين عام

على إنثاء كلية الحقوق - جامعة القاهرة - العدد (الثانى والتسعون)

بقولها:

"28- In this case, as stated correctly by the Board of Appeal (the DigiFilm decision, paragraph 27; the DigiFilmMaker decision, paragraph 28) the goods and services at issue are directed not only at a specialist public but also more widely at the public at large. In addition, the marks sought are made up of elements of the English language. As a consequence, the relevant public is the average English-speaking consumer, normally well informed and reasonably attentive."

وفي حالـة مـا إذا كان المنتج أو الخدمة مخصصةًة أو معلنًا عنها في إقليم

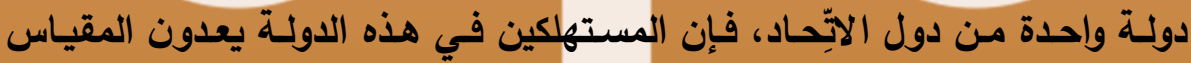

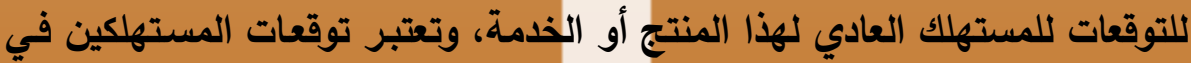

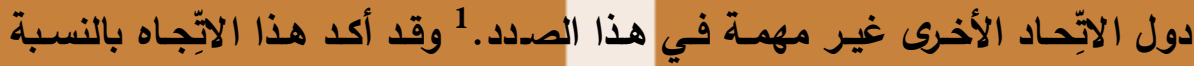

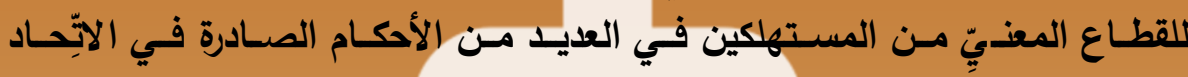

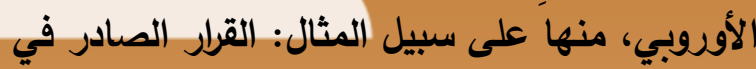

El Corte Ingles, SA v Office for Harmonization in the Internal Market $^{2}$

The Court of First Instance (Fifth Chamber), in Joined Cases T178/03 and T-179/03, 8 September 2005.

$$
\text { هذا القرار متاح على الموقع التالي: }
$$

http://eur-lex.europa.eu/legalcontent/EN/TXT/PDF/?uri=CELEX:62003TJ0178\&from=EN

$$
1 \text { نظم الإِّلاعًاع على الموقع في } 31 \text { مايو } 2016 .
$$

Incardona and Poncibo, op. cit., p. 22. 
674-Given the nature of the goods and services in issue, which are items of everyday consumption, and the fact that the earlier word marks are registered and protected in Spain, the target public in respect of which the assessment of likelihood of confusion must be carried out is made up of average consumers in that Member State, who are, for the most part, Spanish-speaking."

وتقوم محكمـة العدل الأوروبية - بمجرد تحديـ المجموعـة المستهدفة مـن

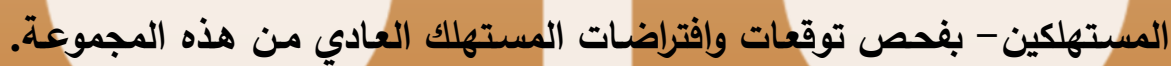

$$
\text { وقد أكدت مسلكها هذا في قضينة: }
$$

Henkel KGaA v. Office for Harmonization in the Internal Market ${ }^{1}$

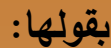

"633-It must be pointed out that the products covered by

The Court of First Instance (Fourth Chamber). In Joined Cases T183/02 and T-184/02, 17 March, 2004.

$$
\text { هذا القرار متاح على الموقع التالي: }
$$

http://curia.europa.eu/juris/showPdf.jsf?text=\&docid=48996\&pageIndex= $\underline{0} \&$ doclang $=$ en $\&$ mode $=1$ st \& dir $=\&$ occ $=$ first $\&$ part $=1 \&$ cid $=307828$

تم الإِّلاع على هذا الموقع بتاريخ 31 مايو 2016. انظر:

The Court of First Instance (Fourth Chamber). In Case T-393/02, 24 November, 2004.

$$
\text { هذا القرار متاح على الموقع التالي: }
$$

http://curia.europa.eu/juris/showPdf.jsf?text=\&docid=49703\&pageIndex= $\underline{0 \& \text { doclang }=\text { en } \& \text { mode }=1 \text { st } \& \text { dir }=\& o c c=\text { first } \& \text { part }=1 \& \text { cid }=316724}$ 
مجلة القانون والاقتصاد - ملحق خاص بمناسبة مرور مائة وخمسين عام

على إنشاء كلية الحقوق - جامعة القاهرة - العدد (الثانى والتسعون)

the mark applied for are everyday consumables, directed at consumers as a whole. The distinctiveness of the mark for which registration is sought must accordingly be assessed having regard to the presumed expectation of an average consumer who is reasonably well informed and reasonably observant and circumspect"

وقد يختلف مستوى الانتبـاه المطلـوب مـن "المسـتهلك العـادي" حسـب فئة

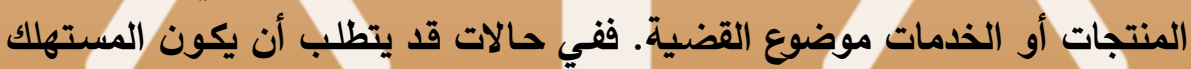

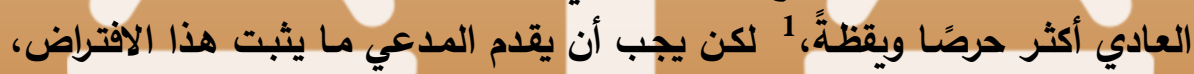

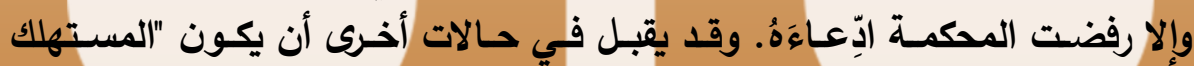

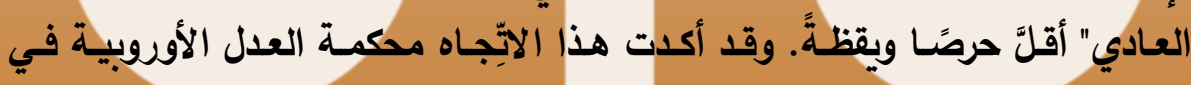
حكمها في قضية:

New Look Ltd $v$. Office for harmonization in the

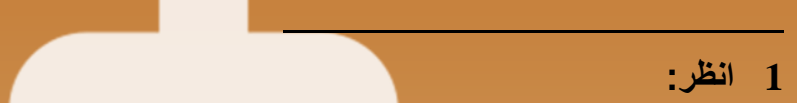

August Storck KG v. Office for Harmonization in the Internal Market . Case C-24/05 P. Judgment of the Court (First Chamber), 22 June 2006.

http://curia.europa.eu/juris/showPdf.jsf;jssessionid=9ea7d2dc30dbac62560 1c72d49df8fdef9819501865e.e34KaxiLc3qMb40Rch0SaxuKaN50?docid $=65020 \&$ pageIndex $=0 \&$ doclang $=$ EN\&mode $=1$ st $\&$ dir $=\& o c c=$ first $\&$ part $=1$ \&cid $=44314$ تم الاطِّلاع على الموقع بتاريخ التبا 31 مايو 2016. وفي هذه القضية تطلبت المحكمة أن يباشر

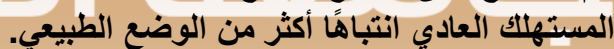

"None the less, it is when making his choice between different products in the category concerned that the average consumer exhibits the highest level of attention so that the question whether or not the average consumer sees the mark at the time of purchase is of particular importance for determining whether the mark has acquired distinctive character through use" 
internal Market. ${ }^{1}$

$$
\text { بقولها: }
$$

"43-It should be noted in this regard that the average consumer's level of attention may vary according to the category of goods or services in question (see, by analogy, Case C-342/97 Lloyd Schuhfabrik Meyer [1999] ECR I-3819, paragraph 26). As OHIM rightly pointed out, an applicant cannot simply assert that in a particular sector the consumer is particularly attentive to trade marks without supporting that claim with facts or evidence. As regards the clothing sector, the Court finds that it comprises goods which vary widely in quality and price. Whilst it is possible that the consumer is more attentive to the choice of mark where he or she buys a particularly expensive item of clothing, such an approach on the part of the consumer cannot be presumed without evidence with regard to all goods in that sector. It follows that that argument must be rejected."

وفي العديد من القضايا التي اشتملت على وضع ملصقات على البضائع،

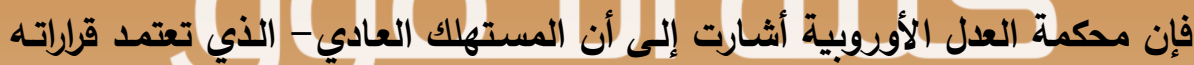
الشرائية على مكونات المنتجات- هو الأي سوف يقوم بقراءة قائمـة المكونـات أولاً.
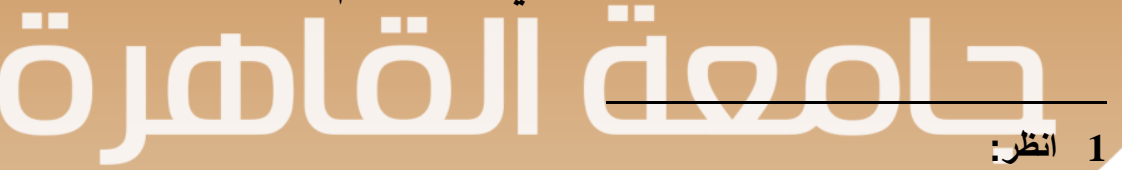

The Court of First Instance (Second Chamber). In Joined Cases T117/03 to T-119/03 and T-171/03, 6 October 2004. هذا القرار متاح على الموقع التالي: http://curia.europa.eu/juris/showPdf.jsf?text=\&docid=84821\&pageIndex= $\underline{0 \text { \&doclang }=\text { en } \& \text { mode }=1 \text { st } \& \text { dir }=\& \text { occ }=\text { first } \& \text { part }=1 \& \text { cid }=325177}$ 
مجلة القانون والاقتصاد - ملحق خاص بمناسبة مرور مائة وخمسين عام

على إنشاء كلية الحقوق - جامعة القاهرة - العدد (الثانى والتسعون)

فقد أثـارت هذه المحكمة في إحدى القضـايا1 التي عرضت عليها أن المستهلك

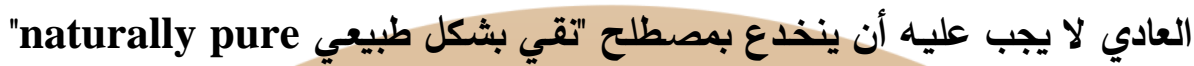

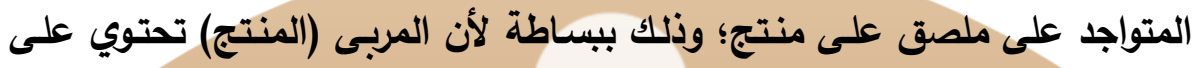

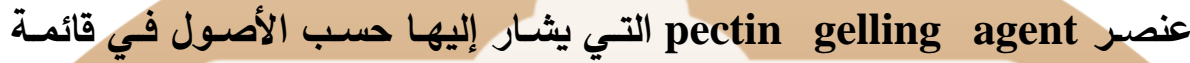
المكونات الموجودة على المنتج.

"22- As regards, first, pectin, it need merely be pointed out that its presence in d'arbo jam is indicated on the label on the packaging in accordance with Article 3(1), point (2), and Article 6(4)(a) and Article 6(5)(a) of the Directive. As the Court has already acknowledged (Case C-51/94 Commission v Germany [1995] ECR 1-3599, paragraph 34), consumers whose purchasing decisions depend on the composition of the products in question will first read the list of ingredients, the display of which is required by Article 6 of the Directive. In those circumstances, an average consumer who is reasonably well informed and reasonably observant and circumspect could not be misled by the term 'naturally pure' used on the label simply because the jam contains pectin gelling agent whose presence is duly indicated on the list of its ingredients (see, to the same effect, Case C-383/97 Van der Laan [1999]

\section{무}

Verein gegen Unwesen in Handel und Gewerbe Köln ev. Adolf Darbo. The Judgement of the Court (First Chamber). In Case C-465/98, 4 April 2000.

http://eur-lex.europa.eu/legal-

$$
\text { هذا القرار متاح على الموقع التالي: }
$$

content/EN/TXT/PDF/?uri=CELEX:61998CJ0465\&from=EN

$$
\text { تم الاطِّلاع على الموقع بتاريخ } 31 \text { مايو } 2016 .
$$


ECR I-731, paragraph 37)."

وفي قضية أخرى، أبدى المحامي العام رأيه فيمـا يتعلق بالتوقعات المفترضـة

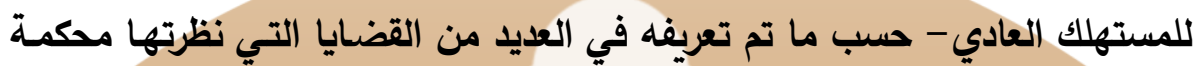

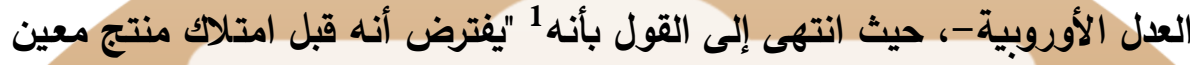

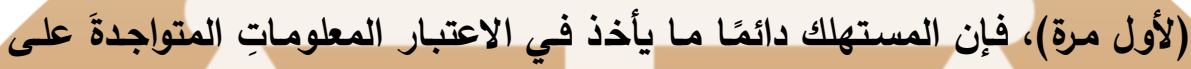

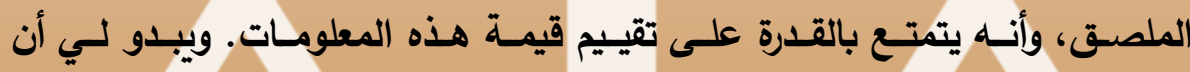

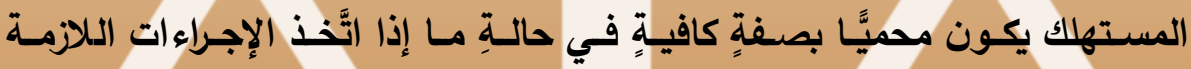

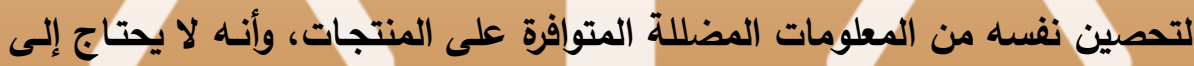

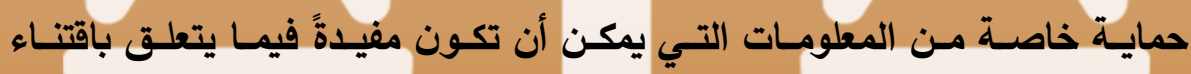

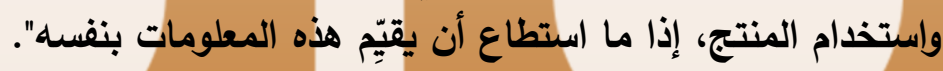

"54. It should be remembered in this context that, when assessing whether or not product information is misleading, the Court takes as its point of reference the presumed expectations of an average consumer who is reasonably well informed and reasonably observant and circumspect. This presupposes that, before acquiring a given product (for the first time), a consumer will always take note of the information on the label and that he is also able to assess the value of that information. It seems to me that a consumer is sufficiently protected if he is safeguarded from misleading

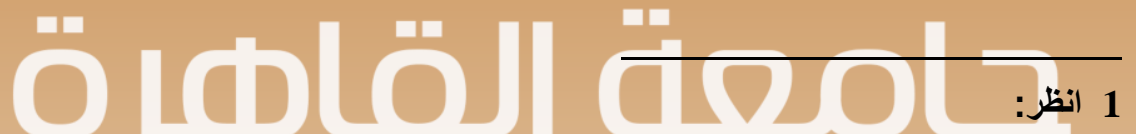

Opinion of Advocate General GEELHOED delivered on 11 December 2003, in Douwe Bgberts NV v. Westrom Pharma NV and Christophe Souranis, CASE C-239/02.

$$
\text { هذا الرأي متاح على الموقع التالي: }
$$

http://curia.europa.eu/juris/showPdf.jsf?text=\&docid=48787\&pageInde $\underline{x=0 \& \text { doclang }=\text { en \&mode }=I \text { st \&dir }=\text { \&occ }=\text { first\&part }=1 \text { \&cid }=350492}$ 
مجلة القانون والاقتصاد - ملحق خاص بمناسبة مرور مائة وخمسين عام

على إنثاء كلية الحقوق - جامعة القاهرة - العدد (الثانى والتسعون)

information on products and that he does not need to be shielded from information whose usefulness with regard to the acquisition and use of a product he can himself appraise."

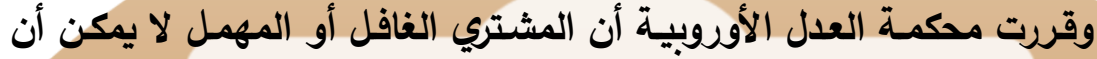

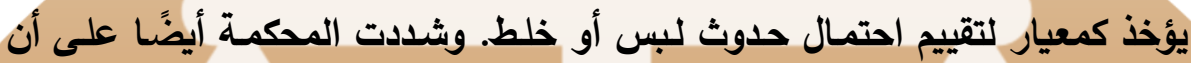

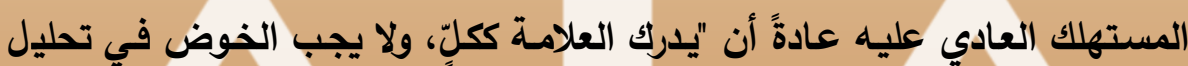
تفاصيلها".

69-... Even if similar signs are almost never perceived simultaneously by purchasers of shoes, the 'inattentive purchaser' cannot be taken as a basis for assessing the likelihood of confusion."

"25- .... The average consumer normally perceives a mark as a whole and does not proceed to analyse its various details.... "26-....However, account should be taken of the fact that the average consumer only rarely has the chance to make a direct comparison between the different marks but must place his trust in the imperfect picture of them that he has kept in his mind. It should also be borne in mind that the average consumer's level of attention is likely to vary according to the category of goods or services in question.
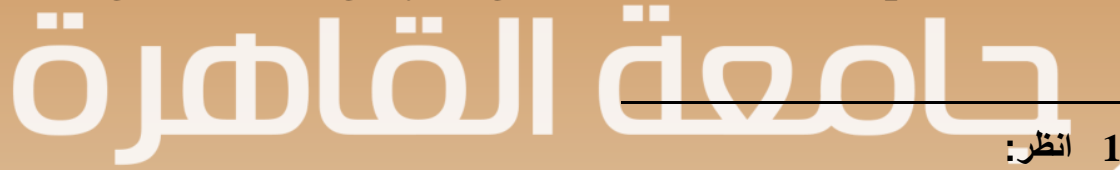

Lloyd Schuhfabrik Meyer \& Co. Gmbh v. Klijsen Handel BV, Judgement of the Court. In Case C-342/97, 22 June 1999

$$
\text { هذا القرار متاح على الموقع التالي: }
$$

http://curia.europa.eu/juris/showPdf.jsf?text=\&docid=44270\&pageIndex= $\underline{0 \text { \&doclang }=e n \& \text { mode }=1 \text { st } \& \text { dir }=\& \text { occ }=\text { first } \& \text { part }=1 \& \text { cid }=355109}$ 
وينبغي أن ينصبَّ الاهتمام على المستهلك العادي، حيث إنتا لا نميل إلى

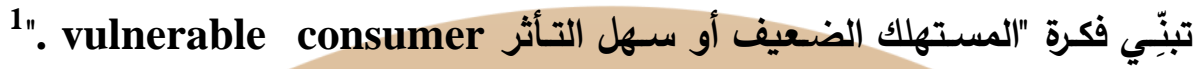

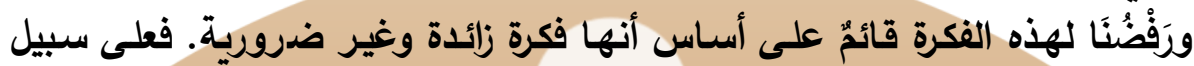

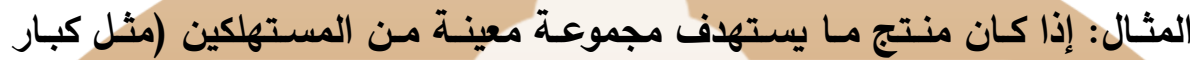

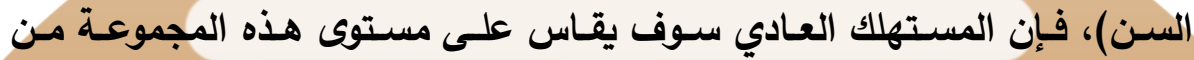
الناس، وبناءً على ذلك يكون استدعاء فكرة المستهلك الضعيف غير ضرورية.

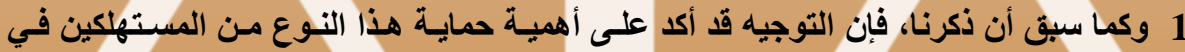

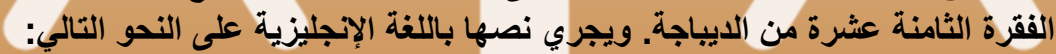
“...but also contains provisions aimed at preventing the exploitation of consumers whose characteristics make them particularly vulnerable to unfair commercial practices...."

2 انظر الفقرة الثالثة من المادة الخامسة من التوجيه. ويجري نص هذه المادة باللغة الإنجليزيـة على النحو التالي:

"Commercial practices which are likely to materially distort the economic behaviour only of a clearly identifiable group of consumers who are particularly vulnerable to the practice or the underlying product because of their mental or physical infirmity, age or credulity in a way which the trader could reasonably be expected to foresee, shall be assessed from the perspective of the average member of that group. This is without prejudice to the common and legitimate advertising practice of making exaggerated statements or statements which are not meant to be taken literally."

وانظر ايضًا الفقرة التاسعة عشرة من ديياجة التوجيه. ويجري نصها باللغة الإنجليزيـة على

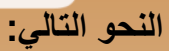

"Where certain characteristics such as age, physical or mental infirmity or credulity make consumers particularly susceptible to a commercial practice or to the underlying product and the economic behaviour only of such consumers is likely to be distorted by the practice in a way that the trader can reasonably foresee, it is appropriate to ensure that they are adequately protected by assessing the practice from the perspective of the average member of that group."

Poncibo and Incardona, op. cit., p. 329.

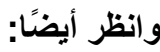


مجلة القانون والاقتصاد - ملحق خاص بمناسبة مرور مائة وخمسين عام

على إنثاء كلية الحقوق - جامعة القاهرة - العدد (الثانى والتسعون)

وتجــدر الإثـــارة إلــى أن الممارســات المــذكورة فـي القائمــة السـوداء

blacklisted practices

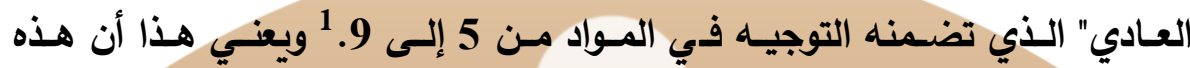

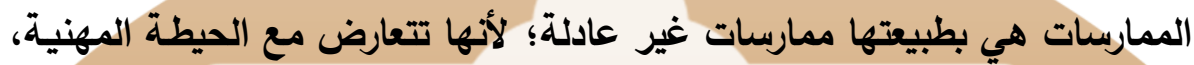

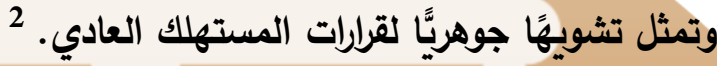
نخلص مـن هذا إلى أن المستهلك العادي هو ـوفقًا لأحكام محكمـة العدل

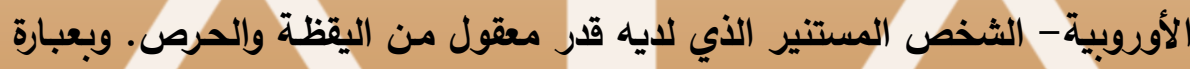
أخرى: هو المستهلك القادر على أن بحمي -بطريقة معقولئ- حقوقه.

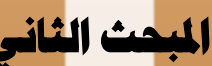

\section{التطورات الالامتة هلى إصدار توميه الممارسات التجارية} فير العادلة رقم 29 السنة 2005

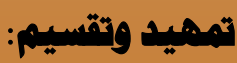

منذ صدور التوجيه الأوروبي للممارسات التجارية غير العادلة رقم 29 لسنة

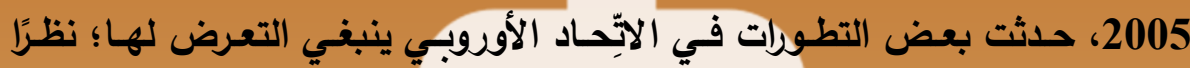

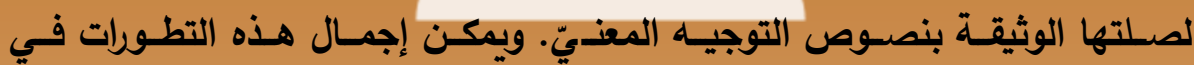

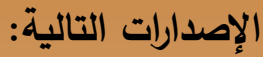
• وثيقة العمل المنشورة من قبل المفوضية الأوروبية في نهاية عام 2009 بعنوان "إرشادات بشأن تنفيذ وتطبيق التوجيه الأوروبي رقم 29 لسنة 2005

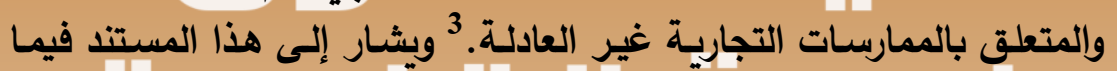

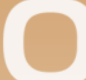

Reilly, op. cit., p. 118.

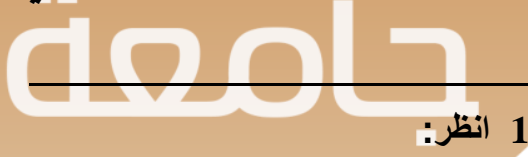

2 3

European Commission: Guidance on the Implementation/Application of Directive zoos/29/EC on Unfair Commercial practices. Brussels, 3 December 2009 SEC(2009) 1666. Available at: 
• وثيقة المفوضية الأوروبية إلى البرلمان الأوروبي والمجلس الأوروبي واللجنة

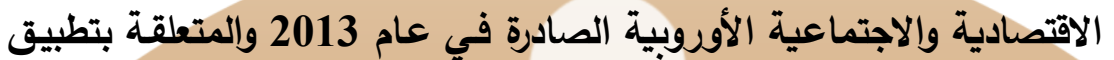

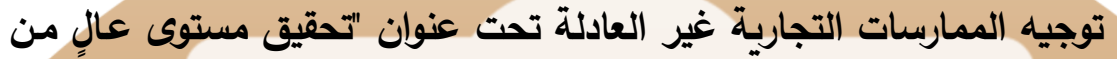

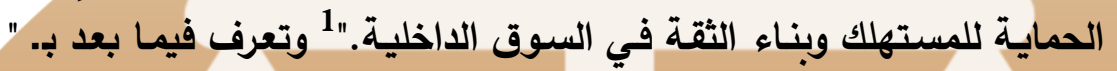
وثيقة المفوضية الأوروبية لسنة 2013".

• الوثيقـة الصـادرة مـن المفوضية الأوروبيـة في عام 2013، بعنوان "التقريـر

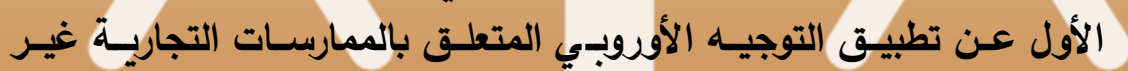

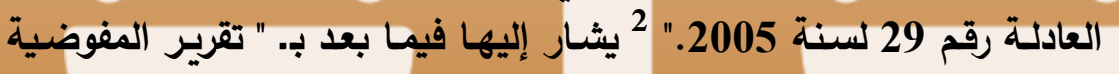

http://ec.europa.eu/justice/consumer-marketing/files/ucp guidance en.pdf تم الاطِّلاع على الموقع بتاريخ 31 مايو 2016. : 1

European Commission: "The Communication of the Commission itself to the European Parliament, the Council and the European Economic and Social Committee of 2013 on the application of the Unfair Commercial Practices Directive "Achieving a high level of consumer protection Building trust in the Internal Market." Brussels, 14.3.2013 $\operatorname{COM(2013)~} 139$ final. Available at: http://eurlex.europa.eu/legal-content/EN/TXT/?uri=celex:52013DC0138

\section{تم الاطّّلاع على الموقع بتَّريخ 31 مايو 2016.}

European Commission: "First Report on the application of Directive zoos/29/EC of the European Parliament and of the Council of 11 May 2005 concerning unfair business-to-consumer commercial practices in the internal market [...] and amending Council Directive 84/450/EEC, Directives 97/7/EC, 98/27/EC and 2002/65/EC of the European Parliament and of the Council and Regulation (EC) No 2006/2004 of the European Parliament and of the Council ('Unfair Commercial Practices Directive')." Brussels, 14.3.2013 COM(2013) 139 final." Available at: http://ec.europa.eu/justice/consumermarketing/files/ucpd_report_en.pdf 
مجلة القانون والاقتصاد - ملحق خاص بمناسبة مرور مائة وخمسين عام

على إنثاء كلية الحقوق - جامعة القاهرة - العدد (الثانى والتسعون)

الأول لسنة 2013".

• قرار البرلمـان الأوروبـي في 4 فبرايـر لسـنة 2014 المتعلق بتنفيذ توجيـه

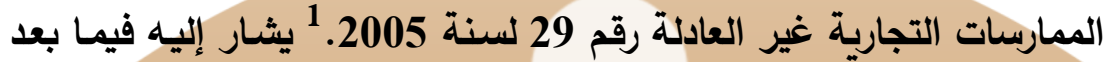

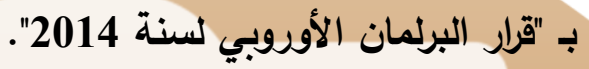

• رأي اللجنة الاقتصادية والاجتماعية الأوروبية عن مدى ضعف المستهلك في

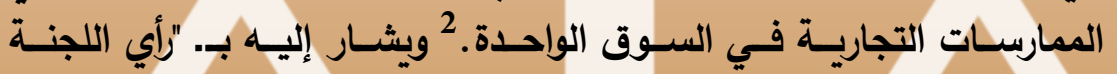

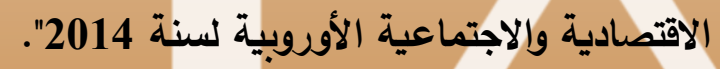

وسنتناول هذه المستندات والوثائق في المطالب التالية:

The Guidance of the المطلب الأول: إرشادات المفوضية لعام 2009

European Commission of 2009

The المطاب الثـاني: وثيقـة المفوضـية الأوروبيـة لسـنة 2013.

Communication of the European Commission of 2013

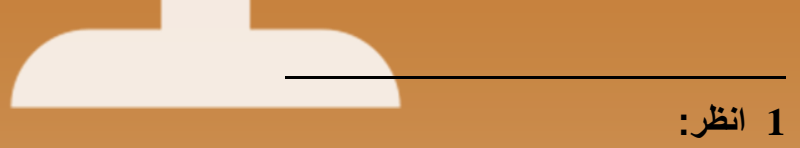

The European Parliament 'the European Parliament Resolution of 4

February 2014 on the implementation of the Unfair Commercial

Practices Directive 2005/29/EC. "Strasbourg, [2013/2116 (INI)].

Available at:

http://www.europarl.europa.eu/sides/getDoc.do?type=TA\&reference=P7-

$\underline{\text { TA-2014-0063\&language }=E N}$

تم الاطِّلاع على الموقع بتاريخ 31 مايو 2016. 2

The Opinion of the European Economic and Social Committee on Consumer vulnerability in business practices in the single market (Own-initiative opinion) 15 October 2014 (Official Journal) C12, 15 October 2015, p. 1.

Available at: http://eur-lex.europa.eu/legalcontent/EN/TXT/PDF/?uri=CELEX:52014IE1032\&from=EN

تم الاطّلاع على الموقع بتاريخ 31 مايو 2016. 

التجارية غير العادلة رقم 29 لسنة 2005 والتطورات التشريعية اللاحقة

المطلب الثالث: تقرير المفوضية الأول لسنة 2013.

Report of 2013

The Resolution . 2014 المطلب الرابع: قرار البرلمان الأوروبي لسنة of the European Parliament of 2014 المطاب الخـامس: رأي اللجنـة الاقتصـادية والاجتماعيـة الأوروبيـة لسـنة

The Opinion of the European Economic and Social . 2014 Committee of 2014.

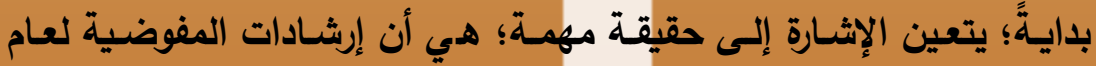

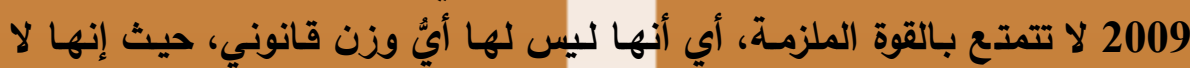

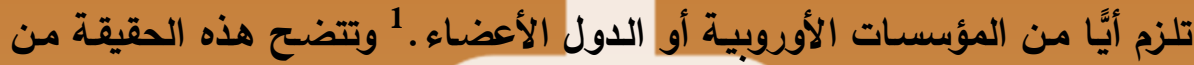

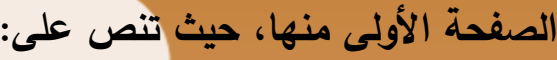

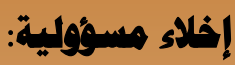

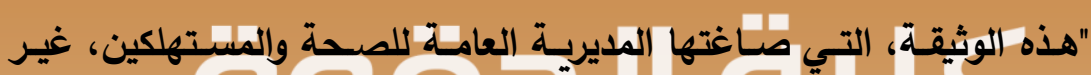

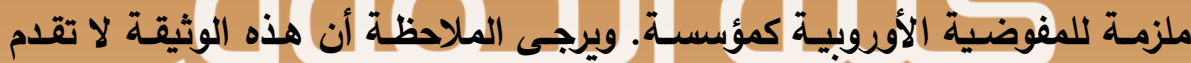

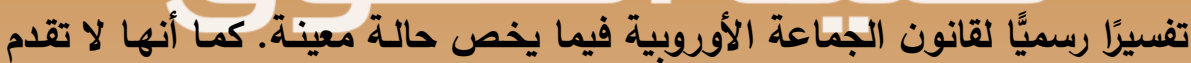

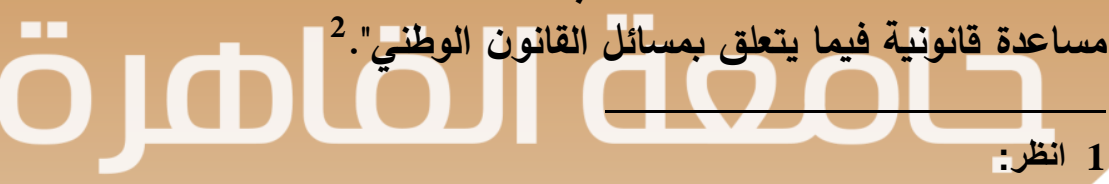

Duivenvoorde, op. cit., p. 16.

2 ويجري نصها باللغة الإنجليزية على النحو التالي:

"This document, drawn up by the services of the DirectorateGeneral for Health and Consumers, is not binding on the European Commission as an Institution. Please note that this document cannot provide a formal interpretation of community law in 
مجلة القانون والاقتصاد - ملحق خاص بمناسبة مرور مائة وخمسين عام

على إنشاء كلية الحقوق - جامعة القاهرة - العدد (الثانى والتسعون)

وبالإضافة إلى ذلك، فإن مقدمة إرشادات المفوضية لسنة 2009 تنص على

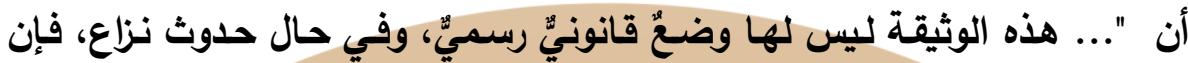

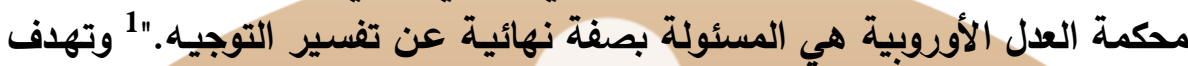
إرشـادات المفوضـية لسـنة 2009 إلـى تقـديم إرثـادات بثــأن المفـاهيم والأحكـام

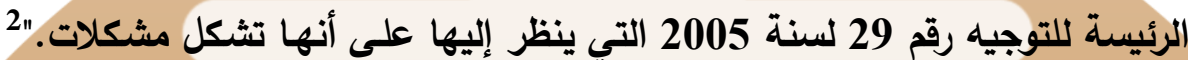
"وهي تشتمل على أمثلة عملية تهدف إلى تسهيل عمل التوجيه؛ وذلك من أجل تحقيق "... فهم مشترك وتقارب للممارسات عند تنفيذ وتطبيق التوجيه."3

وتشير الإرشـادات إلى العديـ من الأمور، منها نطاق التطبيق.وفي هذا

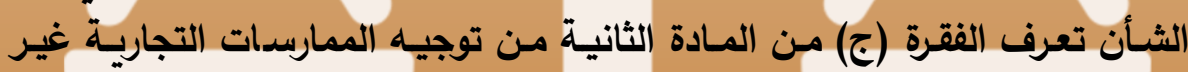

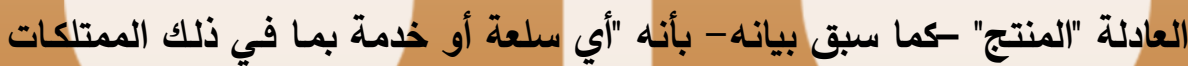

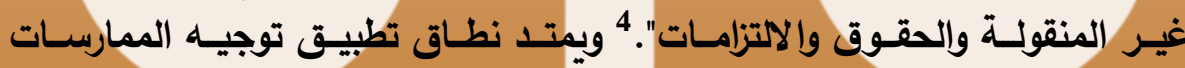

relation to a specific situation. It also does not provide legal advice on issues of national law".

1 انظر مقدمة إرشادات المفوضية لسنة 2009، المرجع السـابق، ص 6. ويجري نصـها باللغـة

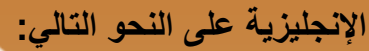

"...this document has no formal legal status and in the event of a dispute, the ultimate responsibility for the Directive's interpretation lies with the Court of justice of the European Union."

2 انظر مقدمة إرثشادات المفوضية لهنة 2009، المرجع السـابق، ص 6. ويجري نصـها باللغـة "...aims at providing guidance on the key concepts and provisions of the Directive perceived to be problematic."

3 انظر مقدمة إرشادات المفوضية لسنة 2009، المرجع المسابق، ص 6. ويجري نصـها باللغـة الإنجليزية على النحو التالي:

"It includes practical examples showing how this Directive works. The guidance aims at developing a common understanding and a convergence of practices when implementing and applying the Directive."

$$
4 \text { ويجري نصها باللغة الإنجليزية على الندو التالي: }
$$

"'product' means any goods or service including immovable property, rights and obligations." 
التجارية التي يستخدم فيها الإنترنت والتي تحدث على مواقع التواصل الاجتمـاعي

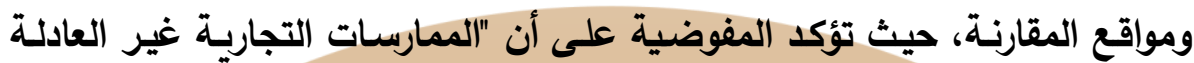

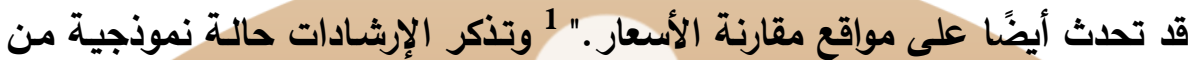

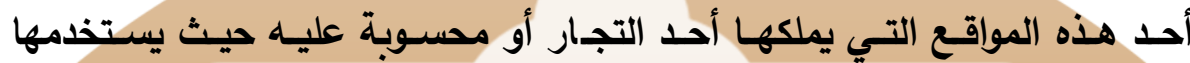

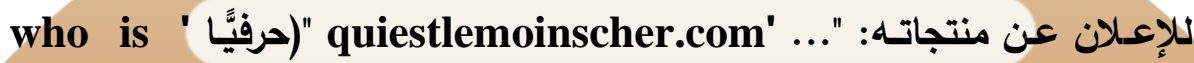

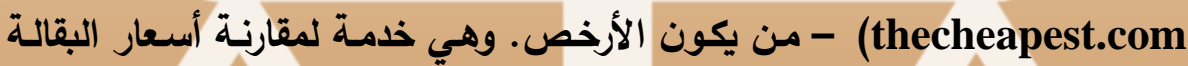

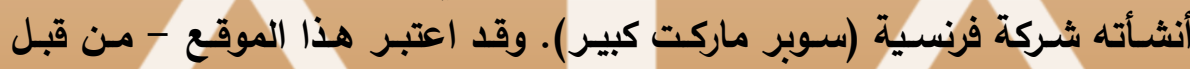
المحاكم الفرنسية- كموقع للتاجر وأداة للدعاية المقارنة. 2 وبتكون نشاط التاجر في حالة مواقع الإنترنت التي تقوم بمقارنة الأسعار من

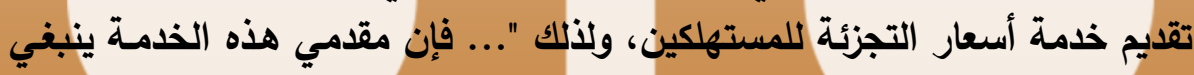

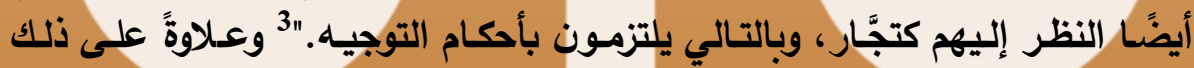

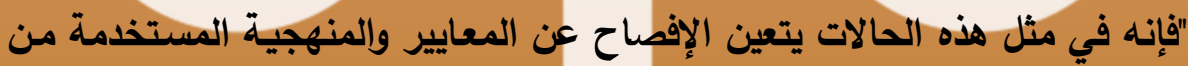
قبل مقدمي هذه الخدمات....".

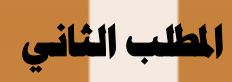

\section{وثيقة الففوضية الأورفبية لسنة 2013}

The Communication of the EU Commission of 2013

صدرت وثثيقة المفوضية الأوروبية إلى البرلمان الأوروبي والمجلس الأوروبي

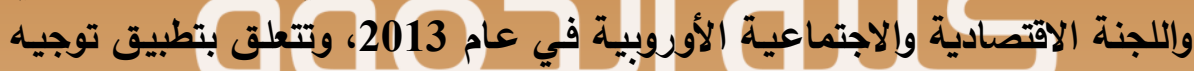

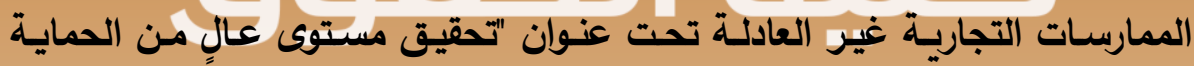

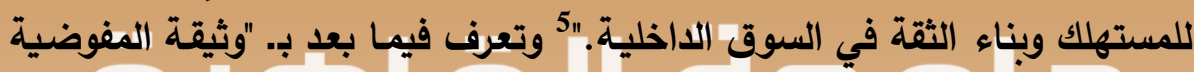

و انظر أيضًا البند 1 "نطاق تطبيق التوجيه" من إرشادات المفوضية لسنة 2009.

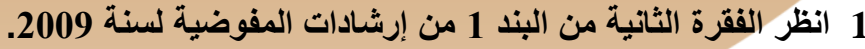

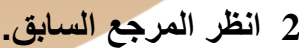
3 انظر المرجع السابق. 4 
مجلة القانون والاقتصاد - ملحق خاص بمناسبة مرور مائة وخمسين عام

على إنثاء كلية الحقوق - جامعة القاهرة - العدد (الثانى والتسعون)

الأوروبية لسنة 2013". واحتوت هذه الوثيقة على الاستنتاجات الرئيسـة التي أمكن

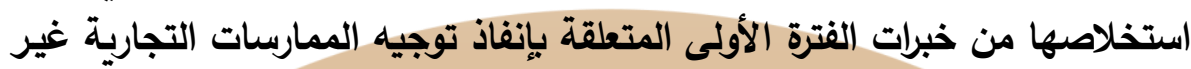

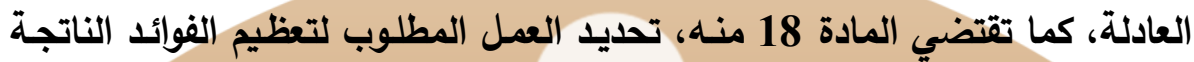

من التوجيه بالنسبة للسوق الموحدة الأوروبية وحماية المستهلك. حيث كان - ومـا

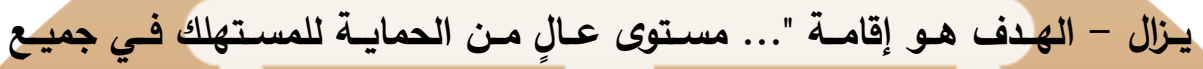

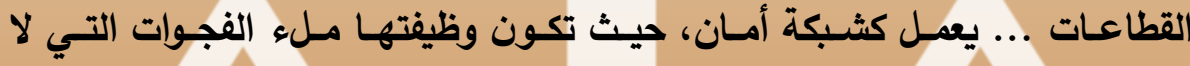

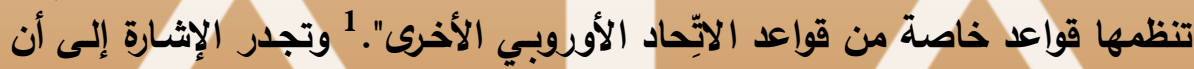

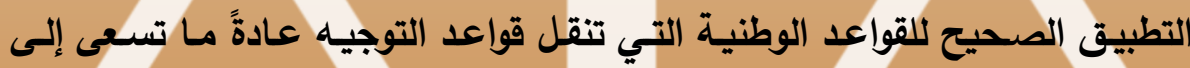

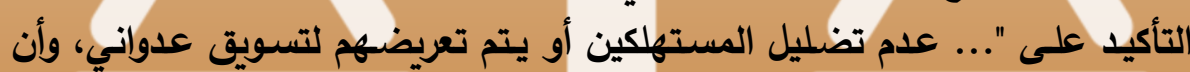

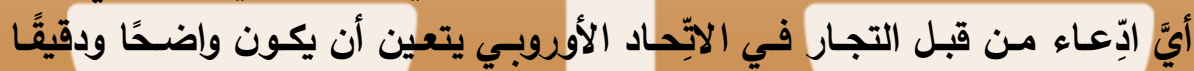

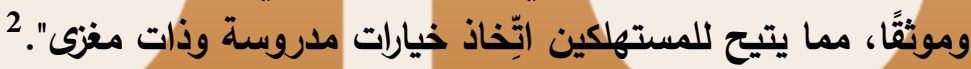

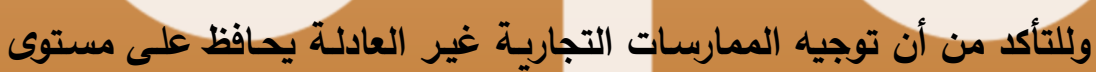

European Commission: "The Communication of the Commission itself to the European Parliament, the Council and the European Economic and Social Committee of 2013 on the application of the Unfair Commercial Practices Directive "Achieving a high level of consumer protection Building trust in the Internal Market." Brussels, 14.3.2013 COM(2013) 139 final. Available at: http://eurlex.europa.eu/legal-content/EN/TXT/?uri=celex:52013DC0138

$$
\begin{aligned}
& \text { تم الاطِّلاع على الموقع بتَاريخ } 31 \text { مايو } 2016 . \\
& 1 \text { انظر مقدمة الوثيقة. ويجري نص هذئر هذه الفقرة باللغة الإنجليزية على النحو التالي: }
\end{aligned}
$$

"This Communication outlines the main conclusions which can be drawn based on the initial period of experience in enforcing the Unfair Commercial Practices Directive, as required by its Article 18, and sets out what action is needed to maximise the benefits of the Directive for Single Market integration and consumer protection." 2 انظر مقدمة الوثيقة. ويجري نص هذه الفقرة باللغة الإنجليزية على النحو التالي:

"It ensures that consumers are not misled or exposed to aggressive marketing and that any claim made by traders in the EU is clear, accurate and substantiated, thus enabling consumers to make informed and meaningful choices." 
عالٍ من الحماية للمستهلك ويحقق فوائده للسوق الموحدة، فيتعين أن يتم تكثيف إجراءات الإنفاذ الوطني والتشديد على التعاون في إجراءات الإنفاذ العابـات العابرة للحدود.

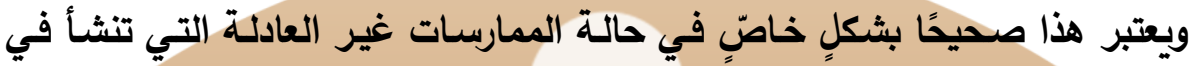

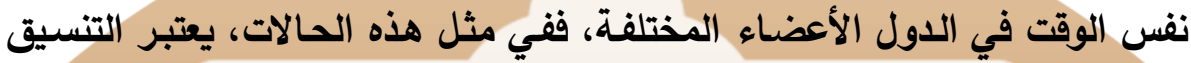
الفعال بين المفوضية والسلطات الوطنية ومنظمات المستهلكين وأصحاب الأعمال عاملاً أساسيَّا لمواجهة الممارسات التي لها تأثير على نطاق الآِّحاد الأوروبي. ولضـمان أن يـتم تطبيق التوجيـه الأوروبـي رقـم 29 لسنة 2005 بطريقـة

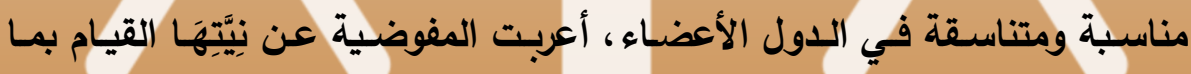
• تطوير وثيقة إرشادات المفوضية لعام 2009، وذلك ردَّا على المداخلات التي

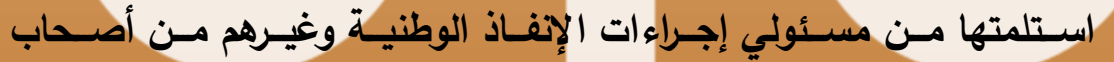

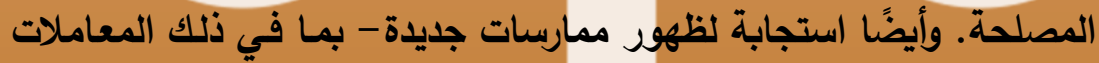

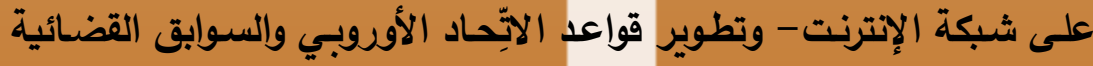
الوطنية. • تصسـين وتوسـيع وتحـديث قاعـدة البيانـات المتعلقـة بتوجيــه الممارسـات التجاربة.

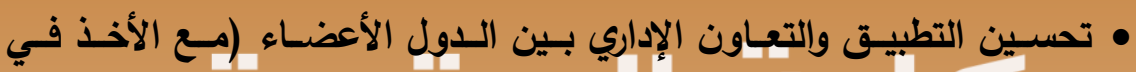

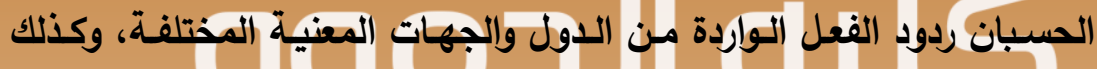

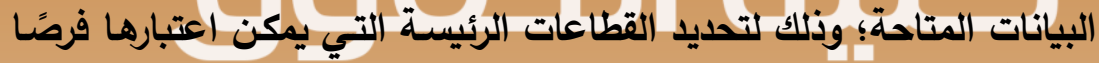

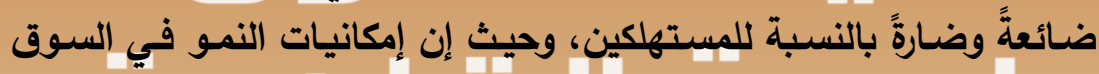

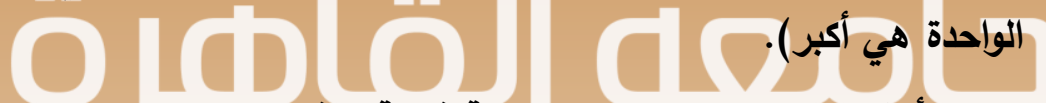
- من أجل رصد تطوير السوق بطريقة فعالة ورفع مستوى الوعي، التزمت

Vaque, op. cit., p. 215. 1 
مجلة القانون والاقتصاد - ملحق خاص بمناسبة مرور مائة وخمسين عام

على إنثاء كلية الحقوق - جامعة القاهرة - العدد (الثانى والتسعون)

$$
\text { المفوضية بالقيام بما يلي:1 }
$$

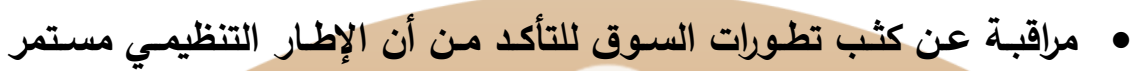

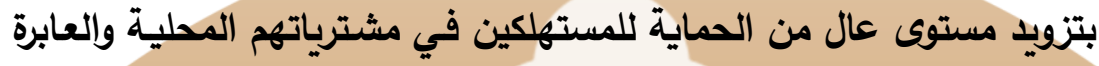

$$
\text { للحدود. }
$$

• التركيز بشكل خـاص على مـدى ملاءمـة الإطـار القـانوني لمواكبـة التطور

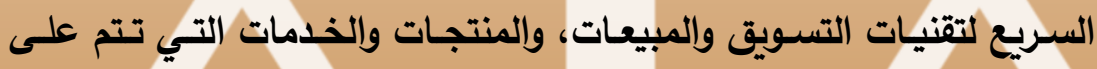

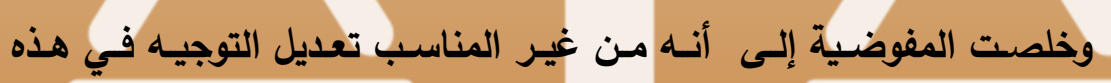

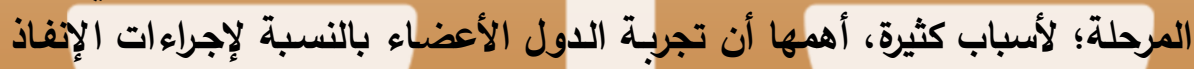

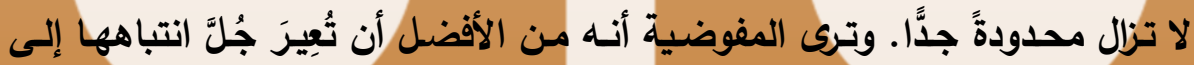

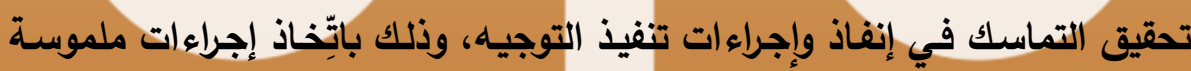

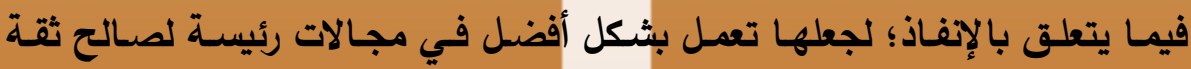

المستهلكين والنمو.

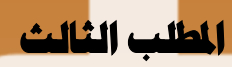

تقرير الفموضية الأول لسنة 2013

The First Report of 2013

نشرت المفوضية في عام 2013 أيضًا تقريرها الأول تحت عنوان "التقريـر

الأول عن تطبيق التوجيه الأوروبي المتعلق بالممارسـات التجارية غير العادلة رقم

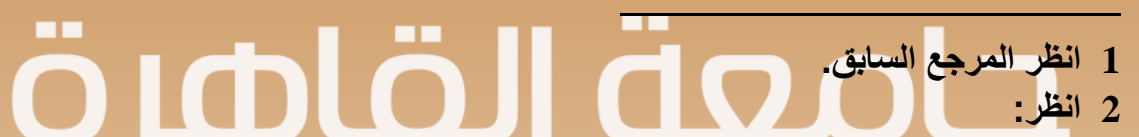

"The Commission considers that it would be inappropriate to amend the Directive at this stage, not least because the enforcement experience in the Member States is still too limited in time for such an encompassing body of legislation. The Commission will now focus its attention on the coherence of the implementation of the Directive, taking concrete actions to make enforcement work better in key areas to the benefit of consumer confidence and growth." 

التجارية غير العادلة رقم 29 لسنة 2005 والتطورات التشريعية اللاحقة

29 لسنة 2005." 1 يثار إليه فيمـا بعد ب. "تقرير المفوضية الأول لسنة 2013". وتعتبر هاتـان الوثيقتان (وثيقة المفوضية لعام 2013 والتقرير الأول لعام 2013)

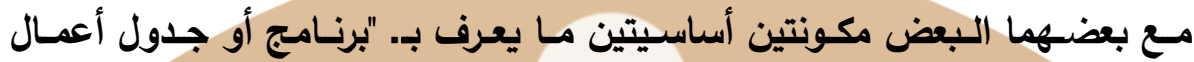

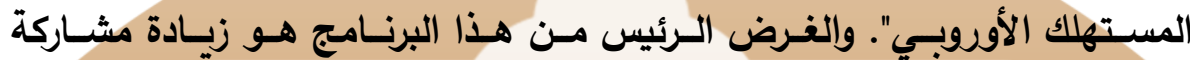
المستهلكين وتعزيز الثقة في السوق، وبالتالي تعزيز النمو.2

عالج هذا التقرير كثيرًا من الموضوعات المهمة في هذا المجال، منها تنفيذ

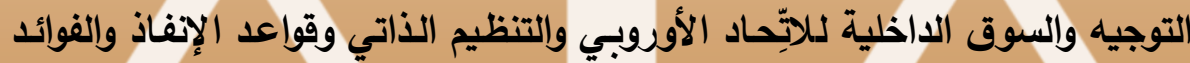

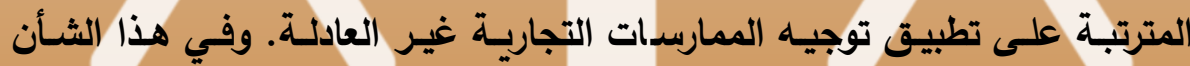

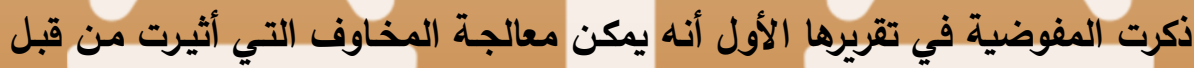

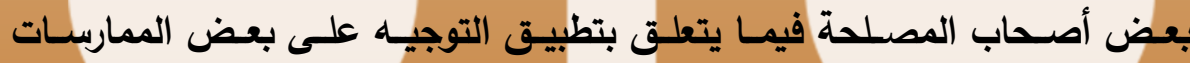

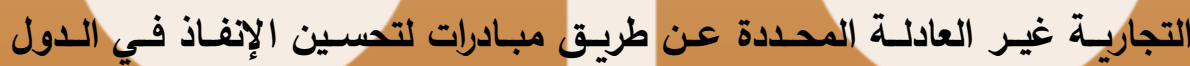

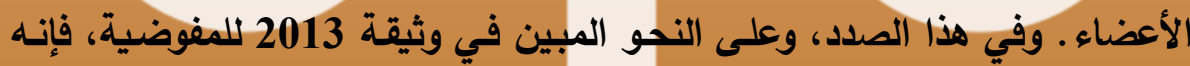

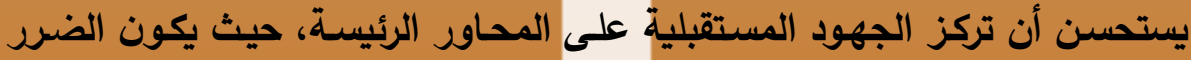

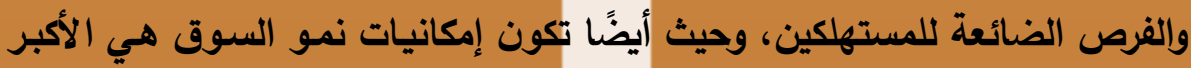

European Commission: "First Report on the application of Directive zoos/29/EC of the European Parliament and of the Council of 11 May 2005 concerning unfair business-to-consumer commercial practices in the internal market $[. .$.$] and amending Council Directive$ 84/450/EEC, Directives 97/7/EC, 98/27/EC and 2002/65/EC of the European Parliament and of the Council and Regulation (EC) No 2006/2004 of the European Parliament and of the Council ('Unfair Commercial Practices Directive')." Brussels, 14.3.2013 COM(2013) 139 final." Available at: http://ec.europa.eu/justice/consumermarketing/files/ucpd report en.pdf

$$
2 \text { انظر: الاطِّلاع على الموقع بتاريخ } 31 \text { مايو } 2016 .
$$

Vaque, op. cit., p. 215.

3 انظر خاتمة التقرير الأول للمفوضية الصادر عام 2013، ص 31. 
مجلة القانون والاقتصاد - ملحق خاص بمناسبة مرور مائة وخمسين عام

على إنثاء كلية الحقوق - جامعة القاهرة - العدد (الثانى والتسعون)

\section{المالب الرابع}

\section{قرار البرلمان الأوروبي لسنة 2014}

Parliament of 2014 The Resolution of the European

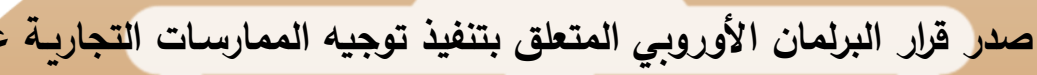

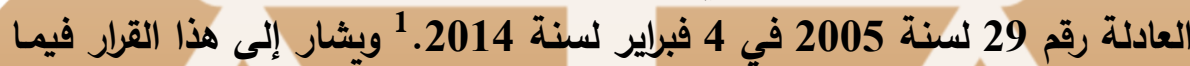

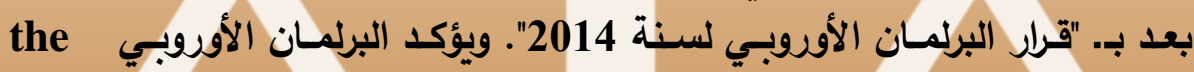

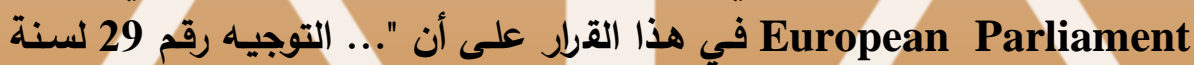

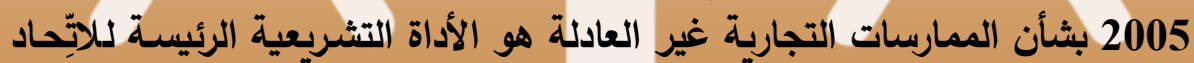

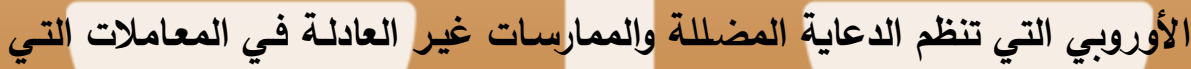

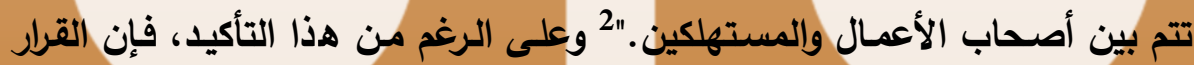

"The concerns which have been raised by some stakeholders in relation to the application of the UCPD to certain specific unfair commercial practices can be addressed by initiatives to improve enforcement in the Member States. In this connection, as outlined in the Communication, future efforts will need to concentrate on key thematic areas where detriment and lost opportunities for consumers appear to be most frequently recurring and where the Single Market's growth potential is the biggest."

The European Parliament 'the European Parliament Resolution of 4 February 2014 on the implementation of the Unfair Commercial Practices Directive 2005/29/EC. "Strasbourg, [2013/2116 (INI)]. Available http://www.europarl.europa.eu/sides/getDoc.do?type=TA\&reference=P7$\underline{T A-2014-0063 \& \text { language }=E N}$

$$
\text { تم الاطِّلاع على الموقع بتاريخ } 31 \text { مايو } 2016 .
$$

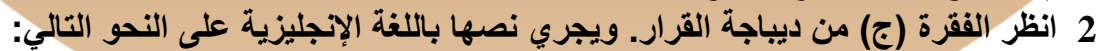

“C. whereas Directive 2005/29/EC on unfair commercial practices is the European Union's main legislative tool regulating misleading advertising and other unfair practices in business-to-consumer transactions." 
ذاته ينص على وجود فروق واختلافات كبيرة في تنفيذ التوجيه من دولـة إلى أخرى

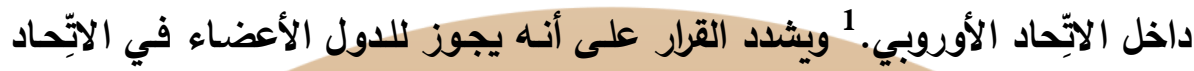

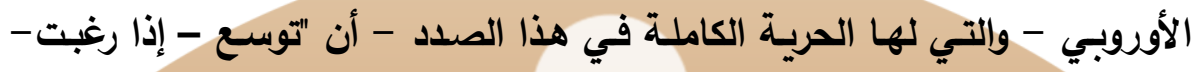
في نطاق تطبيق التوجيه ليشمل المعاملات التي تتم بين أصحاب الأعمـال وغيرهم

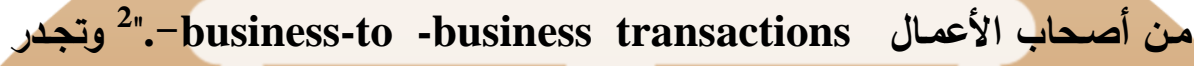
الإثارة إلى أن أربع دول فقط اختارت أن تفعل ذلك. 3 ويؤكد البرلمـان الأوروبي في

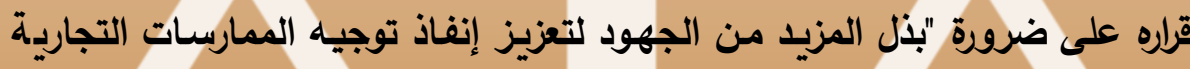

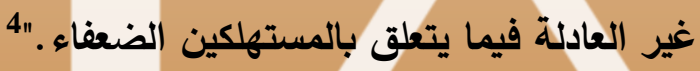

وتجدر الإثارة إلى أن البرلمان الأوروبي تحقق من وجود العديد من الأمور التي يتعين العدول عنها، منها:

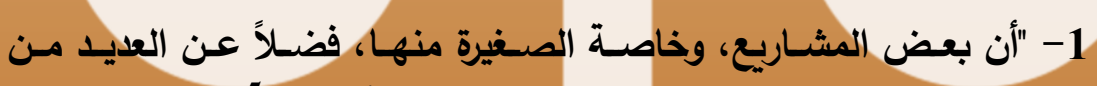
المستهاكين، ليس لديهم علمُ كافٍ بحقوق المستهالك في أوروبا."

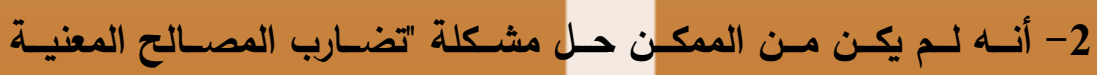
1 انظر الفقرة (0) من ديباجة القرار التي تنص باللغة الإنجليزية على الآتي: "E. whereas there have been major differences in the implementation of Directive 2005/29/EC from one Member State to another."

$$
2 \text { انظر الفقرة (ز) من ديباجة القرار التي تنص باللغة الإنجليزية على الآتي: }
$$

"G. whereas Member States which so wish are free to extend application of the Directive to business-to-business relations, and whereas to date only four Member States have chosen to do so."

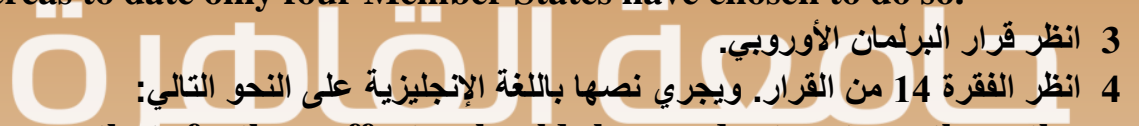

"Agrees that further efforts should be made to strengthen the enforcement of the Unfair Commercial Practices Directive in relation to vulnerable consumers."

$$
5
$$

"whereas some undertakings, particularly the smaller ones, as well as many consumers, are still insufficiently aware of consumers' rights in Europe." 
مجلة القانون والاقتصاد - ملحق خاص بمناسبة مرور مائة وخمسين عام

على إنثاء كلية الحقوق - جامعة القاهرة - العدد (الثانى والتسعون)

والاسـتخدام المضـلل الـذي يقـوم بـهـ بعض التجـار حيـث يضـعون أدوات مراجعـة

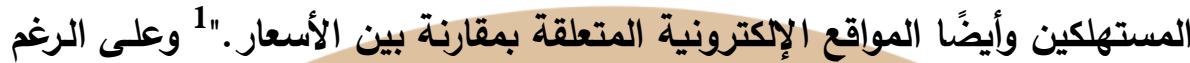

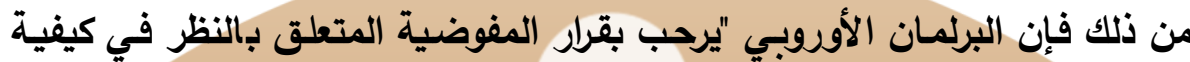

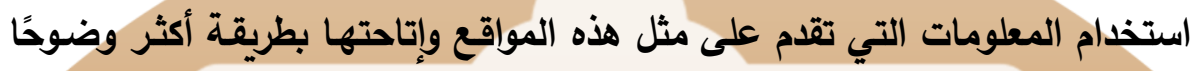

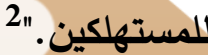

3- أن "استخدام المطالبات البيئية الكاذبة يعتبر ممارسدة غير عادلة، وهي

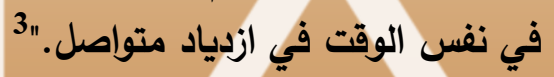

ويتبنى البرلمان الأوروبي في هذا القرار العديد من التوصيات، منها:

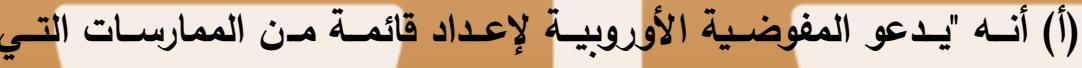

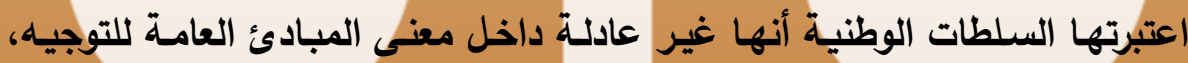

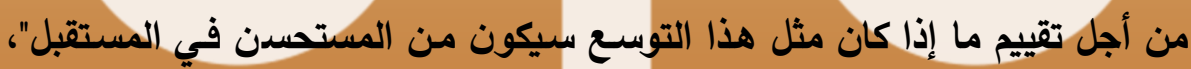

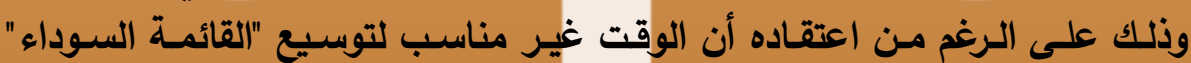

المتواجدة في المرفق الأول للتوجيه.

$$
1 \text { انظر الفقرة } 15 \text { من القرار التي تنص على الآتي: }
$$

"Expresses concern at the conflicts of interest involved and the misleading use to which some traders are putting customer review tools and price comparison websites; welcomes the Commission's decision to consider how the information provided on such platforms might be made clearer to consumers."

2

3

"...the use of false environmental claims is an unfair practice which is on the rise;..."

4 انظر الفقرة رقم 5 من القرار التي يجري نصها باللغة الإنجليزية على النحو التالي:

"Considers that it would not be appropriate at this stage to expand the black list in Annex I; calls however on the Commission to draw up a list of practices which national authorities have identified as unfair within the meaning of the general principles of the Directive, in order to assess whether such an expansion would be advisable in the future." 
(ب) أنه في ضوء الحقيقة المؤكدة أنه منذ 12 يونيو 2013، لـ يَعُدْ مقبولاً

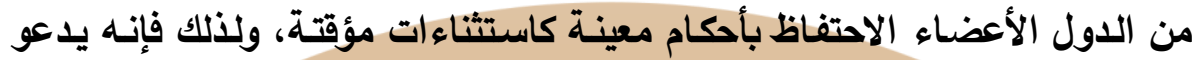

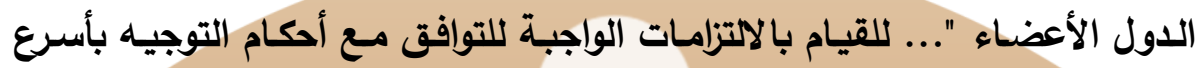
وقت ممكن. "1"

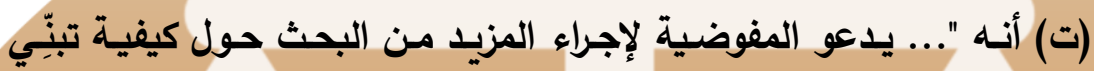

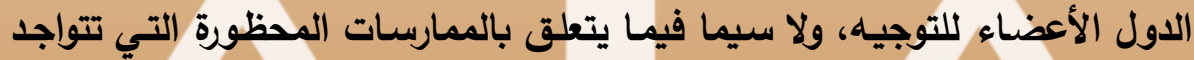

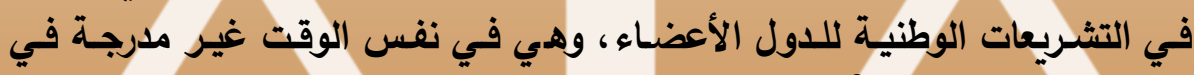

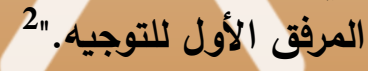

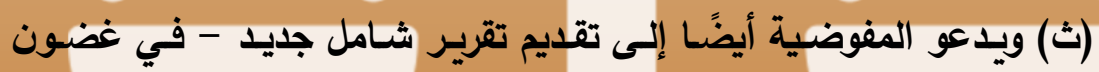

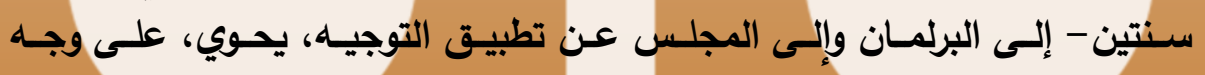

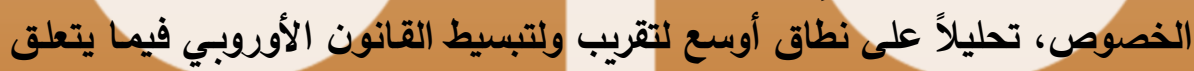

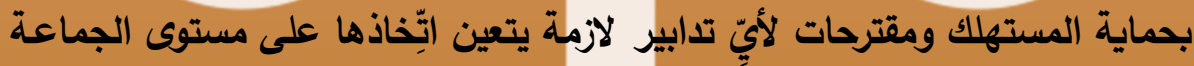

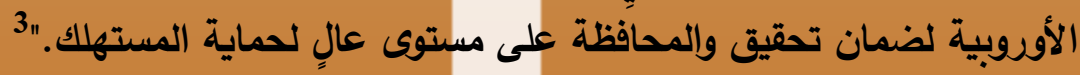
(ج) أنـه "لاحظظ أنـه منـذ انتهـاء المهالة الزمنيـة لتطبيق التوجيـه في عام

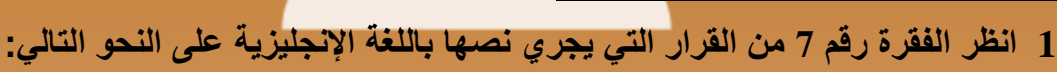
"Recalls that, with effect from 12 June 2013, Member States may no longer maintain the provisions retained until that date as temporary derogations;...."

2 انظر الفقرة رقم 7 من القرار التي يجري نصها باللغة الإنجليزية على النحو الثالي: “...calls on the Commission to carry out research into how Member States have transposed the Directive, in particular regarding national prohibitions not included in Annex I...."

3 انظر الفقرة رقم 7 من القرار التي يجري نصها باللغة الإنجليزية على النحو التالي: “... and to submit within 2 years to Parliament and to the Council a new comprehensive report on its application, containing, in particular, an analysis on the scope for further harmonisation and simplification of Community law relating to consumer protection and suggestions for any necessary measures to be taken at Community level to ensure that a high level of consumer protection is maintained...." 
مجلة القانون والاقتصاد - ملحق خاص بمناسبة مرور مائة وخمسين عام

على إنشاء كلية الحقوق - جامعة القاهرة - العدد (الثانى والتسعون)

2007 كان هناك العديد من الحالات من الدول الأعضاء، حيث قامت هذه الدول -

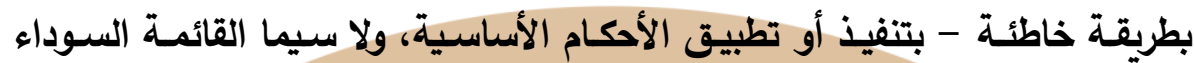

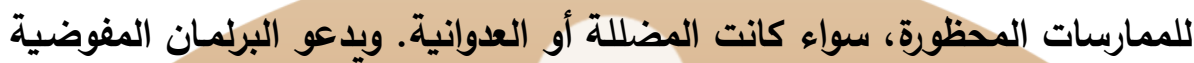

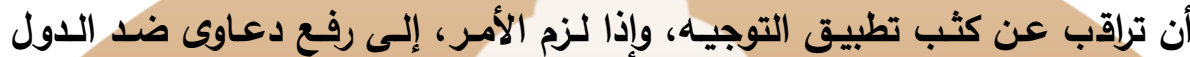
الأعضاء التي تنتهك التوجيه أو تفشل في تنفيذه أو تطبيقه بثكل صحيح....".

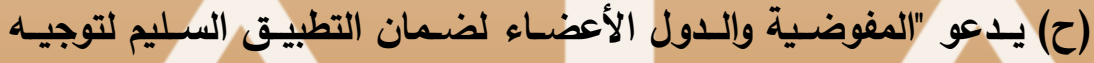

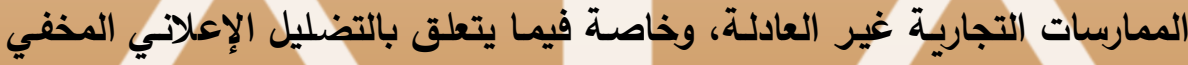

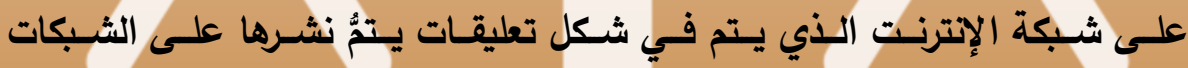

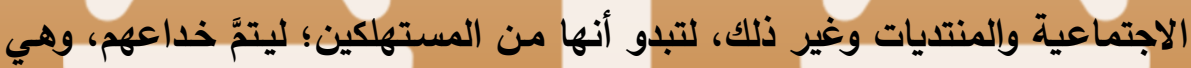
في الحقيقة ذات طابع تجاري أو إعلاني". 2

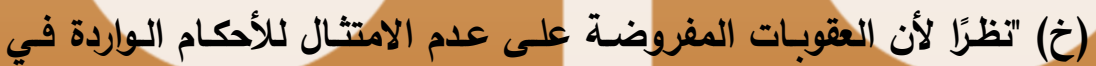

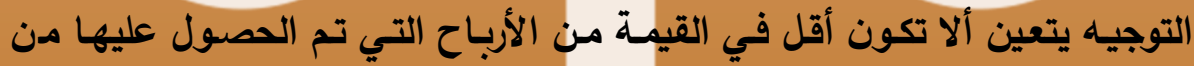

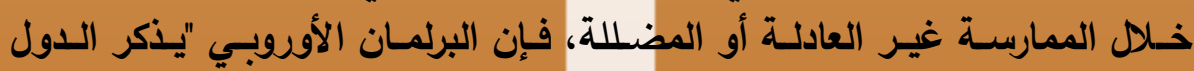

$$
1 \text { انظر الفقرة رقم } 9 \text { من القرار التي تنص على: }
$$

"Notes that, since the expiry of the deadline for implementation of the Directive in 2007, there have been numerous cases of Member States not correctly implementing or applying key provisions, in particular the black list of banned, misleading and aggressive commercial practice; calls therefore on the Commission to continue monitoring closely application of the Directive and, if necessary, to bring proceedings against Member States which infringe the Directive or fail to implement it or to apply it correctly...."

2 انظر الفقرة رقم 16 من القرار التي تنص باللغة الإنجليزية على الآتي:

"Calls on the Commission and the Member States to ensure proper application of the Unfair Commercial Practices Directive especially regarding misleading 'hidden' internet advertising in the form of comments posted on social networks, forums or blogs, apparently emanating from consumers themselves while they are in reality messages of a commercial or advertising nature directly or indirectly generated or financed by economic operators;...." 
التجارية غير العادلة رقم 29 لسنة 2005 والتطورات التثريعية اللاحقة

الأعضـاء بـأن التوجيـه ينص على أن العقوبـات يجب أن تكون فعالـةً ومتناسبةً

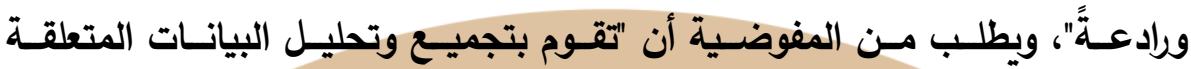

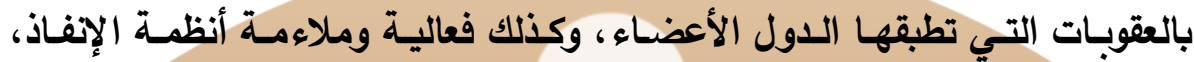

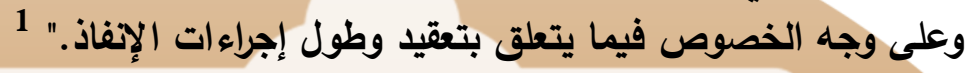

\section{رأي البهنة الاقتمادية والاجتماعية الأورفية السنة 2014}

The Opinion of the European Economic and Social Committee of 2014.

وافقت اللجنة الاقتصادية والاجتماعية الأوروبية في أكتوبر 2014 على رأي

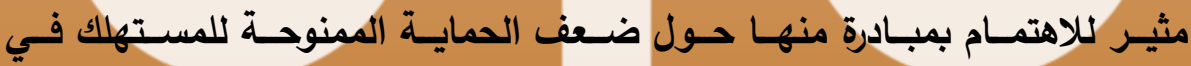

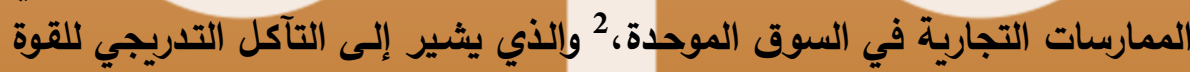

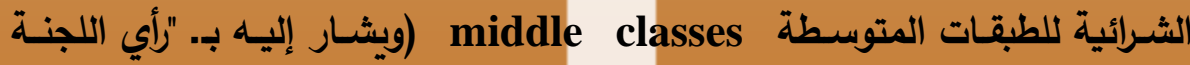

$$
1 \text { انظر الفقرة رقم } 19 \text { من التوجيه التي تجري على النحو التالي: }
$$

"Considers that the penalties imposed for failure to comply with the Directive ought never to be lower in value than the profit made through a practice deemed to be unfair or misleading; reminds Member States that the Directive states that penalties must be effective, proportionate and dissuasive; asks the Commission to compile and analyse data on penalties applied by Member States as well as on the efficiency of enforcement regimes in particular with regard to the complexity and length of enforcement procedures; calls on the Commission to provide the Parliament with results of these analyses."

the Opinion of the European Economic and Social Committee on Consumer vulnerability in business practices in the single market (Own-initiative opinion) 15 October 2014 (Official Journal) C12, 15 October 2015, p. 1. Available at: http://eur-lex.europa.eu/legalcontent/EN/TXT/PDF/?uri=CELEX:52014IE1032\&from=EN 
مجلة القانون والاقتصاد - ملحق خاص بمناسبة مرور مائة وخمسين عام

على إنثاء كلية الحقوق - جامعة القاهرة - العدد (الثانى والتسعون)

الاقتصادية والاجتماعية الأوروبية لسنة 2014"). وعرفت اللجنة الطبقة المتوسطة

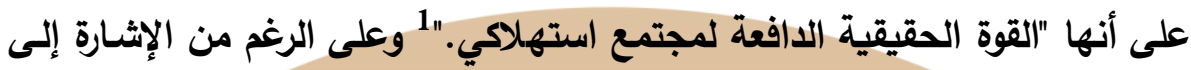

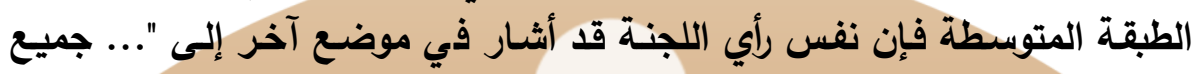
المستهلكين بصفة عامة."2

ويرجع اهتمام الجنة بهذا الأمر نظرًا لتعلقه الوثيق بالأزمة الاقتصادية. فمن

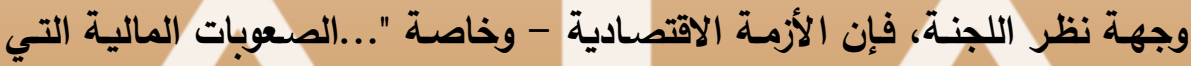

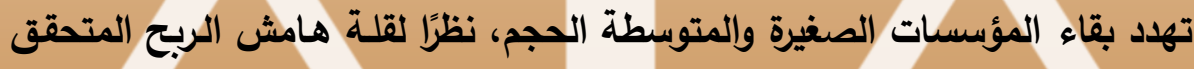

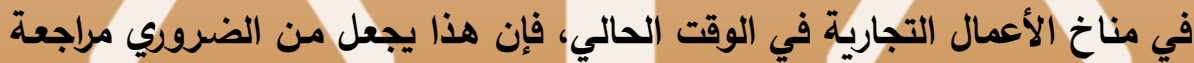

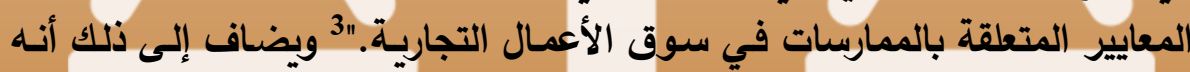

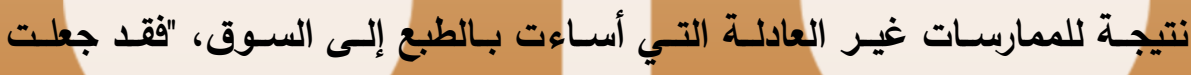

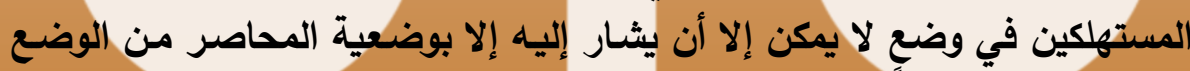

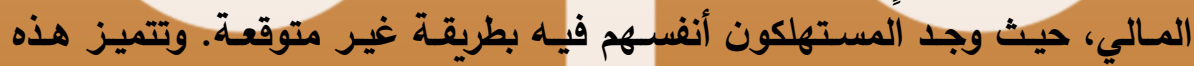

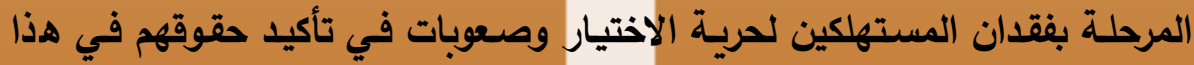

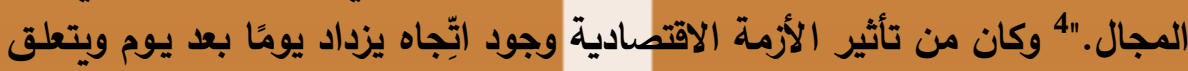

1 انظر الفقرة الأولى من البند رقم 1 من رأي اللجنة. ويجري نص هذه الفقرة باللغة الإنجليزيـة

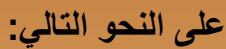

"The gradual erosion of the purchasing power of the middle classes - the real drivers of consumer society - and of all consumers in general, ...." (emphasis added).

Vaque, op. cit., p. 218.

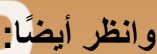

2 النظر الفقرة الأولى من البندان. رقم 1 من مرأي اللجنة. ويجري نصها باللغة الإنجليزية على النحو

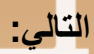

"....and the financial difficulties threatening the very survival of small and medium-sized enterprises, given the tight profit margins in the current business climate, have made it necessary to review standard commercial market practices." "

4 انظر الفقرة الثانية من البند رقم 1 من رأي اللجنة. وتنص باللغة الإنجليزية على النحو التالي:

" The knock-on effects of the market distortions caused by unfair practices have led to the emergence of consumers trapped by the 
بانخفاض عدد المستهلكين المستقبلين، ومسن المتوقـع استمرار هذا المؤشـر في<smiles>[14CH3][AlH2]</smiles>

وتجدر الإثـارة إلى أن اللجنة الاقتصـادية والاجتماعية قد عبرت عن قلقها

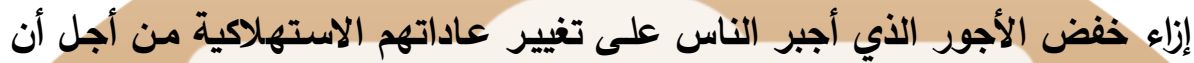

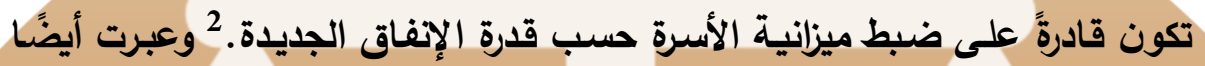

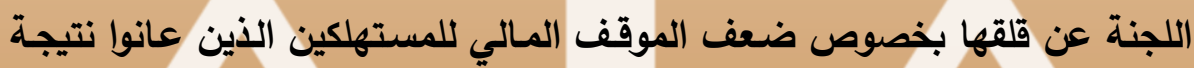

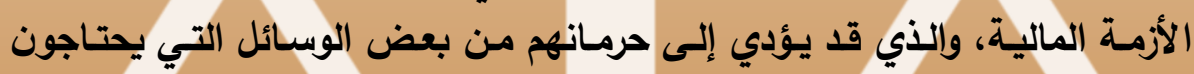

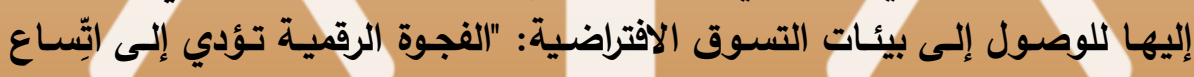
الفجوة الاجتماعية." - 3

financial situation they find themselves in unexpectedly, characterised by a loss of freedom of choice and difficulties in asserting their rights in this area. These consumers should also be shielded from the effects of these policies, to prevent them falling victim to exclusion." 1 انظر الفقرة الثالثة من البند رقم 1 من رأي اللجنة. وتنص باللغة الإنجليزية على النحو التالي: " ... the economic crisis has led to a widespread and ongoing trend for the gradual weakening of potential consumers, which suggests that this fall in consumption could continue to grow.... "

2 انظر الفقرة الثانية من البند رقم 2 من رأي اللجنة التي يجري نصـها باللغـة الإنجليزيـة على

"Wage cuts have obliged people to change their consumer ho النحو التالي: that they are able to adjust their household budget to their new spending capacity."

3

" Similarly, the weak financial position of consumers whose finances have suffered as a result of the crisis denies them some of the means they need to access virtual marketing environments, which in turn makes it harder for them to access the market in goods and services on more favourable terms. The 'digital divide' is thus widening the 'social divide', because consumers are finding it harder to protect themselves against the risks arising from the effects of the economic crisis and the complexity of digital markets." 
مجلة القانون والاقتصاد - ملحق خاص بمناسبة مرور مائة وخمسين عام

على إنشاء كلية الحقوق - جامعة القاهرة - العدد (الثانى والتسعون)

وتجــر الإثـارة إلـى أن هنـاك بعض التــابير أو الإجـراءات التـي يتعـين

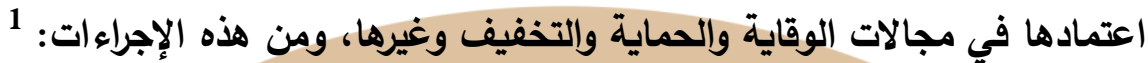

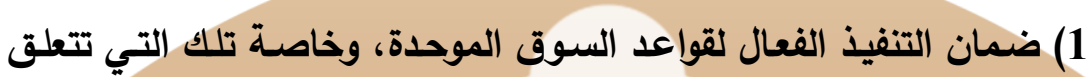

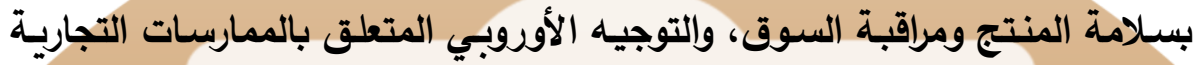

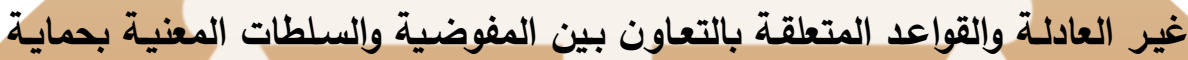

2) دعم وتكملة والإشـراف على سياسـات الدول الأعضـاء في مجال حمايـة

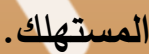

3) مراقبة الحواجز الجديدة التي ظهرت والتي أعاقت عمل السوق الموحدة، مثل وقوع المستهلكين ضحية نتيجة للقوة الاقتصادية عند إبرام العقود.

ومن جانبهم، ينبغي على الدول الأعضداء ${ }^{2}$ ان تقدم لجمعيات المستهلكين

1 انظر الفقرة الخامسة من البند رقم 1 من رأي اللجنة التي يجري نصها باللغة الإنجليزية على

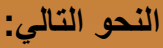

"Measures by the European institutions aimed at:

1) ensuring more effective implementation of the single market rules, especially those concerning product safety and market surveillance, the Directive on unfair commercial practices and the Regulation on cooperation between the Commission and consumer authorities;

2) supporting, supplementing and supervising Member State policies in the area of consumer protection; 3) monitoring the new barriers that have emerged, hampering the functioning of the internal market, such as consumers falling victim to economic violence when concluding contracts and other issues, taking the appropriate steps to dismantle such barriers properly"

2 انظر الفقرة الخامسة من البند رقم 1 من رأي اللجنة التي يجري نصها باللغة الإنجليزية على

" The Member States should:

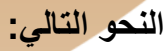

1) provide consumer associations with adequate financial support, enabling them to carry out their duty to protect the rights of all consumers. The possibility of creating a fund using the amount of 


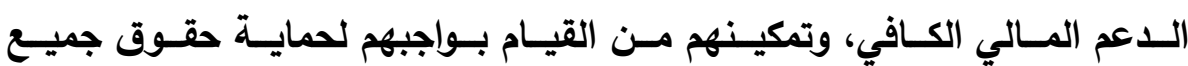

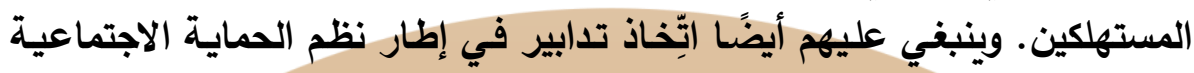

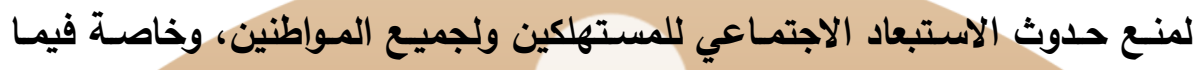
يتعلق بالحصول على وتوريد الخدمات الضرورية والأساسية.

وللتخفيف من آثار الأزمـة، فإن اللجنة الاقتصـادية والاجتماعية الأوروبية

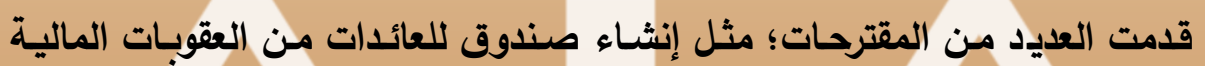

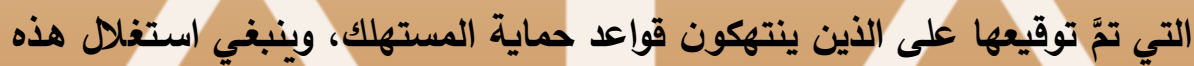

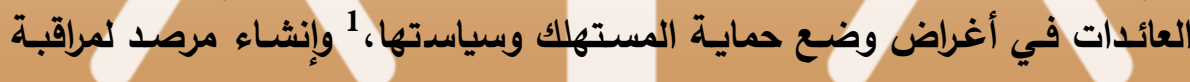

the penalties imposed in consumer issues for the development and implementation of policies for consumer protection, and in particular the implementation of measures of general interest of benefit to all consumers, should be examined on the basis of the experience of Member States where such funds already exist, with a view to then setting one up and operating it, in accordance with the legislation of each Member State;

2) adopt measures within their social protection systems to prevent the social exclusion of consumers and of all citizens, above the $\mathbf{3 0}$ $\%$ mentioned in the Multidimensional Poverty Index, especially as regards access to and supply of basic essential services. Each Member State would, in accordance with its requirements, contribute to this end by preparing and implementing a 'citizens' rescue plan' which would help to relaunch household economies and consumer purchasing power."

1 انظر الفقرة الخامسة من البند رقم 4 من رأي اللجنة التي يجري نصها باللغة الإنجليزية على

"Firstly, a fund should be created with the proceeds from the financial penalties imposed on those who breach consumer rules, and these sums should be used for consumer protection policy purposes, in particular for measures of general interest, by means of the instrument of collective action, of benefit to the entire population, carried out by consumer associations and public authorities and other bodies able to take action to enforce this policy, in keeping with the provisions of each Member State." 
مجلة القانون والاقتصاد - ملحق خاص بمناسبة مرور مائة وخمسين عام

على إنشاء كلية الحقوق - جامعة القاهرة - العدد (الثانى والتسعون)

السياسات الإستراتيجية المعتمدة في القطاعات الحيويـة، مثل خدمات تلقى اهتمامًا

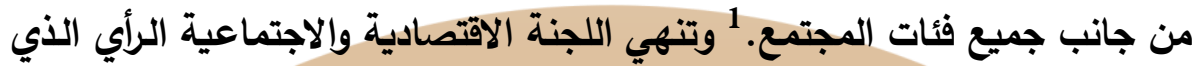

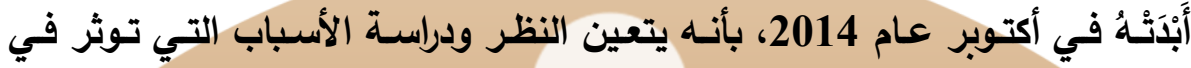
إبداء المستهلك لموافقته في عقود الاستهلاك، وأيضًا إلى الممارسـات التي تشـوره

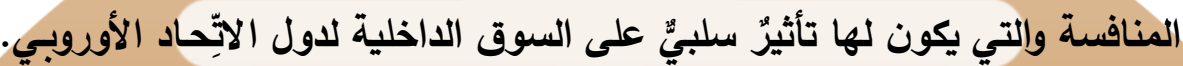

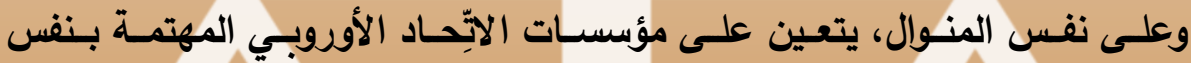

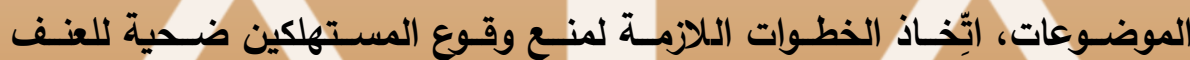

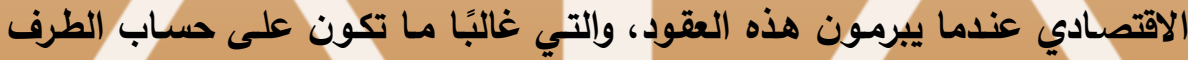
| الضعيف.
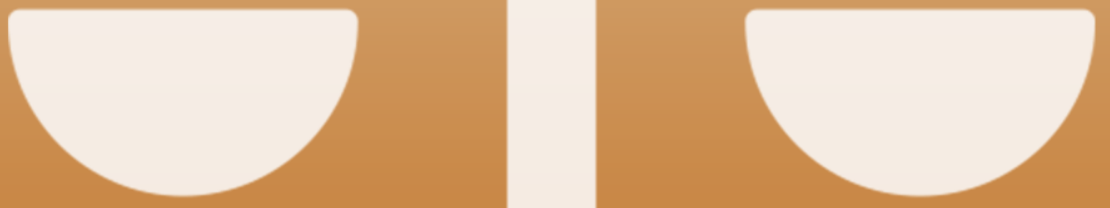

1 انظر الفقرة التاسعة من البند رقم 4 من رأي اللجنة التي يجري نصها باللغة الإنجليزيـة على “Similarly, a basic preventive measure would be set to set up an observatory to monitor strategic policies adopted in critical sectors such as services of general interest, audiovisual services, fuels, banking, energy oligopolies, housing, etc., which may represent a risk to which weaker consumers are more vulnerable." 2 انظر الفقرة التاسعة عشرة من البند رقم 4 من رأي اللجنة التي يجري نصها باللغة الإنجليزية

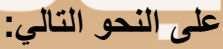

"The EESC should give consideration to this flaw affecting consumer consent to contracts, and to the distortion of competition that it causes in the internal market. The other $\mathrm{EU}$ institutions should give it proper attention, taking the necessary steps to prevent consumers falling victim to economic violence when they enter into contracts, on account of their weaker position." 


\section{الغاتمةمة}

تُعَدُ هذه الدراسدة التحليلية للقواعد القانونيـة المتعلقـة بالممارسـات التجاريـة

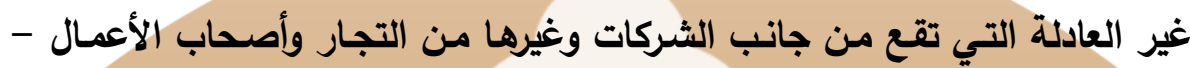

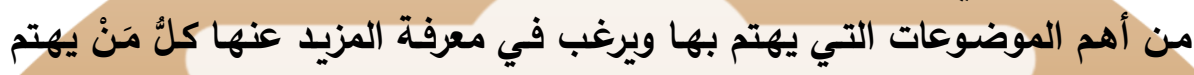
بحماية المستهلك. ومن ثم فقد قمنا باراسة القواعد التي تضمنها التوجيه الأوروبي مئي المتعلق بالممارسات التجارية غير العادلة رقم 29 لسدنة 2005 والتطورات اللاحقة لـانة

وترجيح أهمية القواعد التي يشملها التوجيه إلى ضرورة الحدّ، بـل القضاء التهاء

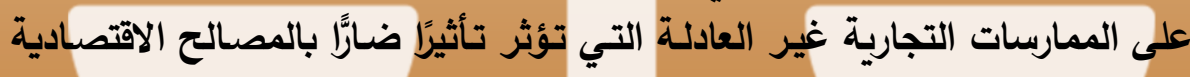

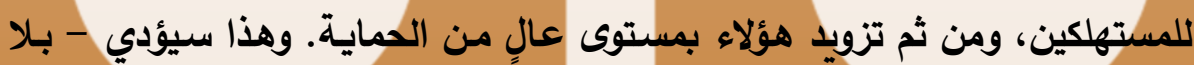

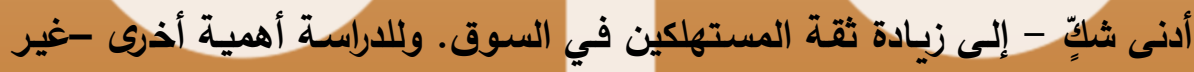

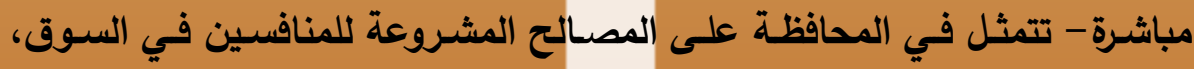

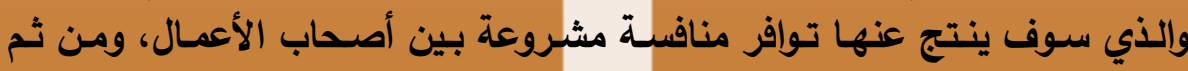

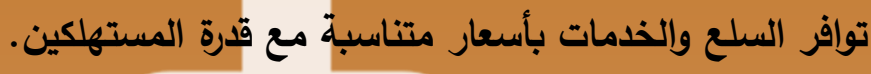

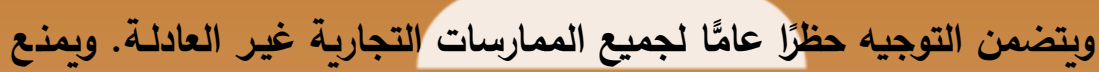

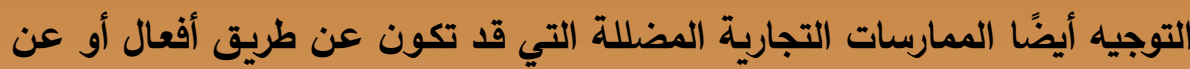

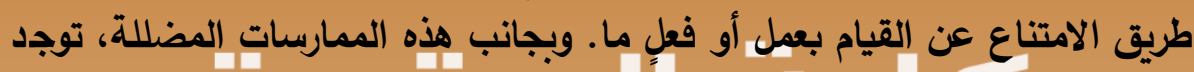

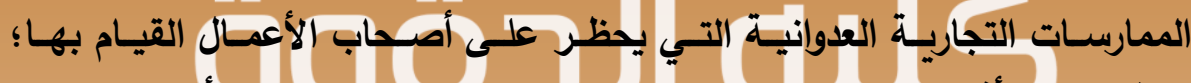

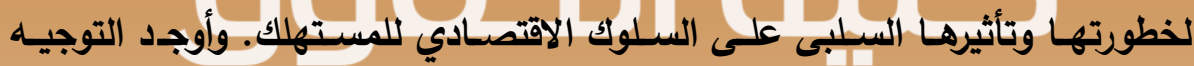

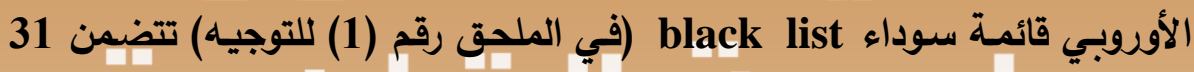

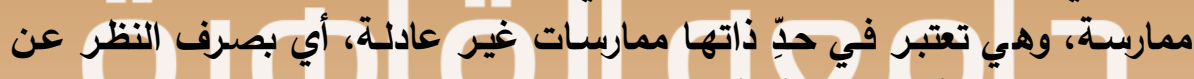

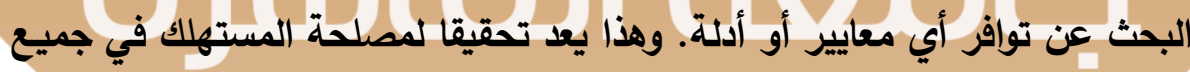

الاحوال.

ووفقًا لأحكام التوجيه، يشترط لانطباق الحظر العام وصف الممارسـة المعنية

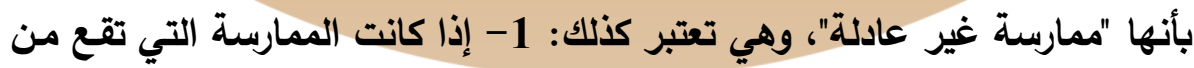

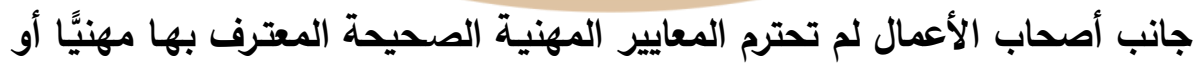


مجلة القانون والاقتصاد - ملحق خاص بمناسبة مرور مائة وخمسين عام

على إنشاء كلية الحقوق - جامعة القاهرة - العدد (الثانى والتسعون)

بواسـطة العـرف في مجـال معين (معيـار "واجب الحيطـة المهنيـة")، و2- تـؤثر

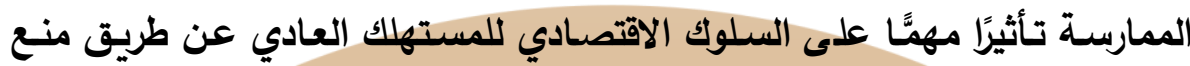

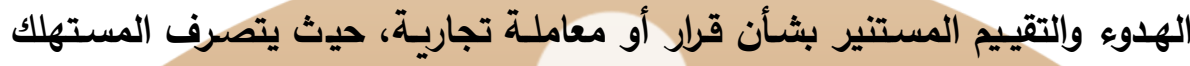

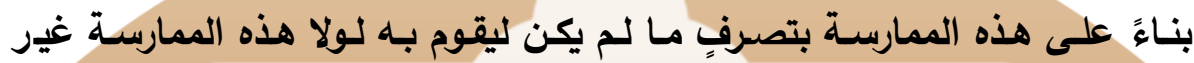

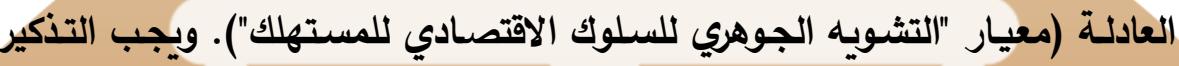

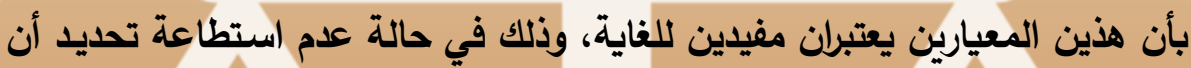
ممارسة ما "مضلاتة" أو "عدوانية".

وفيما يتعلق بالممارسات التجاريـة المضللة فقد اشتمل التوجيه على نوعين

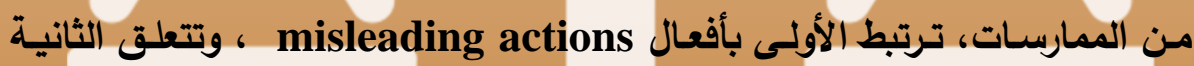

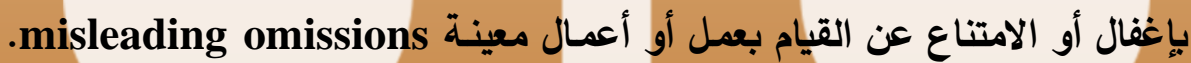

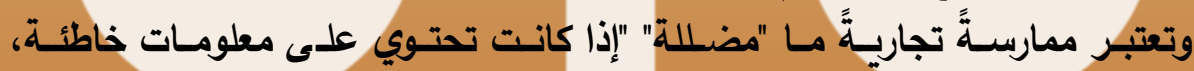

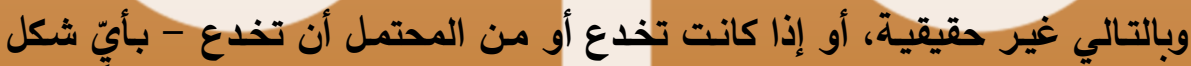

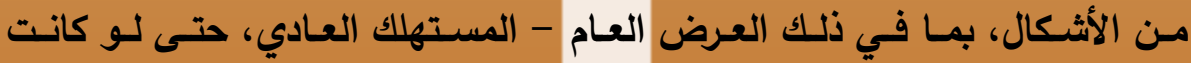

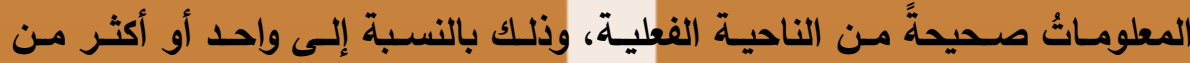

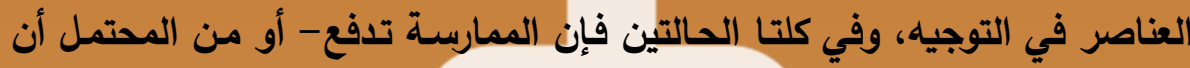

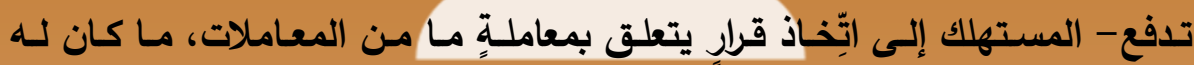

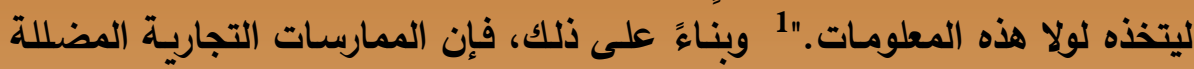

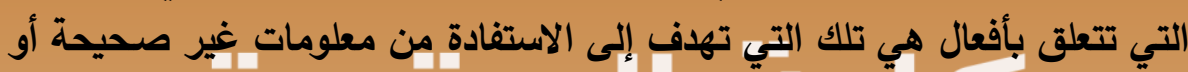

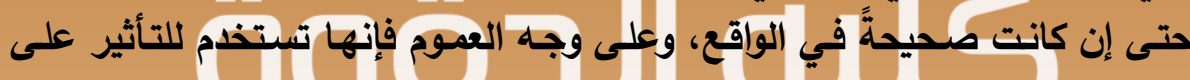

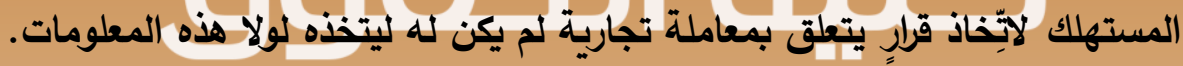

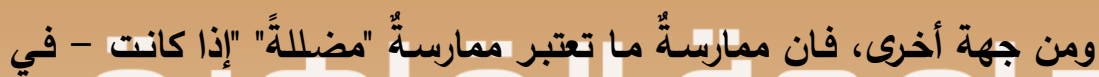

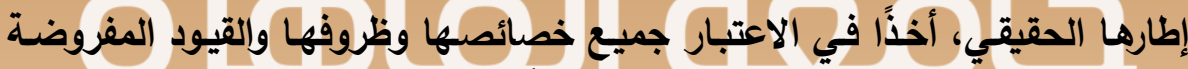

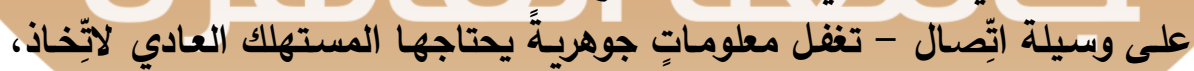

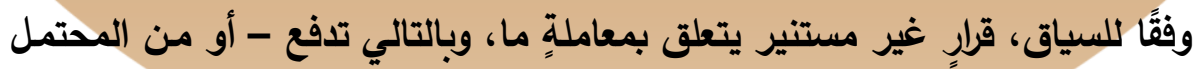

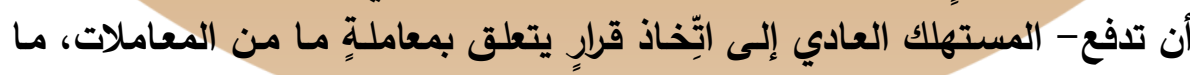


وقد تقع الممارسات التجاريـة "المضللة" عن طريق إخفاء معلومـات جوهريـة

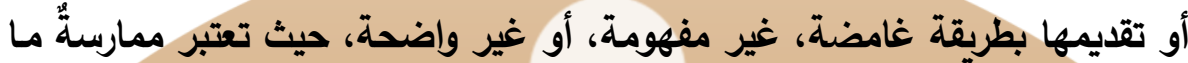

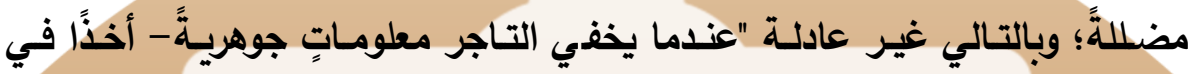

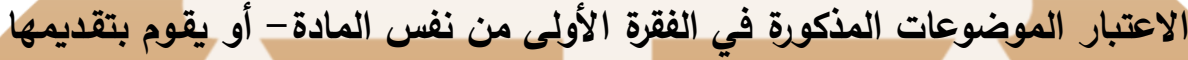

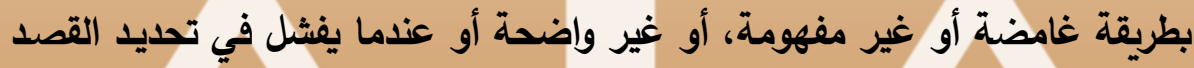

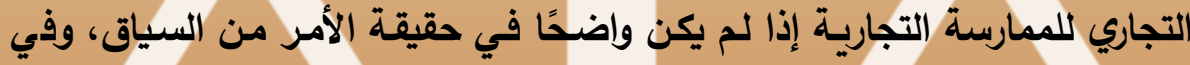

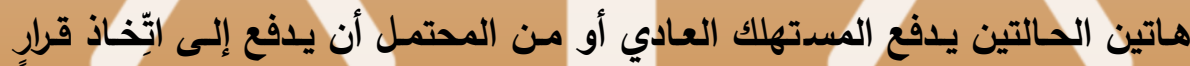

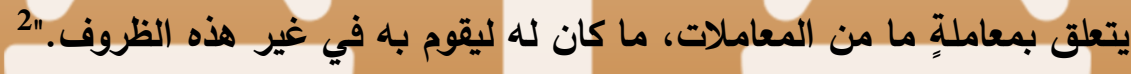
وتعتبر ممارسة ما كونها "عدوانية"، عندما - ناظرًا إلى إطارها الفعلي وأخذًا

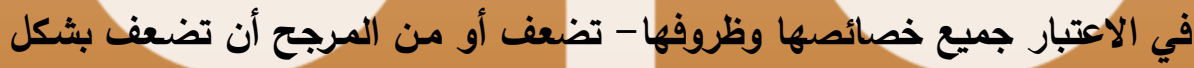

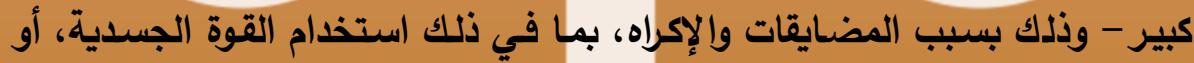

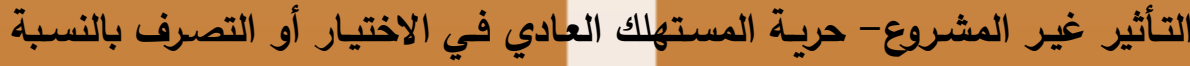

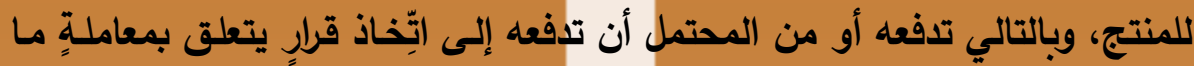

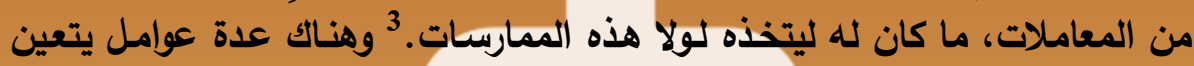

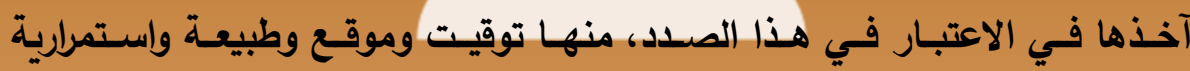

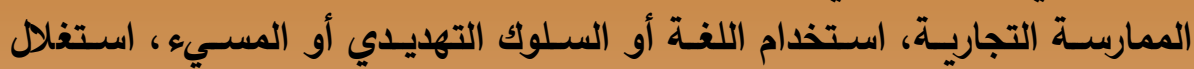

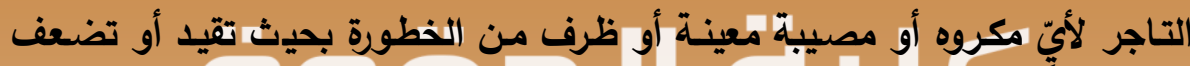

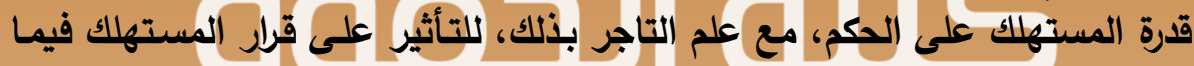

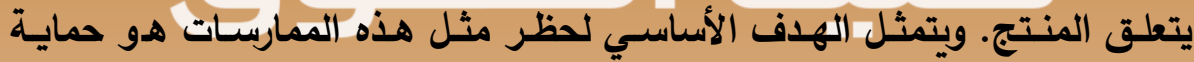

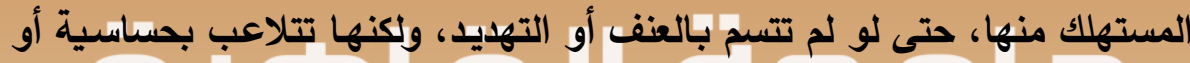
عواطف أو ظروف أو الحالـة الذهية للمستهلك، مما يؤثر على قدرة المستهلك على اتِّاذ القرارات المناسبة لله في يقظة ووعي كامل.

1 انظر الفقرة الأولى من المادة السابعة من التوجيه. 2 الفقرة الثانية من المادة السابعة من التوجية التئه 3 
مجلة القانون والاقتصاد - ملحق خاص بمناسبة مرور مائة وخمسين عام

على إنشاء كلية الحقوق - جامعة القاهرة - العدد (الثانى والتسعون)

ويحمي توجيه الممارسـات التجاريـة غير العادلة المستهلك من الممارسـات

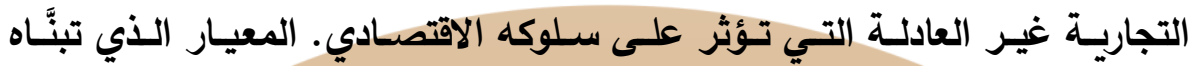

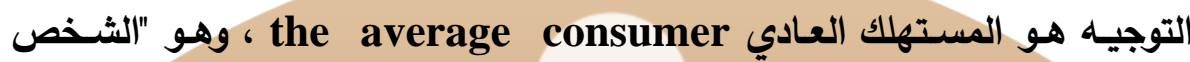

المستنير الذي لايه قرر معقول من اليقظة وإلحرص"، ولكن في نفس الوقت، اهتمَّ

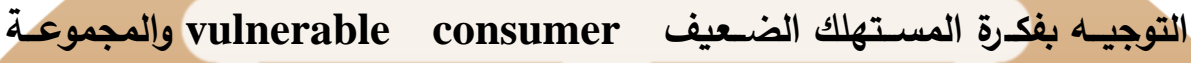

المستهدفة targeted group ، حيث حث على بـ حمايتهما.

وتجدر الإثارة إلى أن توجيه الممارسات التجارية غير العادلة دعا إلى تبنِي

مدونات قواعد السلوك Codes of Conduct بطريقة غير مباشرة.

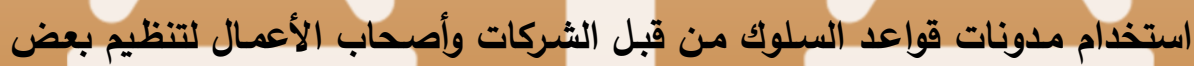

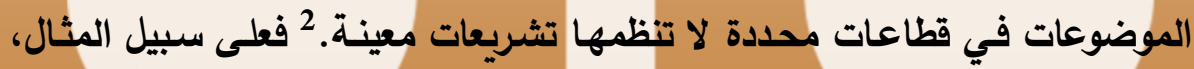

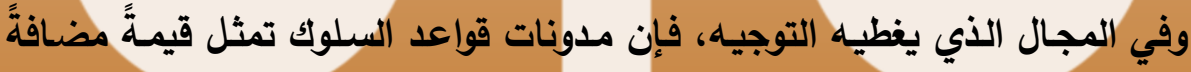
من خلال تنفيذ مبادئ التوجيه في القطاعات ذات الصلة.

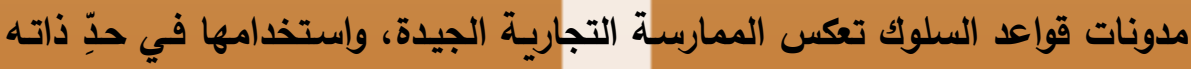

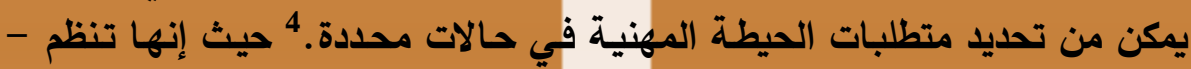

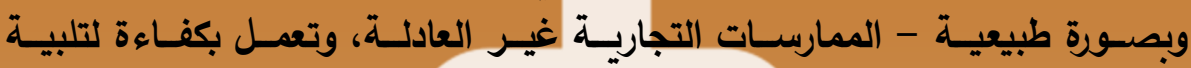

$$
1 \text { ويجري نص المادة العاثرة باللغة الإنجليزية على النحو التالي: }
$$

"1- This Directive does not exclude the control, which Member States may encourage, of unfair commercial practices by code owners and recourse to such bodies by the persons or organisations referred to in Article 11 if proceedings before such bodies are in addition to the court or administrative proceedings referred to in that Article.

2- Recourse to such control bodies shall never be deemed the equivalent of foregoing a means of judicial or administrative recourse as provided for in Article 11."

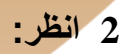

Abbamonte, op. cit., p. 710 and Poncibo and Incardona, op. cit., p.

324.

Abbamonte, op. cit., p. 710.

: 3

4 

التجارية غير العادلة رقم 29 لسنة 2005 والتطورات التشريعية التلاحقة

احتياجات رجال الأعمال والمستهلكين بصورة أكثر سرعةً وأكثر مرونـةً من القوانين

الوطنية.

وهناك حكم مهم وارد في التوجيه له صلة بمدونات قواعد السلوك؛ هو نص الهـ

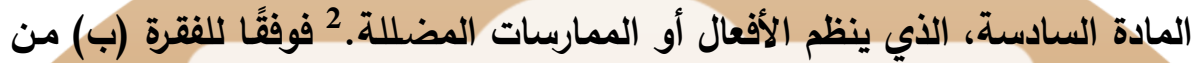

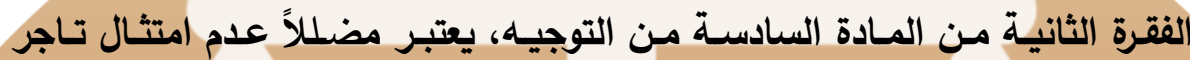

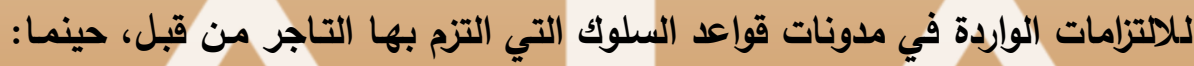

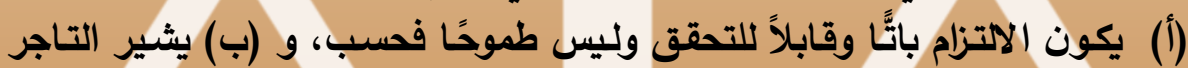
في الممارسة التجارية إلى أنه ملتزم بالقواعد الواردة في مدونة التولة السلوك. 3 وبعد هذا العرض لأهم الموضوعات والنتائج التي تتاولتها وتوصلت إليها هذه الاراسة، فإنها توصي بما يأتي: 4

- تسهيل إجراءات التقاضي عن طريق اعتماد إجراءات خاصة تكون متوافرة

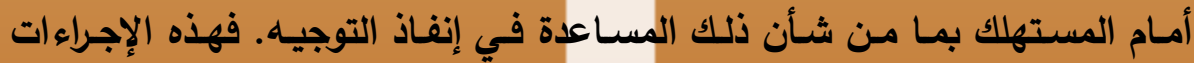

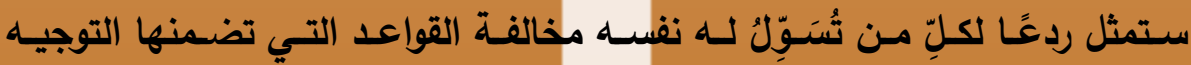

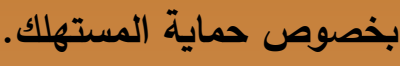
- تقديم الدعم المالي الكافي لجمعيات حماية المستهلك وتمكينهم من القيام

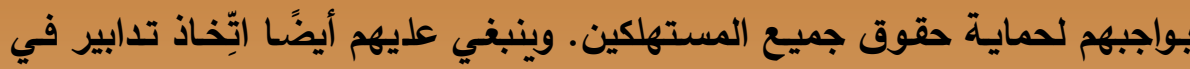

Poncibo and Incardona, op. cit., p. 324.

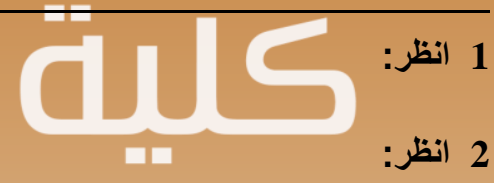

Abbamonte, op. cit., pp. 710-711.

3 ويجري نص هذه الفقرة باللغة الإنجليزية على النحو التالي: "non-compliance by the trader with commitments contained in codes of conduct by which the trader has undertaken to be bound, where: (i) the commitment is not aspirational but is firm and is capable of being verified, and (ii) the trader indicates in a commercial practice that he is bound by the code."

Vaque, op. cit., p. 219 et seq. 
مجلة القانون والاقتصاد - ملحق خاص بمناسبة مرور مائة وخمسين عام

على إنشاء كلية الحقوق - جامعة القاهرة - العدد (الثانى والتسعون)

إطـار نظم الحمايـة الاجتماعيـة؛ لمنـع حدوث الاسـتبعاد الاجتمـــي للمستهلكين

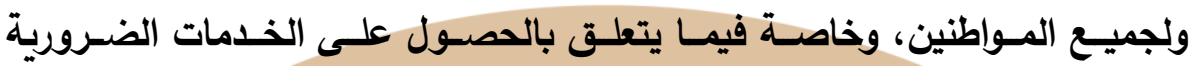

والأساسية.

- إنشاء صندوق للعائدات من العقوبات المالية التي يتم توقيعها على الذين

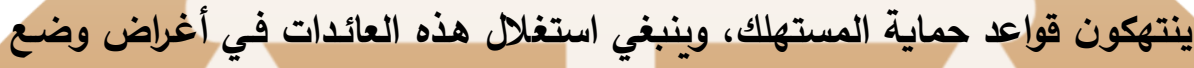

حماية المستهلك وسياستها.

- يتعين النظر في دراسـة الأسباب التي توثر في إبداء المستهلك لموافقته إفها

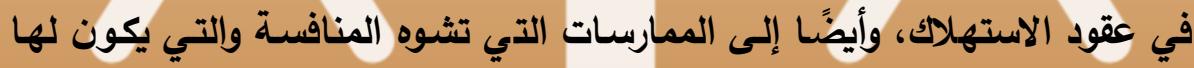

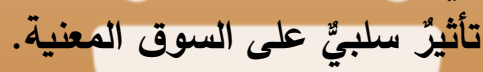

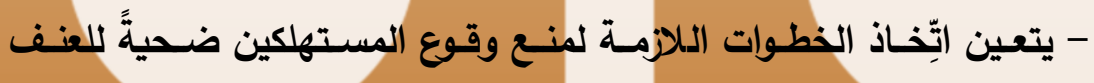

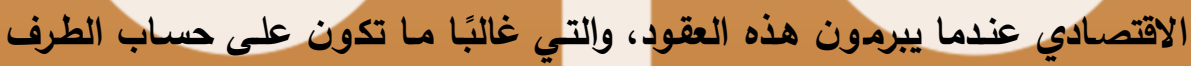
| الضعيف.

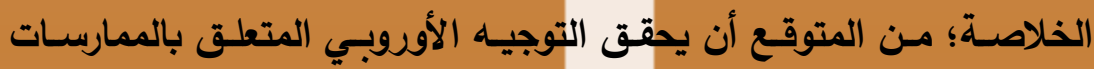

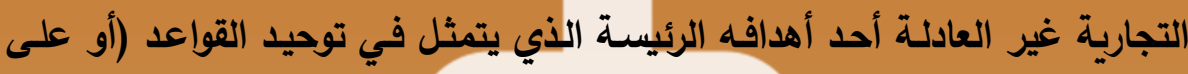

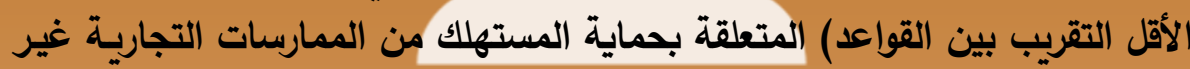

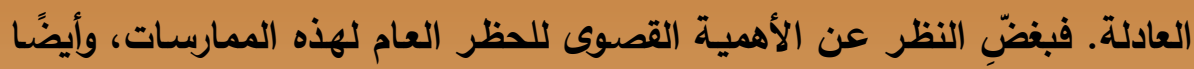

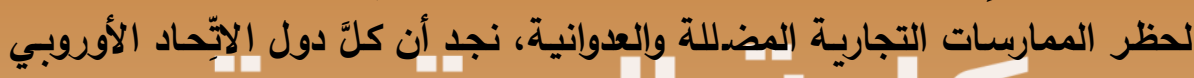

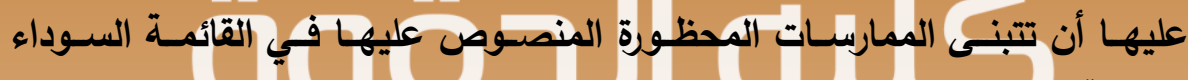
الملحقة بالتوجيه.

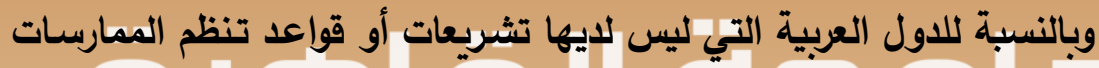

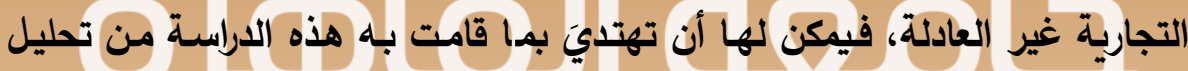

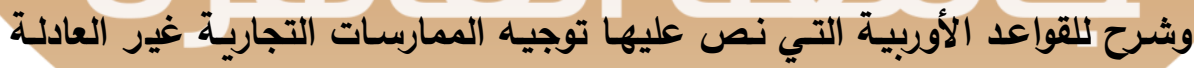

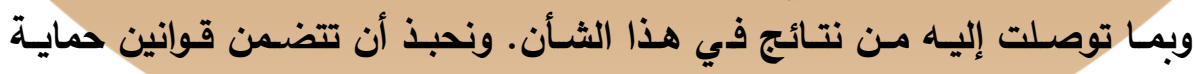

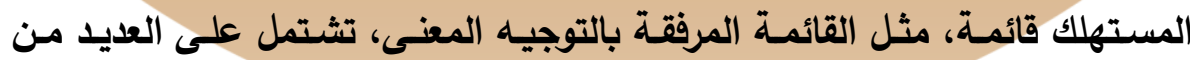

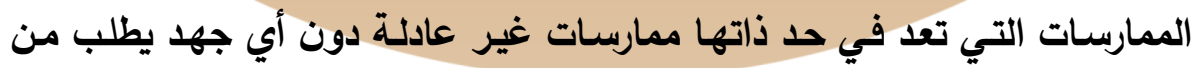
جانب المستهلك لإثبات أنها ممارسات غير دير عادلة أو لإثبات اصابته بضرات عادر دا. 
إن وجود قواعد توفر حماية للمستهلك ضد الممارسـات التجاربـة غير العادلة

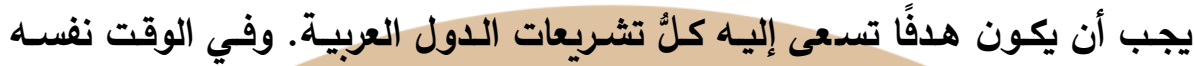

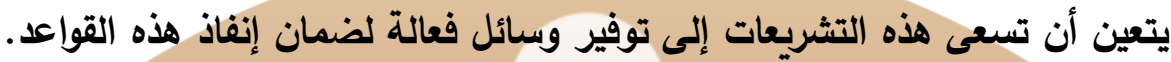

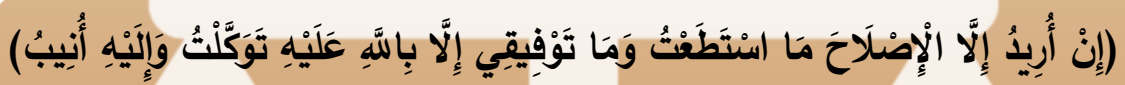
من الآية: 88، سورة هود.

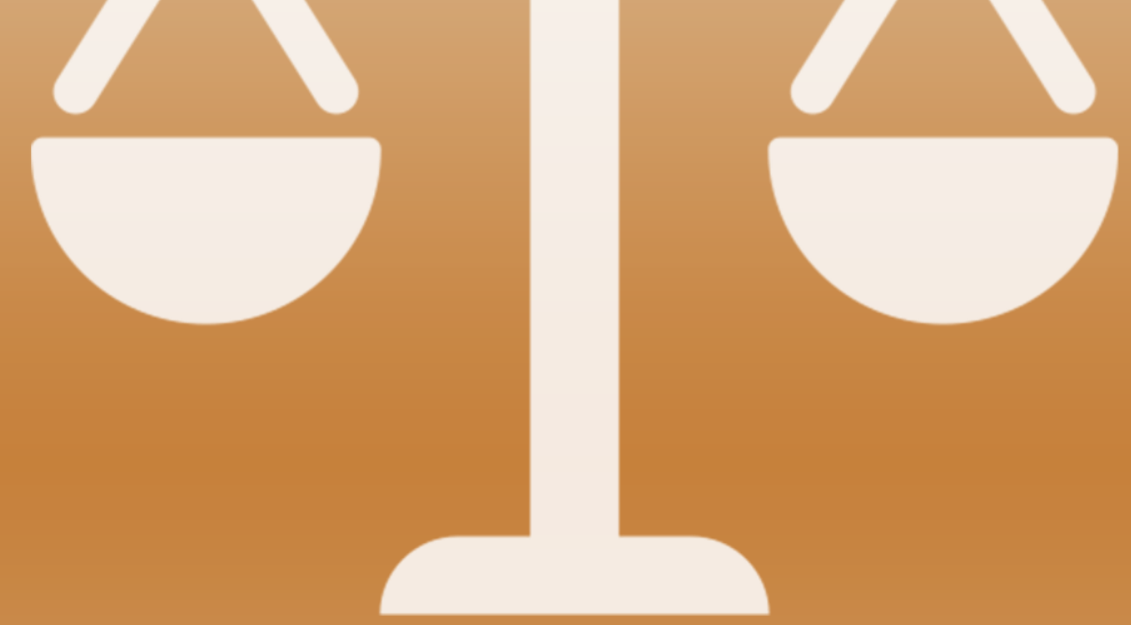

\section{كلية الحقوق} جامعة القاهرة الحقوق 
مجلة القانون والاقتصاد - ملحق خاص بمناسبة مرور مائة وخمسين عام

على إنثاء كلية الحقوق - جامعة القاهرة - العدد (الثانى والتسعون)

\section{المراجع}

أولا: الكتب والابماث بالاغة الإمبهيرة Books and Articles :

1. Anna

G.

Ciancio, ${ }^{6}$ The

Unfair Commercial Practices Directive and the UK Consu mer Protection from Unfair Trading Regulations: A Possible Conceptual Convergence of General, Flexible European Standards and English Law Concepts Relevant to Fairness in the EU Context of Consumer Protection.' Available at: http://papers.ssrn.com/sol3/papers.cfm?abstract_id=10993 09.

2. Avishalom Tor, 'Some Challenges Facing A Behaviorally Informed Approach To the Directive on Unfair Commercial Practices' in Tihamer Toth, Unfair Commercial Practices: The Long Road to Harmonized Law Enforcement (Budapest: Pazmany Press, 2013).

3. B. B. Duivenvoorde, The Consumer Benchmarks in the Unfair Commercial Practices Directive (Switzerland: Springer International Publishing, 2015).

4. Bert Keirsbilck, The New European Law of Unfair Commercial Practices and Competition Law (Oxford: Hart Publishing, 2011).

5. C.M.D.S. Pavillon, 'The Interplay Between The Unfair Commercial Practices Directive and Codes of Conduct' (2012) 5 (4) Erasmus Law Review, pp. 267-288.

6. Cristina Poncibo and Rossella Incardona, 'The Unfair 
نحو حمايـة فعالـة للمستهلك طبقا للتوجيه الأوروبي المتعلق بالممارسـات التجارية غير العادلة رقم 29 لسنة 2005 والتطورات التشريعية التلاحقة

Commercial Practices Directive: A Faltering First Step' (2005) 1(2) London Law Review, pp. 317-337.

7. Giuseppe B. Abbamonte, 'The Unfair Commercial Practices Directive: An Example of the New European Consumer Protection Approach'(2006) 12 Columbia Journal of European Law, pp.695-712.

8. H.W. Micklitz, 'Unfair Commercial Practices and Misleading Advertising' in Hans-W. Micklitz, Norbert Reich and Peter Rott, Understanding EU Consumer Law (Oxford: Intersentia, 2009).

9. Hans-W. Micklitz, Norbert Reich and Peter Rott, Understanding EU Consumer Law (Oxford: Intersentia, 2009).

10. Hugh Collins, 'Harmonisation by Example: European Law against Unfair Commercial Practices' (2010) 73 Modern Law Review, pp. 89-118.

11. Luis Gonzales Vaque, 'Directive 2005/29/EC on Unfair Commercial Practices and Its Application to Food-Related Consumer Protection' (2015) 3 European Food and Feed Law Review, pp.210-221.

12. Marios Koutsias and Chris Willett, 'The Unfair Commercial Practices Directive in the UK' (2012) 5 (4) Erasmus Law Review, pp.237-251.

13. Mateja Djurovic, European Law on Unfair Commercial Practices and Contract Law (The UK: Bloomsbury Publishing Plc, 2016).

14. Matthias Leistner, 'Unfair Competition or Consumer 
مجلة القانون والاقتصاد - ملحق خاص بمناسبة مرور مائة وخمسين عام

على إنشاء كلية الحقوق - جامعة القاهرة - العدد (الثانى والتسعون)

Protection? The Commission's Unfair Commercial Practices Proposal 2003' (2003-2004) 6 Cambridge Y.B. Eur. Legal Stud. P. 141.

15. Nathan Reilly, 'The Role of Traders in the Enforcement of the Unfair Commercial Practices Directive: A New Unfair Competition Law for Ireland' (2009) 31 Dublin University Law Journal, pp. 100-126.

16. Rossella Incardona and Cristina Poncibo, 'The Average Consumer, the Unfair Commercial Practices Directive, and the Cognitive Revolution' (2007) 30 (1) Journal of Consumer Policy, pp. 21-38.

17.S Haupt, 'An Economic Analysis of Consumer Protection Law', (2003) 11 German Law Journal.

18. S Weatherill and U Bernitz, The Regulation of Unfair Commercial Practices under EC Directive 2005/29: New Rules and New Techniques (Oxford: Hart Publishing, 2007).

19. T Wilhelmsson, 'The Abuse of the 'Confident Consumer' as a Justification for EC Consumer Law' (2004) 27 (3) Journal of Consumer Policy, pp. 317-337.

20. The European Commission: The Unfair Commercial Practices Directive: New Laws to Stop Unfair Behavious Towards Consumers (European Commission: Office for Official Publications of the European Communities, 2006).

21. Thomas Wilhelmsson, 'Harmonizing Unfair Commercial Practices Law: The Cultural and Social Dimensions' (2006) 44 (3) Osgoode Hall Law Journal, pp. 461-500. 
نحو حمايـة فعالـة للمستهلك طبقا للتوجيه الأوروبي المتعلق بالممارسـات التجارية غير العادلة رقم 29 لسنة 2005 والتطورات التشريعية التلاحقة

22. Tihamer Toth, Unfair Commercial Practices: The Long Road to Harmonized Law Enforcement (Budapest: Pazmany Press, 2013).

23. Timothy J. Muris, 'The Interface of Competition and Consumer Protection' (Prepared Remarks at the Fordham Corporate Law Institute's 29th Annual Conference on International Antitrust Law and Policy, New York City, Oct. 31, 2002).

24. U Bernitz, 'The Unfair Commercial Practices Directive: Its Scope, Ambitions and Relation to the Law of Unfair Competition' in S Weatherill and $U$ Bernitz, The Regulation of Unfair Commercial Practices under EC Directive 2005/29: New Rules and New Techniques (Oxford: Hart Publishing, 2007).

25. Vanessa Mak, 'Standards of Protection: In Search of the 'Average Consumer' of EU Law in the Proposal for a Consumer Rights Directive.' A working paper available at: http://papers.ssrn.com/sol3/papers.cfm?abstract_id=16261 15.

26. Willem H. Van Boom, Amandine Garde and Orkun Akseli, 'Introduction' in Willem H. Van Boom, Amandine Garde and Orkun Akseli, The European Unfair Commercial Practices Directive: Impact, Enforcement Strategies and National Legal Systems (The UK: Routledge Publishing, 2016).

27. Willem H. Van Boom, Amandine Garde and Orkun Akseli, The European Unfair Commercial Practices Directive: 
مجلة القانون والاقتصاد - ملحق خاص بمناسبة مرور مائة وخمسين عام

على إنشاء كلية الحقوق - جامعة القاهرة - العدد (الثانى والتسعون)

Impact, Enforcement Strategies and National Legal Systems (The UK: Routledge Publishing, 2016).

\section{: Oانيا: المستند/ت الرسمية Official Documents}

1. Commission Green Paper on European Union Consumer Protection, COM (200 I) 531 final (Brussels, October 2, 2001).

2. Council Directive 84/450, art. 1(2), 1984 O.J. (L 250) 17 (EEC), as amended by Council Directive 97/55, 1997 O.J. (L 290) 18 (EC).

3. Directive 2005/29/EC of the European Parliament and of the Council of 11 May 2005 concerning unfair business-toconsumer commercial practices in the internal market and amending Council Directive 84/450/EEC, Directives 97/7/EC, 98/27/EC and 2002/65/EC of the European Parliament and of the Council and Regulation (EC) No 2006/2004 of the European Parliament and of the Council ('Unfair Commercial Practices Directive').

4. European Commission: "First Report on the application of Directive zoos/29/EC of the European Parliament and of the Council of 11 May 2005 concerning unfair businessto-consumer commercial practices in the internal market[ ... and amending Council Directive 84/450/EEC, Directives 97/7/EC, 98/27/EC and 2002/65/EC of the European Parliament and of the Council and Regulation (EC) No 2006/2004 of the European Parliament and of the Council ('Unfair Commercial Practices Directive')." Brussels, 14.3.2013 COM(2013) 139 final." 
نحو حمايـة فعالـة للمستهلك طبقـا للتوجيه الأوروبـي المتعلق بالممارسـات التجارية غير العادلة رقم 29 لسنة 2005 والتطورات التشريعية التلاحقة

5. European Commission: "The Communication of the Commission itself to the European Parliament, the Council and the European Economic and Social Committee of 2013 on the application of the Unfair Commercial Practices Directive "Achieving a high level of consumer protection Building trust in the Internal Market." Brussels, 14.3.2013 $\operatorname{COM}(2013) 139$ final.

6. European Commission: Guidance on the Implementation/Application of Directive zoos/29/EC on Unfair Commercial practices. Brussels, 3 December 2009 SEC(2009) 1666.

7. The European Parliament 'the European Parliament Resolution of 4 February 2014 on the implementation of the Unfair Commercial Practices Directive 2005/29/EC. " Strasbourg, [2013/2116 (INI)].

8. The Opinion of the European Economic and Social Committee on Consumer vulnerability in business practices in the single market (Own-initiative opinion) 15 October 2014 (Official Journal) C12, 15 October 2015. 
530

على إنثاء كلية الحقوق - جامعة القاهرة - العدد (الثانى والتسعون)

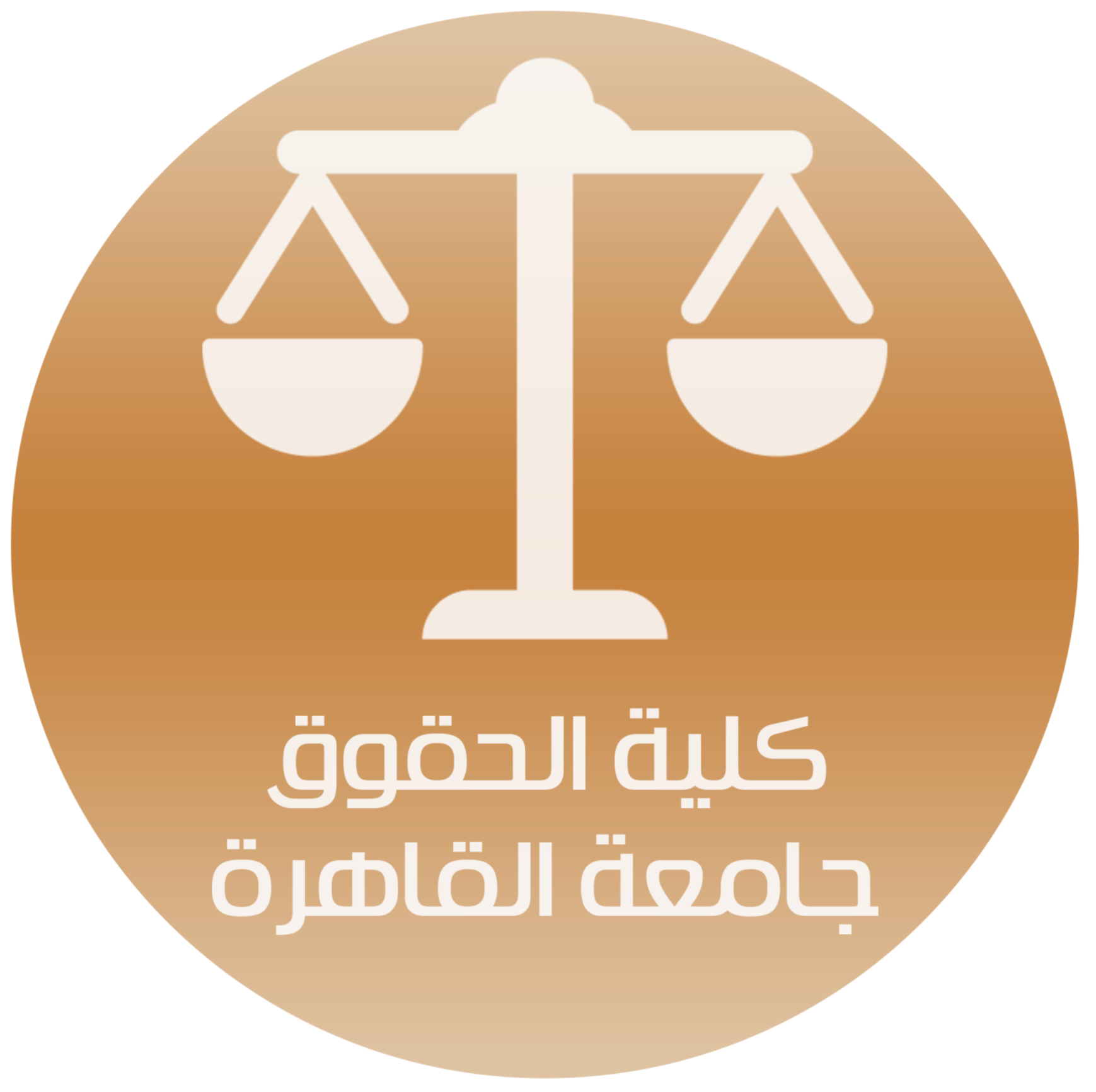

